Historic, Archive Document

Do not assume content reflects current scientific knowledge, policies, or practices. 



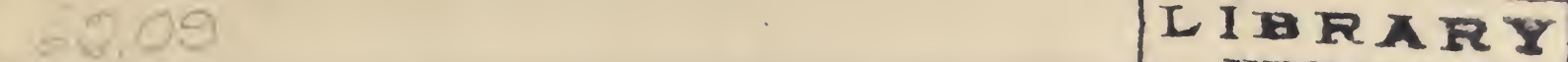

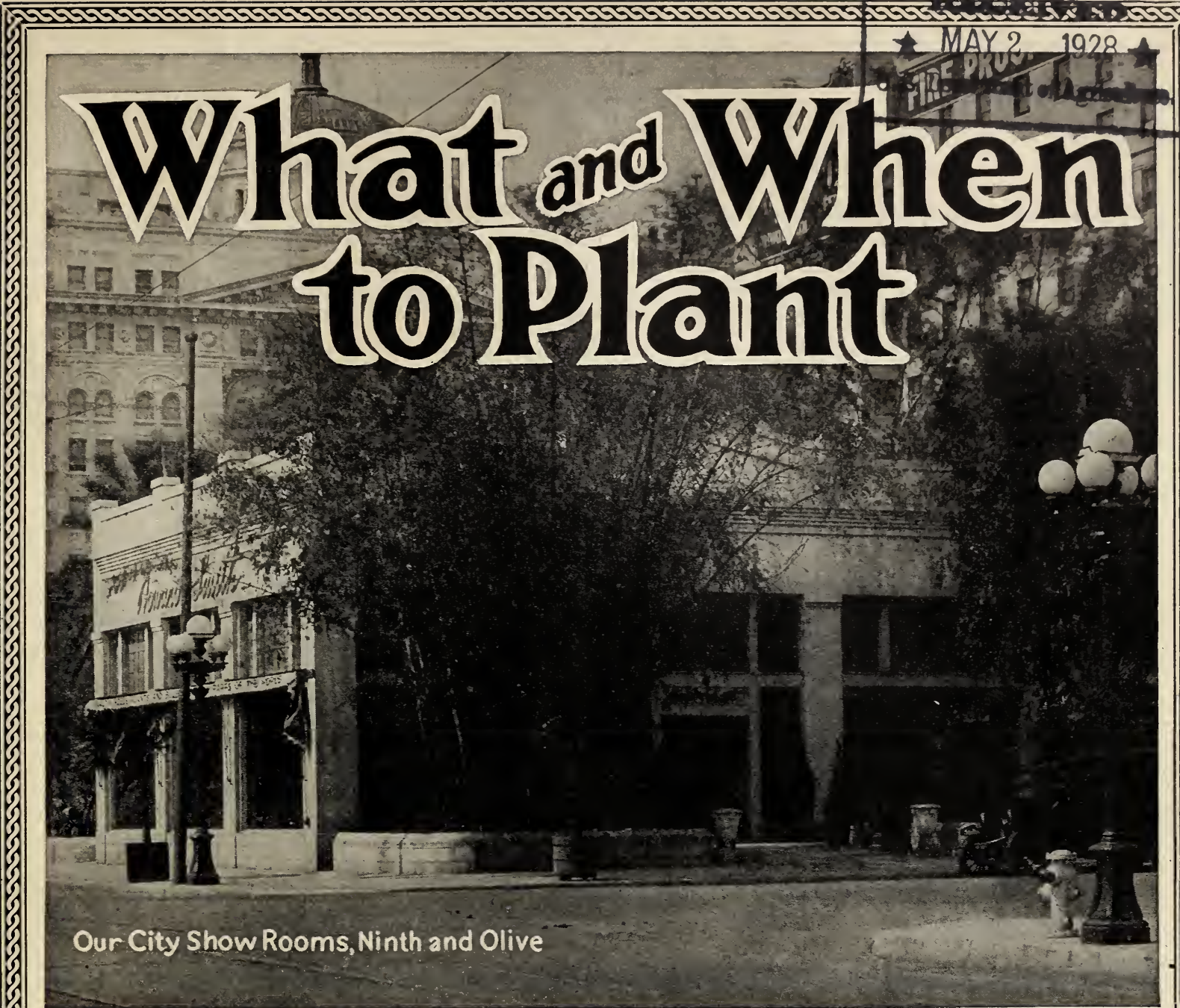

SPRING and SUMMER

SEASON of 1928

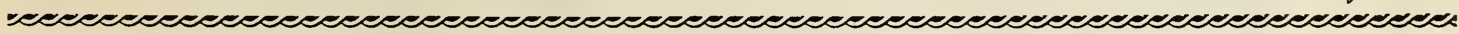

कात्न E TAKE PLEASURE in presenting you with our bulletin for the Spring and Sum(1) mer season of 1928. You will find incorporated in the following pages a collection f 1 of plants, bulbs and seeds which we believe in point of quality is second to none.

The year of 1927 was a particularly favorable one for plant growth. Bountiful Q Spring rains and a moderately warm Summer and Autumn were conducive to the production of sturdy plants and seeds of splendid viability. Our strains of Asters, Zinnias and other flower seeds for which our firm is famous were never better.

If you are a lover of gardening, a perusal of these pages is sure to disclose certain items which will interest you and which will undoubtedly add to the attractiveness of your garden.

\section{NOW IS THE TIME TO PLANT}

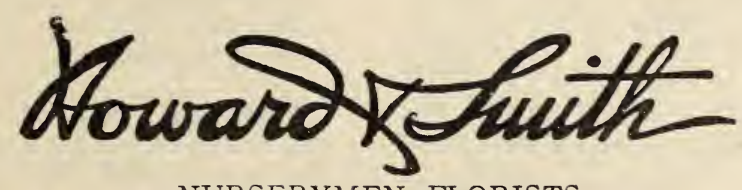

Station C

Postoffice BoX 484
NURSERYMEN, FLORISTS

LANDSCAPE ARCHITECTS
Olive Street at Ninth Los ANgeles, U. S. A. 


\section{NOVELTIES and SPECIALTIES for 1928}

\section{A SUPERB SET OF NEW CARNATIONS}

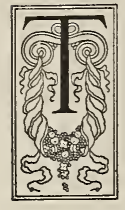

HE FOLLOWING new Carnations are exceedingly fine. They represent the last word in the improvement of this popular class of flower. They are of remarkable size and of splendid form and contour. We have grown all these varieties outside and find that they do well treated as an open garden subject. In this locality they produce splendid crops of flowers during that period of the year when blooms are usually scarce, i. e., mid-winter.

If extra large flowers are desired, dis-budding may be resorted to, and if treated in this manner they will be of phenomenal size. They are all good growers, exceedingly fragrant and free in the production of blooms. A bed of these in your garden will give you flowers of splendid quality for mid-winter and spring cutting.

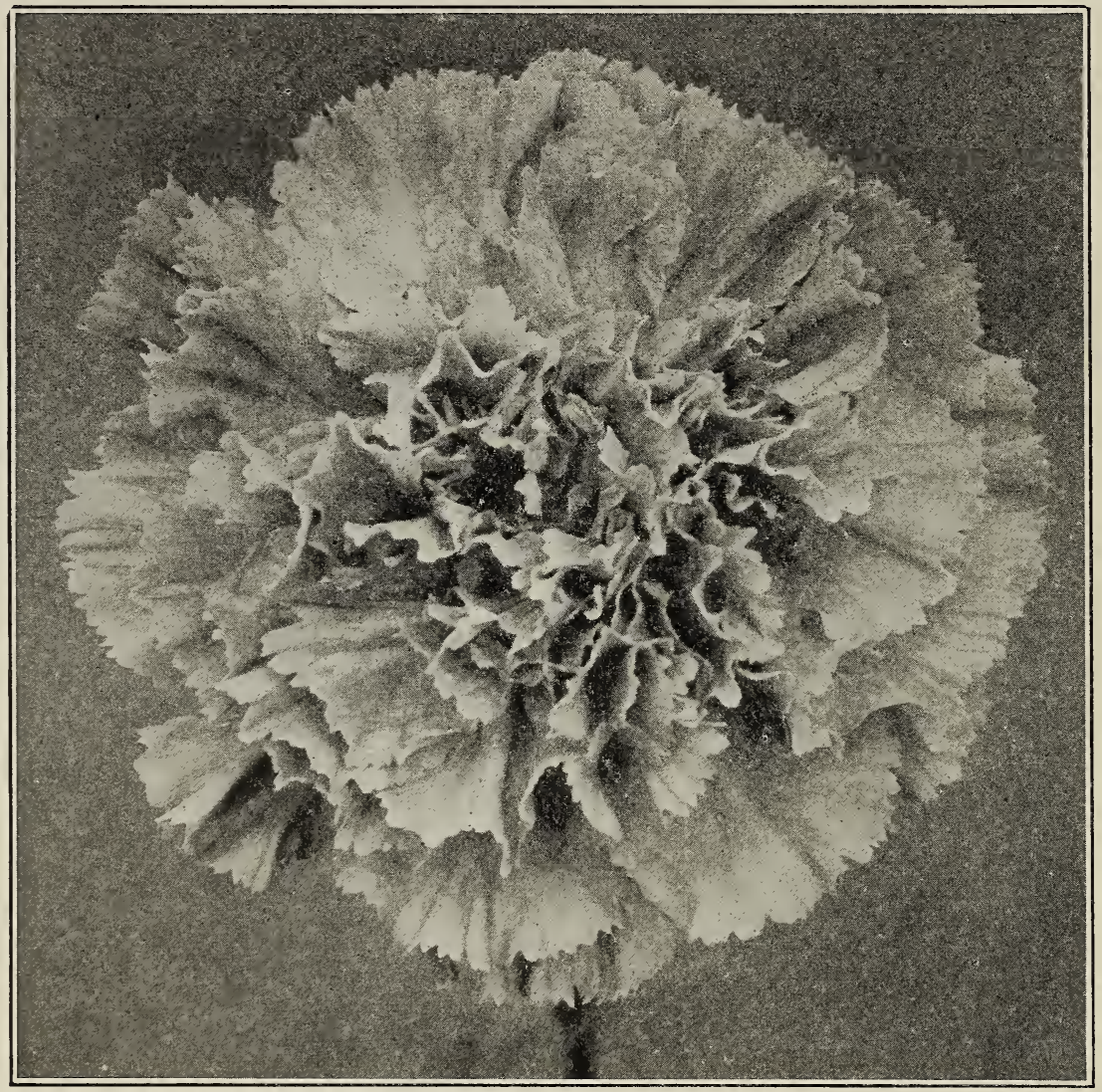

ARCTIC. Pure white; of phenomenal size and substance. Intensely fragrant.

Price each, 20c; per doz., $\$ 2.00$.

BETTY LOU. About the same color as Mrs. C. W. Ward. Deep rich rose flowers, beautifully ruffled and fringed. Calyx perfect. Stems of great length. Very fine.

Price each, 20c; per doz., \$2.00.

ELDORA. A fine variegated variety. Ground color of pure white, daintily penciled with scarlet. A strong, quick grower and produces a bountiful supply of fine, perfect blooms.

Price each, 20c; per doz., \$2.00.

EDNA. A lovely, free flowering, pure rich scarlet and a continuous bloomer. Plant of compact growth and splendid long stemmed flowers.

Price each, 20c; per doz., $\$ \mathbf{2 . 0 0}$.

JEWEL. One of the daintiest of all light colored Carnations, being a shade of pure shell pink; petals deepiy fringed. A well built flower of magnificent proportions.
Price each, 20c; per doz., $\$ 2.00$.
ROYAL. A splendid shade of bright purple. Blossoms exceedingly large and of an unique color.

Price each, 20c; per doz., \$2.00.

SUPER SUPREME. A sport from the well known variety Enchantress, but a deeper and richer tone of beautiful light pink. Like the parent, the flowers are of immense size, with perfect calyx. Good stems; deliciously fragrant. $\quad$ Price each, 20c; per doz., \$2.00.

WINSOME. A pleasing shade of medium pink. The plants are floriferous to a degree. producing an abundance of splendid flowers over a long period.

Price each, 20c; per doz., $\$ \mathbf{2 . 0 0}$.

YANKEE GIRL. A very productive variety in a pleasing shade of light rose pink. It blooms freely, always fine in color, and although very large in size, it does not split its calyx.

Price each, 20c; per doz., \$2.00.

BREAK O'DAY. A lovely, free blooming shell pink. Deeply fringed petals and a flower of perfect form and substance. A splendid addition to the light colored class.

Price each, 20c; per doz., $\$ 200$. 
MAINE SUNSHINE. The best of all yellow Carnations. Produces blossoms of very large size, on splendid stems. Color a pure lemon yellow. This variety is difficult to propagate, although it grows readily enough when once rooted.

Price each, 25c; per doz., \$2.50.

E. K. HARVEY. A magnificent variety of our own raising. Blossoms simply enormous in size, with perfect stems and wonderful calyx. The flowers have a ground color of pure white, beautifully stained and marbled deep rose. Price each, 25c; per doz., $\$ \mathbf{2 . 5 0}$.

SPECIAL OFFER: One strong plant of each of the above superb Carnations for

$\$ 2.00$.

Fifty to one hundred lots of any of the above varieties at the rate of

\section{A Few Very Fine New Dahlias for the Season of 1928}

ARTIS. A splendid medium sized decorative Dahlia. Color a rich shade of fiery orange. Magnificent stems. A gem for cut flower work.

Price each $\mathbf{5 0}$ c.

AUREOLE. Those who grow Dahlias for cut flowers will find this a particularly useful variety. The flowers are quite small, perfectly double and bright orange amber in color. It belongs to the small flowered decorative class as several others of this set.

Price each 50c.

CHARLOTTE. This variety belongs to the small flowered decorative or rosette type Dahlia. Color is a rich golden orange. There is nothing more beautiful than a vase of these lovely long stemmed flowers.

Price each 75c.

CLOWN. One of the daintiest of all small flowered decorative Dahlias. Flowers average about three to four inches across and have a ground color of pure vermillion red, each of the petals being tipped pure white. A dainty variety for cutting purposes and wonderfully free blooming.

Price each $\$ 1.00$.

COLTNESS GEM. Among the small dwarf growing Dahlias this lovely variety from England is without question one of the finest in existence. The plants attain a height of some 18 inches. The flowers are single, brilliant orange scarlet in color and produce an unbroken mass of color from May until the time of frost. A bed of this variety in bloom is as brilliant in color as that of the well known geranium Paul Crampbell. The flowers are borne on thin wiry stems and in such quantities as to almost hide the foliage. There is nothing more beautiful than a border of this variety and it is equally adaptable for solid beds. There have been many of the so-called Coltness Gem hybrids sent out, but there has been nothing to equal the original variety.

Fine strong tubers each 50c. Per doz., \$5.00.

COURONNE D'OR. A magnificent flower any way you take it. Reminds one of Insulinde in size, stem and other particulars, differing in color only, the latter being a grand shade of orange and apricot yellow.

Price each $\$ \mathbf{3 0}$.

EMMA GROOT. A splendid decorative with immense flowers composed of broad overlapping petals slate blue and violet in color. Very free flowering. Price each 75c.

GARDEN LOVE. This charming small flowered Dahlia resembles a Zinnia in shape and size with much the same build. The plants attain a height of about 3 feet and present a veritable mound of exquisite lilac rose colored flowers. A splendid variety used as a border for the taller growing sorts.

Price each $\$ 1.00$.

HERA. We regard this variety as being one of the finest of all decorative Dahlias of its color. There is not a point by which you would judge a Dahlia which is not present in this glorious variety. It combines robust growth, enormous size of flower, a strong wiry stem and a simply magnificent color of true orchid pink. It is a wonderful keeper and every flower comes perfect. We have only a limited amount of this Dahlia to distribute this season.

Price each $\$ 2.00$.
KING HAROLD. A very fine cut flower variety. Stems as stiff as a gun rod holding the flowers well erect. For cutting purposes this variety is hard to beat.

Price each 75c.

LOCARNO. One of the finest of all modern Dahlias for cut flower purposes with lovely moderate size blooms borne on rigid stems of enormous length. The color is a sparkling golden yellow with an apricot reflex.

Price \$1.50.

MURILLO. An exquisite shade of salmon rose, a variety which lights up well under artificial light, has splendid stems and excellent keeping qualities. Price each $75 \mathrm{c}$.

ORIOLE. Similar to Charlotte in size and general characteristics. In color bright amber yellow.

Price each $75 \mathrm{c}$.

PAX. Medium size decorative and strictly in the cut flower class. The petals composing the flower are of loose artistic make up. The stems are exceedingly strong and rigid. The color is a rich shade of orange apricot.

Price each $\$ 1.00$.

PRINCE OF WALES. Another of the moderate size cut flower decorative type. Color deep terra cotta shaded with salmon. An unusual color and as beautiful as it is unusual.

Price each 75c.

PRINS CARNAVAL. A lovely small flowered decorative and one of the most striking varieties in this set. The blossoms are about four inches across, the principal ground color of the flower being a rich maroon crimson with the ends of each petal daintily tipped with white. Although we had thousands of Dahlias in bloom at our nurseries during the past season there were none that elicited more praise from customers than this variety. It is a gem for cutting purposes. Price each \$1.00.

SONNE IM HERZEN. Another of the new Holland types of Dahlias with small beautifully shaped flowers. Color a flaming orange. An exquisite variety.

Price each 75 c.

RAPALLO. A distinct fancy small flowered decorative. Blossoms are composed of broad evenly overlapping petals, ground color a rich shade of crimson maroon with the edge of each of the petals bordered with golden yellow. The contrast of colors to be noted in this variety is very striking and catches the eye at once.

Price each $\$ \mathbf{1 . 5 0}$.

NOTE. We have only limited stocks of the above new Dahlias and can only supply them as strong green plants from pots about May 15 th. These will be in fine growing condition at that time and you can depend on getting flowers from the plants in their final quarters from July onward.

SPECIAL OFFER: ..One each of the above new Dahias 18 varieties in all for

$\$ 17.50$. 


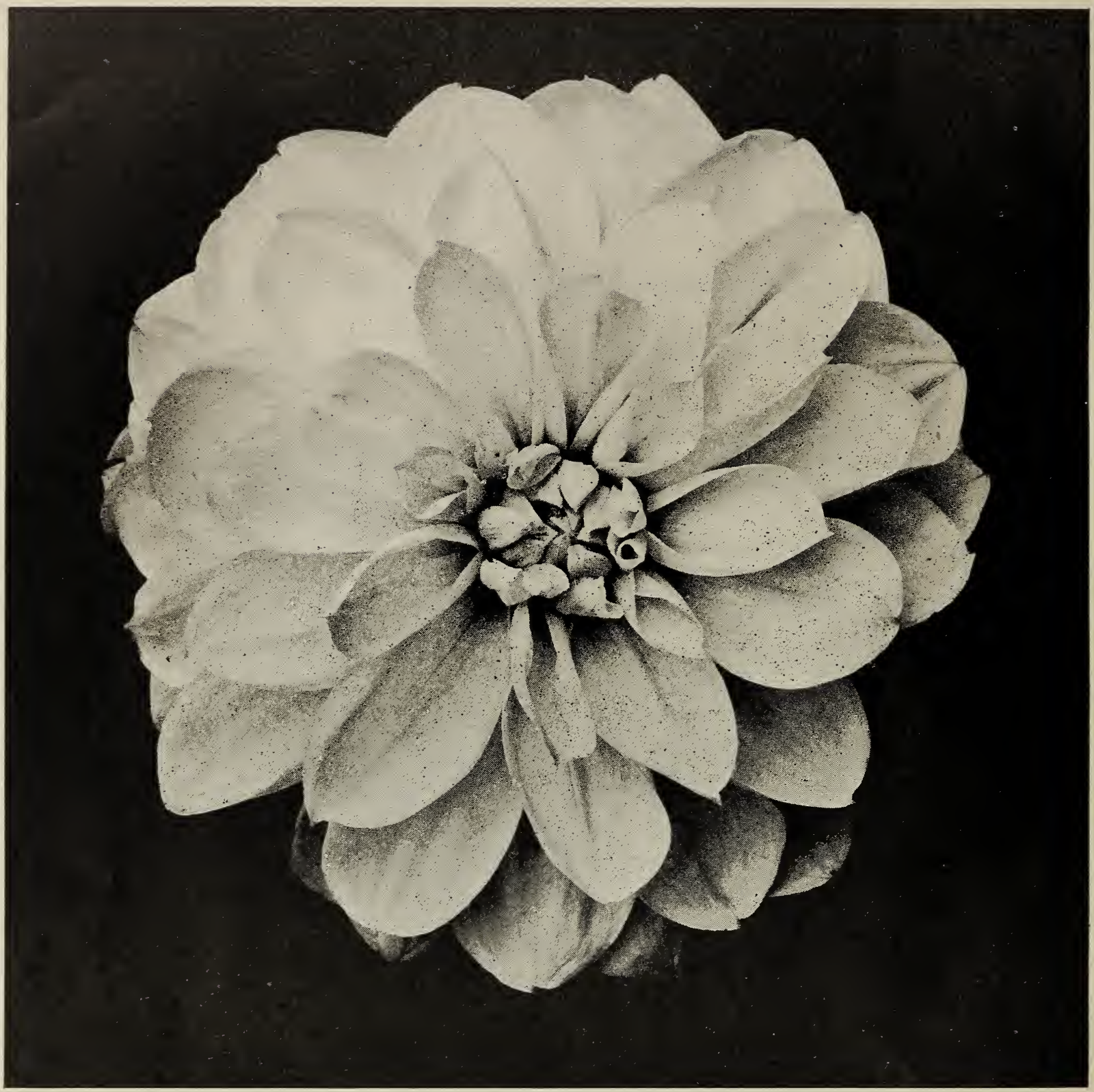

Polar Bear

\section{Dahlias}

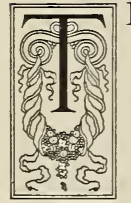

HE DAHLIA is one of our leading specialties. The collections which we offer you consist not only of the best and most up-to-date varieties from all sources, both domestic and foreign, but include a selection of very fine seedlings raised at our Montebello nurseries. We have carefully revised our collection season after season, inferior sorts have been discarded and better varieties substituted in their place. Particular attention has been paid to include in our collection only those which possess good stems, flowers of perfect form and decided clean cut colors. In other words, we have carefully considered all the points which go to make up a first class Dahlia. No weak neck varieties are included in the list submitted and customers purchasing Dahlias from us may depend on getting nothing but the best. In the case of some of the novelties noted in this catalog, we cannot furnish tubers this season, due to scarcity of stock, but will deliver them as green plants, growing in pots, about May 1st. A notation following the description of each of the different varieties is appended, which states whether they are to be supplied in tubers or green plants. Although it is not generally understood, Dahlias grown from cuttings in the Spring potted on and planted out in May, June or July, flower quite as freely as those grown from tubers. 


\section{New Choice Dahlias from Holland}

The varieties listed below might be regarded as a r.ew class in decorative Dahlias. Producers of new varieties have bent their efforts toward securing flowers of very large size. While these produce more or less miniature or middle size blooms, the blossoms attain a diameter of 4 to 5 inches when grown under natural conditions and not subjected to disbudding. For cut flower purposes these Dahlias will prove of great value. Their keeping qualities are remarkable and the flowers are produced far above the foliage on thin, wiry stems. There is a grace and delicacy about this new intermediate size class of decorative Dahlia which will appeal to everyone. Among the many thousands of Dahlias, which we grew at our Rivera plant during the past season, there were none which elicited more expressions of admiration from those who saw them, than these new Holland types. The set, which we are offering you, embraces a splendid selection of colors, all of which are charmingly bright and fresh.

ELTA. A lovely compact flower held perfectly erect on strong, wiry stems. In color, a delightful shade of soft salmon pink. Very fine. (Tubers.) Price each 75c.

GLOWING STAR. Beautiful bright crimson. Blossoms of model form, perfect in stem, averaging about 5 inches in diameter. A clean, brilliant and decided color. (Tubers.)

Price each 75c.

JOHN MENSING. Brilliant vermilion crimson. Petals somewhat pointed at the tips. A splendid keeper and ideal for cut flower purposes of any kind. The medium sized flowers are produced with great freedom from the beginning to the end of the Dahlia season. Exceedingly choice. (Tubers.)

Price each 75c.

MARIA HOUTMAN. A superb cut flower Dahlia. Blooms model as to shape. True middle size decorative form. Color deep golden orange, with salmon shadings. (Tubers.)

Price each 75c.

MENNY CARLEE. Pure snowy white, blossoms 4 to 5 inches in diameter. We believe this to be the best middle sized decorative white offered up to the present time. (Tubers.)

Price each 75c.

MR. LIX. A lovely shade of bright rich rose pink, a very desirable variety for cut flower purposes, as the color.

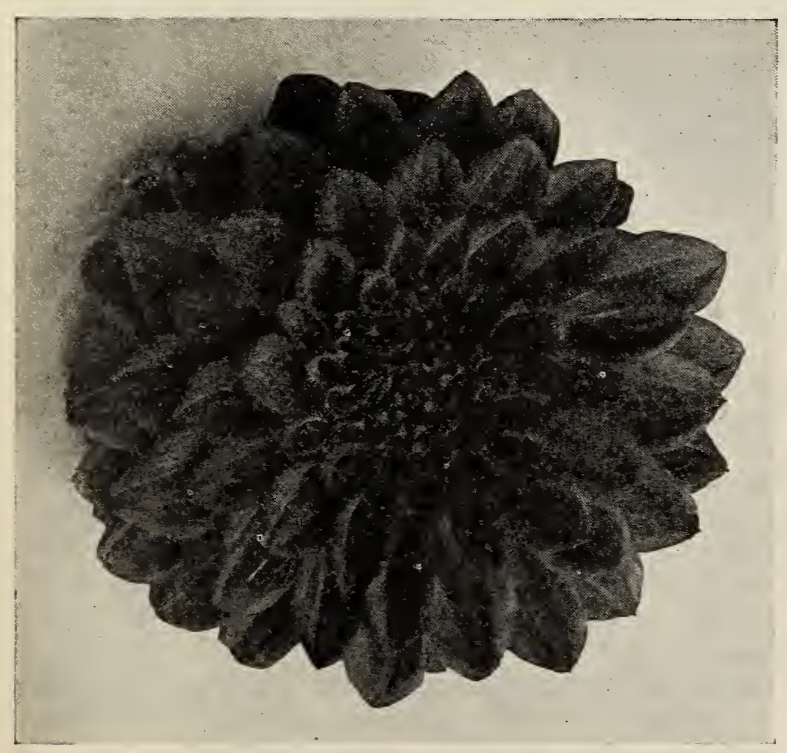

lights up well under artificial light. The plants in the field are a mass of flowers, held well above the foliage on stiff, stout stems. (Tubers.)

Price each \$1.00.

MRS. ENSCHEDE KVOY. This is simply a magnificent Dahlia, taken from any standpoint of view. The flowers are about 5 inches in diameter, models of neatness and form. Color, a grand shade of rich golden bronze, which glistens in the sunlight. Of the thousands and tens of thousands of flowers used in our floral dejartment during the past season, no single variety created more attention than this lovely Dahlia. The stems are long and stiff and the flowers are held absolutely erect. One of the finest varieties for cutting purposes in our entire collection. (Tubers) Price each 75c.

RAYONNANTE. Bright glistening canary yellow. One of the daintiest of this new middle size decorative class Dahlia. As with others of this set, it is a splendid cut flower variety, being a good keeper with splendid stems. (Tubers.)

Price each 75c.

SPECIAL OFFER: One strong tuber of each of the foregoing new Holland type of Dahlias for

$\$ 5.00$.

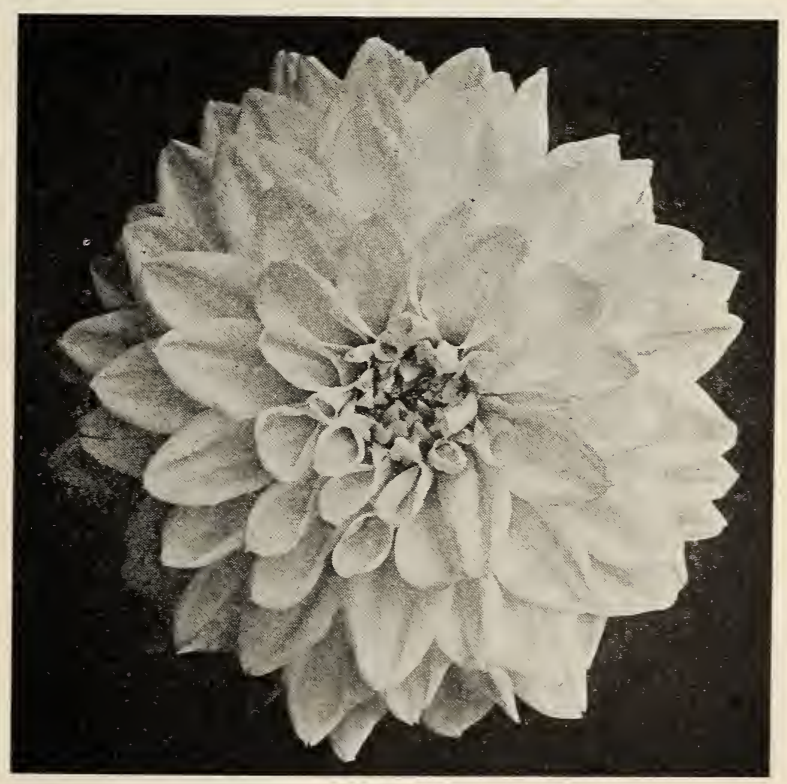


COCARDE. This superb novelty hails from Holland and was imported by us along with the middle sized decorative types featured above. As a variety for cut flower purposes this lovely new Dahlia is bound to take a premier position. The flowers are beautifully poised on strong, wiry stems, held well above the foliage. Its keeping qualities are the very best, the bløoms lasting as long as six days after being cut. Last, and not least, the combination of colors to be noted in its flowers is one of artistic effect. The basal ground color of the whole bloom is a wonderful shade of orange bronze with the tips of the petals delicately rimmed with scarlet. The flowers are intermediate in size between the pompon and show Dahlias, usually about $21 / 2$ to 3 inches across. We predict that this variety will be grown by the thousands by commercial cut flower growers, when better known. (Tubers.) Price each $\$ 1.50$.
SPECIAL OFFER: One strong tuber of each of the eight Holland varieties and one of Cocarde for $\$ 6.00$.

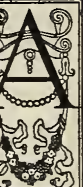

\section{Superb New Dahlias of the Polar Bear Race}

FEW seasons ago we sent out our famous white Dahlia Polar Bear, which has all the ear-marks of a perfect white, either for commercial or garden use. It is a variety distinct in its character, possessing as it does all the points which go to make up a good Dahlia, viz., length and stiffness of stem, flowering well above the foliage, so that the blooms stand out in bas-relief, keeping qualities when cut, form and contour of flowers and all other matters which might be considered essential for the perfect type of Dahlia. We were led to make further crosses in order to obtain other colors in this same type of plant. Although many crosses were made, we selected only a few of the very best and these are incorporated in the set which we are offering under the above head, and includes the variety, Polar Bear.

GOLDEN QUEEN. A bright golden yellow shading to intense orange at the center of the flower. A fine companion to Orange King, similar in contour of flower, otherwise identical as to stem, keeping qualities, etc. Disbudded flowers attain a diameter of 8 inches and over. (Tubers.)

Price each $\$ 1.00$.

LAVENDER QUEEN. A pure even and delicate shade of soft lavender, shading lighter toward the center of its channeled petals. Although this Dahlia is of the same progeny as others, in this set, it is distinct in its babit of growth, being somewhat shorter with smaller flowers.

ORANGE KING. Intense brilliant orange shot with scarlet at the base of the petals. These scarlet shadings serve to enhance the beauty and intensify the color effect of the whole flower. It is a superb novelty anyway you take it, and one which we feel certain will fill a long felt want in Dahlias of its particular color. (Tubers.)

Price each $\$ \mathbf{1 . 0 0}$.

ROSE QUEEN. A superb soft rose colored flower, petals beautifully channeled as in others of this series of crosses. A flower simply enormous as to size and although extremely large, there is a wavy appearance to the bloom which does not tend to grossness. It is a refined flower in every sense of the word. A wonderful keeper with just the right petalage. Stems can be cut 4 feet in length. (Tubers.) Price each $\$ \mathbf{1 . 0 0}$.

SALMON QUEEN. An exquisite shade of soft salmon pink shot with amber and gold. Although really a three-toned flower, the general effect of a mass of the cut blossoms is that of soft salmon pink. Very large as to size, perfect as to form and petalage. A Dahlia in the pastel shade class which we are certain will find many admirers. (Tubers.)

Price each \$1.00.

YELLOW PRINCE. A grand shade of pure lemon yellow which does not fade even under the hottest sun. Stem ideal, blossoms being held well above the foliage. Good stiff neck and all the other good qualities which its parent Polar Bear possesses. Similar as to form, with the same handsome deeply channeled petals. A wonderful keeper. (Tubers.) Price each \$1.00. 
POLAR BEAR. Among the various Dahlias which we offer for your consideration we doubt if there is one of greater intrinsic worth than this magnificent white decorative Dahlia. It fills a long felt want in Dahlias of its particular class, there being few, if any, which combine so many good qualities as this pecrless white. The plant is a very vigorous grower, the stems are long and rigid and hold the flowers perfectly erect under all conditions of weather. It is absolutely snow white in color and the faultessly formed blooms are composed of broad deeply channeled petals, which, when fully developed, outline a flower of magnificent contour and gigantic proportions. This remarkable Dahlia was exhibited during 1923 at the show of the Royal Horticultural Society, Vincent Square, London, where it created a sensation and in 1924 was sent to the British National Dahlia Society trial grounds at Wisley, England, for further test, where it obtained the high award of a first class certificate. This award speaks volumes for its quality. As a cut flower for home decoration, or commercial work, it is head and shoulders over any white Dahlia on the market today. It is a wonderful keeper. We have had blossoms last fully six days in the cut state. (Tubers.)

Price each, $\$ \mathbf{1 . 0 0}$.

SPECIAL OFFER: One of the above Polar Bear types of Dahlias, including one Polar Bear-7 in all-for $\$ \mathbf{\$ 6 0 0}$.

\section{Three Dainty Miniature Decorative Dahlias}

ine three following varieties are gems for cur ting purposes and are splendid types of the new smail flowered decorative class. These varieties should be in every first class collection.

IRENE. A lovely small flowered decorative Dahlia belonging to the miniature class. The blossoms are only 2 to 3 inches in diameter, the color is an exquisitr. shade of old rose. A gem for cutting purposes. (Grees. prants, May lst.)

Price each 7bc.

LITTLE JEWEL. One of the daintiest of the newer race of miniature decorative Dahlias, blossoms about $21 / 2$ inches in diameter. Absolutely perfect in form and a most entrancing shade of pure peach blossom pink. It

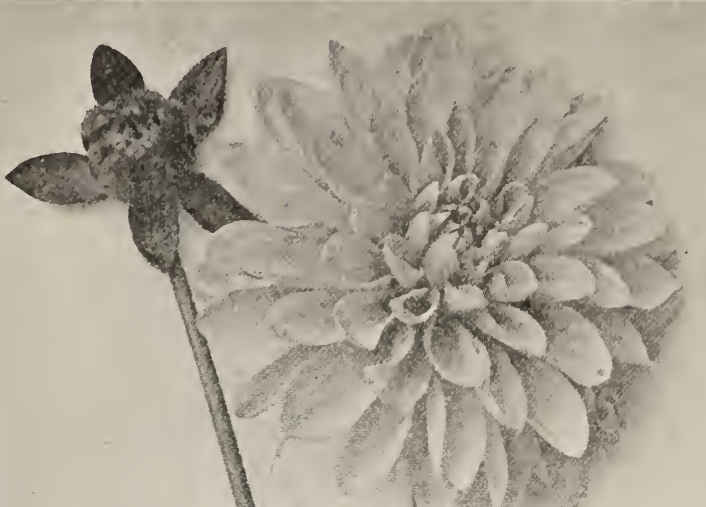

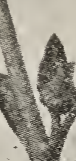

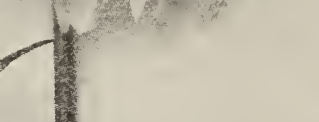




\section{Howard $\mathcal{E}$ Smith's Select List of Large Flowered Dahlias}

CHAMPAGNE (Decorative). One of the largest Dahlias in cultivation today. A model Dahlia from any point it might be considered. Gigantic flowers of perfect formation are produced on long rigid stems. The color is a shade diffcult to describe. The originator's description is as follows: "Color is delightful in warm Autumn shades, varying from burnished copper to dull old champagne and chamois." (Tubers.) Price each \$1.50.

DELICE (Decorative). An old standard favorite. Blossoms are only of moderate size, but are freely produced. In color, a delicate shade of soft pink. It is one which is grown largely for commercial purposes. Its color has never been surpassed. (Tubers.)

Price each 35c.

DR. TEVIS (Decorative). Unquestionably one of the finest Dahlias ever introduced and one of the must popular. Blossoms of magnificent proportions. The color is unique, being a blending of copper, old rose and gold. Wonderful stems and very free in bloom. (Tubers.)

Price each $\$ \mathbf{1 . 0 0}$.

ENTENDARD D'LYON (Hybrid Cactus). An exceedingly choice Cactus Dahlia, large in size, unique in color, the latter being a very attractive shade of glistening royal purple. Tubers.)

Price each 75c.

GLOIRE DE VERDUN (Decorative). An extremely large, bright crimson decorative Dahlia. Petals beautifully notched, more or less flat and reflexed in the open flower. An ideal variety for cutting purposes, the stems being of great length, very rigid. One of the best of its color. Highly recommended. (Tubers.)

Price each $\mathbf{7 5 c}$.

GEORGE WALTERS (Hybrid Cactus). Gigantic sized flowers of informal shape; pink and salmon in color, with shadings of gold at the base of the petals. Always a favorite. One of the best of its particular color. (Tubers.) Price each $\mathbf{7 5 c}$.

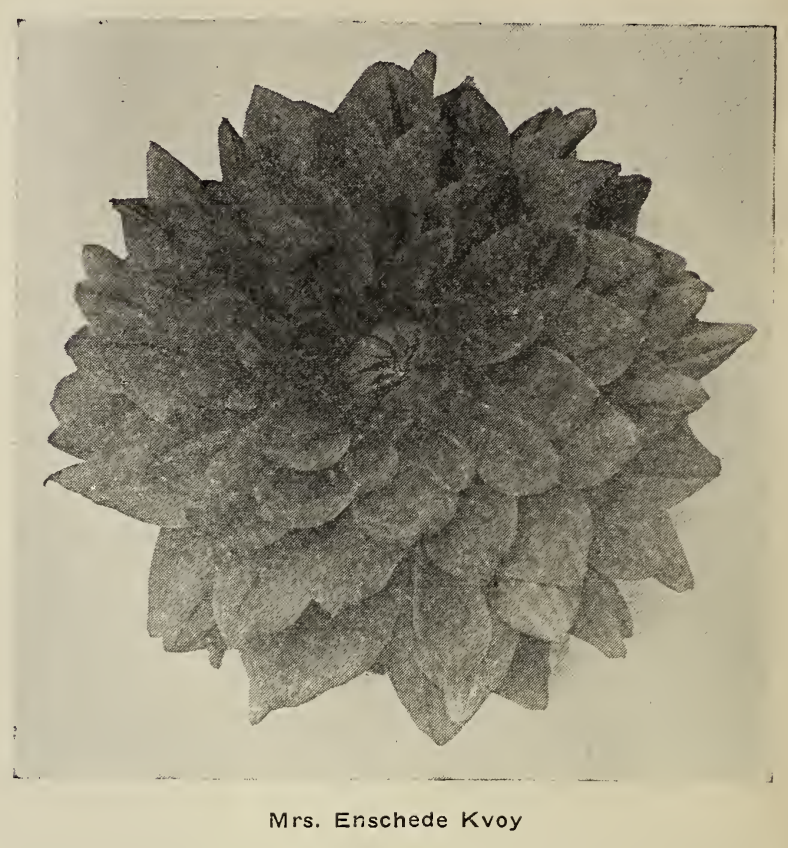

GOLDEN WEST (Cactus). A grand variety for cutting purposes. Flowers produced in profusion, stems first class. A Dahlia of great worth as a commercial cut flower. One of the most popular varieties grown for the market today. Keeping qualities the best. ( $\mathrm{Tu}$ bers.)

Price each 35c.

HALVELLA (Decorative). A Dahlia of superb form and substance, bearing flowers of great size, with splendid depth. The arrangement of the petals is well-nigh perfect. In color, a soft shade of old rose. Blossoms of enormous size, freely produced. An exquisite variety for cut flower purposes. (Strong green plants, ready May 1st.)

Price each $\$ \mathbf{1 . 0 0}$.

HORTULANUS FIET (Decorative). Shrimp pink overlaid with gold. A large, perfectly formed bloom. Always scarce. (Strong green plants, ready May 1st.)

Price each $\$ 1.00$.

INSULINDE (Hybrid Decorative). Easily one of the finest of all Dahlias in cultivation today. Blossoms of enormous size, composed of petals arranged in loose, curled formation. The flowers are beautifully poised on the ends of long, rigid stems. The color is a magnificent shade of tawny orange, the reverse of the petals shot with rose. Flowers on disbudded plants grow to enormous porportions. It is a Dahlia without a fault. ( Tubers.)

Price each $\$ \mathbf{1 . 0 0}$.

JEAN CHAZOT (Cactus). A superb new hybrid decorative Cactus Dahlia from France and easily the best of its color introduced up to the present time. The flowers are extremely large, produced on fine, stiff stems. A splendid keeper when cut. Color, a beautiful golden bronze, with just a faint suffusion of red. (Tubers.)

Price each $\$ 1.00$ 
JERSEY'S BEAUTY. One of the most remarkable decorative Dahlias introduced in modern times. It is without a single fault, having a wonderful color of rich true rose pink, uniform throughout the flower. Bloom of remarkably large size, when disbudded usually 6 to 7 inches in diameter. A stem that is all that you could ask for, being very rigid and carrying the flowers perfectly erect. Its keeping qualities are perfect, lasting in the cut state for several days, its decorative quality as a cut flower for large vases, especially when used under artificial light, is par excellence. In short it is a Dahlias which should be in everybody's garden. It was formerly sent out at a very high price, our original stock plants costing us some $\$ 10.00$ each. Having worked up a large stock, we are able to offer it this year at a low figure.

(Tubers or green plants).

Price each

$\$ 1.00$.

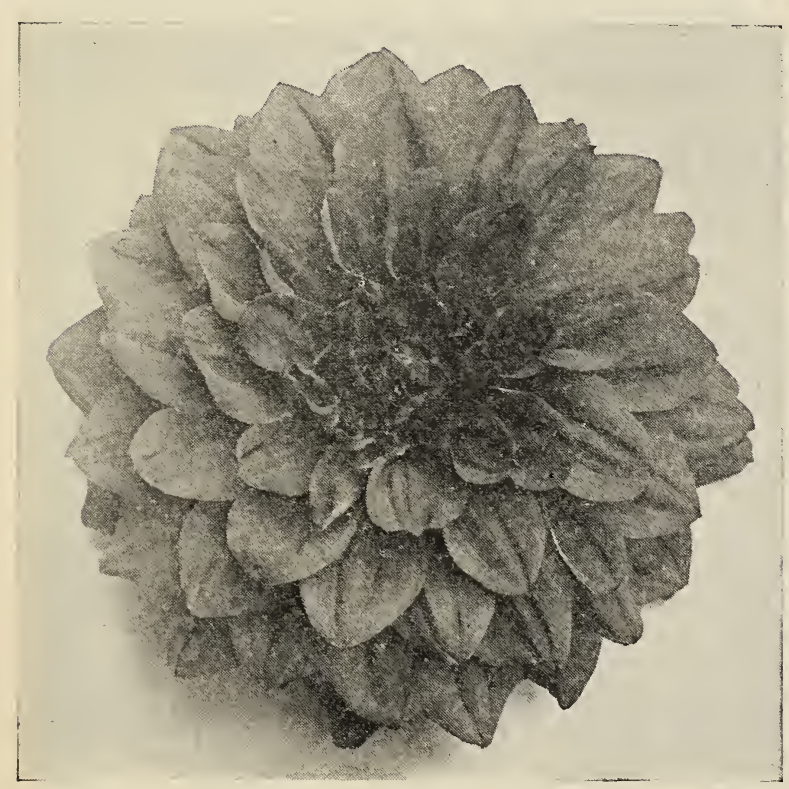

John Mensing

KITTY DUNLAP. A very handsome large flowered decorative Dahlia. A very free bloomer with splendid long stiff stems. The color is unique, being almost equivalent to that of the well known American Beauty rose. (Tubers.)

Price each $\$ \mathbf{1 . 0 0}$.

MAD. VICTOR CAYEUX (Decorative). A sensational novelty in the decorative class of Dahlias. The plant is a very tall grower, the blossoms of enormous size, held perfectly erect, with beautifully reflexed petals. Color, a superb shade of burnt orange magnificently displayed in the enormous flowers. Flowers may be cut with 4 or 5 foot stems. A regal variety in every sense of the word.

Tubers, each $\$ \mathbf{1 . 0 0}$.

MRS. SUZANNE B. HOLMES (Cactus). One of the. finest dark crimson maroon Cactus Dahlias in cultivation. The blossoms are only of moderate size, but there is a perfect arrangement to the petals. Stems long and stiff. The whole flower is of uniform and neat arrangement. We raised this Dahlia several years ago and believe it to still be one of the best of its type.

Tubers, each 50c.

MARY C. BURNS (Decorative). A decorative Dahlia of superb form and substance. The flowers are of immense size, beautifully poised on strong, rigid stems. No weak necked flowers ever manifest themselves in this variety. The color is a brilliant shade of golden orange with the reverse side of the petals reddish bronze. One of the most attractive of all Dahlias. Tubers, each 75c.

MINA BURGLE (Decorative). Pure rich scarlet flowers of moderate size, produced on long wiry stems. A very popular market variety. Keeping qualities the best. The color of the flower is intensely bright and glowing.

Tubers, each $35 \mathrm{c}$.

MADONNA (Decorative). More or less similar in form and general characteristic of growth to Delice, but light rose pink in color. While the flowers are not large they are of splendid value for cutting. Stems stiff and viry, of exquisite effect in vases.

Tubers, each $35 \mathrm{c}$.

MABEL B. TAFT (Decorative). A splendid richly flowered decorative Dahlia. The flowers have a ground color of canary yellow with a suffusion of pinkish apricot. Large as to size, but requires plenty of disbudding.

Tubers, each $\mathbf{7 5 c}$.

NIEBLUNGENHORT (Hybrid Cactus). Shrimp pink with shadings of bronze. A flower of handsome form and large dimensions. Not a new variety, but one which is always scarce and in demand.

Tubers, each $75 \mathrm{c}$.

PINK BEAUTY (Decorative Cactus). We raised this Dahlia a few years ago. It is a giant flowered cactus type with a wonderfully refined form, in one of the most delightful shades of color to be found. The blossoms attain a diameter in disbudded plants of 8 to 10 inches. The petals are outstanding, beautiful quilled. In color, a delicate shade of lavender pink, shading lighter at the center of the flower. Unexcelled for cutting purposes. Splendid stems. Tubers, each $75 \mathrm{c}$.

PRIDE OF CALIFORNIA (Decorative). Intense glowing cardinal red. A popular variety with cut flower buyers owing to its brilliant color, large size and wonderful stems. Should be included in every collection.

Tubers, each 50c.

PRIMROSE DAME (Decorative Cactus). One of the loveliest of our entire collection and one that we feel sure will please the most critical Dahlia grower. The combination of color in this variety is quite distinct from any other that we know of. The ground color of the flower is primrose yellow, overlaid with coral pink. The blossoms are of the true Cactus decorative type with beautifully curved and twisted petals. The flowers are poised on the end of a long stiff stem. Extra good for cutting purposes. 
PRIDE OF SAN FRANCISCO (Decorative.) A flower of superb form and substance, borne on strong, rigid stems and a great advance by way of color in Dahlias of its class. It is remarkably free in growth with the sten clothed with heavy, closely set dark green foliage. It is also unique as to color, being an exquisite shade of coral pink, merging to amber and gold at the base of the petals. A grand variety and should be included in every collection.

Tubers, each $\$ \mathbf{1 . 0 0}$.

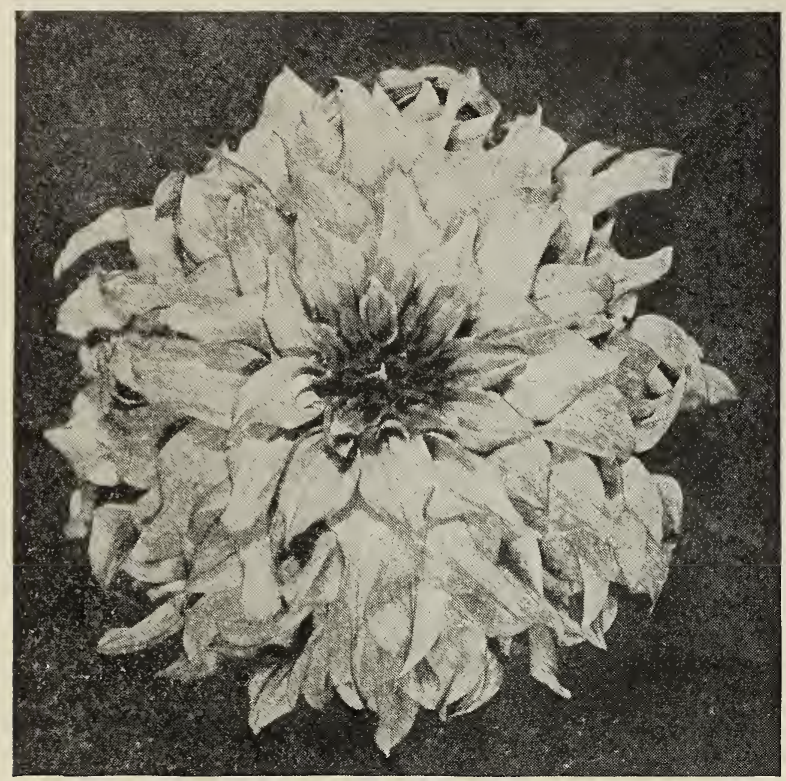

Insulinde
PRINCESS PAT (Decorative). A decorative Dahlia bearing blossoms of immense size and perfect form. The flowers show great depth, the center being high and full. The stems are perfect and the color one much sought after, being a pleasing shade of old rose. Tubers.

Price each) $\$ 1.00$.

RISING BEAUTY (Hybrid Decorative). A hybrid decorative Dahlia with immense flowers, borne on long, straight stems. The blooms have long, narrow petals, scarlet in the body, with the end of the petals tipped golden yellow. Strong, green plants, ready May 1 st.

Price each $\$ \mathbf{1 . 0 0}$.

SOUV DE GUSTAV DOAZON (Decorative). Bright fiery red. Immense as to size, superb as to form. An old Dahlia, but still a good one. Tubers, each 35c.

ST. FRANCIS (Decorative). A delightful shade of soft cream, flushed with pink on the outer portion of the petals. Blossoms of immense size, exceedingly free. A splendid addition by way of color to the list of decorative Dahlias.

Tubers, each $\$ 1.00$.

QUEEN OF CALIFORNIA. Flowers of extremely large size and most attractive coloring. The basic color of the petals is orange red with a lovely suffusion of old gold. Stems of splendid quality very free blooming. Comes very large when disbudded. (Tubers)

Price each $\$ 1.00$.

WODAN (Decorative). Flowers of enormous size. Color, exeptional, being old rose tinted with gold.

Tubers, each 50c.

SPECIAL OFFER. One each of the above select large flowered decorative Dahlias, 31 in all a splendid collection of exemplary worth for \$22.50. (Regular price \$24.75)

\section{Pompon Dahlias}

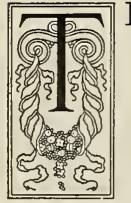

HERE is a constant and growing demand $f$ or this elegant class of small flowered Dahlia. They are in reality miniature forms of the large flowered show type. Although absolutely formal in shape, there is a grace and beauty about them which makes them splendid subjects for decorative effects of all kinds, being equally valuable for a show in the garden or when used as cut flowers for interior decoration. The stems are strong and wiry and the colors charmingly bright and fresh. They have the additional a dvantage of outlasting, insofar as keeping qualities are concerned, almost any other type of Dahlia. They will give you a constant succession of cut flowers from early summer until late autumn.

ADELA. A distinct shade of rosy crimson.

Tubers, each 35c.

AIMEE. An elegant pompon Dahlia of a bronzy Autumn tint, very free with fine long stems.

(Tubers) Price each 50c.

AMBER QUEEN. Bright golden amber of fine form and habit. Good for cutting. (Tubers.) Price each 50c.

DARKNESS. Dark velvet maroon. One of the best of this set. (Tubers)

Price each $\mathbf{5 0 c}$.

EUNICE. Delicate light lavender shading to pink One of the best pompon Dahlias of this color. (Tubers)

Price each 50c.

FLORA. A bright golden canary yellow. (Tubers) Price each 50c.

GLOW. A lovely shade of old rose. A cheerful bright color and well deserving of its name. Price each 50c.

GUIDING STAR. One of the most distinct of all pompon Dahlias. Petals closely set, beautifully imbricated at the tips, giving the flower a beautiful fringed appearance. Although this Dahlia was introduced years ago, we question very much as to whether it has been superseded by any other white in the pompon class. A variety of exquisite effect when used as a cut flower. Stems good. Very profuse in bloom. An ideal variety.

Tubers, each 35c.

GRETCHEN HEINIE. Base of petals pure white, edges picoteed with deep rosy crimson. A flower of charming form and color. Extra good. (Tubers)

Price each 50c.

JULIET. A neat, compact flower. Base of the petals deep yellow, shading to rosy heliotrope. (Tubers)

LEILA. Elegantly formed pompon. Price each 35c.

Base of petals deep chrome edged with carmine. Petals occasionally stippled with salmon.
Tubers, Price each 35c. 
MYRA. In color, crushed strawberry and gold. Flowers quite small, but of perfect form. (Tubers)

Price each 35c.

PHYLLIS. An exquisite variety. Ground color deep rich yellow with heavy shadings of red. Very free.

(Tubers) Price each 35c.

NEATNESS. An exquisite shade of clear lavender.

Tubers, Price each 35c.

RED INDIAN. Bright crimson scarlet.

Tubers, Price each 35c.

ROSEA. A deep shade of carmine rose. Shows up particularly well under artificial light. Tubers

Price each 35c.

WHITE POMPON. Pure white perfectly formed blooms with the imbricated petals to be noted in the variety Guiding Star. One of the best. (Tubers)

Price each 50c.

SPECIAL OFFER. One each of the above 17 pompon Dahlias, a distinct and beautiful collection with a full representation of all of the best varieties in this class for \$6.00. (Regular price \$7.15).

\section{Paeony Flowered Dahlias}

A handsome class which has strongly grown in popular favor in the last few years. The blossoms are semi-double with large wavy petals, quite informal in their general make-up but very decorative in character. In great demand on account of their value as cut flowers.

COMTE DE LA PARX. Old rose, suffused gold. Tubers, each 50c.

DRUM MAJOR. Plants of much branched habit, bearing without any artificial manipulation, such as disbudding, etc.; large, long stemmed blossoms. When disbudded can be grown to immense size. In color, a twotoned flower, the base of the petals showing a zone of rich orange, gradually merging to velvety crimson scar'et. Ground splashed and stained with golden yellow. A

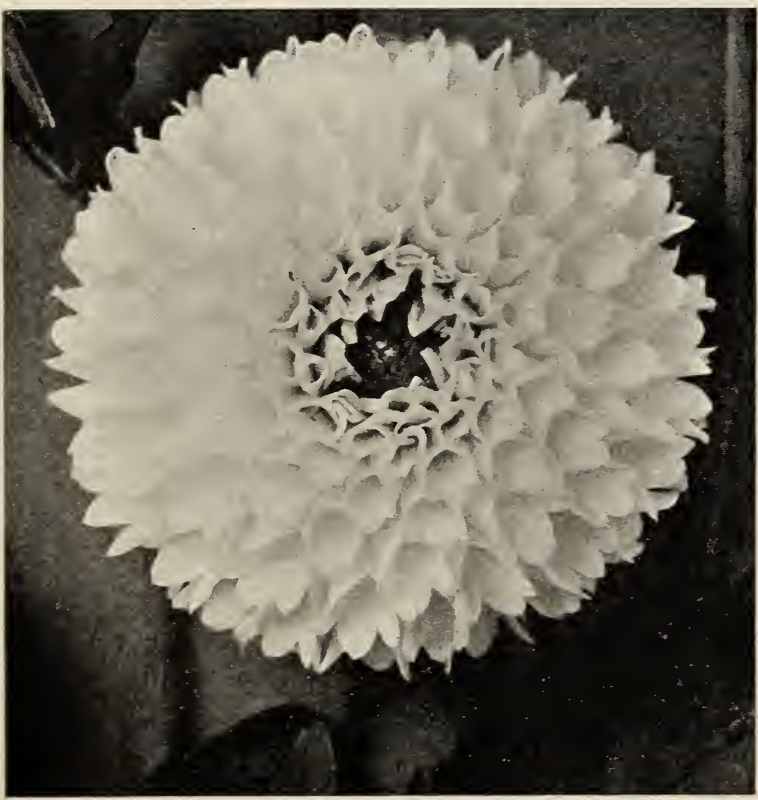

Guiding Star

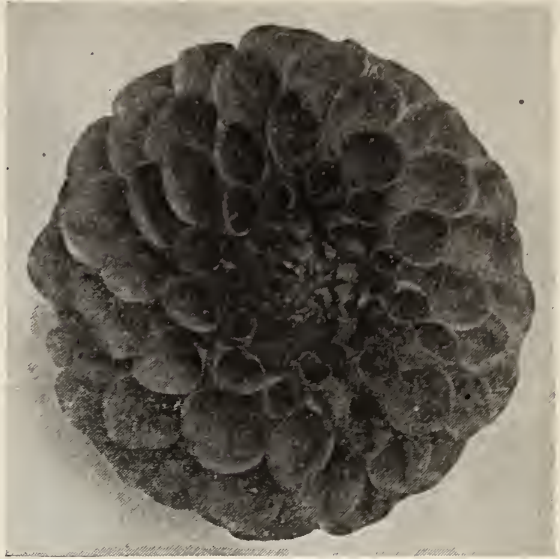

Cocarde

superb variety for cutting purposes, the informal shape of the flower adding greatly to its effect as a decorative cut bloom.

Tubers, each $\$ 1.00$.

NO. 935. Snowy white. Extra fine. Tubers each 50c.

NO. 952. Orange scarlet, shaded yellow.

Tubers, each $\mathbf{5 0 c}$.

\section{SPECIAL OFFER} for

One each of the preceding Paeony flowered Dahlias, $\$ 2.25$.

\section{Show Dahlias}

We offer you a collection of a few of the best of these old-fashioned types of Dahlias. Although not so graceful in form as the Cactus or Decorative, they are decidedly better keepers. Their richness in color and formal shape of bloom find many admirers.

CALEB POWERS. A delicate, soft pink of splendid form and contour.

T.ubers, each 35c.

DOROTHY PEACOCK. A pure, even shade of shell pink.

Tubers, each 35c.

MOUNT BLANC. A pure white show of refined form and splendid substance. About the same form and contour as the yellow variety, J. C. Vaughan. One of the best of its color.

Tubers, each 35c.

MR. GLADSTONE. One of the best pure pink show Dahlias. Blossoms model as to form. One of the best of its class.

PURPLE GEM. Bright purple crimson.

Tubers, each 35 .

Tubers, each 35 c.

SPITFIRE. Bright scarlet, intense in color; a veritable gem.

Tubers, each $35 c$.

J. C. VAUGHAN. Bright canary yellow. One of the best yellows in Commerce today.

Tubers, each 50c.

SPECIAL OFFER. One each of the above very fine Show Dahlias, 7 varieties in all for $\$ 2.25$.

(Regular Price \$2.60).

\section{CULTURAL NOTE}

Dahlias are strong, vigorous growers and require a rich soil with abundant supplies of water during dry weather. The beds should be in a fully exposed sunny position and should be well enriched with well-rotted manure, dug deeply into the soil. Three feet is about the proper distance apart for planting. 


\section{Chrysanthemums}

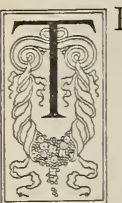

HE Chrysanthemum has been well named "The Queen of Autumn" and there is no class of herbaceous plants so indispensable for garden decoration or for cutting purposes. The range and variety of types is very large and includes those of the Japanese class with their immense fluffy blooms, the formal large flowered incurved sorts, the dainty pompon or button chrysanthemum, the anemone flowered class and the handsome singles. During the past few years the small flowered types such as those of the pompon, single and anemone sections have become very popular. Their extremely decorative effect in the garden is beyond compa re and during their blooming season, are a riot of color in all the glowing Autumn tints. Nothing more beautiful can be imagined in floral effect than low borders or beds planted with anemone, single or pompon Chrysanthemums. The flowers are borne so profusely as to entirely hide the foliage. The royal stretches of color obtainable with these beautiful flowers will delight the eye and contribute materially to the life of an autumn garden. The plants we offer are all propagated from vigorous soft wood top cuttings grown on in 2 " pots. The varieties noted in all of the collections will be ready for delivery about April 20th.

\section{Eight Splendid Novelties In Small Flowered Chrysanthemums of the Middle Size Hardy Decorative Type}

The varieties comprised in this collection are similar in size to those of the anemone class with flowers three to four inches in diameter when allowed to grow in a natural manner. Blossoms produced in large trusses. Splendid for bedding or cutting purposes. The varieties in this collection are superb in quality and represent a distinct advance in their particular class.

BRONZE QUEEN. A clear bronzy yellow. A variety of English origin. One of the most beautiful of the small flowered Chrysanthemums. Splendid for pot work, bedding or cutting purposes. Price each 35c.

BRIGHTNESS. This variety is also an imported new variety. The flowers are perfectly double. Informal in shape with broad strap-like petals. Very free fliwering. A gem for pot work. Price each 35c.

MAUDE. Rich Indian red on opening, shading as the flower develops, to bright reddish gold. Petals narrow. Flowers neat and compact. A grand acquisition.

Price each 35c.

GOLDEN BUTTERFLY. Pure bright gold. One of the finest novelties in this set. A late flowering variety which materially prolongs the blooming season.

Price each 35c.
JEAN PUTTRIDGE. One of the most remarkable small flowered Chrysanthemums we have ever grown. The color is the purest shade of golden bronze, uniform in color from the opening bud to the fully developed flower. Wonderfully rich under artificial light. Flowers produced in dense heads, with blossoms a model in form. We cannot recommend this variety too hig $g^{-1} l y$.

Price each $50 \mathrm{c}$.

HOLLICOT YELLOW. An imported variety obtained in the same set as Bronze Queen and Jean Puttridge. The blossoms are a beautiful bright canary yellow. A novelty of premier worth. Frice each 35̃c.

MALYA. Flowers similar in form and size to the exquisite variety Jean Puttridge. Color a unique shade of white overlaid with blush pink. A lovely combination of colurs.

Price each $35 \mathrm{c}$.

SNOWDRIFT. A very free flowering variety of purest white. The handsome flowers are prettily reflexed and sume 2 to 3 inches across.

Price each 35c.

SPECIAL OFFER. One each of the above novelty decorative Chrysanthemums, a set of unquestionable worth and beauty for $\$ \mathbf{2 . 5 0}$. 


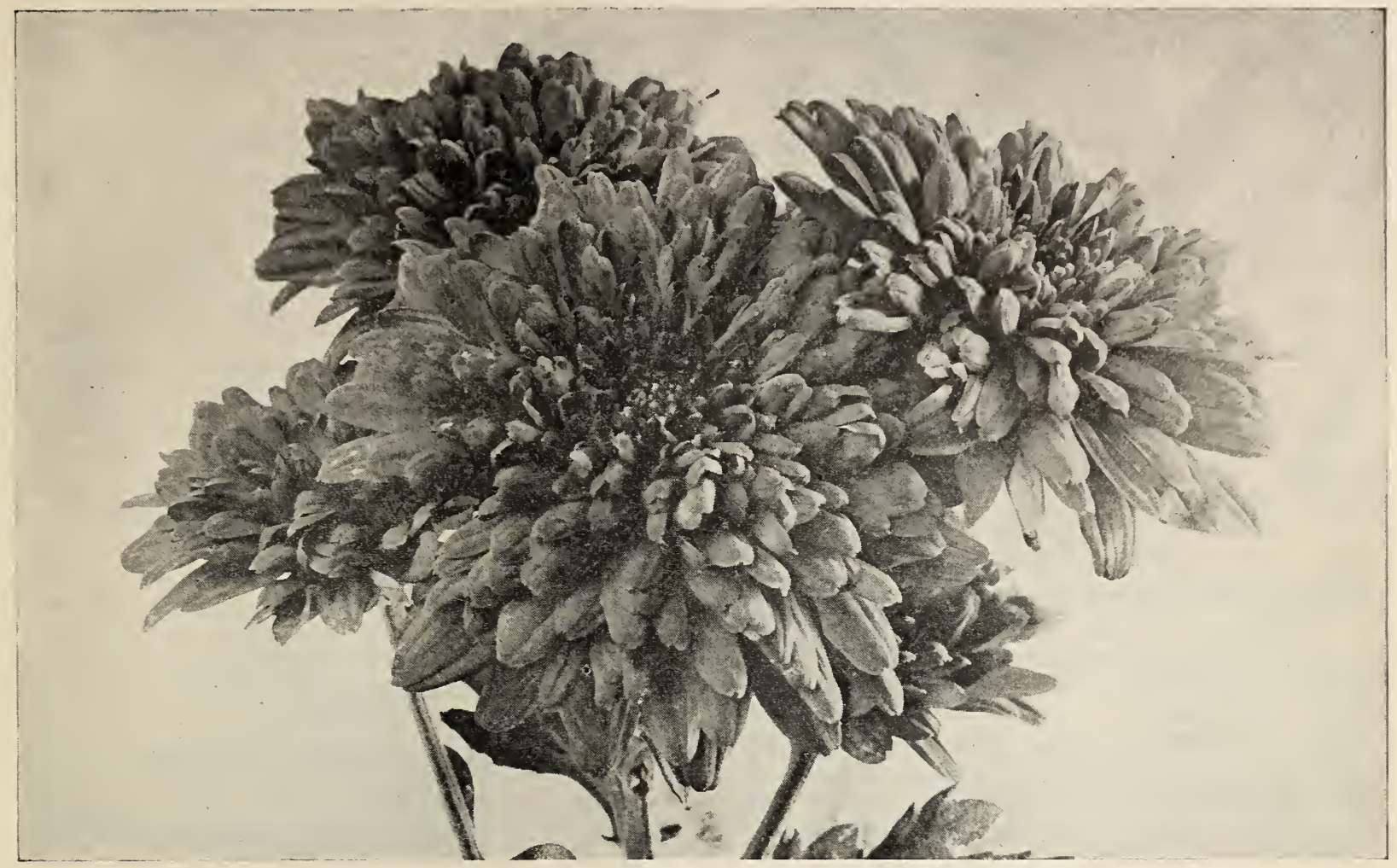

Jean Puttridge

\section{CHRYSANTHEMUMS OF THE JAPANESE CLASS}

The various varieties comprised under this heading are the very large flowered sorts, either formal in shape, such as the incurved and reflexed forms, or those where the petals are curled and interlaced. They are varieties which, in order to obtain maximum size, disbudding must be resorted to. If allowed to grow in a natural form, the flowers are produced in spray-like form and are larger than those of the hardy anemone or single flowered types. We would refer you to the appended cultural notes for the treatment concerning disbudding, etc.

\section{JAPANESE TYPES-WHITE}

ANTIGONE. Immense pure white flowers. Very double. Plants quite dwarf.

AUTOCRAT. Immense snow white blooms and exceedingly fine foliage.

CRYSTAL GEM. A pure white incurved. One of the best varieties for flowering in October.

FLORENCE DENZER. A good white variety.

JOSEPHINE FOLEY. An excellent pure white, suitable for exhibition purposes. Flowers incurved with fine stem and foliage.

LYNNWOOD HALL. A splendid cut flower of immense size. Pure white.

MRS. R. OBERTHEUR. Pure white.

MISS NELLIE POCKETT. A superb variety from Australia. Petals long, drooping and interlaced. Flowers of great depth and breadth.

MRS. F. J. TRANTOR. Giant reflexed blooms. creamy white, occasionally penciled rose pink.

MRS. S. J. REUTER. A beautiful pure white. Very desirable.

OCTOBER FROST. A very early blooming white, of large size
OCONTO. A white incurved with rigid stem and perfect foliage.

PRESIDENT TAFT. Pure white Japanese incurved. Extra good stem and foliage.

THANKSGIVING QUEEN. Large creamy white. Comes just right for Thanksgiving.

WHITE CHIEFTAIN. A pure white sport of Chieftain, quite as good as its parent.

WILLIAM TURNER. One of the most remarkable of all Chrysanthemums as to size, ten to twielve inch flowers on well-grown plants being quite common. Splendid for cutting.

\section{JAPANESE TYPES-YELLOW}

BESSIE GODFREY. A broad petaled canary yellow. Incurved.

DECEMBER GOLD. One of the best late yellows. Reaches perfection during December.

ETOILE DU NORD. One of the richest yellows in our collection. A grand golden yellow color.

GOLDEN GLEAM. Bright, glistening golden yellow. Extra choice.

GOLDEN QUEEN. The best yellow for October. Matures about the 10th. Incurved. 
MAJOR BONAFFON. Incurved yellow of regular formation. One of the best commercial varieties.

MARIGOLD. A yellow of unsurpassed beauty, both as regards size and color. Matures about October 20th.

MAD. PAOLO RADAELLI. A very large yellow, faintly tinted pink.

MONTEBELLO. Late yellow irregularly incurved. Pure bright canary yellow, Japanese incurved type. This variety is especially fine during the months of November and December.

MRS. R. C. PULLING. Clear, bright yellow in color and a flower of large size. One of the best varieties for exhibition purposes.

MRS. F. J. TAGGART. A grand late yellow.

MONSIEUR PECHON. An enormous incurved golden yellow. Very double.

NAGOYA. A very late flowering golden yellow. Reaches perfection about December 1st.

\section{JAPANESE TYPES-RED}

ADA BROOKS. A lovely Japanese variety of very large size. Interior of the petals rich bronze red, exterior pure bronze.

ADELE GRISWOLD. Bright red in color. Fine stem with excellent foliage.

EDGAR SANDERS. Bronze with lighter reverse. Extra large flowers. Fine, heavy foliage.

F. T. QUITTENTON. Reflexing deep crimson red. Immense size.

INTENSITY. Red, bronze reverse. A strong grower. MRS. R. F. FELTON. Rosy terra cotta red.

WILLIAM R. MEREDITH. Dark crimson red with gold reverse. Fine foliage, good stem. An unusual color.

\section{JAPANESE TYPES-PINK}

CHIEFTAIN. A very popular commercial pink. Extra good stem and foliage.

GOOD GRACIOUS. A splendid variety which throws fine, large blooms. Petals long and narrow. Irregularly incurving.

LADY HOPETOWN. Light pink. A beautifully formed bloom. Dwarf.

LAVENDER QUEEN. A large reflexed lavender pink.

MEUDON. One of the best pinks in cultivation. Im mense in size. Unsurpassed.

MLLE. JEANNE ROSETTE. Narrow quilled petals. Very double flowers. Soft pink in color.

MISS LUCY EVANS. A beautiful shade of heliotrope pink. Center petals incurved, outer petals reflexed.

MRS. COOMBES. A pleasing shade of deep pink.

PINK ROSETTE. Blossoms are of immense size, petals tubular.

SMITH'S SENSATION.....A delicate shade of light pink, beautifully incurving in form. A fine exhibition variety.

T. RICHARDSON. An extra choice pink variety, with silvery reverse, form loosely incurved.

UNAKA. An exquisite pink.

\section{JAPANESE TYPES-PURPLE}

MRS. T. CARRINGTON. Rosy purple with silver reverse. Good foliage, fine stem and large blooms.

MONS. ANTONIN MARMONTEL. Rosy purple. Enormous exhibition variety.

Price of any of the foregoing varieties, each $25 \mathrm{c}$; per dozen, $\$ 2.50$; per $100, \$ 17.50$.

\section{Chrysanthemums-Hardy Varieties}

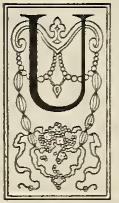

NDER this heading we offer you a selection of the small flowered types of Mums including those of the pompon, single and anemone flowered class. These small flowered Mums are today one of the most popular of all Autumn flowers. Their dainty blossoms are borne in spray-like masses, they are exquisite for interior decoration, last well when cut, require no artificial manipulation, such as disbudding, etc., and we believe are one of the most popular of any of the classes of Mums grown. They are charming when planted in masses in the garden, or when used as cut flowers. The rich shades of golden bronze, Indian red, etc., which manifest themselves in this class of Mum are truly suggestive of Autumn. The collection which we offer you contains some of the finest varieties introduced $t_{0}$ date.

\section{ANEMONE FLOWERED TYPES}

CO-ED. A very distinct anemone flowered type. Flowers of medium size. In color, an exquisite shade of dark rosy lavender. Nothing more beautiful can be imagined than a vase of this variety.

KATHERINE SIMMONS. A variety with a wellcrested center, the outer petals tubular in formation. Soft pink in color.

LILLIAN DOTY. Soft shell pink, turning lighter as the flower ages.

MRS. H. HOGBEN. Orange bronze. A charming color for table decoration and has every other desirable attribute. Medium height and growth.

MRS. F. J. GORDON DEXTER. A large flowered anemone Chrysanthemum, semi-double in form. Guard petals irregular in formation, giving the flower a spidery effect. Center cushion, creamy yellow. Extra choice.

PEARL. A beautiful pearly white flower of perfect formation. Double to the center. The flowers on reach- ing maturity are pure white. A lovely anemone flower.

SATISFACTO. A splendid anemone flowered Mum in tints of old gold and bronze.

SOURCE D'OR. One of the oldest of the anemone flowered types and still one of the best. Color, a magnificent shade of old gold. A superb variety for cutting purposes. Flowers quite large.

SUNSHINE. A very late variety, and, as the name implies, a brilliant golden yellow. A comparatively new sort and one which we can highly recommend.

WESTERN BEAUTY. A splendid double anemone flowered sort. In color, bright rosy lavender. A mid. season variety of great beauty and value.

WHITE ANEMONE. A replica in form, habit of growth, etc., to Yellow Anemone and a fine companion in every way. Flowers pure white, borne in dense compact heads. One of the best of all whites.

YELLOW ANEMONE. A splendid primrose yellow. Flowers of moderate size, quite double. Blossoms pro- 
duced in compact heads. One we can strongly recommend. Moderate in height.

Price of any of the above Anemone types, each 20c; per dozen, \$2.00.

\section{POMPON FLOWERED TYPES}

MARY. Bright lavender pink. A clean uniform color. Very fine for cutting.

AUTUMN TINTS. A handsome moderate size pompon variety, interior of the petals bronzy crimson, exterior old gold. Late flowering. Extra good.

BILLY PRIMROSE. An exquisite and novel color in Pompon Chrysanthemums. A distinct shade of deep tyrian rose. The flower is perfect in contour, sprays well filled. A gem for cutting purposes.

CLARA. A lovely creamy white pompon of the very small flowered baby or button type.

DAVENPORT. A lovely shade of burnt orange and chestnut, somewhat dwarfer in growth than New York and more compact in habit. A fine variety in every sense of the term.

EUGENE LANGUELET. Medium size, pure yellow; a late flowering sort.

GOLDEN WEST. An elegant golden yellow, petals much imbricated, giving the flower a fringed appearance. The blossoms are borne in compact trusses, absolutely perfect in formation. Fine for basket work or for low borders.

GOLDEN CLIMAX. A splendid addition to the yellow class of Pompon Mums. Somewhat taller in growth than Golden West. Bears immense trusses of bright golden yellow flowers. Planted in the garden in borders or beds, it is a mass of pure gold.

LUCY. A brilliant sun flower yellow-a color which is at once intense and effective. A grand sort for cutting purposes.

MRS. FRANK BEU. A minute flowered pompon variety. Bright golden bronze in color. The dainty flowers composing large trusses, scarcely reach a diameter of half an inch. Although one of the smallest of all pompon Mums, it possesses a grace and elegance of unsurpassed beauty. Highly recommended.

NEW YORK. Easily one of the finest of all pompon Mums by way of color. A superb shade of reddish bronze. Flowers of moderate size, freely, produced on well-branched trusses. A gem for cutting.

RITA. A very dwarf free flowering pompon. A lovely shade of chestnut red. The flowers are quite small-almost a replica of Golden Climax in general contour.

Price of any of the foregoing Pompon Mums, each 20c; per dozen, $\$ \mathbf{2 . 0 0}$.

\section{SINGLE TYPES}

CATHERINE LIVINGSTON. Lavender toned with white. Bears four rows of petals surrounding the central disc. Dwarf in habit. Extra good.

DONALD. Flowers semi-double, cream white in color, tinged with lavender. An exceedingly graceful loose formed variety.
DOROTHY DUGAN. A large flowered semi-double form. Pure white tinted cream in the opening bloom. Easily one of the best whites.

EXCELSIOR. A large flowered single. Open blossoms a delightful shade of bronze and flame.

GODFREY'S PINK. Large flowered lavender pink. The blossoms are composed of three or four rows of broad strap-like petals. A great favorite with commercial growers. One of the best.

IRA. A neat compact growing variety. Blossoms produced in densely formed medium sized trusses. In color, a lovely shade of soft rose pink. Very fine.

IRENE. Deep lavender merging to a white zone in the center of the flower. A dwarf variety.

KATHERINE COVELL. Bright purple, about the same shade as that to be noted in the large flowered Mum, Mr. T. Carrington.

LADY LU. A very large flowered, loose petaled single Mum. Informal in shape, exquisite in color and fine for cutting purposes.

LEON GRANT. A superb single variety with broad, flat petaled flowers in a pleasing shade of deep rosy pink. A very good sort.

LITTLE BARBEE. Certainly one of the most exquisite of all single Mums. Blossoms not much larger than some of those of the bigger flowered pompons. The color is a splendid shade of bright canary yellow.

MRS. WM. BUCKINGHAM. A lovely mid-season pink. Has proven itself to be one of the best varieties for cutting or market purposes ever introduced. We cannot too strongly recommend this variety.

MRS. LOU THOMPSON. A beautiful primrose yellow, similar in form to Dorothy Dugan and a fine companion by way of color.

MISS CLARA BANGHART. Bright bronzy crimson. A splendid dark flowered variety.

MARION SUTHERLAND. Bright sun flower yellow of extremely rich effect. Superb either as a variety for cutting or for planting in the garden.

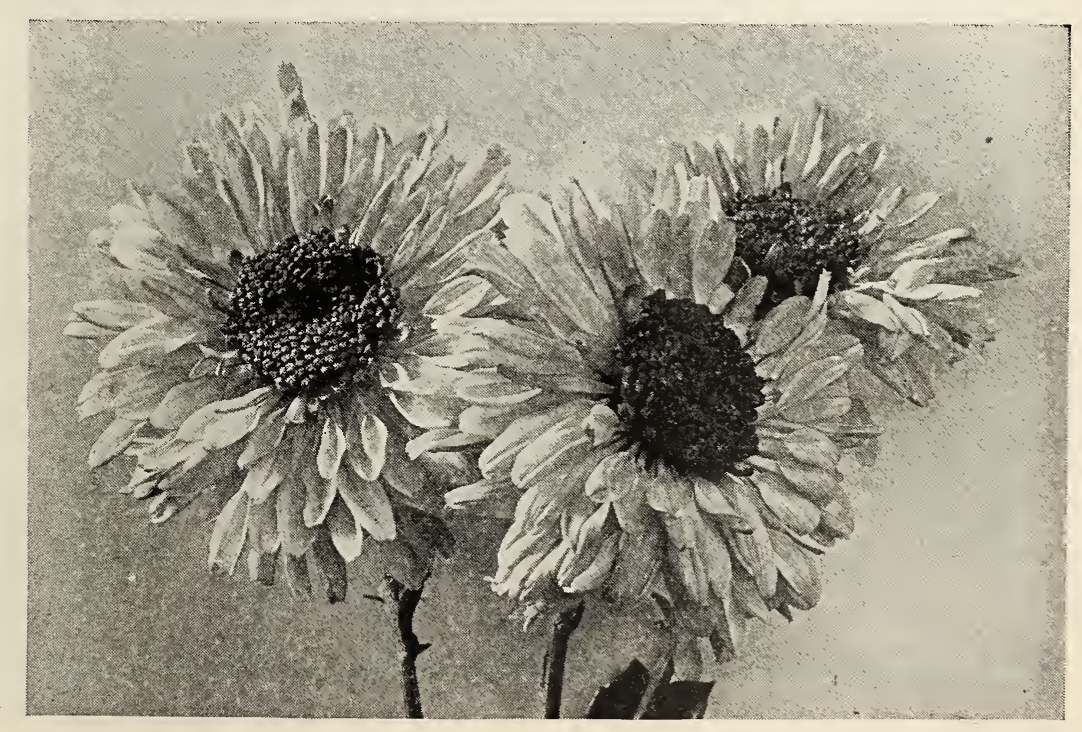

Co-ed 
MINNESOTA. One of the handsomest of all the dark flowered section of single Mums. The color is a bright glowing crimson toned with maroon. Under artificial light the flowers have a glow and sheen which makes them doubly attractive.

PEGGY JOHNSON. Color deep bright canary yellow. A splendid mid-season variety. Flowers borne in dense compact trusses. Plants of medium height. A variety of splendid effect during its blooming season.

R. B. BURGE. Pure snowy white with broad, well arranged petals. A splendid addition to the whites.

RICHARD DELAFIELD. Bronzy crimson with a zone of gold surrounding the center disc. A single variety of great merit.

YVONNE. In color, a pure tone of golden amber. Very free, quite dwarf.

Price of any of the above single Mums, each 20c; per dozen, $\$ 2.00$.

\section{Howard \& Smith's Special Offer of Choice Named Chrysanthemums}

COLLECTION A. 12 very fine Japanese Chrysanthemums. Complete assortment of colors. Strictly our own slection for

$\$ 2.25$.

COLLECTION B. 24 extra choice varieties of Japanese Chrysanthemums, a collection which is representative of the very best varieties noted in the foregoing list. Each different, carefully labeled, strictly our own selection for

$\$ 4.00$.

COLLECTION C. 12 extra choice small flowered Chrysanthemums, including Anemone, Pompon and Singles, in a well-balanced assortment. Strictly our own selection, each a different variety, carefully labeled for

$\$ 1.75$.

COLLECTION D. 24 extra choice small flowered Chrysanthemums, including Anemone, Pompon, and Singles, each different. Strictly our own selection, all the principal colors for

$\$ 3.25$.

\section{CULTURAL NOTES}

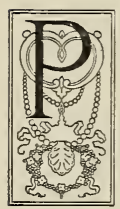

REPARATION OF BEDS. Where it is desired to produce exhibition blooms of the largest size, it is advisable to begin operations early in the season. The beds in which they are to be grown should be spaded over to a depth of flfteen inches and have a liberal dressing of well-rotted manure, thoroughly worked through the soil. Begin the work of getting ready a month in advance of the planting time, putting on the manure after the first breaking up of the bed; give a thorough soaking when this is done, and when sufficiently dry, turn over again.

ARRANGEMENT OF BEDS. The best width for a bed is three feet, with a length to suit the requirements of the garden. A path two and one-half feet wide between the plots is advisable. Rake the beds to perfect grade and construct a narrow ridge five inches high along the sides and end. With this done, we have what is practically a basin for the plants.

PLANTING. With the beds prepared, as above stated, draw two lines from end to end, ten inches from the ridges at the sides; this leaves the lines 16 inches apdrt through the middle of the bed. Along those lines insert, the plants one foot apart.

Planting may be done any time from April 1 to June 15. As a rule, however, the early plants give the best results.

WATERING. If the beds are prepared, as noted above, there is practically a basin to hold the water. Of this Chrysanthemums require plenty, and it should be administered by flooding the bed; lack of water causes hard stems and consequent poor blooms. There is more danger of too little rather than too much water in our dry cliriate. Aim to keep the plants growing freely at all times. Keep the beds moist without being soggy.

STAKING. As soon as the plants are set out, insert a stout post at each end of the row and thoroughly brace same. Between these posts and along the row of plants stretch strong, light wires; the first, one foot above the ground, and others to the number of four, one foot apart above the first. At every five feet between the end posts drive a $1 \times 2$-inch by 6 -foot stake and staple the wires to same at the point they cross. This wire and wood framework should be 5 feet high; the end posts 7 feet long, with 2 feet buried in the ground to sustain the tension of the wire. With the intermediate posts one foot in the ground is sufficient. As the plants grow during the season, carefully tie them with raffia to the wires.

By arranging the plants in long, narrow beds and supporting, as above, they are easy to get at for disbudding. cultivation, etc., and high winds are not liable to break them off.

PINCHING. If allowed to grow unchecked, the plants would reach a height of several feet by Fall. To keep them in bounds they should be cut back once or twice during the Summer, but not later than August 10. Early set plants can be stopped in June and again in August. For late planted stock one pinching back will suffice.

Assuming that the plants have been pinched back to 18 inches in August, an abundance of young shoots will start at once; when these have attained a length of three or four inches select four or five of the strongest and remove the balance.

It is to be remembered that each of the shoots left is to be the flower stem crowned with a large single bloom in the Fall. If more and smaller blooms are desired, more shoots may be left, but the blooms will not have the size or quality, as where fewer are selected. As the new shoots grow very rapidly, keep them well tied up, removing all new side shoots, which may appear in the axils of the leaves. By October these shoots should be nearly four feet high and ready for the final operation.

DISBUDDING. We have here an operation upon which depends the success of the crop and one in which the good judgment of the grower is constantly called upon. In warm seasons the buds, especially the early varieties, of ten make their appearance by September 1st. As soon as they are large enough to handle, select the strongest and remove the balance. It is not always advisable ,however, to leave the larger one at the terminus of the shoot; this often brings a coarse bloom and too early. A second bud lower down, although of smaller size, will produce an equally large bloom, but later in the season. After the bud has been selected. 
keep all side growth pinched out, the idea being to divert the entire flow of sap to the one bud.

MANURES. Chrysanthemums are gross feeders. A liberal mulch of well-rotted manure every two or three months during the growing period aids greatly in the production of the fine foliage, heavy stems and large blooms; it checks the evaporation and keeps the soil cool and moist. Commercial fertilizers, such as bone meal, or blood and bone, are useful in accelerating the growth, but care must be used not to overdo; an ounce or two to the plant dusted over the soil and raked in every two or three weeks during the Summer is sufficient. An overdose will destroy the root action. Discontinue all solid forms of fertilizer when the buds appear, giving only manure in liquid form. Stop this when the petals begin to appear, using water only.

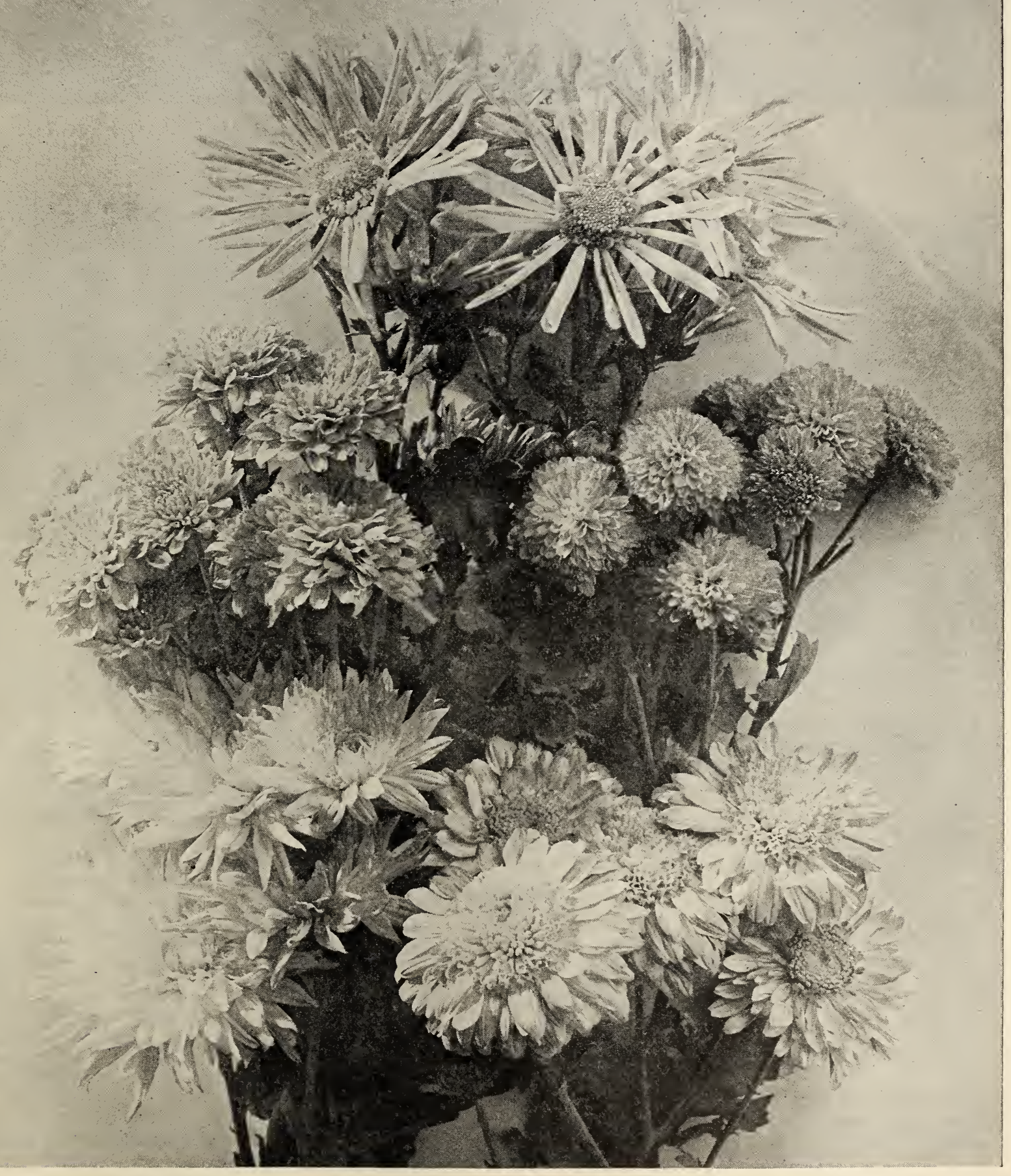




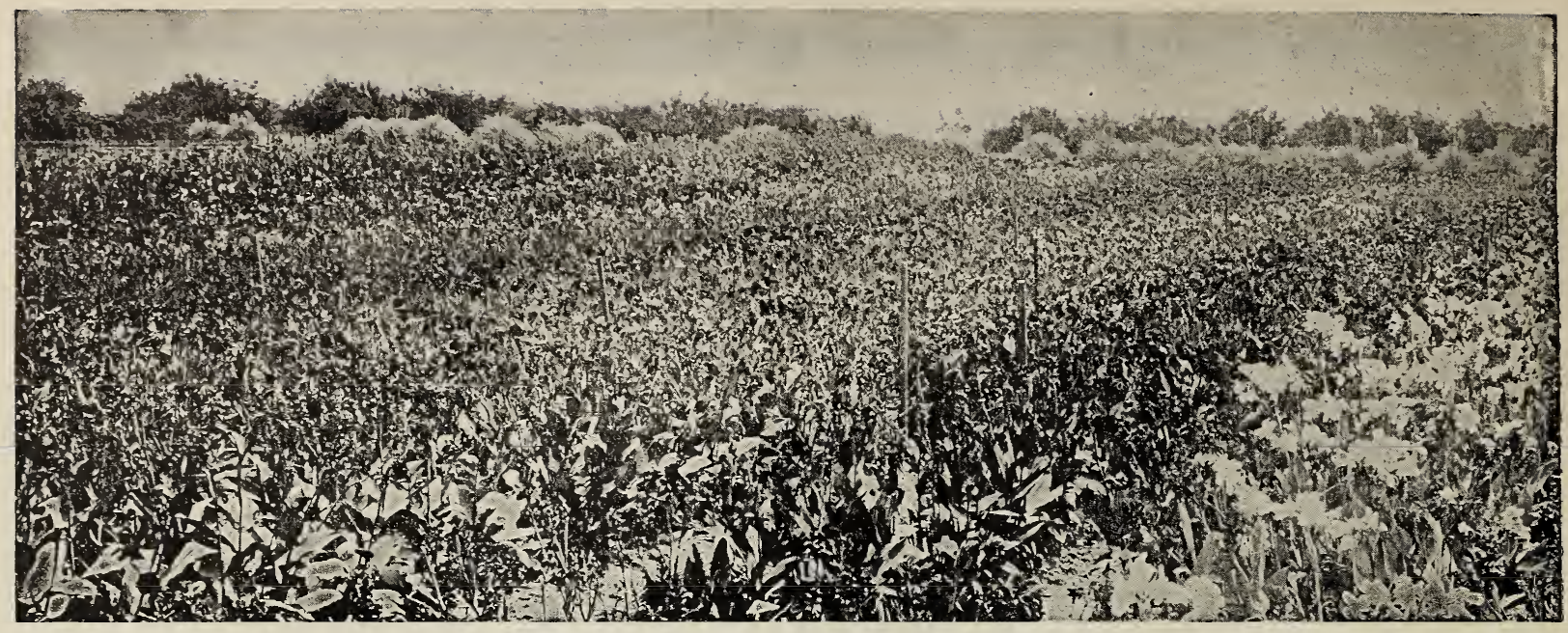

Field View of Block of Cannas at Montebello

\section{Cannas}

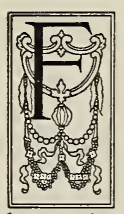

OR RICH sub-tropical effects in the Summer garden, and for a long continued display of bright color, we know of nothing more effective than Cannas. They bloom without intermission from early Summer until the advent of Winter frosts. The mass of color which they produce is constant in its nature. The trusses of bloom follow each other in rapid succession, so that at no time is the plant or bed devoid of blooms. Splendid effects may be obtained by using them in conjunction with the various ornamental grasses, Caladiums, etc. When used in borders, they make splendid background plants and are equally valuable for planting in lawns or other open areas.

\section{Ten Superb New Cannas, The Cream of Recent Introductions}

AMBASSADOR. A superb new bedding Canna with flowers of gigantic size. One which will rank with the variety, Mrs. Pierre S. du Pont, in vigor or growth, size of truss, etc. Foliage rich dark bronze. It is a variety which cleans nicely in the truss. As soon as the flowers are spent, they drop to the ground. In our trials of the past season this Cannas gave one of the most brilliant stretches of color of any variety in the field. It is a full rich crimson, very fine indeed.

Price each 35c.

BALTIMORE. A marked improvement in the dark pink colored section of Cannas. The immense broad petaled blooms and gigantic trusses are borne well above the foliage and is strictly an all season bloomer. Height 4 feet.

Price each 50c.

GOLDEN WEDDING. A very dwarf bedding Canna, brilliant canary yellow in color. Trusses neat and compact. Blossoms of large size and splendid form. A fine variety for a low border. Price each 50c.

KING MIDAS. An even shade of pure golden yellow. As with others in this set, the blossoms are remarkable for their immense size and perfect form. The trusses clean nicely which make it valuable as a bedding Canna. The old blossoms drop as soon as they reach maturity, which always leaves the trusses fresh and bright.

Price each 50c.

MOHAWK. A grand variety from any point of view. Foliage dark bronzy crimson. Quite as dark in this respect as that of the well known variety, King Humbert. Flowers of gigantic size. Rich crimson scarlet in color. Extra fine.
MRS. PIERRE S. DU PONT. Without doubt this peerless variety is the leader of all Cannas in the pink section or for that matter of any other color introduced up to the present time. The foliage is of truly tropical effect, being very broad and long, dark green in color, and offers a beautiful foil for the gigantic trusses of bloom. These latter are poised on large heavy stems and it is nothing unusual for these trusses to attain a diameter of a foot or more. The color, as described by the raisers, is that of watermelon pink, a new color in Cannas, and one which is as beautiful as it is new. We cannot too highly recommend this glorious variety. It is the acme of perfection, attained in Cannas to date. A bed of this in your garden or even a single clump when in full bloom attracts the eye at once. The word "magnificent" scarcely does it justice. Price each $\$ 1.00$

PALM BEACH. A most worthy addition to this splendid list of novelties. It is of immense size, with fully rounded four-petaled blooms The color is an entrancing shade of pearly salmon blush A tall growing variety, attaining a height of some 4 to 5 feet.

Price each 50c.

PRESIDENT. One of the largest flowered Cannas introduced up to the present time. Blossoms of truly mammoth porportions, composed of broad wide open petals. In color, a splendid shade of scarlet. A glorious variety any way you take it.

Price each 35c.

SALMON BEAUTY. For clarity of color, in a pure even shade of deep salmon pink, this is an oustanding variety. The individual blossoms are of enormous size, composed of broad overlapping petals, displaying to great 
advantage its unique and beautiful color. The petals are compact in their growth, medium as to height. The trusses clean nicely, so that a bed of this Canna always presents a charmingly fresh and bright appearance. No other Canna introduced up to the present time has anything like an equivalent color, and it marks a great advance in the improvement of the race. We are positive that this variety will please the most discriminating.

Price each 75 c.

VICTORY. A lovely variety in a unique shade of apricot. Flowers of medium size, trusses large and densely filled.

Price each 50c.

SPECIAL OFFER: One each of the above magnificent new Cannas, 10 varieties in all and truly the last word in Cannas in their present stage of development for

\section{GENERAL COLLECTION}

$\$ 5.00$.

ALFRED MAUTHER. Deep crimson. One of the best.

Price each 25c.

AMERICAN BEAUTY (H. \& S.). A splendid hybrid of our own production. Color, a deep shade of carmine rose of a particularly pleasing and unique shade. Size of both trusses and individual flowers enormous, with the advantage that it cleans nicely in the truss.

Price each 25c.

BRIGHTNESS (H. \& S.). Intense orange scarlet. Flowers of magnificent size and intensely brilliant color. One of the finest bedding Cannas extant.

Price each 25c.

CHARLES LUTZ. A lovely shade of pure yellow. Price each 25c.

EVOLUTION. Salmon apricot color. A fine variety. Price each 25c.

FIREBIRD. Intense bright scarlet. Flowers enormous in size, 8-inch blossoms being quite common.

Price each 25c.

FAISANDORE. Bronze foliage, flowers a beautiful apricot carmine color with golden sheen. Price each 25 c.

GUSTAVE GUMPPER. Deep, rich golden yellow without a trace of any other color. This is one of the finest yellow Cannas in cultivation. Price each $25 \mathrm{c}$

HUNGARIA. Delicate rose pink. A gem in every way.

Price each 25c.

HERZOG VON OTRANTE. Yellow with center of bloom deep brownish crimson.

Price each 25c.

KING HUMBERT. A bronze foliage variety with reddish scarlet flowers. Enormous in size and a great favorite.
LA FRANCE (H. \& S.). A magnificent Canna in every way. Tall growing with immense flowers and trusses of a clean, even shade of pure pink. One of the finest things in our collection.

Price each 35 c.

LUDWIG KOPF. Bronze foliage. Flowers a beautiful orange and apricot color.

Price each 25c.

MAD. SIEBRECHT. Yellow penciled brownish red. Price each 25c.

MRS. A. F. CONARD. Pure salmon pink with very fine foliage.

Price each 25c.

OISEAU D'OR (Goldbird). A beautiful shade of canary yellow. The immense flowers are borne in large trusses above the heavy green foliage.

Price each 25c.

OLYMPE. Rich carmine rose shading lighter towards the center.

Price each 25c.

PRINCE WEID. Rich brilliant crimson.

Price each 25c.

QUEEN HELEN (Yellow King Humbert)....A splendid Canna, a sport from that well known variety, King Humbert, but differing entirely in color. The flowers are enormous size and a deep, rich yellow color, hand-

Price each 25c.

RICHARD WALLACE. Bright canary yellow.

Price each 20c.

ROSEA GIGANTEA. A pretty shade of carmine rose.

Price each 20c.

SAN DIEGO. This variety is a distinct shade of burnt orange. The individual heads and trusses are of immense size and the trusses clean nicely. It is quite a new color in Cannas and one, when it becomes better known, will, undoubtedly, be in great demand.

Price each 35c.

STUTTGARDIA. Orange scarlet edged golden yellow, marbled light scarlet.

Price each 25c.

\section{CULTURAL NOTE}

The principal points in the cultivation of Cannas necessary for the most perfect development of plant and bloom may be expressed in a very few words: They are Summer heat, manure, and an abundance of water. Cannas are too often neglected because of their ease of growth, and yet there is not a plant grown which will respond more quickly to liberal treatment or show a more marked improvement in quality of bloom when attention is given them.

\section{Heliotrope}

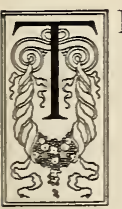

HE VARIETIES of Heliotrope, which we offer you, comprise a splendid range of colors and belong to the giant flowered class. The trusses on well grown plants often attain a foot in diameter. Heliotropes are splendid subjects for sunny beds. They delight in a rich, moist soil and fully exposed position. As an edging plant to shrubbery borders, or in mass planting by themselves, they are very effective and their delicious fragrance appeals to everyone.

CENTEFLEUR. Trusses of enormous size, dark rich violet in color.

LUEUR d' OPALE. A superb shade of pale blue.

Trusses of extraordinary size.

MADAM BRUANT. A distinct shade of light purple, of splendid dwarf habit.
SNOW WREATH. The best of all pure white Heliotropes. The trusses of bloom show a lavender suffusion.

TALL DARK. Rich, deep purple flowers. A very vigorous, tall growing variety.

Fine, strong plants of any of the above.

Each, 25c; doz. $\$ 2.50$. 


\section{Phlox}

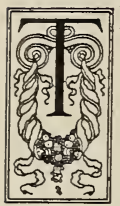

HESE old-fashioned plants in their new and improved types, make one of the most impressive displays of color that it is possible to obtain in the garden. They are indispensable subjects for the herbaceous border, producing a continuous display throughout the Summer and Autumn months. Once planted they last for several seasons as the plants are truly perennial in their nature. As a general thing they may be left undisturbed over a period of three years, after which time it is advisable to divide the clumps and re-set them. This should be done after their Fall blooming period or in early Spring before growth begins.

We produce each season at our Rivera nursery thousands upon thousands of these plants. The fields, when in bloom, are a sight worth a trip of miles to see. From November until April, Phlox can be handled in a dormant or bare root condition. They pack light and can be shipped to distant points at very small expense. They withstand heat and extremes of cold. There is not a State in the Union where they will not thrive if given ordinary attention. With the return of each season you can have a wonderful display of handsome heads of bloom.

AUSTRALIA. A comparatively new Phlox bearing immense florets. Color, a remarkable shade of crimson purple. Height 2 feet.

Price each, 25c.

ALBION. A vigorous growing variety, pure white, with pale pink eye. Height 2 feet. Price each, 25c.

B. COMTE. A beautiful shade of purple overlaid with crimson, with a very dark eye. A good, vigorous growing Phlox; one of the best of its grade. Height 2 feet.

Price each, 25c.

BACCHANTE. Dark rose with highly contrasting carmine eye. Height 2 feet.

Price each, 25c.

BRIDESMAID. A distinct and beautiful sort, pure white, with a well-defined crimson eye. Height 18 inches.

Price each, 20c.

CREPUSCULE. White ground suffused mauve, eye rosy purple. Height 2 feet.

Price each, 25c.

DEUTSCHLAND. A recent introduction in Phlox and unquestionably one of the finest which has come to our notice in a long time. The color is a brilliant shade of Oriental red, with a highly contrasting rich crimson red eye. Very fine.

Price each, 35c.

ECLAIREUR. Deep wine red. Height 2 feet 6 inches. novel and distinct color.

Price each, 25c.

ELIZABETH CAMPBELL. The peer of all pink Phlox. Soft rose pink rayed with white. Dark rose colored eye. Individual florets, immense in size. Trusses very large. A scarce and much-sought-after variety. Height 18 inches.

Price each, 25c.

EUROPA. An immense head composed of extra large flowers, pure white in color, with a highly contrasting center eye of dark carmine.

Price each, 25c.

F. A. BUCHNER. Intermediate in height, betwe $\circ$ n Mrs. Jenkins and Mad. Marie Kuppenheim. Nearly pure white in color. Height 2 feet.

Price each, 20c.

GEN. VON DIEDEM. One of the most brilliantly colored Phloxes in our entire collection. Rich dark saimon scarlet in color. Bears immense heads. Very fine, indeed.

Price each, 35c.

GOLIATH. A tall growing large flowered bright orange scarlet Phlox. Lighter in color than Vesuvius. A bright and telling color.

Price each, 25c.

HENRY MURGER. Pure white, with a dark eye, a distinct and beautiful sort.

Price each, 25c.

HERVOR. A pure even shade of rose with a white eye. Bears splendidly formed trusses. Price each, 25c.

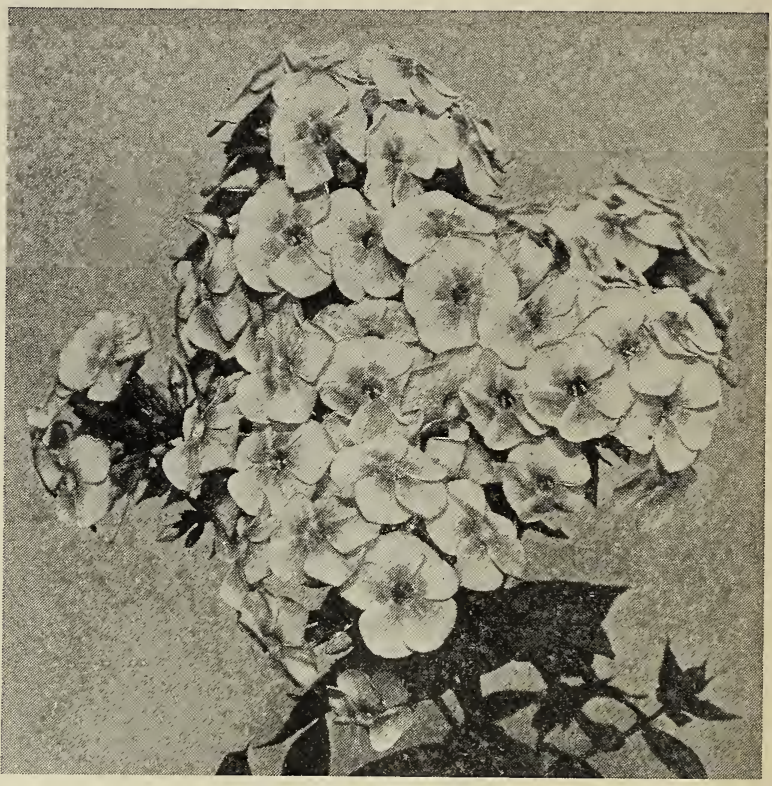

Henry Murger

LOUISE ABBEMA. White ground shot with rose. Florets of moderate size. Trusses large and compact. Height 18 inches.

Price each, 25c.

LA VAGUE. Florets of moderate size, borne in large trusses. In color a delicate shade of soft pink. Height 2 feet.

Price each, 25c.

PANTHEON. An elegant shade of bright rose pink with a distinct dark eye. A beautiful variety.

Price each, 25c.

MAD. MARIE KUPPENHEIM. A splendid front row Phlox. One of the best dwarf pure whites. Height 15 inches.

Price each. 25c.

MAD. PAUL DUTRIE. A charming shade of pure flesh pink overlaying a white ground. Price each, 25c.

MRS. JENKINS. One of the oldest Phloxes in cultivation and still one of the best pure white varieties in commerce today. Attains a height of 2 to $21 / 2$ feet. Trusses immense, conical in form; a particularly good one.
Price each, 20c. 


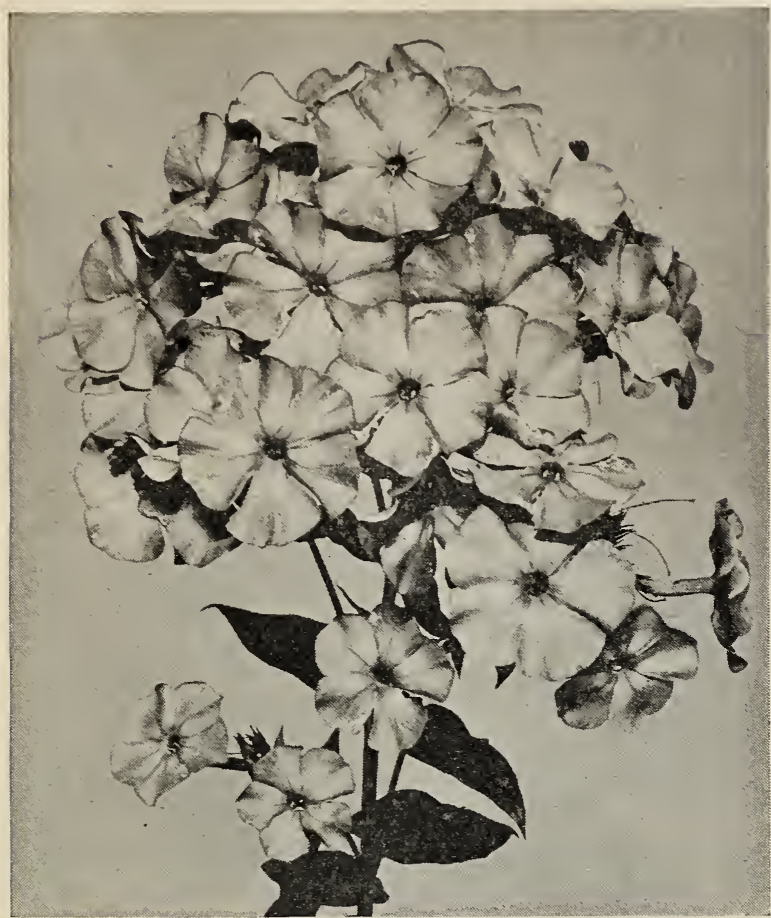

Goliath

OBERGARTNER REICHENAU. Extra large flowers, bright rose. Strong, compact grower; extra heavy foliage. A good grower. Very desirable. Height 2 feet.

Price each, 25c.

PROF. SCHIELEMANN. The florets of this Phlox are of moderate size. In color a beautiful shade of lilac rose, trusses more or less conical in form. Growth tall. A fine back row variety.

Price each, 20c.

PROF. VIRCHOW. A soft pearly pink with distinct crimson eye. An especially delicate shade. Height 18 inches.

Price each, 25c.

RHEINLANDER. A beautiful salmon pink, the center of each floret relieved with a distinct carmine crimson eye. Height 18 inches. Blossoms and trusses of very large size.

Price each, 25c.

RYNSTROM. A superb shade of dark salmon rose. Florets of immense size, growth compact. Trusses immense. Easily one of the finest Phloxes of its color. Height 18 inches.

Price each, 25c.

SELMA. A clear, bright rose highly relieved with a distinct carmine crimson eye. One of the best of all Phloxes of this color. Flowers of superb size. Trusses immense. Height 2 feet.

Price each, 25c.

VESUVIUS. A dwarf Phlox bearing large trusses of bright fiery crimson flowers. Height 15 inches

Price each, 25c.

WANADIS. A very desirable variety. Bears immense trusses with large individual florets. The color is unique in this class of plants, being a delicate shade of lilac, the center of each floret having a bluish purple eye Height about 18 inches. Extra fine. Price each, 25c.

WIDAR. An exquisite two-toned Phlox bearing florets of immense size. Color lavender, rayed with white.

Price each, 25c.
HOWARD \& SMITH'S S PECIAL Offer of Choice Phlox

COLLECTION A. 12 very fine Phlox from the collection noted above, our selection, each one different, carefully labelled, suitable for a small garden, \$2.50.

COLLECTION B. 24 superb Phlox from the collection noted above, our selection, each one different, carefully labelled, suitable for a garden of moderate size.

$\$ 4.75$.

COLLECTION C. The complete collection of the above Phlox, a collection of which is may be truly said is the last word in Phlox today, fine strong plants, each carefully labelled.

$\$ 6.50$.

\section{CULTURAL NOTE}

Although perennial Phlox are of the easiest possible culture, they are a subject which respond readily to good cultural methods. In general they delight in a light, rich loamy soil. They are gross feeders and require an abundance of well-rotted manure worked into the soil -this operation to be done preferably some time prior to planting.

There is a vast difference in the quality of the plants where they have been afforded liberal treatment as against being planted in poor or impoverished soil. During dry weather they require an abundance of moisture and water in generous amounts should be given when they show the slightest signs of flagging.

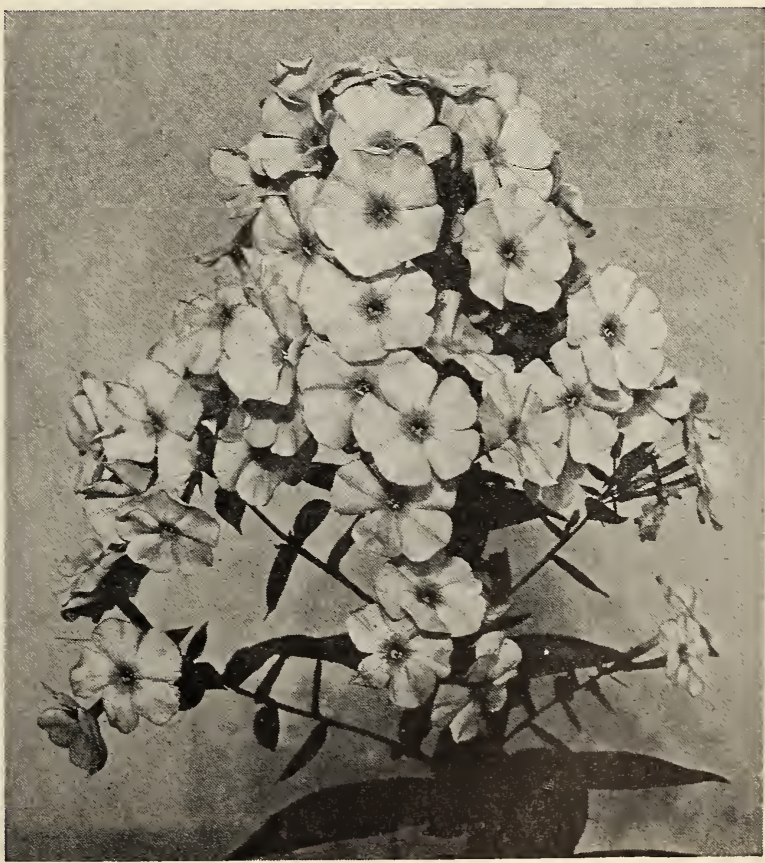

Selma 


\section{Carnations}

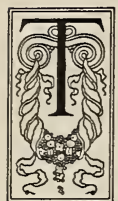

HE REFINED form, the exquisite fragrance and the free blooming qualities of the Carnation place it in a position which, in popular fa vor, is second only to the rose. Carnations can be grown with ease in any garden with the simplest methods of culture. The perpetual type of carnation, such as those we offer you, bloom without intermission throughout the year and insure at all times a bountiful supply of fragrant blooms for the decoration of the home.

AVIATOR. Bright, soft scarlet, makes plenty of grass, free and branching in character. Produces immense quantities of blossoms over a protracted period. Price each, 15c; per doz., \$1.50.

BELLE WASHBURN. A pure, even shade of bright scarlet. Has wonderful stems, good calyx and all the other attributes of a good carnation.

Price each, 15c; per doz., \$1.50.

ESTELLE. Deep reddish scarlet. Flowers of large size, splendid as to stem and calyx. One of the best of its color.

Price each, $15 \mathrm{c}$; per doz., $\mathbf{\$ 1 . 5 0}$.

ENCHANTRESS. Flowers of enormous size; an exquisite shade of shell pink in color. Standard variety everywhere.

Price each, 15c; per doz., $\$ \mathbf{1 . 5 0}$.

HARLOWARDEN. Dark, rich crimson maroon. Like most carnations of its color, the fragrance is intense.

Price each, $15 \mathrm{c}$; per doz., $\$ \mathbf{1 . 5 0}$.

"LADDIE." Unquestionably one of the finest of all Carnations. Although introduced several seasons ago the plants are always scarce, due to the fact that it flowers so freely that but few cuttings are available for propagating purposes. Disbudded stems of this Carnaions will produce flowers $4 \mathrm{~T} / 2$ inches in diameter. It is not only a variety remarkable on account of its size, but also for its unusual color, the latter being a soft shade of salmon rose. The stems are of great length and stiff in character. In planting this novelty Carnation one may be assured of beauty unrivaled in any flower of its class. $\quad$ Price each, 25c; per doz., \$2.50.

MATCHLESS. A top notch white Carnation. Remarkable alike for the immense size of its blooms, its vigorous growth and intense fragrance.

Price each, 15c; per doz., $\$ 1.50$.

MRS. C. W. WARD. One of the standard varieties for commercial cut flower growers. Rich rose pink in color; perfect as to calyx, with good stem.

Price each, 15c; per doz., $\$ \mathbf{1 . 5 0}$.

ROOSEVELT. Rich crimson maroon, not unlike the color to be noted in the old-fashioned clove pink. Intensely fragrant.

Price each, 15c; per doz., $\$ \mathbf{1 . 5 0}$.

SPECTRUM (NEW). An immense flowered light scarlet Carnation with beautifully crimped and fringed petals and intensely fragrant. This Carnation although of immense size, has a perfect calyx which never bursts. The flower is of ideal form and is borne on strong, rigid stems. A grand variety for cutting purposes. Price each, 25c; per doz., $\$ 2.50$.

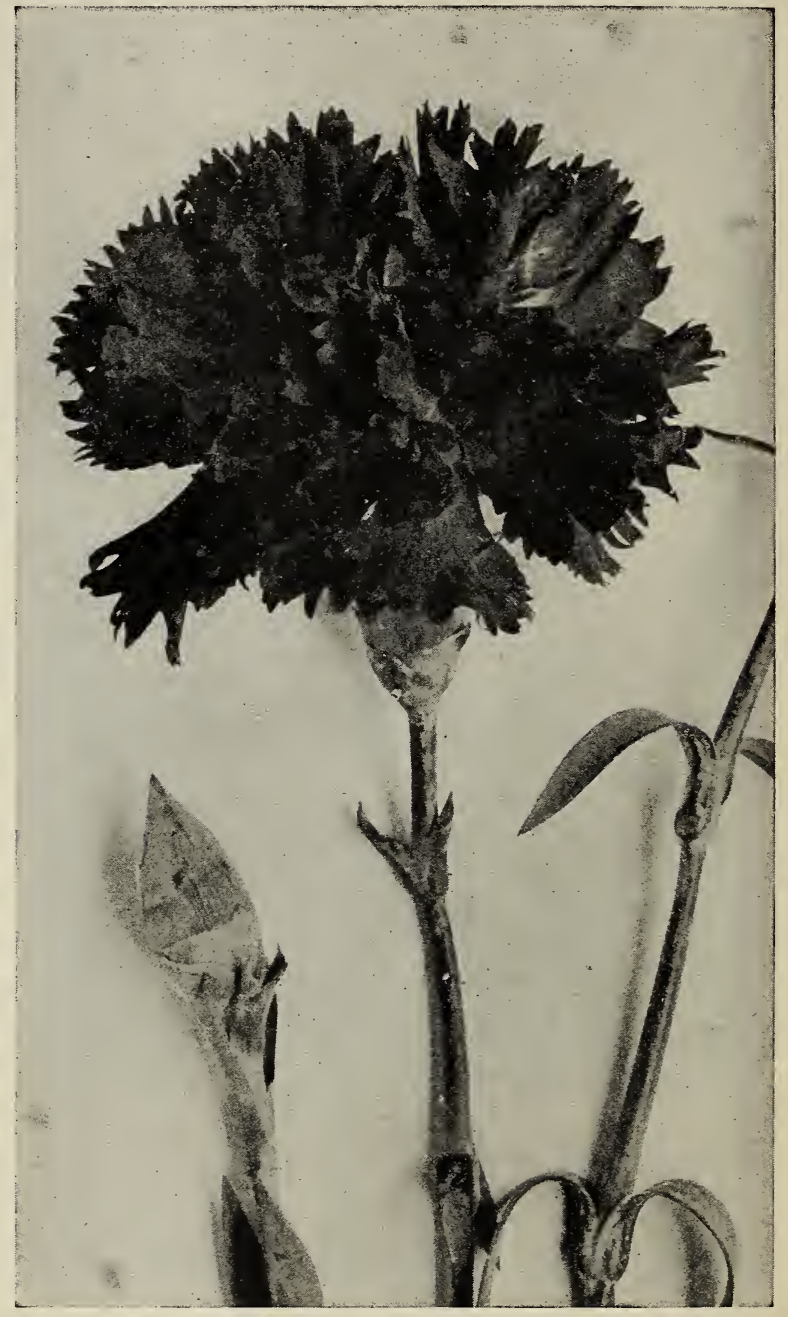

Carnation Belle Washburn

\section{CULTURAL NOTE}

Carnations prefer loamy soil, which has been well enriched with rotted manure. The position for the beds should be in full sun away from buildings, where the refracted sun's rays burn and destroy the beauty of the flowers. Plant in rows $21 / 2$ feet apart, with the plants 15 inches apart in the row. This arrangement allows for liberal cultivation and irrigation by small trenches along both sides of the row. They do far better under this system of watering than when sprinkled; the flowers do not become spotted and the plants grow vigorously.

To obtain the largest-sized blooms, remove when quite small all the lateral buds, leaving only the terminal. 


\section{Hydrangeas}

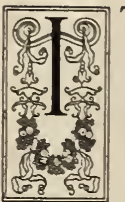

T IS with pleasure that we direct the attention of our customers to the splendid collection of Hydrangeas noted below. With the exception of the variety Otaksa they are all hybrids of French origin and have created a sensation wherever they have been shown. Until the advent of these new hybrids the colors in Hydrangeas were confined to either pink or white, whereas in this new set an immense range of charming colors have been added. The trusses and blooms of nearly all of the sorts are of phenomenal size. The fact that Hydrangeas thrive in shady places makes them especially valuable in north borders, etc., where only too often it is difficult to obtain definite or permanent color effects.

ARBORESCENS GRANDIFLORA. A deciduous pure snow white Hydrangea bearing enormous trusses of bloom of much the same type as those of the hortensis class, but with foliage more or less like Hydrangea paniculata. This variety blossoms in late Spring, at which time the plants are covered with immense panicles of snow white flowers. Strong plants from 5-inch pots.

Price each, 75c.

BOTANISTE POLTEREAU. A pretty shade of mauve rose.

Price each 35c.

FRAICHEUR. White with dainty suffusions of rose. $A$ very pleasing combination. Price each 35c.

LA LORRAINE. Pale rose turning to bright pink. Price each 35c.

MLLE. DE TREMAULT. A pure white of distinct form. Extra good.
Price each 35c.
MLLE. RENEE GAILLARD. Pure white with fringed florets.

MAD. E. MOUILLERE. A variety with trusses and individual florets of phenomenal size. White, occasionally tinted with pink.

Price each 35c.

MAD. A. RIVERAIN. Brilliant blush rose. each 35c. ORNAMENT. Extra large flowers. Mauve pink 35c. OTAKSA MONTROSA. One of the older varieties. Always good. Color blush pink. Trusses extra large.

Price each 35 c.

"TROPHEE." A superb new variety distinct in every particular from any Hydrangea hitherto introduced. The color is a brilliant shade of carmine rose-the nearest approach to a red to be noted in this class of plants. Easily one of the finest novelties in any class of plants of recent introduction.
Price each, 50c.

\section{Lantanas}

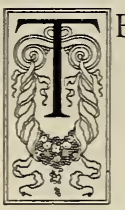

AMIEL. Red, shading to orange.

CRUSALLIS. Bright orange yellow.

CICERONE. Old gold and copper.

IOLANDE. Burnt orange and red.

JANNIA. A pleasing soft pink.

FARFADET. Orange and copper.

RADIATION. Rich red.

ROSE QUEEN. A superb new sort of our own raising. The color is a pleasing shade of rose with a distinct white eye.

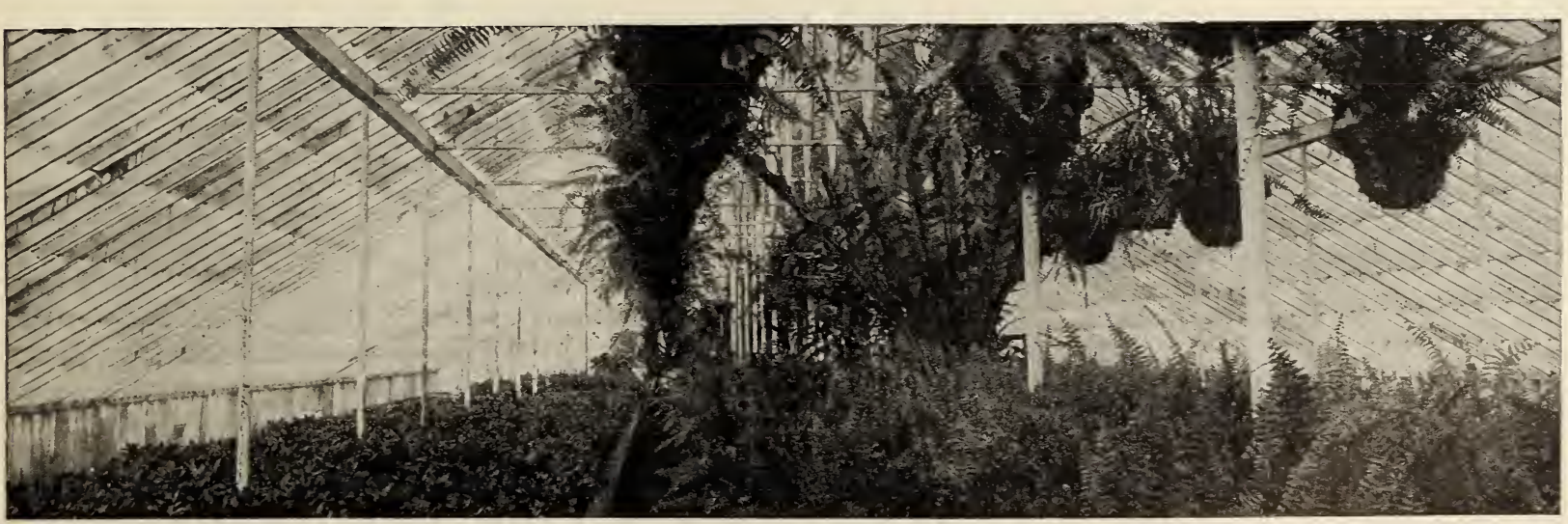

SNOW QUEEN Pure white.

SERAPHINE. Rose pink, merging to orange.

TETHYS. Sulphur yellow.

Price of foregoing varieties: Each, 15c; per doz., \$1.50; per $100, \$ 10.00$.

LANTANA DELICATISSIMA. The well known trailing Lantana. Covered with myriads of beautiful lavender pink flowers. Ideal for basket work or as a ground cover in warm, sunny locations.

Price each, 15c; per doz., \$1.50.

A Greenhouse at Montebello 


\section{Fuchsias}

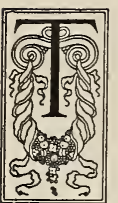

HE COLI.ECTION of Fuchsias which we offer below is second in quality to none in America. They are varieties which we have gathered from all sources and will be found not only distinct in character, but remarkable for the enormous size of the individual blossoms and their splendid free-blooming habit.

Fuchsias do well in any protected north border and bloom in great profusion during the warm months of the year. They should have a well prepared bed which has been thoroughly enriched with well-rotted manure, and copious supplies of w ater during hot weather.

\section{CHOICE DOUBLE VARIETIES}

ANDRE LE NOSTRE. A superb large flowered free blooming variety, very double. The corolla is a beautiful shade of prune blue.

Price each, 35c.

BARON KETTELER. A giant flowered, deep rich purple variety, with distinct scarlet sepals.

Price each, 35c.

BERANGER. Dark purplish blue with distinct red sepals. Very fine.

Price each, 35c.

DIAMANT. A superb white variety, the corolla being streaked with rosy carmine. Enormous flowers.

Price each, 35c.

DR. BEHRING. Bluish purple corolla. Sepals pink. A superb variety.

Price each, 35c.

DOLLAR PRINCESS. Corolla purple. Sepals pink. Very free blooming.

Price each, 35c.

EMILE LAURENT. Rose with handsome white corolla. Clear rose sepals.

Price each, 35c.

GENERAL D' AMADE. Corolla dark rosy pink. Sepals pink. Extra large.

Price each, 35c.

G. PORTESI. Violet blue with veinings of scarlet in the corolla. Price each, 35c.

GRAPHIC. Deep violet purple. Sepals scarlet.

Price each, 35c.

JARRY DESLOGES. White with distinct shading of rosy carmine at base of petals.

Price each, 35c.

JULIETTE ADAMS. A remarkably free flowering double white. Quite distinct from other whites of this set.

Price each, 35c.

LE ROBUSTE. Violet blue, veined with dark rose. Price each, 35c.

LUCIEN DANIEL. A superb shade of mauve. Sepals light red. Extra choice. Price each, 35c.

MONSIEUR MORLIERE. Giant violet purple.

Price each, 35c.

PYTHAGORE. Dark red sepals. Large, handsome violet colored corolla.

Price each, 35c.

PAUL CAMBON. Carmine red sepals. Bluish purple corolla.

Price each, 35c.

RENAULT MORLIERE. Deep prune color. Enormous flowers.

Price each, 35c.

ROSE PHENOMENAL. A superb shade of rosy lavender. A gem.

Price each, 35c.

TORPILLEUR. Corolla flesh with distinct shading of rose. Sepals red.

Price each, 35c.

YVES DELAGE. Corolla prune color. Sepals wine red.

Price each, 35c.

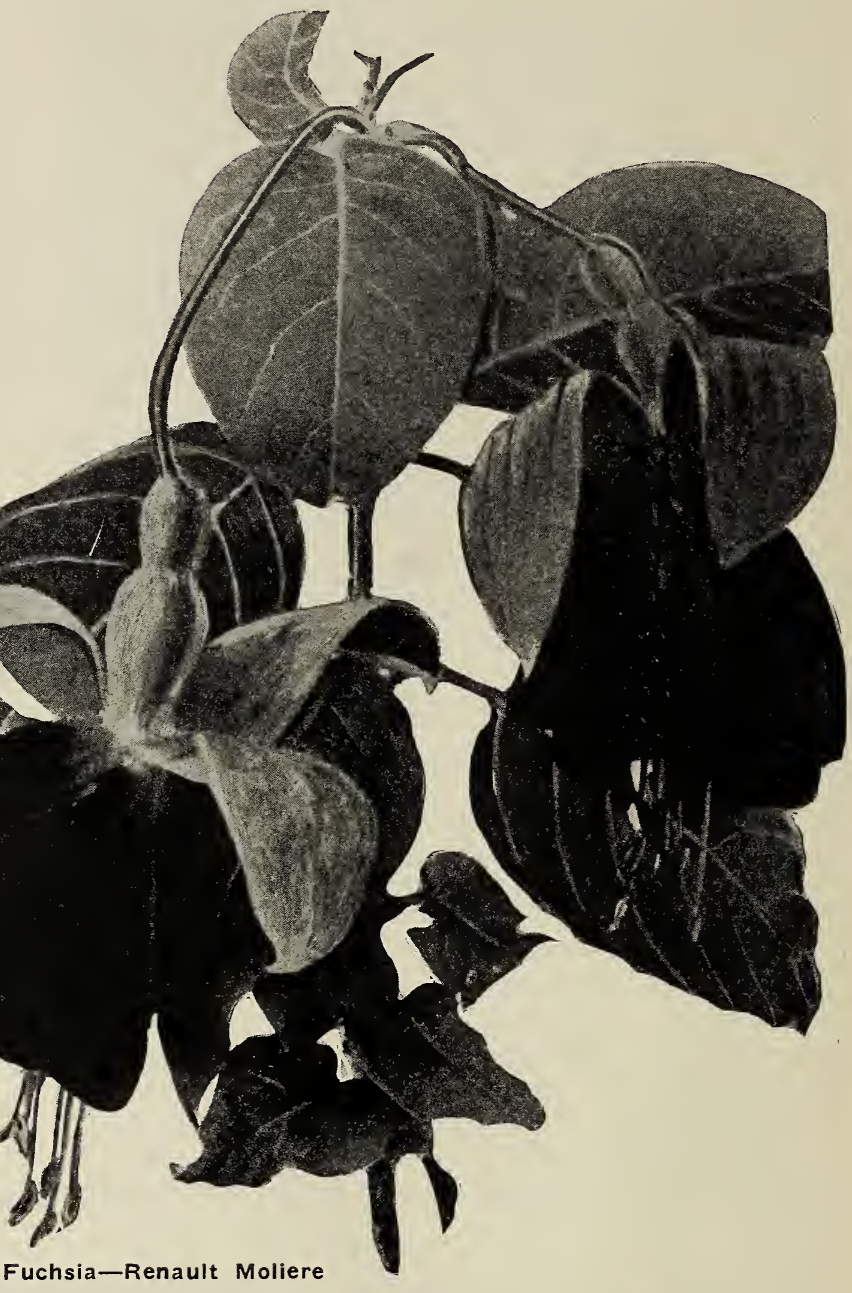

\section{Choice Single Varieties}

BLACK PRINCE. Rich rose colored corolla with scarlet sepals.

Price each, 35c.

ELSA. Corolla rosy purple. Sepals rose color.

Price each, 35c.

SENSATION. Corolla rose pink, tinted with violet.

Carmine red sepals.

Price each, 35c.

SOUVENIR DE HENRY HENKLE. A hybrid of the triphylla class with blossoms some 3 inches long, borne in clusters. Large prune colored foliage.

Price each, 35c.

SWANLEY YELLOW. A beautiful single variety, similar in form to the preceding, with extra long tube and spreading sepals. A distinct shade of orange red.

Price each, 35c. 
BABY FUCHSIAS. These so-called Baby Fuchsias are handsome miniature flowered forms resulting from crosses made between Fuchsia Riccartonii and some of the larger flowered types. They are very vigorous growers and in the southern sections of California often attain a height of 8 to 10 feet when planted in the open ground. They produce a wonderful profusion of small, dainty flowers that completely cover the plants. If planted in north borders, as a background, they are of superb effect. We secured these varieties from France, where they are exceedingly popular for the purposes above mentioned. They are of splendid use also, if planted in tubs or pots, as porch plants. We are only giving short descriptions of these varieties, but all are distinct either as to form or color.

BEAUMARCHIAS. Purple.

CARMEN. Violet.

ELYSEE. Rose pink and white.

L'ENFANT PRODIGUE. Violet purple.

MINOS. Dark purple

MRS. JOSEPHINE FRANKENFIELD. White.

NESTOR. Royal purple.

RONSARD. Violet.

TELEGRAPH. Purple.

Price of any of the above varieties.

Each 25c; per doz. \$2.50.

\section{CULTURAL NOTE}

Fuchsias are primarily moisture loving subjects. The original species from which the hybrids above noted were raised are principally natives of Central and South America. The country to which they are indigenous is one where an abundant rainfall occurs during the various months of the year. Although most of the species are tropical or semi-tropical in their nature it has been demonstrated that they are amenable to both indoor and outdoor culture in the temperate zones.

There are but few subjects which will give better results planted in a north shady position than Fuchsias. They grow with great rapidity and blossom without intermission from early Spring until late Autumn. The number of plants which will grow and blossom profusely in a north exposure are comparatively few. Fuchsias are one of the subjects which require this particular condition. They may be grown as single specimens trained to pyramidal form or they may be trained as standards on single stems. Planted early in Spring and given an abundance of moisture, with liberal feeding, they grow with great rapidity and soon become with only a nominal amount of care plants of splendid effect and beauty. Bear in mind that they are gross feeders. They require a rich soil, and if the soil is at all poor, a liberal mulch of well-rotted manure, with cow manure as a preference, is needed.

\section{Verbenas}

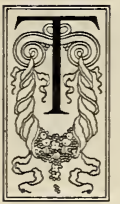

HERE are but few plants more desirable for bedding purposes than Verbenas. They produce a bright and lasting mass of color through the major portion of the year. You will find the named varieties to be noted below exceedingly choice. They are all of the mammoth flowered class with individual blossoms and trusses of enormous size.

We would particularly call your attention to the new variety, "Crimson King." This offers a distinct advance over any other Verbena. It is the result of a series of crosses made at our Montebello trial grounds. There is nothing in existence to equal it for size, beauty of color, or free blooming qualities. Superb for bedding purposes and blossoms right through the season.

BEAUTY OF OXFORD. A very large flowered light rose-colored Verbena. Individual trusses and blossoms of immense size. This variety is a gem for bedding purposes. Very fine.

Price each, 15c; per doz., \$1.50.

CRIMSON KING (Howard \& Smith). The largest flowered Verbena in existence. The individual flowers in the truss will cover half a dollar. It has a color unequalled by any other Verbena we have ever seen, being one of those deep, glorious crimsons that catches the eye at once. It is a gem for bedding or parking purposes, producing a constant sheet of bloom from Spring until late Autumn. It is a tremendous grower with deep green foliage. It is something of superlative quality-something which will please. Price each, 15c; per doz., \$1.50.

ELLEN WILMOTT. Unquestionably the best of all deep rose colored Verbenas. Flowers and trusses of splendid size, with a color tone of charming effect. Price each, 10c; per doz., $\$ \mathbf{1 . 0 0}$.

PURPLE KING. A vivid bluish purple and unquestionably the best of its color.

Price each, 15c; per doz., $\$ 1.50$.
LAVENDER QUEEN. This variety is also the result of our crosses. The color is a beautiful shade of pure lavender. Trusses extra large. One of the best lavender colored Verbenas.

Price each, 15c; per doz., $\$ 1.50$.

MRS. CLEVELAND. The nearest approach to a pure white in the extra large mammoth flowered Verbena. This is a fine companion to other giant flowered varieties of this set. Remarkable in size of truss with immense indivdual florets. Price each, 15c; per doz., \$1.50.

HOWARD \& SMITH MAMMOTH MIXED VERBENAS. Aside from the separate varieties which we offer above and which must be propagated by cuttings, as they do not seed, we would call your attention to this strain, which are free seeders, very large flowered and excellent for mixed bedding purposes. Where no definite color effect is required these Verbenas will be found particularly useful. The plants bloom within a short time after being planted out and continue from early Spring until late Autumn, producing an unbroken carpet of rich and varied colors. Strong plants from 2 -inch pots ready March 1st. 


\section{Geraniums}

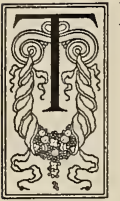

HE ZONAL Pelargoniums, more commonly called Geraniums, are of so much value as flowering decorative plants almost through the entire year that they commend themselves to all who possess a garden and who enjoy the superb stretches of color obtainable with them. There are few plants grown which offer such an uninterrupted display of bloom over an extended period. The newer and improved types are exceedingly fine and where given the most ordinary attention may be depended upon to produce unbroken sheets of color from early Spring to late Autumn.

\section{A Choice Selection of the Best Single Types}

ALICE OF VINCENNES. A splendid variety. Pure white, merging through carmine rose to intense scarlet at the outer edges of the petals.

Price each, 15c; per doz., $\$ \mathbf{1 . 5 0}$.

CRABBE. A mammoth flowered variety. In color a beautiful shade of salmon pink. Remarkable for its gigantic trusses.

Price each, 15c; per doz., \$1.50.

COUNTESS OF JERSEY. A lovely new single Geranium of beautiful salmon pink tone with distinct white eye.

Price each, 20c; per doz., $\$ \mathbf{2 . 0 0}$.

FRED BEAN. Bright salmon pink. Remarkable for its immense blossoms and splendid free blooming qualities.

Price each, $15 \mathrm{c}$; per doz., $\mathbf{\$ 1 . 5 0}$.

HALL CAINE. An ideal bedding Geranium bearing trusses and florets of immense size. Growth is compact. Plants much branched and produces during the Summer season splendid stretches of color. At our trial grounds during the past season it is one of the most admired in our entire collection. The color is a lovely shade of soft glowing scarlet. This Geranium is destined to fill a long felt want in a dwarf variety, being distinct in color and foliage, uniform in bloom and growth, and

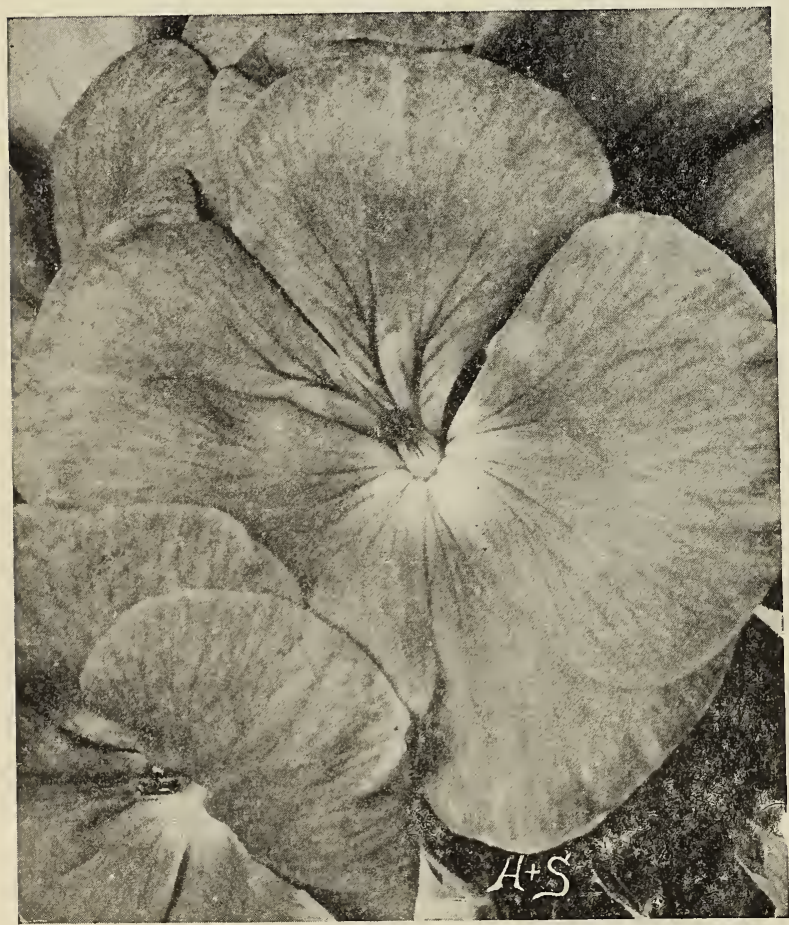

Hall Caine a universal favorite among Geranium admirers. It also makes a splendid pot plant.

Price each, 20c; per doz., $\$ 2.00$.

HERRICK. A dwarf growing, compact habit variety. Flowers intense scarlet. A splendid bedder.

Price each, 15c; per doz., $\$ \mathbf{1 . 5 0}$.

JACQUERIE. Probably the finest dark crimson single Geranium in existence. The mammoth flowers are ideal in form and have that rich, velvety crimson scarlet color that is admired by everyone. For bedding it is unsurpassed.

Price each, 15c; per doz., $\$ \mathbf{1 . 5 0}$.

JOHN FORBES. Bright orange scarlet with immense circular flowers and gigantic trusses. Growth is dwarf and bushy. $\quad$ Price each, 15c; per doz., \$1.50.

L'AUBE. Unquestionably one of the finest of all single white Geraniums. Color, pure snowy white.

Price each, 15c; per doz., \$1.50.

MARY SEATON. Large flowered scarlet with distinct white eye.

Price each, 15c; per doz., \$1.50.

MAXIME KOVALESKY. An unusual color in Geraniums and easily one of the most striking extant for bedding purposes. It is the nearest approach to orange to be found in this class of plants. A bed in bloom conveys the impression of a mass of deep orange colored bloom. It is a variety of exquisite effect when grown by itself. It is not only unusual as to color, but has all the attributes necessary to a good Geranium. The trusses clean nicely and the general appearance of the plants is always bright and fresh. One of the most distinct advances in this class of plants in modern times.

Price each, 20c; per doz., $\$ \mathbf{2 . 0 0}$.

PRESIDENT McKINLEY. Purplish crimson. Flowers exceedingly large. Price each, 15c; per doz., \$1.50.

GERTRUDE PEARSON. Unquestionably one of the finest of all pink Geraniums for bedding purposes. In color, pure rose pink with large white eye.

Price each, $15 \mathrm{c}$; per doz., \$1.50.

GENERAL LEONARD WOOD. Center of flower white, edges broadly banded with rosy carmine. A splendid variety.

Price each, $15 \mathrm{c}$; per doz., $\mathbf{\$ 1 . 5 0 .}$

PAUL CRAMPBEL. Generally recognized as one of the best of all bright scarlet varieties. A splendid bedder, with enormous trusses of flowers freely produced on dwarf compact plants. Price each, $15 \mathrm{c}$; per doz., $\$ \mathbf{1 . 5 0}$.

RENE BOYSLEVRE. White at the center, shading to scarlet and violet at the edges of the petals.

Price each, $15 \mathrm{c}$; per doz., $\$ 1.50$.

SNOWDROP. A splendid bedding variety. Pure white. Very large trusses. A constant and abundant bloomer.

Price each, $15 \mathrm{c}$; per doz., $\$ 1.50$. 
EMILE ZOLA. A very fine French variety which marks a new departure in the color of Geraniums. The trusses are of phenomenal size composed of immense faultlessly formed wellrounded blooms. Growth shortjointed and dwarf. Color a superb tone of warm salmon with orange shadings.

Price each, $15 \mathrm{c}$; per doz., $\$ \mathbf{1 . 5 0}$.

\section{Double Geraniums}

BEAUTE POITEVINE. A beautiful type of semi-double Geranium. Exquisite salmon pink flowers. Very large.

Price each, 15c; per doz., \$1.50.

DE QUIRELLE. Violet purple slightly market white.

Price each, 15c; per doz., \$1.50.

E. H. TREGO. One of the most brilliantly colored Geraniums in existence. The color is an intense shade of orange scarlet, brilliant and effective. One of the best of the double varieties for bedding purposes.

Price each, 15c; per doz., $\$ 1.50$.

JEAN VIAUD. Rosy pink with white center.

Price each, 15c; per doz., \$1.50.

MAD. LANDRY. Clear salmon, center shading to copper, with white eye.

Price each, 15 c; per doz., $\$ 1.50$.

M. CONOVAS. superb dark crimson scarlet.

Price each, $15 \mathrm{c}$; per doz., $\$ \mathbf{1 . 5 0}$.

THOS. MEEHAN. Bright pink, upper petals stained orange.

Price each, 15c; per doz., $\$ \mathbf{1 . 5 0}$.

TRIOMPHE DE NANCY. Carmine red with white center. Price each, 15c; per doz., $\$ \mathbf{1 . 5 0 .}$

\section{Ivy Leaved Geraniums}

ACHIEVEMENT. A grand hybrid between the zonal and ivy section. It has the habit of the zonal, with ivy leaf and flower. For bedding it would be hard to equal,

Price each, 15c; per doz., $\$ 1.50$.

CARLOS UHDEN. A manificent variety, quite as the growth is extra dwarf. Color, brilliant rose pink, with a white eye. Price each, 15c; per doz., \$1.50.

COL. BADEN-POWELL. Pearly white with blush tints. A remarkable break in this class of Geraniums. Flowers of immense size. Price each, $15 c$; per doz., $\$ \mathbf{1 . 5 0 .}$

GRINGOIRE. A flower of superb size and splendid trusses. Color, bright rosy carmine.

Price each, $15 \mathrm{c}$; per doz., $\$ \mathbf{1 . 5 0 .}$

CHARLES MONSELET. Deep rosy red, upper petals nicely marked. Fine, large trusses on long, stiff stems. Free grower and very abundant bloomer.

Price each, 15c; per doz., $\$ \mathbf{1 . 5 0 .}$

CHARLES TURNER. The best known all Ivy Geraniums, and for all-around purposes one of the most useful. Deep, bright rosy pink in color, with very large flowers. When used as a bedder it produces a sheet of color. Price each, 15c; per doz., \$1.50.

ETINCELANT. One of the finest bright colored Ivy Geraniums ever raised. Color, intense orange scarlet. Flowers extra large. Price each, 15c; per doz., \$1.50.

FLAMBOYANT. A compact Ivy leaved variety. Superb orange scarlet in color. It is as bright in this respect as the well known variety La Pilot.

Price each, 15c: per doz., $\$ 1.50$.

INCOMPARABLE. A splendid shade of rosy carmine. Free blooming. Price each, $15 \mathrm{c}$; per doz., $\$ 1.50$.

HIS MAJESTY, THE KING. Soft rosy scarlet. Very double and of splendid form.

Price each, $15 \mathrm{c}$; per doz., $\$ 1.50$.

LEOPARD. A unique variety. Color, lavender pink, blotched crimson on the upper petals.

Price each, 15c; per doz., \$1.50.

LA FOUDRE. Brilliant orange scarlet. Extra large double blooms. $\quad$ Price each, $15 \mathrm{c}$; per doz., $\mathbf{\$ 1 . 5 0 .}$

MRS. H. J. JONES. Carmine rose feathered maroon on the upper petals. Price each, 15c; per doz., \$1.50.

PELADAN. Bright salmon pink, penciled maroon.

Price each, 15c; per doz., \$1.50.

SABRINA. Light scarlet, semi-double and a very free bloomer. $\quad$ Price each, 15c; per doz., \$1.50. 


\section{Pelargoniums}

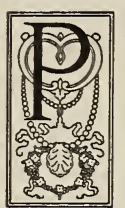

ELARGONIUMS, or "Lady Washington Geraniums," as they are commonly called, are among the most beautiful of our Summer and Fall flowering plants. They offer a rich and varied assortment of colors or combination of cclors, and the ease with which they may be grown should recommend them to everyone. There is a constantly growing demand for good Pelargoniums, and the collection we offer includes some of the finest varieties now in commerce. They are free blooming and large flowered. They make elegant specimens when well grown in pots, and if carefully pinched out, so as to make spherical plants, they rival Azaleas in beauty.

\section{Extra Choice Varieties}

ANNA RUDOLPH. Dark red with immense black blotches. A superb variety

ANDENKEN AN LONDON. Reddish scarlet, center white, upper petals blotched black.

ANDENKEN AN MOSCOW. Deep, rich purple, each of the petals marked with black blotches. A remarkable variety.

BALKONIGEN. An immense flowered light rose colored variety. Extra fine.

CARL HOLZMAN. Deep scarlet; upper petals handsomely blotched with black.

J. TOPFER. Compact growing variety. Flowers red with outer edges of petals white.

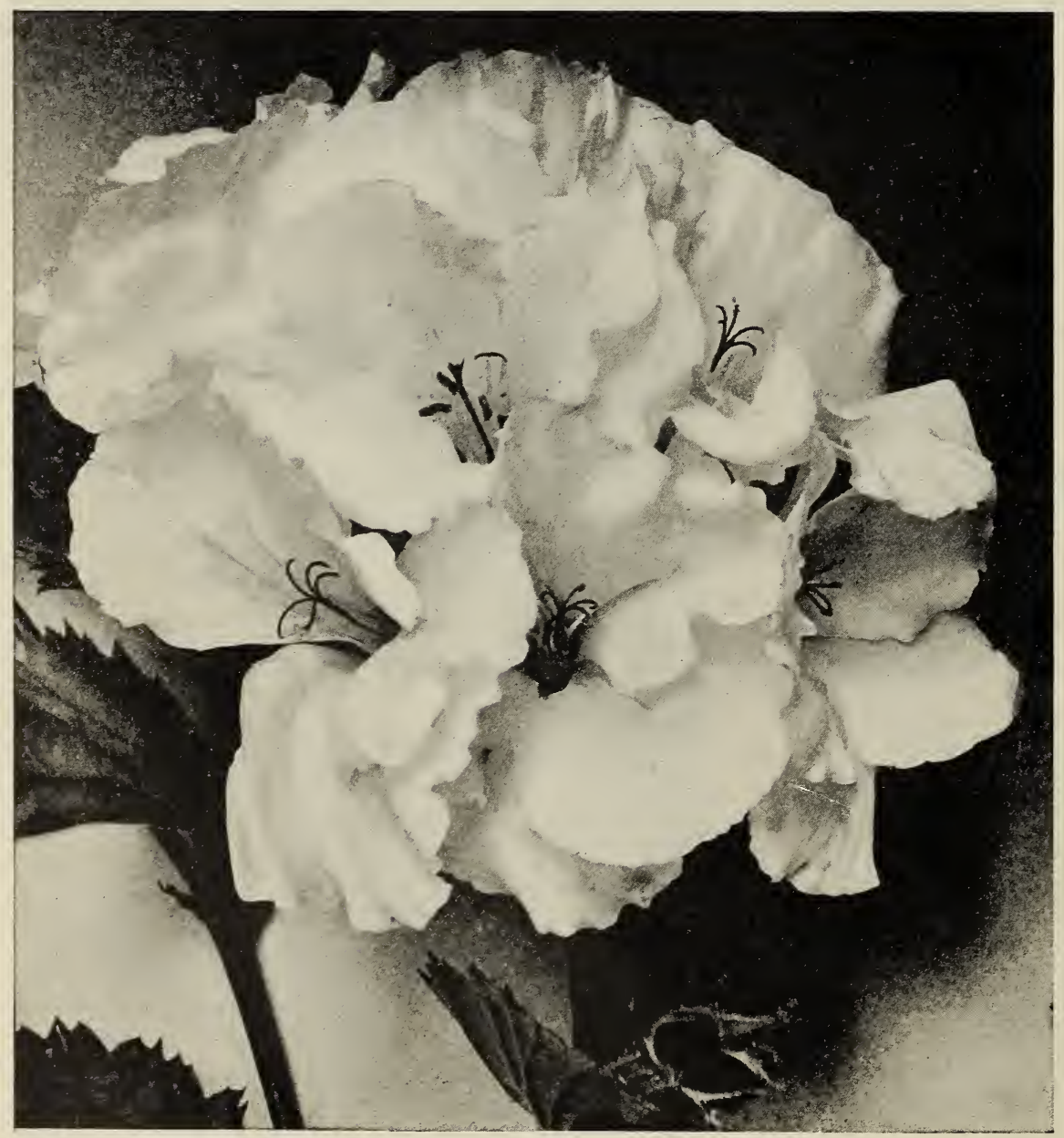

Pelargonium Olympe
ILLA. Salmon rose, handsomely blotched upper petals.

KATE BORNEMANN. White, daintily overlaid salmon pink; blotched rich crimson. A Superb sort.

MRS. KRUMB. Pale, soft rose, upper petals blotched deep purplish red.

MISS. SAUNDERS. Snowy white with two upper petals blotched rich purplish crimson. A striking sort.

MONTEBELLO. Delicate pink blotched with white.

OLYMPE. A remarkably free blooming giant white sort.

PROFESSOR CORRENS. Without doubt one of the largest flowered Pelargoniums grown. Blossoms of immense size, deep rose color, all of the upper petals being blotched black.

PETER HOSER. Fiery brick red with black blotches.

P A UL I N E SCHROETER. Deep rosy carmine with dark blotches.

YSENBERG. Light red with carmine rose. Edges of the white center, petals edged with white, dotted white over the entire surface of the flowers.

Price of any of the above superb sorts.

Price each, 25c; per doz., \$2.50.

\section{Older Standard Varieties}

ANITA. Center of flower white, margined bright rose. Upper petals feathered dark crimson. A gem.

BERTHA WAGNER. Deep carmine rose. Edged white.

BLUE MABEL. Dark carmine with velvety black blootches.

DUCHESS OF CORNWALL

Large flowered deep purple blossoms.

DUCHESS OF WESTMINSTER. Pink and white with crimson blotches.

MABEL. Upper petals maroon. lower ones bright rose.

MRS. E. H. CHILDS. A splendid variety with deep rosy pink flowers, the color being uniform throughout.

Price of above varieties, each $20 c$; per doz $\$ \mathbf{2 . 0 0}$. 


\section{Amaryllis}

(0)

UR MAGNIFICENT strain of Amaryllis is second to none in this country. Any attempt to describe them, even with the most glowing adjectives, would fail to convey an adequate idea of their surpassing beauty. They range in color from the pure white ground color with its markings of rose, red, etc., to rich orange, scarlet, cherry, bright red, crimson, maroon, mottled, striped, etc. The flowers are flat and spreading with full rounded and overlapping petals. The entire strain bears flowers of enormous size, the blooms averaging from nine to ten inches in diameter with five and six to the single stem. The stems attain a height of three feet, displaying the blooms to great advantage.

These Amaryllis are of easy culture and may be planted in the open border in warm sections of the country. In cold sections grow them in pots. Amaryllis are exceedingly easy to force and bloom within a few weeks after being potted up. These Amaryllis are the result of hybridization betrieen the finest types, extending over a period of several years. You cannot purchase better.

CLASS A. First size, selected flowering bulbs, which will bloom this Spring. Perfect in color, form, size and substance. Every one a gem.

Price each., 75c; per doz., \$7.50.

AMARYLLIS BELLADONNA. Lovely rose pink with lighter colored throat. As this variety loses its foliage before the flower spikes issue forth, care must be taken not to disturb the bulbs at this period. August is the time it flowers. Mammoth bulbs.

Price each, 35c; per doz., \$3.50.

AMARYLLIS FORMOSISSIMA. An original species, native of Mexico, with narrow reflexing and spreading petals. The color is an intensely rich deep crimson.

Price each, 35c; per doz., $\$ 3.50$.

\section{CULTURAL NOTE}

Plant the bulbs in any good garden soil which has had plenty of rotted manure added and thoroughly mixed together. Select the bed in any fully exposed sunny position. Plant them so that the top is even with the surface of the soil. When growth begins give water in sufficient quantities to keep the bed moist at all times. Irrigate-dont sprinkle. When the buds appear, a shading of cheese cloth will give highly perfected colors.

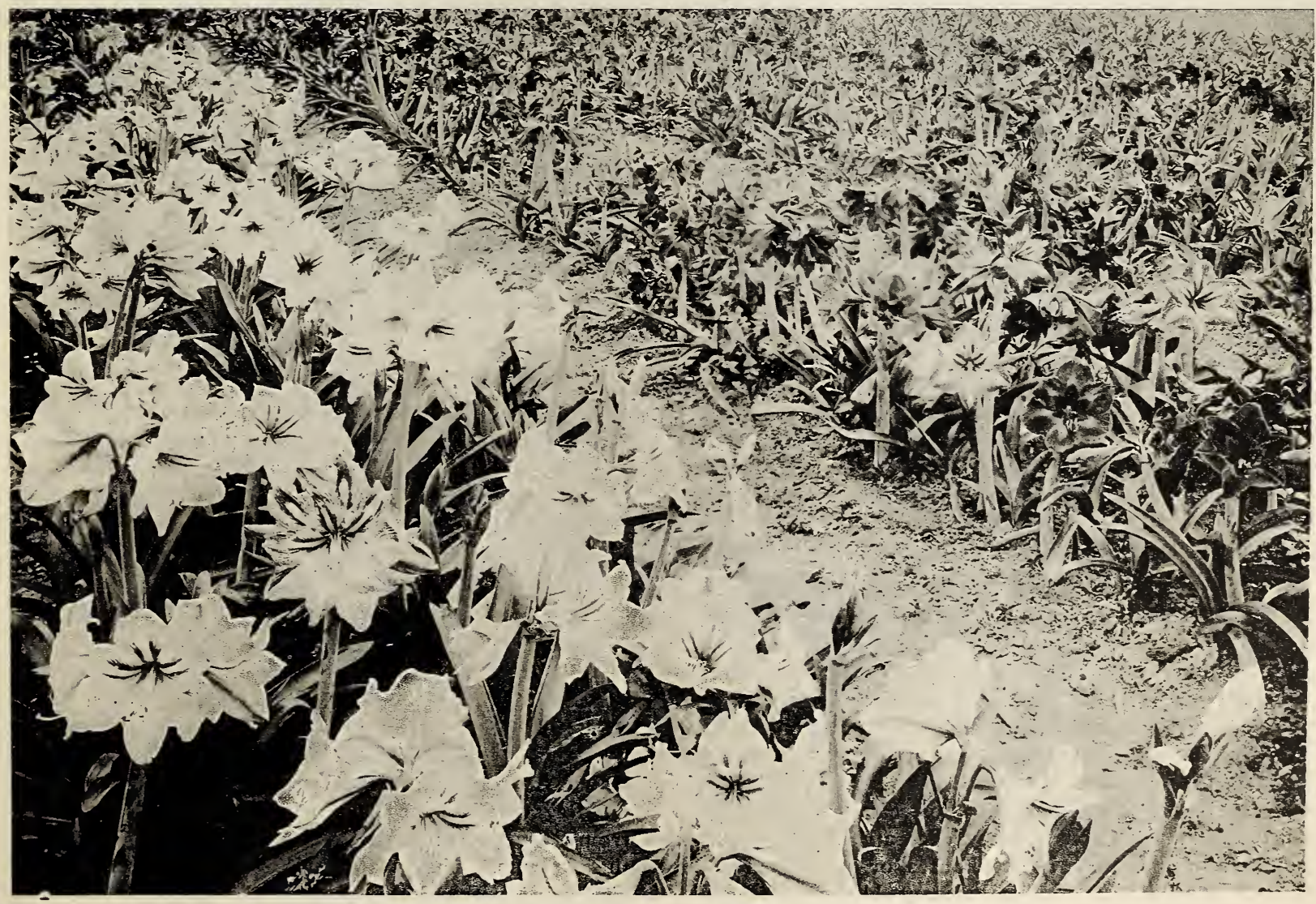

Field View of our Giant Flowered Amaryllis 


\section{BEGONIAS}

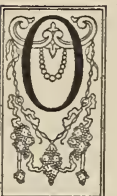

UR COLLECTION of these lovely Summer flowering bulbous plants is very fine indeed. The strain we offer is of the erect flowering class, flowers being borne quite upright on strong sturdy stems. The varieties offered are distinct and beautiful and those who try our strains will be well pleased with their magnificent size, perfect form, exquisite finish and colorings. Our culture of these plants during the past season occupied a lath area of some $2 \mathrm{r} / 2$ acres and included thousands upon thousands of plants in the various classes and strains. We had them in the double types, fully 6 inches in diameter, bearing a nearer resemblance to immense roses or double hollyhocks, than Begonias. These and the handsomely frilled types or plain edged singles were subject to unqualified admiration from the numerous visitors who saw them at the height of their glory. A general impression prevails in this section that Tuberous Begonias are more or less delicate in their nature, consequently hard to handle or grow. As a matter of fact, where proper conditions are accorded them, they may be grown with almost the same ease as a geranium and will give wonderful masses of color for a prolonged season. Attention to the cultural notes below will insure success.

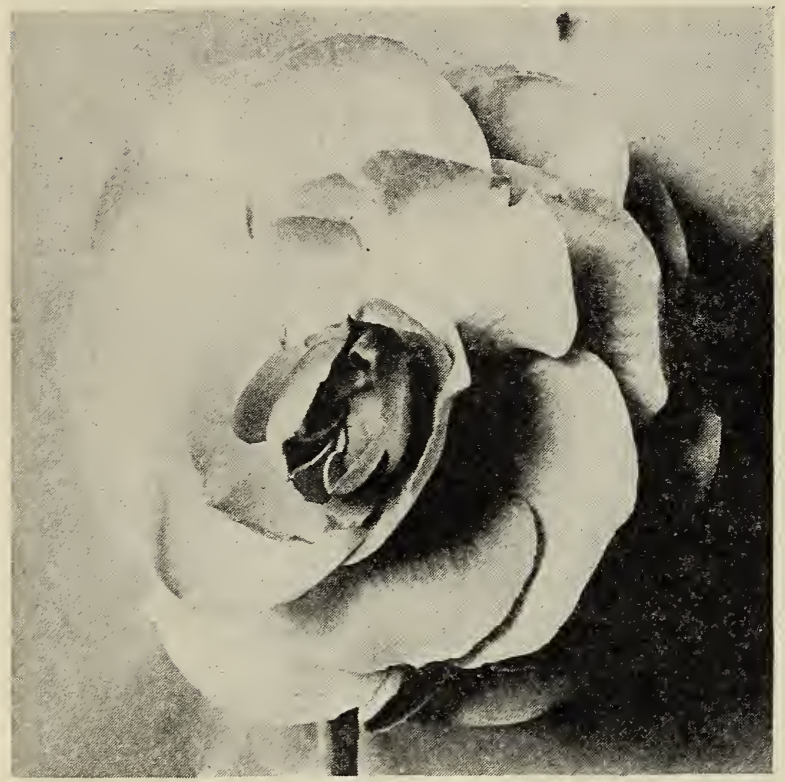

A Camellia Flowered Type of our Tuberous Begonia

\section{H \& S Prize Single Tuberous Begonias}

A very high-class strain with flowers of massive size, perfectly round in contour. Blossoms held quite erect on strong, stiff stems. They are wonderfully free flowering and contain a wide and diversified range of colors. Highly recommended for bedding purposes.

Price each, 25c; per doz., \$2.50.

\section{H \& S Prize Double Tuberous Begonias}

The bulbs we offer you are from a superb collection containing all colors from pure white through the soft colors of pink, rose, salmon, fiery scarlet crimson, orange and other intermediate shades. Blossoms of magnificent size and form. They vary in shape, some resembling a large full blown rose; others, a Camellia, all beautiful to a degree. Double Tuberous Begonias make excellent subjects for pot work, and when so treated are of great value for home or conservatory decoration. They may be grown in open beds, in lath houses, or in shady north borders, where they produce elegant blooming effects over a long period. $\quad$ Price each, 35c; per doz., \$3.50.

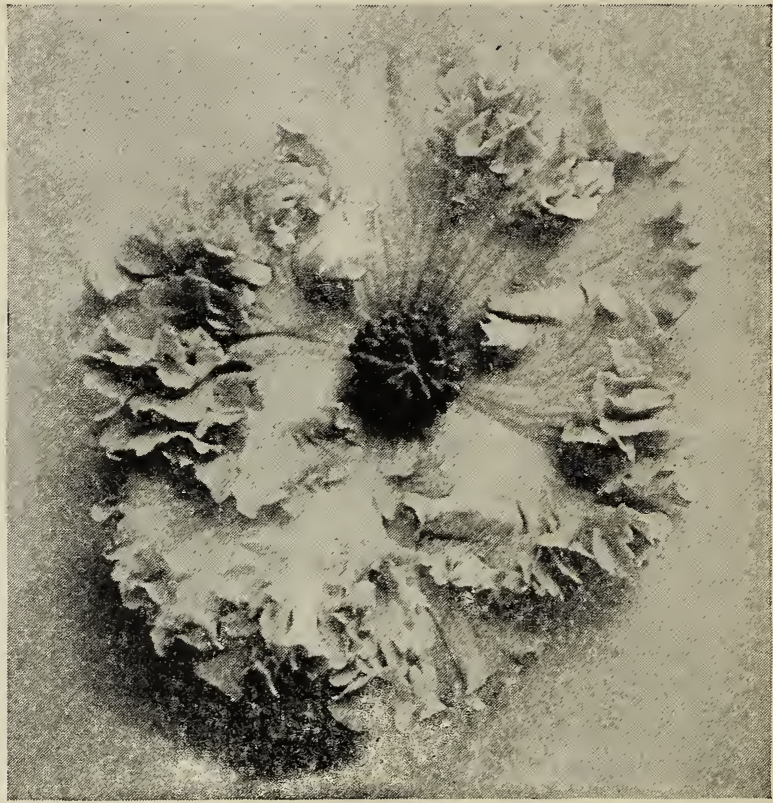

One of the Ruffled-edged Tuberous Begonias

\section{H \& S Prize Mixed Single Frilled Tuberous Begonias}

Among all the various strains to be noted in this elegant flowering tuberous plant, this class, to our mind, is one of the most beautiful of all. The edges are beautifully frilled, serrated and crested. The flowers have a lovely fringed appearance, graceful in the extreme. There is a daintiness about this class which will appeal to everyone. They form exquisite subjects when used as cut flowers in low table decorations. Try a few flowers of this class with an addition of some of their own foliage as a center-piece for your dining table and note the effect.

\section{IMPORTANT NOTICE}

Each season we grow a very large number of Tuberous Begonias in 3-inch pots, which are ready for delivery from May 1st on. We make no advance charge for these plants. They are the same price as dry tubers. Customers within local shipping distance will find it to their advantage to purchase these Begonias from pots, 
as it will save them the trouble of having to start them and insure an even growth in beds when they are planted out. These pot plants, however, are of no value to those who live at great distance, and the only way they can receive the bulbs would be in dormant condition. We can supply these latter up to May 1st.

\section{CULTURAL NOTE}

If there is any plant grown which is of easy culture it is certainly the Tuberous Begonia, and yet there are few others in which as many failures occur as in the growing of these beautiful subjects.

To begin with, the same conditions accorded ferns suits them admirably. They require a very rich soil with plenty of moisture, but, above all, a well-spaded position where the bed has been raised to insure drainage.

As soon as tubers are received in the Spring, plant them in shallow boxes or flats, using a rather light mixture of sand, leaf mould or peat, mellow loam and well-rotted cow manure, in the proportion of one-quarter sand one-quarter peat, one-quarter cow manure, and one-quarter loam. Mix well and place in the boxes to a depth of 4 inches; level off and firm well. With this complete, insert the tubers about 4 inches apart each way, covering the crown with one-half an inch of the same mixture.

Place the boxes in a warm, shady green-house or lathhouse, keeping the boxes moderately moist at all times. They soon start to grow, and when they attain a height of 3 to 4 inches, they may be cut in squares with a sharp knife and transplanted to a shady bed on the north side of a building, a north wall, or under a well-vined pergola; planting a distance of 15 inches apart each way.

\section{Agapanthus}

UMBELLATUS. Among the various Summer flowering bulbs there are but few which grow as easily or are more effective in the garden insofar as their bloom is concerned, than well grown clumps of Agapanthus. The variety in question produces a continual succession of strong flower stems, each crowned with large umbels of deep blue flowers. Fine, strong clumps.

Price each, 35c; per doz., \$3.50.

WHITE. A splendid pure white form of the ordinary umbellatus and equally valuable as a decorative bulbous plant in the garden.

Price each, 35c; per doz., $\$ \mathbf{3 . 5 0}$.

\section{Calla Lillv}

RICHARDIA AETHIOPICA. The well-known Lily of the Nile. Strong, fine roots.

Price each, 20c; per doz., \$2.00.

RICHARDIA ELLIOTTIANA. The Golden Calla.
Flowers deep golden yellow. Foliage beautifully maculated with white on a green ground. Splendid for Summer blooming. 5-inch pots, Price each, 35c; per doz., \$3.50. Price each, $75 \mathrm{c}$; per doz., $\$ \mathbf{7 . 5 0}$.

THE GODFREY. A lovely miniature flowered form of the large Calla Lily. The plants attain a height of about 18 inches to 2 feet. The blossoms are only about onethird the size of the large flowered form. Splendid for growing in pots or for low borders in the garden. This lovely miniature flowered form is not commonly known, but it is deserving of increased cultivation.

Price each, 25c; per doz., $\$ \mathbf{2 . 5 0}$.

\section{Cyclamen}

We grow a large stock in a very choice strain of these well-known Winter flowering plants and can supply them in all colors, from pure white to crimson, including shades of salmon, pink, etc. Aside from the value of Cyclamen as a pot grown decorative plant, they are of great value when treated as bedding plants in rockeries, ferneries, or planted in masses under the shade of trees. This use, however, is confined only to sections where heavy freezing conditions do not prevail. In Southern California they do splendidly in the open ground and bear great masses of blossom season are season.

The curirs should be planted so that the crown is even with the surface of the ground; deep planting induces damping off. Extra fine plants from 3-inch pots.

Price each, 35c; per doz., $\$ \mathbf{3 . 5 0}$. 


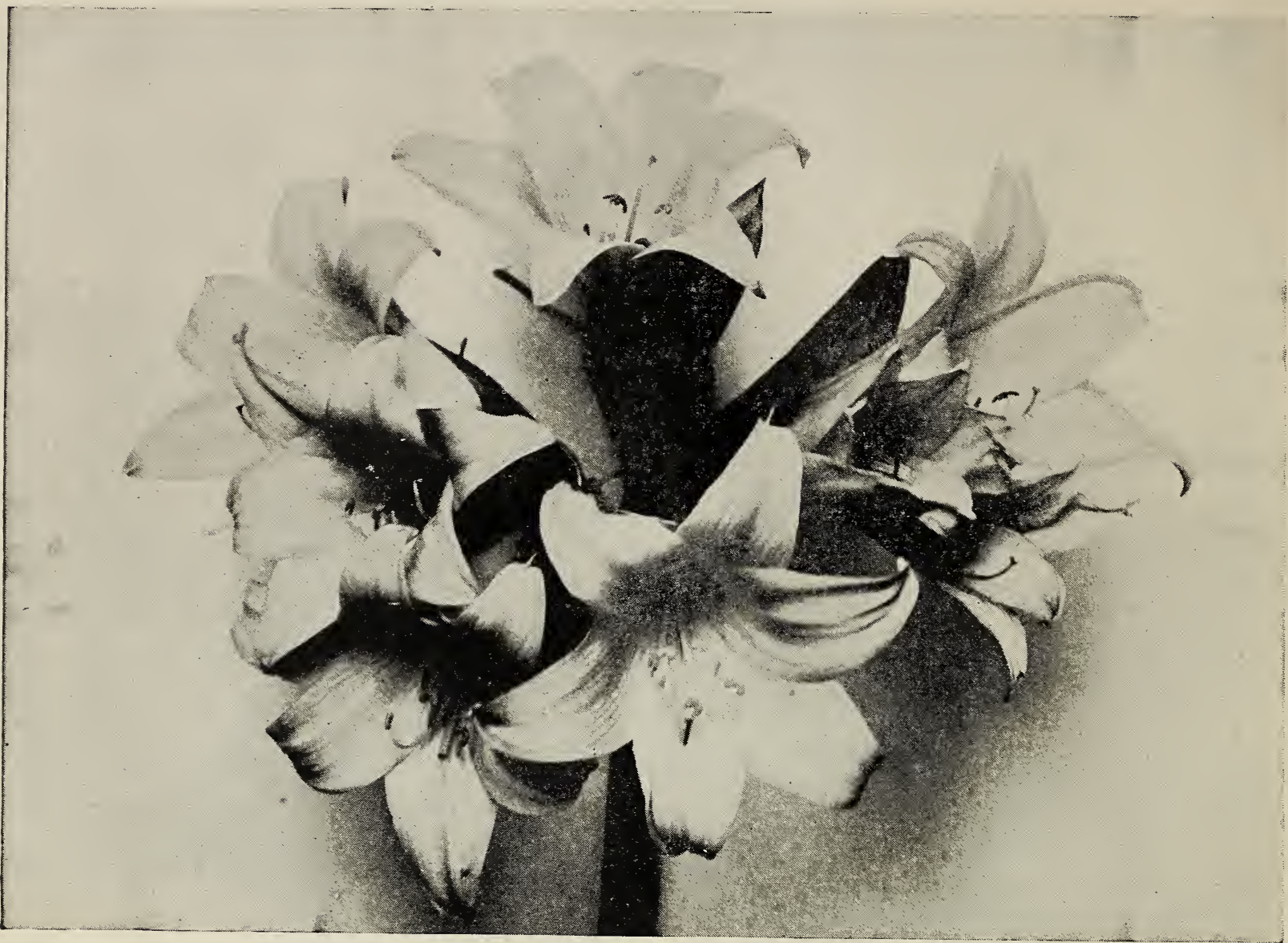

\section{Amarcrinum Howardii}

Among the various novelties resulting from our work in the cross-breeding of plants, we consider this as being easily the most remarkable of our productions. It is a true bi-generic hybrid, of which there are but comparatively few in existence. It is a true cross of Crinum-Moorei on Amaryllis Belladonna, the latter being the seed bearing parent. The value of this new plant lies in its usefulness as a bulbous plant for growing in pots or for planting in the open garden. Its beautiful soft pink color, the immense trusses of bloom which it bears, combined with the lasting character of its flowers, place it in a class by itself. Stems four feet long, with immense heads of bloom, suitable for vases, etc., are freely produced throughout the Summer and Autumn months. The tone of soft pink to be noted in its flowers is one that is rarely seen and will appeal to everyone.

Plants in full bloom of this remarkable hybrid were exhibited in London before the Royal Horticultural Society in September of last year, where it was unanimously awarded a first-class certificate. Later on it was awarded the major prize, the Cory Cup, as the most important novelty certificated during the entire year. We believe this is the only time in history that the highly prized Cory Cup has been won by an American firm. We can only add that it is a plant of superb beauty and worth and of easy cultivation. In climates such as Southern California, it can be grown to perfection in the open ground, requiring much the same attention as Amaryllis Belladonna or the various Crinums. In sections where much cold weather prevails, it can be flowered beautifully in tubs or pots. We have only a limited stock to offer this season. 


\section{Gladiolus}

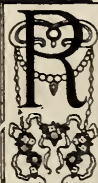

EMARKABLE improvements in Gladiolus have been made in recent years and numerous fine strains or varieties are now obtainable. They are today among the most popular of all our Summer and Autumn blooming bulbous plants. You will find the named varieties which we offer you below of sterling worth and our special mixture as good as can be procured. Gladiolus are of the simplest culture possible. They delight in a light rich soil. The bulbs should be planted some three inches below the surface and a space allowed between them of some 6 to 8 inches. They require copious supplies of water during their growing period. By planting them at different times, a constant succession of handsome spikes may be had over a long period. Their adaptability as cut flowers and the glorious range of colors and combinations of colors which they present has given them widespread popularity.

AMERICA. Color, an exquisite shade of lavender pink. Blossoms very large, carrying 8 to 10 well-expanded flowers on a spike at one time.

Price each, 10c; per doz., 75c.

GRETCHEN ZANG. We feel sure that those who are not already familiar with this new variety will be delighted with it. The color is a pleasing shade of silvery rose with pencilings of rich scarlet, merging to crimson at the base of the throat. This delightful color combination makes this variety distinct from all others.

Price each, $15 c$; per doz., $\$ 1.50$.

HALLEY. Beautiful salmon pink. Individual flowers very large and well formed. The plant is a sturdy grower, a very popular market variety.

Price each, 10c; per doz., 75c; per 100, $\$ 6.00$.

LENA GRATZ. A splendid new Gladiolus, almost pure white in color. Flowers beautifully disposed on the spike. A grand cut flower variety.

Price each, 15c; per doz., $\$ 1.50$.

MRS. FRANK PENDLETON. One of the best recent introductions in Gladiolus. Blossoms of enormous size. The ground color is rosy pink, shading lighter at the edges. Throat beautifully blotched with deep crimson and maroon, with pencilings of scarlet reaching towards the edges of the petals. Plants vigorous; stems strong and wiry. A very fine cut flower variety.

Price each, 10c; per doz., \$1.00; per 100, \$7.50.

MRS. DR. NORTON. A lovely combination of pink and cream; one of the most sensational varieties of recent introduction. A variety in a class by itself and should be largely grown. Price each, 10c; per doz., \$1.00.

MYRTLE. A recent introduction in Gladiolus and, according to our estimation, one of the finest. The flowers are a light salmon in color and are well placed on the stalk. This variety is particularly notable for the lasting quality of its flowers, as many as 7 or 8 blossoms being open on a stalk at one time.

Price each, 15c; per doz., \$1.50.

MRS. FRANCIS KING. A fine, light scarlet Gladiolus of immense size and substance. The blooms open out flat with a large number open on the spike at tine same time. As fine a thing in scarlet as America is in pink. Fine bulbs.

Price each, 10c; per doz., \$1.00.

PRINCE OF WALES. A very early flowering Gladiolus with flowers of superb size, flowers well placed on the stems. Color is a delicate shade of apricot pink, overlaid with salmon. A grand variety for cutting purposes.

Price each, 15c; per doz., $\$ 1.50$.

PRIMULINUS HYBRID GLADIOLUS. A compara- tively new class of Gladiolus obtained by crossing the original African species primulinus with those of the older varieties. These Gladiolus are usually of smaller size than those of the Gandavensis or Lemoinei types. The flowers are orchid-like in nature and are beautifully placed on strong wiry stems. The range of colors is quite distinct from those in the larger flowered types, rich in shades of golden bronze, apricot shell pink, brilliant orange, etc. Strong flowering bulbs.

Price each., 10c; per doz., $\$ 1.00$; per $100, \$ 8.00$.

SCHWABEN. Color, pale lemon yellow, with a dash of red at the base of the throat. An excellent variety for cutting. Large, full flowers, closely set on spike. The best light yellow.

Price each, 10c; per doz., \$1.00; per 100, $\$ 7.50$.

SUNRISE. A very richly-colored flower with large, full, well-open blooms. Bright red in color, daintily blotched in the throat. A variety of truly regal beauty. Price each, 15c; per doz., \$1.50.

VIRGINIA. A splendid, new variety, in color a rich glowing crimson scarlet. A magnificent variety in every sense of the word. Large, full open flowers, intensely brilliant. A grand variety either for garden decoration or for cutting purposes. Price each, $15 \mathrm{c}$; per doz., $\$ \mathbf{1 . 5 0}$.

HOWARD \& SMITH MIXED HYBRIDS. Under this head we offer you a strain of mixed hybrids of superior quality. Contained in the mixture this season are many new colors with flowers of mammoth size. They comprise not only the best named varieties, but a number of seedlings of our owr production, which are exceptionally fine. We doubt if a better mixture can be procured anywhere. Extra selected bulbs in a superb mixture of colors. Price each, 10c; per doz., 75c.

\section{Gloxinias}

Our cultures of this regal bulbous plant are very extensive. Our strains comprise not only the netted and spotted types, but the pure selfs in all colors, from pure white to darkest crimson, rich purple, mauve, pink, rose and others. All of the true crassifolia type, a class with broad reflexed foliage and a dwarf habit. The blossoms are held perfectly erect. They make superb subjects for interior decoration or greenhouse culture. Gloxinias may be had in flower almost any time of the year, depending upon the period when the bulbs are potted up. From plantings made in August, a grand display of bloom may be had at Christmas.

Price each, 25c; per doz., $\$ 2.50$. 


\section{Iris}

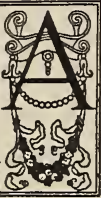

MONG the various hardy plants cultivated in gardens, there are but few, if any, which can exceed the beauty of the various types of Iris. Their popularity is due not only to the beauty and variety of their colors, but the ease with which they may be grown. During recent years hybridists have devoted considerable attention to the improvement of this race of plants and their efforts have been fraught with much success. The greatest improvement in any particular class has been in the bearded forms, hybrids of pallida, plicata and others. They are the giants of the family, both as regards height of the plant and size of their flowers. In the set which we are offering you below are some of the most magnificent acquisitions obtained up to the present time. Varieties like Magnifica, Ambassador, Ballerine and others need only to be seen to be appreciated. The colors are superb, the varieties are distinct, their usefulness for cutting purposes or for garden ornamentation is of unquestioned value.

\section{Twelve Magnificent Novelties}

AMBIGU. Standards of distinct reddish purple color. Falls maroon reticulated with brown at the base. Beard. orange-yellow. Height, 2 feet.

Price each, $\$ \mathbf{1 . 0 0}$.

AMBASSADOR. Easily one of the finest introductions in Iris during modern times. The stout stem bears flowers of magnificent size and form and quite unique as to color. Standards are deep lavender shot with bronze. Falls maroon with purplish cast. Price each, \$1.50.

BALLERINE. A superb novelty in every sense of the term. This lovely Iris reaches the height of 4 feet, the broad foliage being surmounted with masses of glorious orchid-like flowers. Standards are a wonderful shade of porcelain blue, broad and rounded with wavy margins. Falls of a slightly deeper shade of blue. A deliciously scented variety.

Price each, $\$ 1.50$.

BOSNIAMAC. Standards primrose yellow, falls primrose shot with blue, with the base of the falls reticulated with blue. A very fine sort, one of the best in its class of shades approaching yellow. Price each, $\$ \mathbf{1 . 0 0}$.

CLUNY. A lovely Iris. Standards are wistaria blue, falls soft bluish violet with darker shadings. Very free. Larger and finer than Caterina in every way. Height, 4 feet.

Price each, $\$ 1.00$.

DEJAZET. Standards lavender overlaid with brown, falls purple with sepia brown. Height, 2 feet.

Price each, $\$ \mathbf{1 . 0 0}$.

GREVIN. Standards violet with bronze shadings, falls velvety wine red, reticulated at the base with golden brown. Height, 2 feet.

Price each, $\$ \mathbf{1 . 0 0}$.

MAGNIFICA. This Iris has been well named and is all the name implies. The flowers are simply enormous as to size, borne on stiff branching stems, which attain a height of 4 feet. The falls are a superb shade of dark reddish violet, the standards light violet blue. An exquisite variety in every sense of the term.

Price each, $\$ 1.00$.

ME.DRANO. A remarkable Iris in every way. Flowers of large size with standards of reddish copper color. Falls reddish purple overlaid with blue, flaked with lavender and buff. Height, 2 feet.

Price each, $\$ 1.00$.

MOLIERE. Standards light blue overlaid with brown, falls purplish maroon merging lighter at the outer edges of the petals. Blossoms of enormous size, a variety of exquisite form and substance.

Price each, 75c.

OPERA. A very distinct variety with flowers of fine shape. Standards are coppery brown shot with purple.
Falls wine red, base of the petals bronzy maroon penciled with gold. Height, 2 feet.

Price each, $\$ \mathbf{1 . 0 0}$.

RAFFET. Standards an intense violet blue, falls dark violet reticulated with white and violet in the upper portion of the petals. Height, 2 feet. Price each, 75c.

\section{Special Offer}

One each of the above Iris, a set of unequaled quality, for $\$ 10.75$.

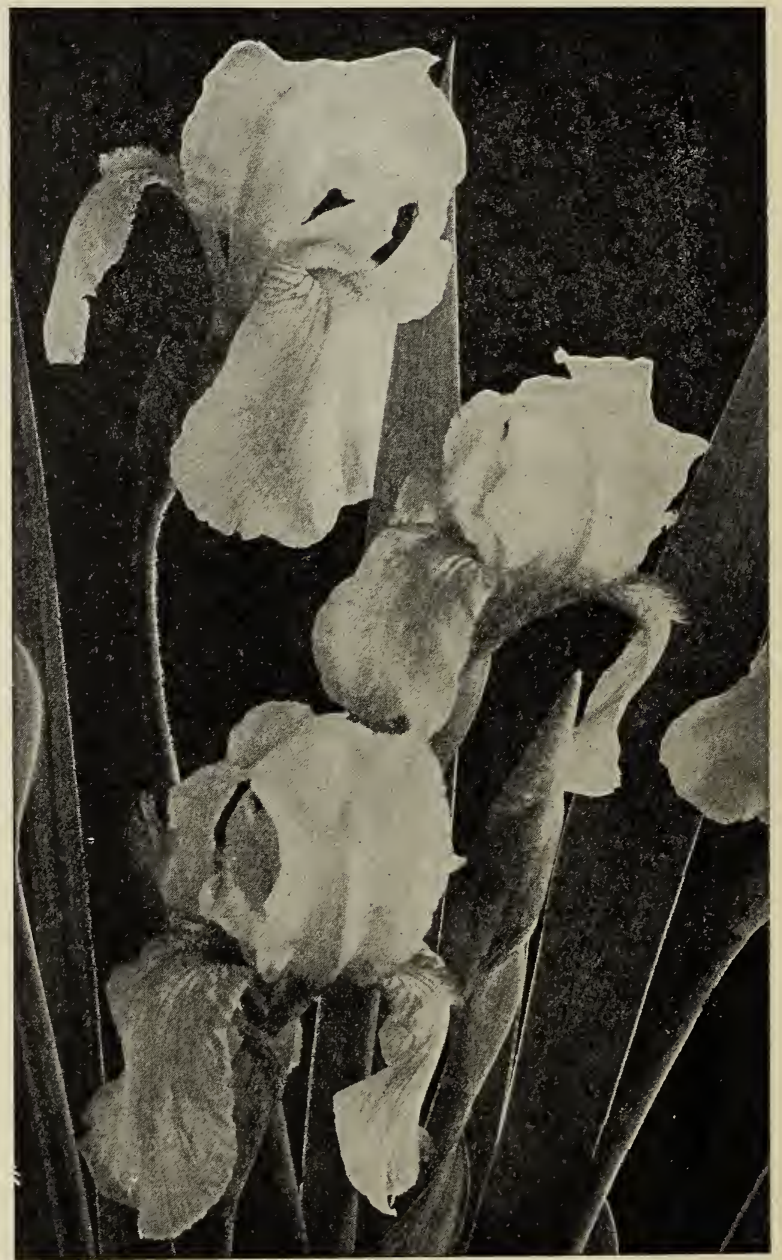




\section{Recent Introductions}

Under this heading we offer you a choice collection of more or less recent introduction in this lovely class of plants. They are mostly of French origin and mark one of the greatest advances ever made in the improvement of this favorite plant. The varieties included in this collection are of the same race of hybrids as those to be noted above.

They have the same sturdy growth, the immense size blossoms, with a range of colors which is at once striking and beautiful. The varieties have been carefuly selected from a large number now under trial and we feel quite certain they will be a source of delight and pleasure to those who plant them.

ALCAZAR. Blossoms of enormous size. Easily one of the handsomest bearded Iris in the collection. A strong, vigorous grower, with much branched stems. It bears flowers of gigantic size, displaying to great advantage a wonderful combination of colors. Standards are bright deep blue. Falls violet purple with a prominent yellow beard. Height, 3 feet.

Price each, 35c.

AMAS. Immense globular flowers. Standards a lovely shade of lavender blue. Height, 2 feet. Price each, 35e.

ARCHEVEQUE. Standards a rich shade of reddish purple. Falls dark velvety purple. This variety might well be regarded as an ever-blooming variety. It bears quantities of flowers, not only during the Spring, but during Fall until Winter. Height, 2 feet. Price each, 35c.

CHERUBIN. An exquisitely colored variety. The standards a distinct shade of pale lilac. Falls lavender veined with white. Height, $2 \mathrm{~L} / 2$ feet. Price each, 25c.

CAPRICE. Enormous flowers in a lovely shade of pure violet blue. Very attractive as a cut flower, its size being remarkable for its class. Height, $2 \frac{1}{2}$ feet.

Price each, 35c.

CANDELABRE. A distinct shade of pale blue veined and marked with purple. Stems very much branched, bearing large numbers of handsome flowers. Height, $2 \mathrm{~T} / 2$ feet.

Price each, 35c.

CATERINA. A superb variety. Unquestionably one of the handsomest of all Iris. It is a giant, not only in height, but also in the mammoth size of its blossoms. The stems are long and much branched, bearing flowers of a clean, even shade of lavender blue. An exquisite variety any way you take it. Height, 4 feet.

Price each, 25c.

ED. MICHEL. In our opinion one of the finest Iris introduced in modern times. The flowers are of immense size, beautifully poised on tall, vigorous growing stems. The standards are broad and frilled, of a distinct shade of reddish violet. The falls slightly deeper in color than the standards. Height, 3 feet.

Price each, 50c.

ELDORADO. Standards yellowish bronze, exquisitely shaded with heliotrope. Falls bronze overlaid with blue. Height, 3 feet.

Price each, 35c.

FAIRY. One of the daintiest of all tall flowered Iris. Blossoms of moderate size. Standards and falls prettily suffused with lavender. Has a conspicuous orange beard, Height, 3 feet.

Price each, 25c.
GOLDEN FLEECE. A comparatively dwarf intermediate type of Iris, bearing handsome light yellow flowers equivalent in color both in standards and falls. A dainty variety when used in the foreground of taller growing sorts. Height, $11 / 2$ feet.

Price each, 35c.

ISOLENE. One of the progenitors of this giant race of hybrid Iris and still one of the best. The plants are of tall growth. The standards brownish lavender shot with bronze. Falls light purple overlaid with bronze, striped with golden brown at the base. Beard a distinct golden yellow. Height, 3 feet.

Price each, 35c.

JEANNE d'ARC. One of the daintiest Iris in existence. Ground color, pure white, both in standards and falls, with pencilings of light blue at the outer edges of the petals. This variety is a remarkably free bloomer and equal to the finest orchid in point of beauty. Height, $2 \mathrm{t} / 2$ feet.

Price each, 35c.

KING OF IRIS. Massive, well-built flowers of splendid texture. Standards rich old gold. Falls broad, in color rich velvety maroon shot with old gold. A striking combination of colors. Height, 2 feet.

Price each, 35c.

KHARPUT. Standards deep purplish blue. Falls violet blue. Colors are intense in both standards and falls. A very choice variety, well worth consideration. Height, 30 inches.

Price each, 35c

LOUTE. Standards deep lavender shot with brown Falls purplish wine color, striped with brown at the base of the petals. Beard orange yellow. Blossoms of enormous size. Height, 2 feet.

Price each, 35c.

LA NIEGE. A dainty creamy white semi-tall variety Very free in bloom, pure in tone. Very desirable. Height, 2 feet.

Price each, 35c

MRS. REUTHE. A very early flowering variety with moderate-sized flowers. Standards and falls a delicate lavender blue. Although not large in size of bloom. it is a variety of exquisite beauty. Height, 2 feet.

Price each, 35c.

MONSIGNOR. Richly colored and remarkably free Standards pale violet purple, falls overlaid and reticulated with deep purple. Flowers of immense size and splendid substance. Height, 30 inches. Price each, 35c.

NEUEE d'ORAGE: Standards a peculiar shade of grayish lavender. Falls light lavender overlaid with bronze. A variety of remarkable effects and as beautiful as it is remarkable. Height, 30 inches. Price each, 35c.

ORIFLAMME. Flowers of gigantic size on stout branching stems. Standards a lovely shade of rich bright blue. Falls deep purple. A fine variety. Height, $2 \mathrm{~T} / 2$ feet.

Price each, 35c.

PROSPER LAUGIER. Standards bronze with a suffusion of heliotrope blue. Falls rich velvety maroon with brown pencilings at the base of the petals. Beard golden yellow. Very free, a veritable mass of color during the months of April and May. Height, 3 feet.

Price each, 35c.

PARISIANA. Standards light lavender shot with white. Falls blotched with white, reticulated at the edges of the petals with lavender. A handsome flower. Height, 30 inches.
Price each, 35c. 
PRINCESS VICTORIA LOUISE. Medium as to height, but very free in bloom and even as to growth. Standards pale sulphury yellow. Falls rich plum color, margined with cream at the edges. Height, 20 inches.

Price each, 25c.

SHERWIN WRIGHT. Bright golden yellow in both standards and falls. Dwarf as to height, attaining in its maximum growth 20 inches. Although only a flower of moderate size, we believe it to be the brightest golden yellow Iris in commerce today.

Price' each, 35c.

WALHALLA. Standards lavender, falls wine red. Flowers of medium size, very free; an exquisite sort for the low front border. Very attractive in massed effect. Height, 2 feet.

Price each, 35c.

ZEPHYR. One of the daintiest Iris in our entire collection. The flowers are of medium size only, but are exquisite in their color value, the latter being a lovely shade of clear lavender blue. The plants are literally covered with flowers during the months of March and April. Height, 3 feet.

Price each, 35c.

\section{Special Offer}

One each of the above 29 superb varicties of Iris, a collection which spells the last word in quality or excellence, for

$\$ 8.00$.

Any 12 of the above varieties, for

$\$ 3.50$.

\section{CULTURAL NOTE}

All of the Irises noted in the foregoing section belong to what is known as the rhizamatos group and are among the easiest to cultivate. They are amenable to culture in all kinds of soil. They do well in full sun or partial shade. The plants should be set at a distance of about 18 inches apart each way for best results. The rhizome, or the creeping root stock of these Iris, should not be buried too deeply. A covering of about two inches of soil over it will be sufficient. They will grow to perfection in any good friable garden soil and require but little attention other than watering and an occasional top dressing of well-rotted manure, which should be given just prior to the time that the Spring growth begins. Unlike the Iris of the Japanese type, these will not stand excessive conditions of moisture. The soil should be well drained, or there will be a tendency for the rhizomes to rot.

\section{Japanese Iris}

The latest introduction from Japan in this magnificent class of Iris are marvels of beauty. The flowers often reach a diameter of 10 inches and colors and combinations of delicate shades in both single and double forms simply baffle description. Although they are among the easiest of all Iris to bring to a state of perfection, both as regards quality of bloom, height of growth, etc., we doubt if more failures occur in growing any plants than these. This is simply due to lack of understanding regarding their requirements. They require an abundance of moisture during their growing season and plenty of well-sorted manure.

Large clumps. Price each, 50c; per doz., $\$ \mathbf{5 . 0 0}$.

\section{Iris}

ORIENTALIS. A lovely form of Siberian Iris with long, grassy foliage and tall, slender stems; fine for cutting. Color deep blue. Price each, 25c; per doz., \$2.50.

STYLOSA. The blue and white forms of this lovely species begin to bloom early in October and continue through the winter season, coming into bloom at a' season when flowers are scarce, making them particularly valuable, and adds a touch of color to the garden. They require partial shade for the best results. Strong divisions.

Price each, 25c; per doz., \$2.50.

\section{Ismene}

CALATHINA GRANDIFLORA. A beautiful free blooming bulbous plant from Brazil and one which is especially adaptable to culture in warm Southern climates. The large blooms are intensely fragrant, pure white in color, with greenish bands in the base of the throat. The edges of the petals have a fringed outline, which greatly enhances the beauty of the blooms. Very unique and highly desirable for the conservatory or house plant; does well in protected spots in the open ground. Strong bulbs. Price each, 35c; per doz., \$3.50.

\section{Montbretias}

A particularly useful and beautiful class of Summer flowering bulbous plants. Erect star-like flowers are produced on long, wiry stems. They are exquisite subjects for use as cut flowers or for the color effect which the clumps in bloom produce as a matter of garden ornamentation.

HEREWARD. Blossoms a wonderful shade of deep orange, zoned and stained with crimson at the base of the petals.

FIRE KING. Rich glowing vermilion scarlet-a lovely shade.

GOLDEN WEST. A clear, bright golden yellow.

LADY HAMILTON. Extra large flowers. Yellow shading to deep apricot.

Price of any of the above varieties, strong, dormant bulbs. Price each, 15 ; per doz., $\$ 1.50$; per $100, \$ 10.00$.

\section{Lycoris Squamigera}

A little known bulbous plant, similar in form and color to the Amaryllis Belladonna, but differing from it in its time of bloom. It sends forth in August strong spikes of bloom of a beautiful pink shade. Strong bulbs. Price each, 35c; per doz., \$3.50.

\section{Tuberoses}

SINGLE. An exquisite single form of tuberose with dainty star-shaped flowers, borne on long, sturdy spikes, white in color, intensely fragrant. A very attractive flower, worthy of a place in any garden. Exceedingly graceful as a cut bloom.

Price each, 15c; per doz., \$1.50; per $100, \$ 10.00$.

\section{Sparaxis}

PULCHERRIMA. A lovely species of Sparaxis from the Cape of Good Hope. Height about 6 feet. The dainty bell-shaped rose-colored flowers hang on slender filament-like stems and their weight causes the long stems of the flower shoot to arch gracefully. A very rare and beautiful plant. Price each, 50c; per doz., \$5.00.

\section{Sternbergia Lutea}

A lovely bulbous plant bearing erect crocus-like golden yellow flowers during the months of August and September. Blossoms are produced on long, slender stems in great profusion. A bed in bloom presents a veritable carpet of bright golden yellow.

Price each, 20c; per doz., \$2.00. 


\section{Herbaceous and Perennial Flowering Plants}

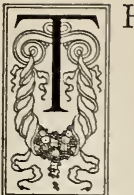

HE VALUE of Perennials, both hardy and tender for planting in borders, beds, etc., is well recognized. There is no more valuable or attractive adjunct to a well-ordered garden than Herbaceous borders. These, when properly arranged, give a continued and unbroken display of blossom and foliage throughout the entire year. In California, during recent times, the trend of planting not only on large estates, but in smaller gardens, has been purely to shrubbery groups, with little or no color to relieve the monotony of the general landscape. Plantings have been so strongly followed along these lines that the general results to be noted around many homes and public places, is that of planting which would be more appropriate for a cemetery than a home. Flowers serve to accentuate the beauty of a garden, and without them it can truly be regarded as incomplete. There are but few plants more popular today than the section usually classed under this heading. The ease with which they may be grown and the endless variety of subjects which may be utilized should recommend them to everyone. Plants which we offer have been grown in the rich silty soil of our Rivera nurseries. They are sturdy stock and such as will give you maximum results.

\section{Acanthus}

MOLLIS. A handsome flowering plant for herbaceous borders, with large spikes of bright rose-colored flowers. Leaves broad, dark glossy green in color, handsomely notched on the edges. Height, 4 feet.

Price each, 35c; per doz., \$3.50.

\section{Ageratum}

BLUE GEM. A dainty dwarf blue Ageratum which attains a height of 4 to 6 inches. Flowers are delicate sky blue and so freely produced as to entirely hide the foliage. One of the daintiest of all subjects for edgings or it may be used in mass plantings by itself. An ideal plant for Summer bedding. Strong plants from 2-inch pots.

Price each, 10c; per doz., \$1.00.

\section{Aquilegia-Columbine New Long Spurred Hybrids}

The value of Columbines for bedding purposes, their beauty for use as cut flowers and their hardiness and ease of growth, recommend them as one of the most useful of all herbaceous perennial plants. We have been selecting and re-selecting flowers of the long spurred type for many years until at the present time we believe the strain of either seeds or plants that we are enabled to offer our customers is equal or superior to any other obtainable anywhere today. The mixed strain contains all shades from pure white to deep purple, including yellow, rose, red, pink, mauve, with many handsomely bi-colored flowers. These are offered under the sections to be noted below. All we can say in conclusion is that we are certain that it is a strain of such quality that it will please the most exacting of our customers.

BLUE SHADES. A splendid selection, coming almost entirely true to type, containing all shades of blue, lavender, mauve, purple, etc. Blossoms of the true, long spurred type, immense as to size. An exceedingly fine selection. Extra strong field grown clumps.

Price each, $35 \mathrm{c}$; per doz., $\$ \mathbf{3 . 5 0}$. 2-inch pot plants. $\quad$ Price each, $15 \mathrm{c}$; per doz., \$1.50.

PINK SHADES. A grand selection in variable shades of pink, rose, apple blossoms, shell pink, dark rose, etc. The dainty colors to be noted in this particular selection will appeal to everyone where they are desired for use as cut flowers. Extra strong field grown clumps.

Price each, 35c; per doz., \$3.50.

2-inch pot plants.

Price each, $15 \mathrm{c}$; per doz., $\$ 1.50$.

SCARLET SHADES. One of the latest additions we are able to offer by way of color in our choice selected strain of Columbines. A few seasons ago we obtained a very fine scarlet, wherein the resultant seedlings have broken into scarlets, crimsons and similar shades. These are by all odds the most richly colored Columbines in the entire race. Flowers range through all the colors of light scarlet, dark scarlet, crimsons, etc., bearing the usual long spurred flower, broad open cups and sepals with many handsomely bi-colored types manifesting themselves in the selection. Visitors to our Rivera nursery last season were greatly taken with the large block of these plants when in full flower. It was hard for many to realize that so many fine colors were obtainable in this handsome herbaceous plant. We can unhesitatingly recommend this new selection to all of our customers with the assurance that those who enjoy a sterling novelty in plants will be more than pleased. We have only a limited stock of this strain to offer this year. Strong $2 \mathrm{~T} / 2$-inch pot plants. Price each, $25 \mathrm{c}$; per doz., $\$ 2.50$. Strong field grown clumps. Price each, 35c; per doz., $\$ 3.50$.

\section{Agathea}

COELESTIS. Commonly known as the Blue Marguerite. A charming old-fashioned plant which blooms continuously throughout a long period. Dwarf in habit. A splendid border plant for large beds.

Price each, 15c; per doz., \$1.50.

\section{Anchusa}

ITALICA (Dropmore Variety). A recent and noteworthy addition to the list of hardy plants. Does best in partial shade. Flower stems attain a height of 6 feet. The flowers are a superb shade of pale blue, not unlike a giant Forget-Me-Not. Extra fine stock.

Price each, 35c; per doz., $\$ 350$. 


\section{Anemone Japonica}

The lovely Japanese Wind-Flowers are amongst the most beautiful of all our Fall flowering plants; as cut flowers they last exceedingly well, and there are few plants more attractive or graceful in herbaceous borders. They bloom in wonderful profusion from August until late Fall, the plants attaining a height of four to five feet and being literally smothered with flowers. They require a partially shaded northern aspect for best results, with plenty of water and an occasional mulch of rotted manure.

GIANT BLANCHE. A splendid pure white Anemone with semi-double flowers of very large size. The petals are of snowy whiteness. Unquestionably the finest of all the pure white hybrids in this lovely class of Fall flowering plants.

Price each, 20c; per doz., \$2.00.

HUPENSIS. A miniature form of the ordinary Anemone japonica. The plants attain a height of some 24 inches and produce in lavish profusion during the Fall months handsome mauve rose-colored flowers. The blossoms are single and are disposed in handsome branching trusses.

Price each, 20c; per doz., \$2.00.

QUEEN CHARLOTTE. A hybrid between Anemone japonica alba and Anemone japonica rosea. Flowers very large, semi-double in form, and a most pleasing silvery pink in color. The flowers are borne in large whorls on stems four to five feet high and are produced in lavish profusion from early until late Fall. Excellent for cutting purposes and a beautiful subject in a herbaceous border. Price each, 20c; per doz., $\$ \mathbf{2 . 0 0}$.

\section{Armeria \\ (Sea Pink or Thrift)}

ROSEA. A useful rockery or border plant bearing innumerable dense heads of beautiful pink flowers on stems nine to ten inches high. This Armeria flowers continuously over a long period and being quite hardy is especially suitable for early Spring and Summer bloomirg. Fine strong plants.

Price each., 20c; per doz., $\$ 2.00$.

\section{Asters-Perennial}

Aside from their value as a garden plant, there is nothing we know of more artistic and beautiful than the cut sprays of Perennial Asters used in association with flowers of heavier nature. Exquisite effects may be obtained by using them in conjunction with other flowers in Spring baskets, etc. They lend a grace and delicacy to floral arrangements of all kinds and have the property of being splendid keepers when cut. Well established clumps of Perennial Asters bloom season after season with little or no attention beyond the use of an abundance of water and an occasional mulch of well-rotted manure. The collection we offer you below comprises some of the finest varieties introduced to date and are nearly all of English origin.

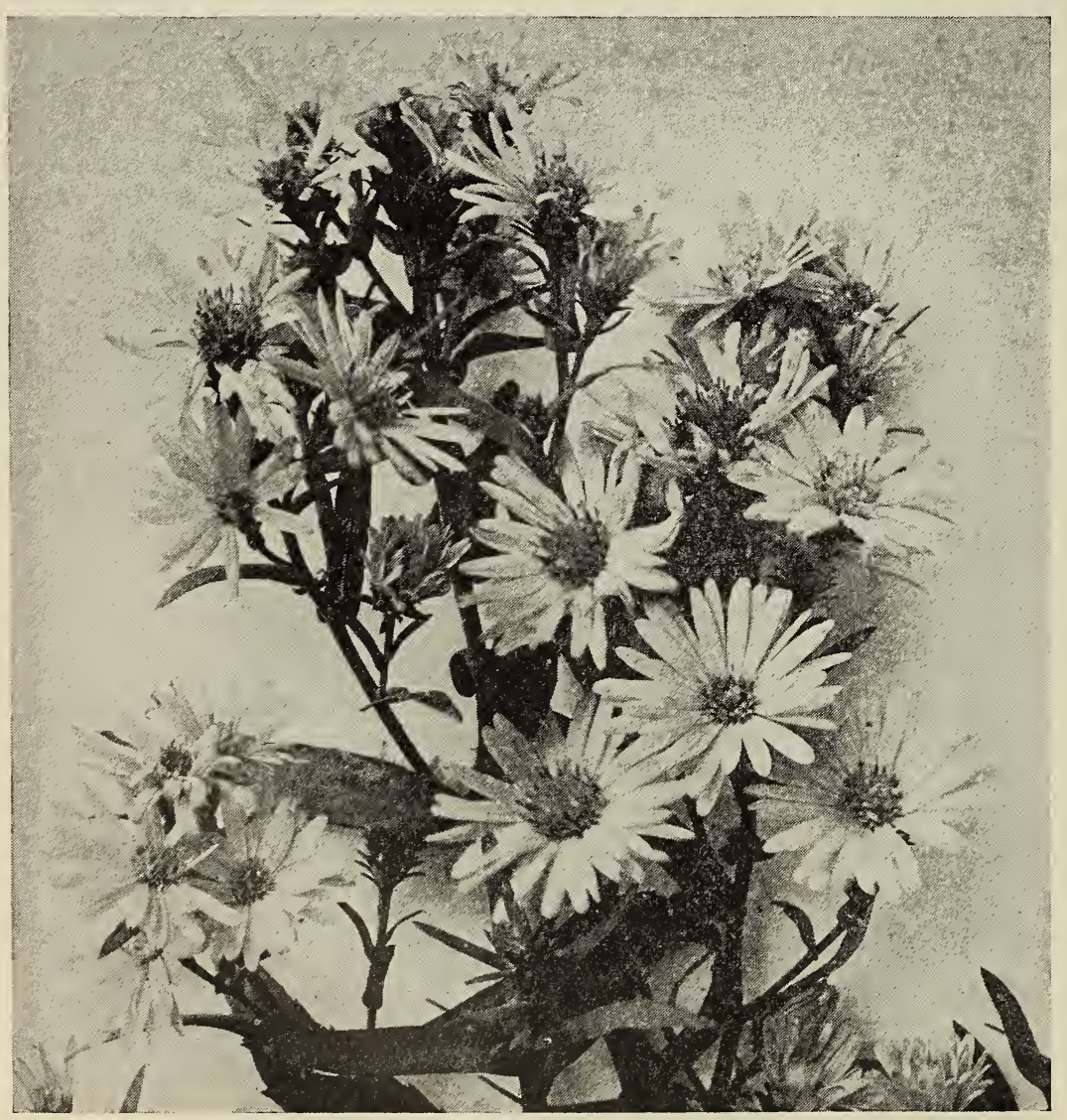

ABENDROTE. Lavender shading to carmine.

BEAUTY OF COLWALL. A distinct dark blue semi-double variety. Very handsome.

BLUE GEM. All that its name im plies. Rich bright blue. Very fine.

CLIMAX. A pure even shade of clear light blue and one of the largest flowers of all Perennial Asters.

EARLY PINK. Dainty starry flow: ers of a beautiful rosy carmine pink color.

FELTHAM BLUE. Masses of pure blue flowers, produced in great profussion on strong pyramidal spikes.

FINCHLEY WHITE. A splendid pure white of moderately tall growth.

GLOBE d'AZUR. Pure azure blue. Flowers of moderate size, produced in dense masses. A variety of great merit.

ROBINSON V. C. A handsome seinidouble with beautiful bright mauvecolored flowers.

SAM BANHAM. Produces dense masses of large feathery pure white flowers. Very early.

ST. ERWIN. Rosy lavender. Dwarf and compact. A fine variety for low borders. 


\section{BEGONIAS}

\section{Fibrous Rooted Varieties}

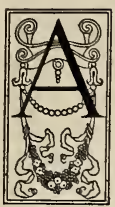

SPLENDID selection of Begonias comprising many sorts that vary in character, both as regards height, type of bloom, etc. This class of Begonias is wonderfully effective when used in shady beds in conjunction with ferns and are equally adaptable for use in rock gardens. In general they are tender subjects and will not withstand much frost. They should be planted in a well-prepared soil and one which contains plenty of humus.

ASCOTIENSIS. An elegant free-flowering Begonia of the Fuchsioides type which blossoms profusely throughout the entire year. Flowers a peculiar shade of Indian red in color. Very handsome and attractive, owing to the long period of bloom.

Price each, 35c.

ARGENTEA GUTTATA. A beautiful variety with all of the leaves dotted with silvery white spots on a purplish bronze ground, with underneath portion of the leaves a rich coppery red. Does particularly well in open beds in a shady position.

Price each, 35c.

FEASTII. A handsome dwarf fibrous rooted species with rich, round, reddish-colored foliage bearing splendid spikes of beautiful pure pink flowers. This variety is very dwarf in habit eminently adapted for use in ferneries, rock gardens, etc. This lovely species is particularly beautiful in early Spring when the plants are simply a mass of pure pink blooms. Price each, 35c.

FUCHSIOIDES. An elegant type with pendulous branches and deep rose pink flowers. Very suitable for extremely shaded locations.

Price each, 35c.

GLAUCOPHYLLA SCANDENS. An exceedingly handsome Begonia of climbing habit, bearing large trusses of bright coral red flowers. Foliage dark green and of moderate size. A splendid variety for hanging baskets or for covering the walls of greenhouses, etc. This species is somewhat tender and will not stand much frost.

Price each, $\mathbf{5 0 c}$.

HAAGEANA. One of the most noteworthy varieties in our collection. Foliage large, silvery white on the upper surface, dark red underneath. Blossoms very large. Color, white, daintily stained with rosy pink. A very fine sort. Strong, 4-inch pot plants. Price each, 35c.

LUCERNE. A very tall growing variety. Produces enormous canes which attain a height of 6 to 7 feet. Flowers are borne in immense panicles. The individual flowers are large and of a superb shade of deep rosy pink. Uundoubtedly one of the best of all tree Begonias. Strong plants in 4-inch pots. Price each, 50c.

PRESIDENT CARNOT. This beautiful Begonia is the parent of most of our best tree Begonias. A very vigorous grower with handsome foliage and enormous panicles of deep rose-colored blossoms. A magnificent variety. Strong plants.

Price each, 50c.

RUBRA. A very rapid grower and when fully developed it is covered from top to bottom with medium size panicles of bright scarlet blooms. Foliage bright green in color and quite smooth. Makes a splendid specimen as a pot plant. Strong, 4-inch pot plants. Price each, 35c.

\section{Semperflorens Type}

The varieties of this class produce elegant effects planted on the margin of beds as a setting to taller plants and throughout the year are a veritable mass of color. For low bedding purposes they excel all others, as there is not a time during their blooming period that they are not covered with bloom. The plants attain on an average a height of about 10 inches.

\section{Two Very Fine New Varieties}

CHRISTMAS CHEER. A very large flowered variety, the blossoms attaining a diameter of some 2 inches. In color dark crimson scarlet. One of the finest bedding varieties which has ever come to our notice.

Price each, $15 \mathrm{c}$; per doz., $\$ \mathbf{1 . 5 0}$.

CHRISTMAS PINK. A splendid companion to the foregoing variety. Blossoms, foliage and growth identical, differing only in color, the latter being a delightful shade of warm rose pink. Price each, 15c; per doz., \$1.50.

GRACILIS ALBA. Pure white with large waxy flowers. It combines dwarfness with an excellent compact habit. Price each., $15 \mathrm{c}$; per doz., $\$ \mathbf{1 . 5 0}$.

GRACILIS LUMINOSA. Bronze foliage with rich crimson colored flowers. A lovely variety.

Price each, 15c; per doz., $\$ \mathbf{1 . 5 0 .}$

GRACILIS ROSEA. Clear, waxy pink. A very fine companion to the above. Price each, 15c; per doz., \$1.50.

\section{Canterbury Bells}

These charming old-fashioned plants are favorites with all and are among the most beautiful of our Spring flowers. They may be flowered in pots, and when so grown are extremely pretty, their large bell-shaped flowers showing to great advantage. We can supply these in a very high-class strain of the true cup-andsaucer type in all colors, including pure white, rose, blue, etc. Strong plants from 3 -inch pots.

Price each, 20c; per doz., $\$ \mathbf{2 . 0 0}$.

\section{Chaenostoma}

HISPIDA. A dainty dwarf border plant. Ideal for rockery work. Attains a height of 6 to 10 inches. Foliage small, plants covered with minute white flowers throughout the year. Price each, $15 \mathrm{c}$; per doz., $\$ \mathbf{1 . 5 0}$.

\section{Coreopsis Lanceolata}

GRANDIFLORA. A splendid plant for cut flower purposes, being covered for the greater portion of the year with endless quantities of golden blooms 2 or 3 inches across. Fine, strong plants.

Each 15c; per doz., \$1.50. 


\section{Coreopsis Lanceolata}

\section{Perry's Variety}

A grand addition to the list of new herbaceous plants of English origin. The flower has the same rich golden yellow color as the parent type, Coreopsis lanceolata grandiflora. It flowers with equal profusion, but has a distinct advantage in the fact that the blooms are semidouble and in some instances almost double in character. The stems are long and wiry, attaining a length of some 18 inches. The flowers are very large with the petals beautifully notched and ruffled. There is a grace and beauty about this new Coreopsis which will make it extremely valuable as a cut flower proposition and it is equally good for producing stretches or masses of golden yellow in the garden. It is one of those superlatively good things that everyone interested in plants should have. The clumps are biennial in their character and will blossom freely for two years without resetting. After this time, it is advisable to divide them and plant in new quarters.

Price each, 25c; per doz., \$2.50.

\section{Cuphea}

PLATYCENTRA. A compact, bushy plant bearing quantities of small tubular flowers, the lower part of which are bright scarlet merging to maroon and white at the tips. A splendid bedding plant, as it blooms incessantly. Requires a warm, sunny position.

Price each, 15c; per doz., $\$ 1.50$.

HYSSOPIFOLIA. A comparatively little known border plant, but one of great beauty and worth. It equals boxwood as an edging plant and has the additional advantage of being constantly in bloom. The flowers are minute in size and in color a distinct shade of violet blue. Strong, young plants from 2 -inch pots.

Price each, $15 \mathrm{c}$; per doz., $\$ 1.50$; per $100, \$ 10.00$.

HOOKERIANA. A superb Cuphea. One which is but little known. It produces dense panicles of flowers and attains a height of 2 to 3 feet. A novel and striking plant. Color, vermilion and orange. Extra strong stock.

Price each, 35c; per doz., $\$ 3.50$.

\section{Delphinium-Perennial Larkspur}

Our strain of Delphiniums contains a wide selection of all the best shades of blue, ranging from the palest sky blue to indigo, sapphire, dark blue and purple. For producing a fine mass of blue Delphiniums are unequaled, and the fact that with the return of each season there is an increased quantity of bloom and added wealth of color has made them popular in gardens everywhere.

The clumps which we offer you are fine two-year-old stock, which, if planted out early in the Spring, may be depended upon to give a wonderful show of color during the following Summer season.

\section{Delphinium Belladona}

\section{$\mathrm{H} \& \mathrm{~S}$ New Selection}

This beautiful Delphinium is unquestionably one of the most useful of all. It is quite distinct in character of growth from the Elatum types, being much dwarfer, branching freely from the base and producing throughout the season an uninterrupted show of medium sized spikes of bloom. The stems are thin and wiry, the blooms large and beautifully poised on well-arranged spikes. The blue which we have finally fixed in this strain is one of the loveliest shales of sky blue to be found in any flower. This Delphinium should be largely planted as it gives an unlimited supply of handsome spikes in a fixed and well-defined color, from early Spring to late Autumn. The $\varepsilon$ are many strains of this Delphinium on the market, but we question, however, if there is anything superior to these which we are able to offer you for the first time this season. It is a selection far and away ahead of what we have offered before. We are certain it will please you. Strong one-year clumps. $\quad$ Price each, 35 ; per doz., $\$ 3.50$.

HOWARD \& SMITH NEW HYBRIDS (Elatum Type). There are perhaps few subjects in the way of herbaceous plants more sought after or more greatly admired than Delphiniums and but few classes of plants in existence wherein so many shades of blue are manifested. The strain we offer is not only replete with a range of remarkably handsome shades, but has the additional quality of giving individual florets of immense size and handsomely formed spikes. The colors range from palest sky blue through such shades and colors as indigo, sapphire, dark blue, purple, turquoise, mauve, amethyst, violet, corn-flower blue, etc. The handsome flowers are well placed on the spikes and the spikes on well-grown plants attain a height of six feet or over. Our selection will be found particularly free from dark, objectionable smoky purples, etc., so common in many ordinary strains. They include also the single, semidouble and quite double forms. A strain of unquestioned worth, the result of many years of careful selection and careful hybridizing. Fine, strong one-year clumps, including all colors mixed. Price each, 35c; per doz., \$3.50.

\section{New Gaillardia "Portola"}

This magnificent new Gaillardia is easily one of the grandest introductions in perennial plants that has come to our notice during the past ten years. It bears blossoms of enormous size, four to five inches in diameter, on individual stems two feet and over in length. The blossoms are of a remarkable shade of rich, bronzy crimson, the tips of the petals being margined with a broad band of golden yellow.

As a cut flower or for garden decorative purposes this new Gaillardia is without a peer in the whole range of perennial plants. The Gaillardia Portola blossoms freely under all conditions of weather. Plants put out now will produce a continuous succession of beautiful long-stemmed flowers from June through the Autumn and Winter months. The blossoms retain their beauty for several days and will be found unequalled for use in vases, etc.

The general color effect of a bunch of the cut blooms is true Egyptian red, toned with yellow. There is a glow and sheen about the flower almost impossible of description. It is remarkable, not only for the oddity of its color, but for the richness of its effect.

Price each, 20c; per doz., $\$ \mathbf{2 . 0 0}$. 


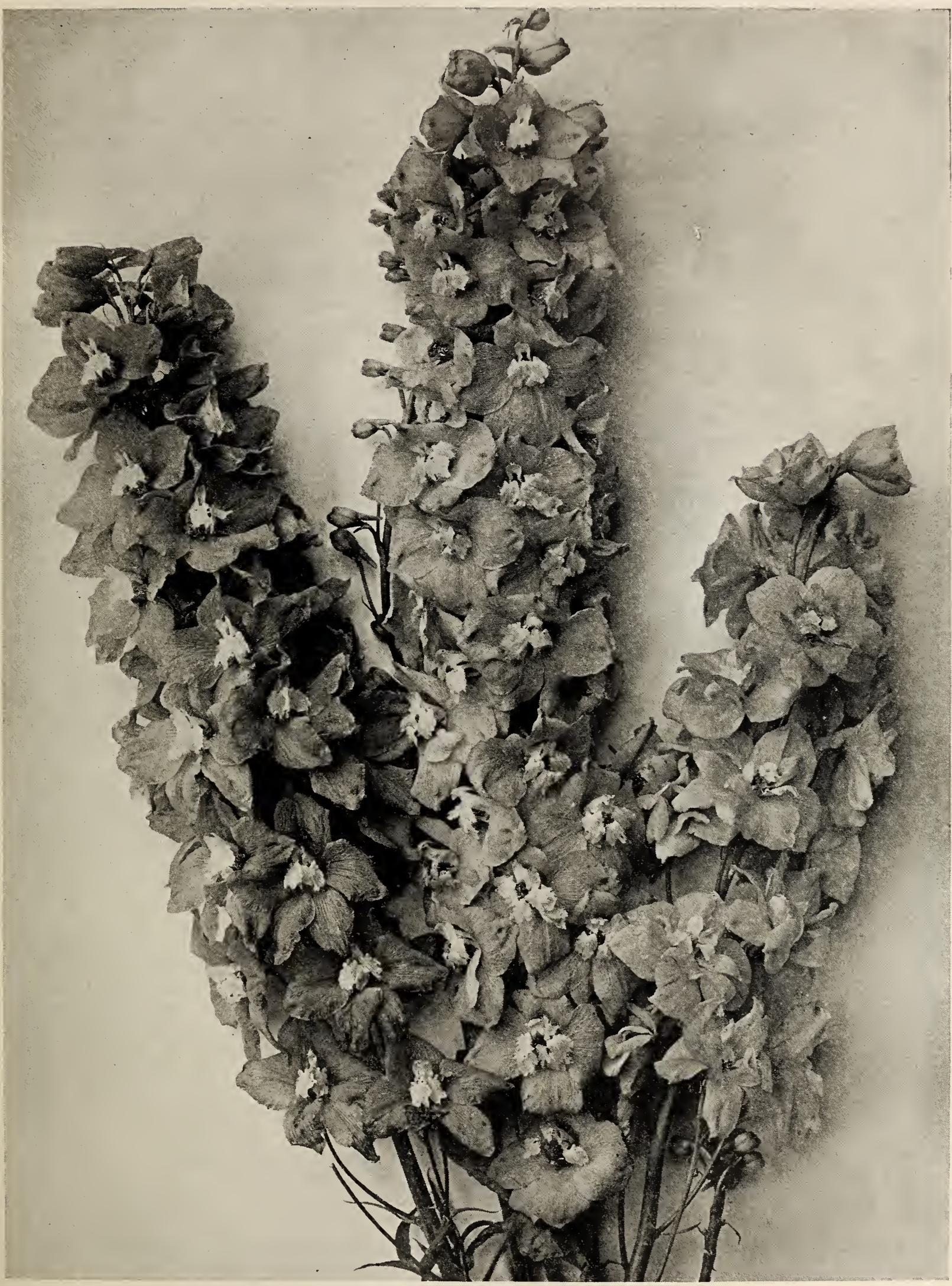




\section{Gaillardia}

HOWARD \& SMITH'S NEW GIANT FLOWERED STRAIN. It is with pleasure that we direct your attention to this superb new strain of Gaillardia. They are the grandiflora type and bear flowers of enormous size in a wide range of colors. Composing this series are pure golden yellows, rich bronze selfs, bi-color varieties, wherein beautifully zoned flowers of golden yellow and red, bronze and yellow, bronze ground tipped with yellow, etc., are conspicuous. The blossoms are of enormous size, the flowers attaining a diameter in many instances of five inches and over, and occur in beautifully ruffled, frimbriated and fringed types. For cut flower purposes this new strain is unequalled by any we have ever seen. They will blossom in this climate from early Spring right through the Winter season, furnishing an abundance of fine bloom over a protracted period. We cannot recommend them too highly. Strong young plants from 2-inch pots which will blossom freely this season.

Price each, 20c; per doz., \$2.00.

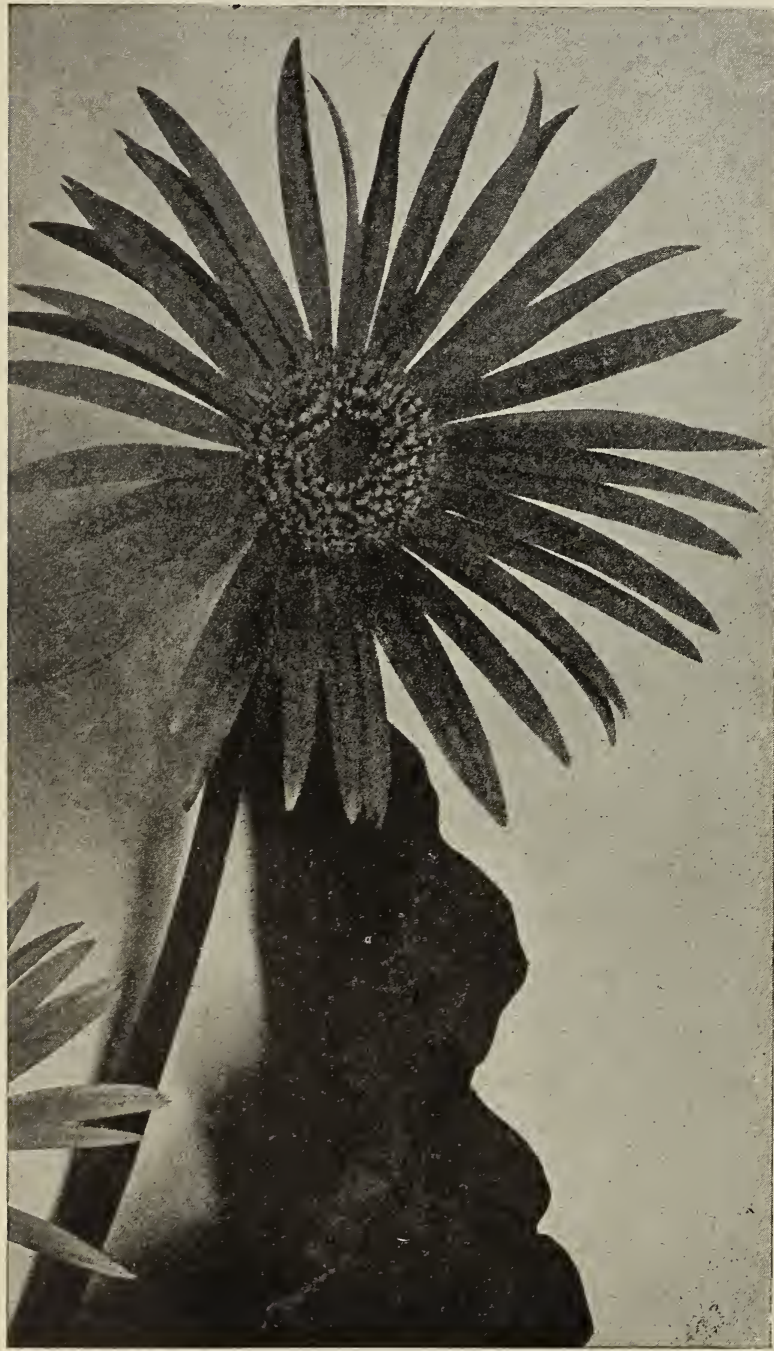

Gerbera-Iransvaal Daisy Greatly Reduced

\section{Gazania}

As an edging to borders or for planting in parkways Gazanias make a constant bright display from early Spring to Autumn. They are doubly valuable because of the fact that the plants continue to bloom season after season and require but little attention beyond an occasional dividing of the clumps. The plants attain a height of only a few inches; are surmounted with masses of flowers densely borne above the gray green foliage.

AURANTIACA HYBRIDS. A splendid new race of Gazanias with large broad petaled flowers which vary in color from almost pure white to deepest lemon, orange, etc. A splendid mixture of all colors.

Price each, 15c; per doz., \$1.50.

AURANTIACA YELLOW. Very large flower of bright sunflower yellow. Where a different color effect is desired this variety will prove very valuable.

Price each, $15 \mathrm{c}$; per doz., $\$ \mathbf{1 . 5 0}$.

AURANTIACA ORANGE. Intense California poppy yellow. A fine companion to the above, intensely brilliant in its effect when in full bloom.

Price each, 15c; per doz., $\$ 1.50$.

\section{Gerbera-Transvaal Daisy}

NEW FRENCH HYBRIDS. These handsome Gerberas are the result of crosses between the white South African variety and the well-known scarlet variety, Jamesonii. The strain contains all colors from purest white to deepest crimson, with intermediate shades of orange, yellow, pink, salmon, etc. Gerberas flower without intermission from early Spring to late Autumn. The flowers are borne on stiff, wiry stems. They are splendid for cutting purposes, retaining their beauty in a cut state for over a week. Extra fine clumps of blooming size.

Price each, 35c; per doz., \$3.50.

\section{HOWARD \& SMITH GIANT FLOWERED SCAR-} LET. A superb type of scarlet flowered Transvaal Daisy, bearing flowers of immense size. Intense glowing scarlet in color. It is easily one of the best types of this popular flower, the blossoms being freely produced from early Spring to late Fall. Plants grown in the colder sections of the country should receive ample Winter protection. Either greenhouses or cold frames will answer. Many people are unsuccessful in growing Transvaal Daisies. Lack of success in their culture is generally due to the fact that the crowns are planted too deep in the soil. The crown of the plant should be just even with the surface. If the soil collects in the heart of the plant, damping off will surely follow. It is advisable to plant them on ridges which serve to obviate this difficulty. Strong pot-grown plants.

Price each, 35c; per doz., $\$ 3.50$.

\section{Gypsophila}

PANICUlatA. This handsome Gypsophila is the variety which is commonly used by florists for mixing with bouquets, etc. The plant attains a height of 2 to 3 feet, are much branched and covered in the Spring with innumerable minute pure white flowers. This variety is often referred to as Baby's Breath. Strong, one-year clumps.

Price each, 20c; per doz., $\$ \mathbf{2 . 0 0}$. 
PANICULATA DOUBLE. A lovelv double form of the ordinary Paniculata type. Blossoms are quite double and are produced in the same feathery sprays to be noted in the foregoing. Of splendid value in cut flower work when associated with Carnations or other cut flowers. There is an air of delicacy and grace to this variety which will appeal to everyone. The trusses of bloom if cut before too well advanced can be dried and treated as an everlasting. Price each, 35c; per doz., $\$ 3.50$.

\section{Helenium}

The varieties offered below are of great value, not only as ornamental subjects in the garden, but when used for cut flower purposes. The blossoms are borne on immense trusses with stems 5 to 6 feet in height. They are exceedingly graceful when used in tall vases, either by themselves, or in conjunction with other flowers.
RIVERTON BEAUTY. Bright golden yellow. Petals of the blossoms beautifully crimped and serrated at the edges. A grand perennial. Price each, $20 \mathrm{c}$; per doz., $\$ \mathbf{2 . 0 0}$.

RIVERTON GEM. Similar in all characteristics to the preceding variety. Blossoms distinct shade of bronzy red and gold. Price each, 20c; per doz., \$2.00.

AUTUMNALE RUBRUM. A very desirable border plant, succeeding well in any soil in a sunny location. It has broad spreading heads of flowers and is exceedingly graceful. Of splendid value for cutting purposes. Blooms in August and September. Color, a bright terracotta red.

Price each, 20c; per doz., \$2.00.

\section{Helianthus-Perennial Sunflower}

We offer you four of the best Perennial varieties. During the season Perennial Sunflowers are a mass of golden yellow flowers. For color effects in the garden or for use as cut flowers

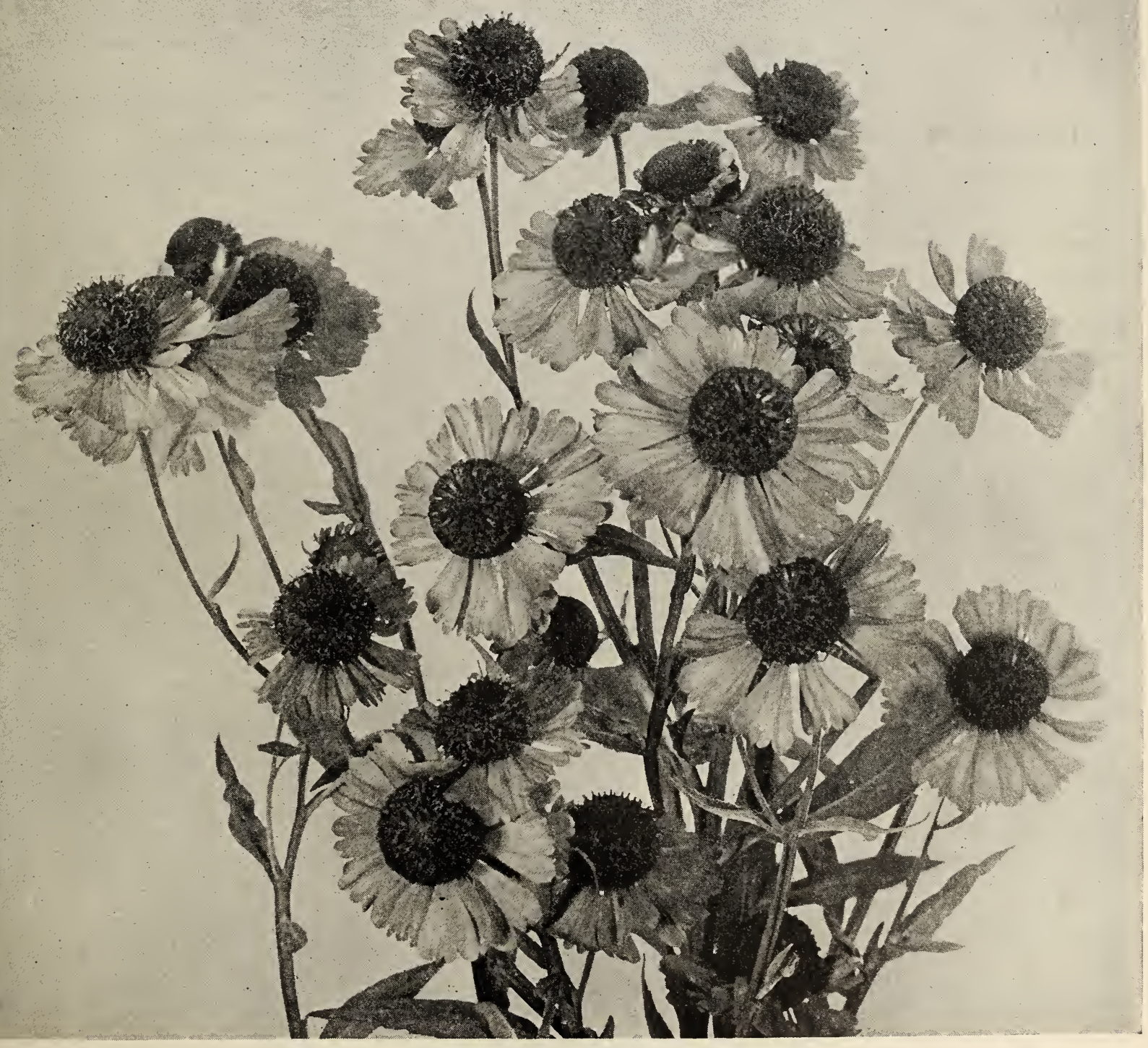


they are extremely valuable. They delight in good rich soil with plenty of water and full sun. The clumps are of Perennial duration and with the return of each Summer season, there is a recurrent display of masses of brilliant yellow flowers.

ANGUSTIFOLIA. A handsome Perennial Sunflower. bearing great masses of starry bright golden yellow flowers, like the variety multiflorus maximus. It is truly perennial in nature. In full growth they attain a height some 6 feet. A plant with splendid value as a cut flower.

Price each, 20c; per doz., \$2.00.

MAXIMUS. Covered with innumerable golden yellum flowers. For a color effect in the garden this variety is unsurpassed. It blooms from June until September. Also splendid for cut flowers. Price each, 20c; per doz., \$2.00.

METEOR. Similar to the above in foliage and height, but different in the shape of the flowers, the guard petals being somewhat wider.

Price each, 20c; per doz., $\$ \mathbf{2 . 0 0}$.

MISS MELLISH. A lovely single variety with cactusshaped blooms produced on stems 6 to 8 feet high. An excellent variety for cut flower purposes.

Price each, 20c; per doz., $\$ \mathbf{2 . 0 0}$.

\section{Hemerocallis-Japanese Day Lily}

For the margin of ponds or for planting in the open border these lovely Japanese plants are of special value. They form dense tufts of long narrow foliage surmounted by large trumpet-shaped blooms. They are of perennial duration and require but little care beyond watering.

\section{FIVE FINE VARIETIES}

AURANTIACA. Enormous flowers, very sweetly scented. Color, bright golden yellow.

Price each, 35c; per doz., \$3.50.

AURANTIACA MAJOR. An improvement on Aurantiaca. The largest flowered variety in the family. Color, rich orange.

Price each, 50c; per doz., $\$ 5.00$.

FLORHAM. A pure light yellow variety with medium-sized flowers. Blooms continuously from April to November. This variety is of especial value for herbaceous borders.

Price each, 35c; per doz., \$3.50.

SOVEREIGN. A medium shade of yellow. Blossoms of good size and freely produced.

Price each, 35c; per doz., \$3.50.

THUNBERGII. A late flowering sort. Blossoms are quite small, borne on slender stems. Color, a delicate shade of lemon yellow. Very sweetly scented. A veritable gem for rock work or for beds and borders.

Price each, $35 \mathrm{c}$; per doz., $\$ 3.50$.

\section{Hollyhocks}

The varieties which we offer have been carefully selected from our own prize collection. The flowers are of immense size, perfectly double and well arranged on tall, handsome spikes. We can supply them in the following colors: Pure white, yellow, rose, shell pink, dark crimson and cherry red. The clumps which we offer this season are strong one-year stock, which if planted early in the Spring may be depended upon to produce a glorious display during the following Summer. Extra long clumps. Price each, 35c; per doz., \$3.50.

\section{Hollyhock-Exquisite}

A lovely new strain of early flowering Hollyhocks bearing splendid spikes of double blossoms. The flowers instead of being smooth-petaled like those of the Chater class are beautiruily iringed and frilled on the edges. The individual blos. soms have more the appearance of a giant Carnation than a Hollyhock. Many superb bi-colored flowers are manifest in this strain and the range of colors to be noted is one of exquisite beauty and effect. This strain is one of the most outstanding additions to the list of herbaceous or biennial plants introduced in a long time. Strong, young plants, which will bloom this season.

Price each, 35c per doz., $\$ 3.50$.

\section{Hypericum}

MOSERIANUM. This handsome plant is generally classed under herbaceous plants, but in California it attains large size and is practically evergreen. It bears large numbers of bright golden yellow blossoms, 2 to 3 inches across. They are borne along the entire length of the gracefully arched stems. A fine thing for planting between mixed shrubbery or in herbaceous borders. Strong balled plants.

Price each, \$1.50.

Strong young plants from 3 - inch pots. Price each, 35c.

\section{Jacobinia}

COCCINEA. A pretty plant with dark green leaves, which attains a height of about 5 feet. It produces spikes of brilliant scarlet-colored flowers, and is of splendid effect in herbaceous borders. Fine, strong pot plants.

Price each, 50c; per doz., $\$ \mathbf{5 . 0 0}$.

\section{Leonotus}

LEONORUS. An elegant half-hardy perennial, brilliant orange-colored flowers. The plant is relatively referred to as "Lion's Tail." Extra strong plants from 3 -inch pots.

Strong, bushy stock.

Price each, 35c.

Price each, 50c.

\section{Libonia}

FLORIBUNDA. An exceedingly pretty dwarf evergreen plant, bearing numerous scarlet flowers, tubular in shape and produced in endless quantities throughout the year. Highly ornamental as a bedding plant aside from its value in the herbaceous border. Strong, young plants.

Price each, 20c; per doz., $\$ \mathbf{2 . 0 a}$

\section{Linum}

FLAVUM. A species of perennial flax with handsome golden yellow blossoms some 2 inches across. It grows to shrub-like proportions in this climate and flowers profusely throughout the year. A fine plant for dwarf borders. 


\section{Penstemons}

\section{New Giant Flowered Hybrids}

Although we have grown Penstemons for many years, these new hybrids far outdistance in size of bloom, in point of color series and general beauty, anything in this class of plants we have ever offered. The flowers are well disposed on the spikes and are of enormous size. The colors range from pure white to darkest crimson with the intervening shades of pink, scarlet, purple, rose, etc. All colors mixed, strong plants from 2-inchpots.

Price each, 20c; per doz., $\$ 2.00$.

\section{Erigeron-Quakeress}

This lovely new improved form of Erigeron has proven to be one of the daintiest and most useful herbaceous plants of recent introduction. The single starry asterlike flowers are a delicate shade of rosy lavender and are borne in profusion throughout the entire season, in this particular climate it has the distinct advantage of flowering during mid-winter or the early Spring months at which time there is usually a dearth of flowers in the garden. For cutting purposes this lovely new Erigeron is especial value.

Price, strong young plants each, 25c; per doz., $\$ 2.50$.

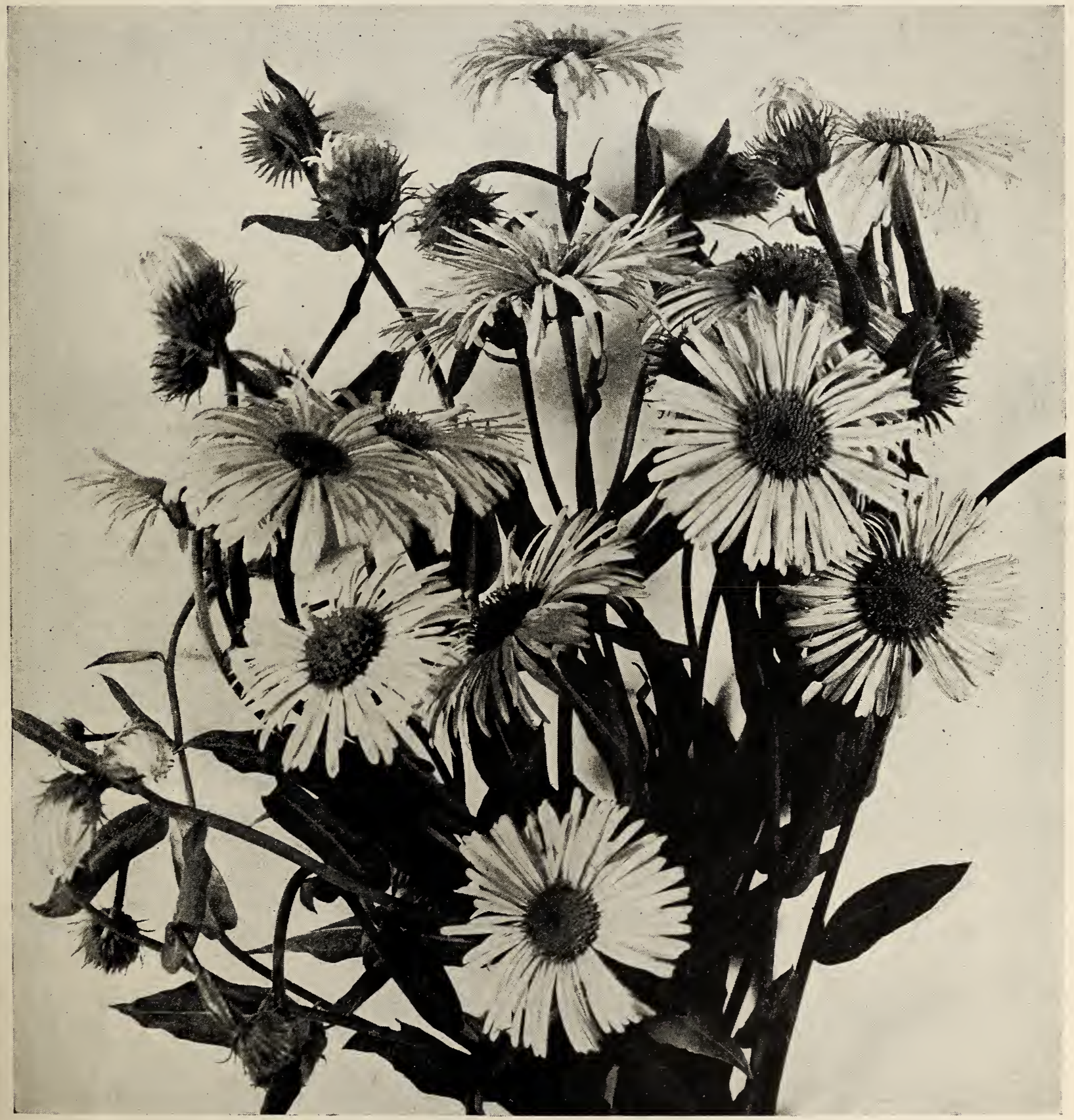




\section{Lopezia}

One of the daintiest subjects for Winter flowering in the whole range of blooming plants. The flowers are quite small, but borne in such profusion as to completely cover the plants.

ALBIFLORA. A pure white variety.

Price each, 20c; per doz., $\$ \mathbf{2 . 0 0}$.

ROSEA. A pure rose pink-colored variety.

Price each, 20c; per doz., $\$ 2.00$.

\section{Marguerites}

These well-known plants are favorites with all. They are of great value for border decoration, for planting along the margins of drives, etc. They bloom throughout the year in California and require but little care.

MRS. FRED SANDER. The finest of all double Marguerites. Produces large quantities of double, snowy white flowers. Strong plants.

Price each, 25c; per doz., \$2.50.

GIANT YELLOW. A splendid, deep golden yellow Marguerite. Flowers single. Fine for cutting purposes.

Price each, 20c; per doz., $\$ \mathbf{2 . 0 0}$.
Papaver Orientale New Giant Hybrids of the Large Flowered Oriental Poppies

These magnificent Poppies are unquestionably the most beautiful of all of the perennial species. In California they begin to bloom during the month of March with a continued display up to the end of June. Their impressive size and gorgeous colors place them in the front rank of flowering herbaceous plants. Once planted, the clumps increase in size and vigor season after season. They require little or no attention, but delight in a very rich soil and should be given an abundance of moisture during dry weather. The colors range from pure white to brilliant scarlet, orange, orange scarlet, dark rich maroon, salmon pink, etc. In some varieties the colors are pure self, in others heavily blotched black at the base of the petals. In some of the very large flowered sorts, the blossoms attain a diameter of 6 to 8 inches and nothing can be conceived in the floral line more impressive than these glorious plants, when in full perfection. Many of the varieties have beautiful frimbriated flowers, these latter being some of the more recent additions, especially in those of the apricot colored section. Strong plants.

Price each, 25c; per doz., $\$ \mathbf{2 . 5 0}$.

\section{Petunias}

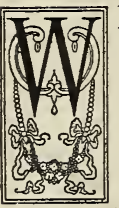

E HAVE devoted much work and careful attention to our strains of these beautiful subjects and from point of quality doubt if they can be excelled anywhere. They bloom without intermission during the greater part of the year and produce a very bright effect with a minimum amount of culture. When greenhouses are available, they make excellent pot plants for Winter blooming. The balcony class are splendid for porch boxes, the long pendant shoots being literally a mass of flowers over a period of several months. Petunias delight in a rich loamy soil and require a fully exposed sunny situation. The plants will last two seasons, but as they become rather woody after a single season's growth, it is better to procure new plants each year.

\section{H \& S Prize Double Mixed}

A grand selection of double Petunias in mixed colors, including all shades from pure white to dark crimson, comprising such colors as pure white, pink, crimson and rose, rose-edged white, mauve, steel blue and others. These Petunias have been carefully selected from hundreds of seedlings and will be found to have not only flowers of immense size, but beautiful form. The larger portion of them are deeply fringed or laciniated. All plants offered have been grown from carefully selected cuttings and will give maximum results. Price on any of the above mixed double varieties.

Price each, 20c; per doz., \$2.00.

\section{Ruffled and Fringed Giants}

These are the largest and most beautiful of all single Petunias. Blossoms attain a diameter of 5 inches and over and are of thick leathery texture with the edges beautifully ruffled and frilled. In some of the latter varieties the ruffles overlay, giving the flower the appearance of a double bloom. Those who want a strain with flowers of mammoth size will find this selection everything to be desired. The colors range from almost pure white to darkest crimson, with intermediate shades of rose, lavender, copper, etc. Many of the blossoms are two-toned, the outer margins of the petals being prettily marbled and penciled. Ready for transplanting to your garden for a Summer show of flowers April 15th. Extra fine plants from $2 \frac{1}{2}$-inch pots.

Price each, 15c; per doz., \$1.50.

\section{Single Fringed Petunias}

A grand strain of medium-size, compact growing bedding Petunias. The flowers are deeply fringed and ruffled, and although they are not large as to size, are borne so freely that they completely cover the plants. For general bedding purposes where a mass of color is required, we strongly recommend this strain. Ready April 15th.

Price each, $10 \mathrm{c}$; per doz., $\$ 1.00$.

\section{Giant Single Petunia-Ideal}

A lovely giant flowered ruffled and fringed Petunia. The color a delicate shade of rosy lavender penciled with maroon. The plant is a dwarf compact grower and will prove especially valuable for bedding purposes. Extra fine plants from 2" pots. Price each, 25c; per doz., \$2.30. 


\section{Two Very Fine Bedding Petunias}

The following varieties belong to the free-blooming dwarf bedding class. The flowers, although not large, are produced in such lavish profusion that for bedding purposes, where a definite show of color is desired in the garden they are without equal. We would advise the planting of these Petunias in solid beds, but they are equally adapted to use in edgings, borders, etc. They blossom without intermission from Spring until the following Winter. The plants in each instance are of neat compact habit.

ADMIRATION. One of the most unique and richly-colored of all petunias. Flowers of moderate size, deep violet blue in color, handsomely blotched with pure white. Strong plants from 3-inch pots.

Price each, 20c; per doz., \$2.00.

BRILLIANT ROSE. A lovely compact growing bedding Petunia. The plants attain a height of about one foot. There is a clarity of color produced in a mass effect planting of this Petunia which arrests the attention at once. One of the finest of all bedding Petunias. Strong plants from 3-inch pots.

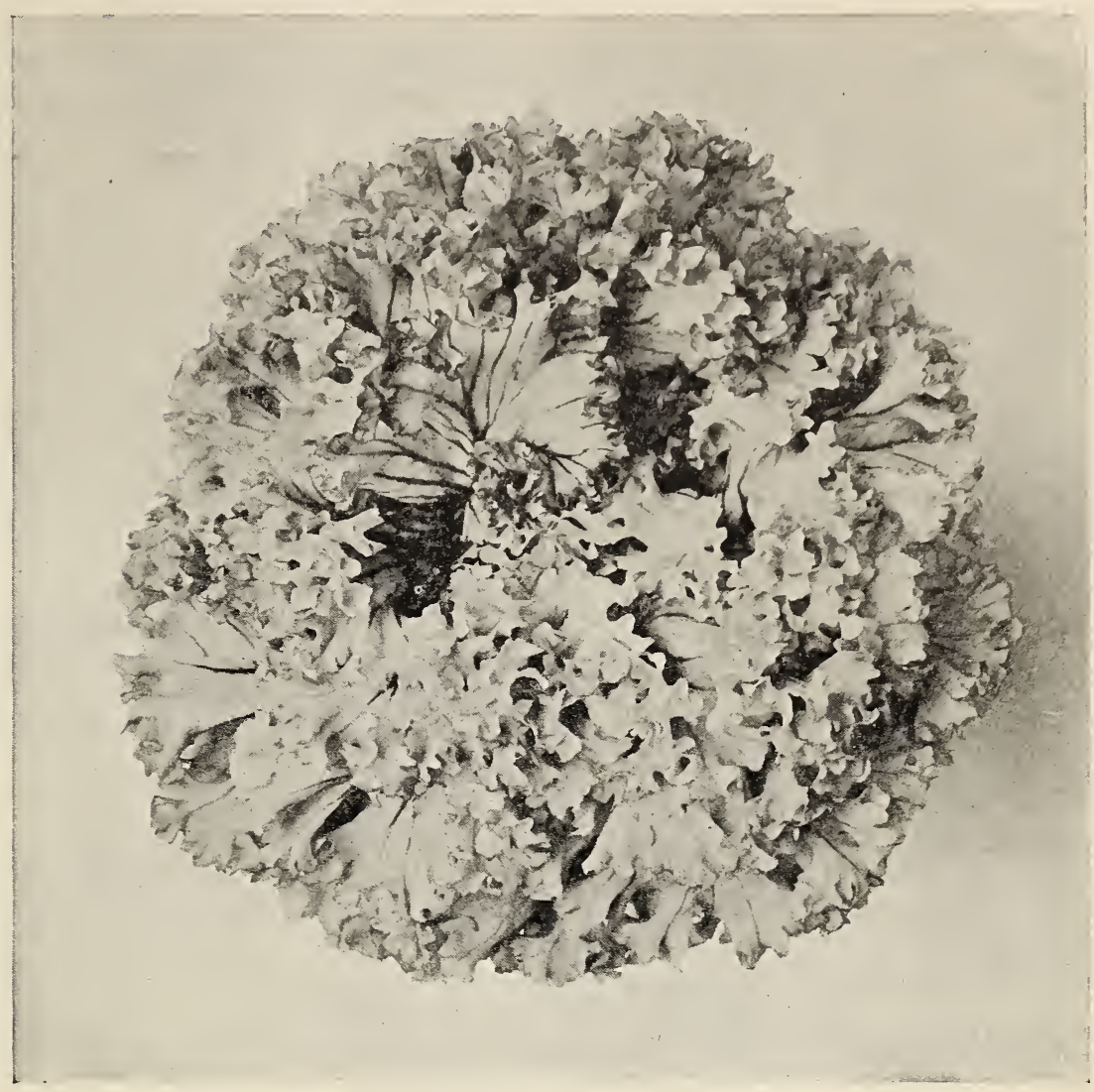

Petunia-Double Fringed

Price each, 20c; per doz., $\$ 2.00$.

\section{PINKS \\ New Hardy Ever Blooming}

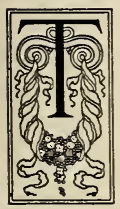

HERE have been but few novelties introduced in recent years more useful or beautiful than these superb new hardy Pinks from England. They are the result of crosses between the ordinary hot-house Carnations and the small border Pink. The flowers are intermediate in size between the Carnation and the border variety. These Pinks have a delightful clove fragrance. They are dwarf compact growers and blossom freely at all times of the year. A bunch of the cut flowers will scent a whole room.

These new Pinks are ideal for use as border plants in herbaceous borders. They blossom freely throughout the entire year, and at the height of their blooming season during Spring, produce veritable sheaves of flowers, and are splendid for cutting purposes.

HAROLD. A beautiful, deeply fringed, pure white flower, with intense odor. Splendid for cutting.

JOYCE. An exquisite shade of soft rose with a highly contrasting center or zone of dark maroon. Wonderfully fragrant. Long stemmed. A superb variety for cutting purposes.

MARY. Pale rose pink, with maroon colored center. An exquisite combination of colors. Very fragrant.

PEGGY. An attractive shade of rich crimson rose. The plants of this variety are extremely compact and bushy in their character. As an edging for beds and borders, it will prove extremely valuable. The color re- sembles in many respects that of the old hybrid Dianthus, Napoleon the Third.

PHYLLIS. Pale pink, with maroon colored center.

ROBERT. A very large flower. Ground color is old rose, with a deep maroon-colored center. A very desirable variety.

SUSAN. Delicate lilac zoned at the center of the flower with rich maroon.

Young plants from 2-inch pots, which will blossom during the coming Summer, ready April 1st.

Price each, 20c; per doz., $\$ 2.00$.

Price per 100 of any of the foregoing varieties, $\$ 15.00$. 


\section{Plumbago}

CAPENSIS. A handsome ever-blooming shrub, bearing dense trusses of coerulean blue flowers. In Southern California and other warm sections this plant is of special value as it blooms incesssantly. Is more or less prostrate in habit and makes an excellent cover plant for banks or may be used in the foreground of shrubbery planting. Strong plants from 4-inch pots. Price each, 35c.

CAPENSIS ALBA. A pure white form of the preceding with the same habit of growth. Differs only in color. Strong plants from 4-inch pots. Price each, 35c.

LARPENTAE. A very desirable dwarf, hardy form of plumbago. The plants only attain the height of 8 to 12 inches and are covered during the Summer and Fall with masses of deep, rich blue flowers. This species is deciduous during Winter. A tine plant for use in rock gardens, etc.

\section{Primula}

OBCONICA (New Hybrids). A beautiful strain with colors ranging from pure white to lavender, rose purple, etc. Always in bloom and well adapted to shady beds, etc. Young plants. Price each, $15 \mathrm{c}$; per doz., \$1.50. Strong plants, 3 -inch pots. Price each, 20c; per doz., 35c.

OBCONICA GIGANTEA. An elegant novelty with flowers far larger than any of its type. These are disposed in trusses, carried well above the sturdy dark green foliage. The leaves are arranged in rosette form and offer a fine setting to the graceful heads of bloom.

Price each, 15c; per doz., \$1.50.

MALACOIDES. A striking Primrose introduced from China several years ago. The flowers are borne around the central stem in dense whorls with several whorls to each stem. This lovely primrose is of great value for shady rockery planting, ferneries, etc. It blooms without intermission throughout the year. Strong plants from 2-inch pots.

Price each, 15c; per doz., \$1.50.

VERIS. The true old-fashioned English Primrose, in a very fine large flowered strain, containing all colors from white to dark crimson. The yellow and variegated types in the series are specially rich in color. These make excellent border plants for shady beds. They last for several seasons with an added quality to the display each year. Hardy and easily grown.

Price each, 15c; per doz., $\$ \mathbf{1 . 5 0}$.

\section{Pyrethrum}

ROSEUM. A splendid class of Winter blooming perennials, with large Marguerite-like flowers, produced on strong, wiry stems. Our strain includes all the colors from pure white to dark crimson, including rose, pink, etc. The foliage is fern-like and the plants are quite hardy. They bloom at a time when flowers are exceedingly scarce in the garden. Strong, young plants from pots in a strain of superb quality.

Price each, 20c; per doz., \$2.00.

\section{Rudbeckia}

GOLDEN GLOW. A well-known hardy perennial plant, producing during the late Summer and Autumn months immense quantities of beautiful golden yellow Dahlia-like flowers. The plants attain a height of 6 to 7 feet. Splendid for cutting purposes. Strong divisions.

Price each, 20c; per doz., $\$ 2.00$.

\section{Rudbeckia nitida}

AUTUMN SUN. A grand herbaceous perennial plant bearing masses of brilliant canary yellow flowers single in form. A fine companion to the variety Golden Glow. The cut blossoms are of superb decorative effect. The plants make a splendid back row flower in a herbaceous border. They attain a height of some 5 feet and are a glorious mass of flowers in Summer. The plants are truly perennial in nature, the clumps once planted blossom season after season.

Price each., 15c; per doz., $\$ 1.50$; per 100, $\$ 10.00$.

PURPUREA. An elegant type of dwarf Rudbeckia bearing during mid-summer, quantities of single rosy carmine blossoms. The plants attain a height of some 4 feet. Useful for cutting purposes. Price each 15c;

\section{Russelia}

per dozen $\$ 1.50$.

LEMOINEI MULTIFLORA. A lovely plant for baskets on account of its drooping habit. The small wiry stems are covered with small tubular coral red flowers. Extra strong plants in pots.

Price each, 25c; per doz., \$2.50.

\section{Sedum}

SPECTABILIS. Showy Sedum with thick, fleshy leaves and large heads of rich, rosy crimson flowers. The flower stem attains a height of some 18 inches. A unique rock or border plant. Price each, $35 \mathrm{c}$; per doz., \$3.50.

\section{Salvia}

AMERICA. This handsome dwarf bedding variety of the scarlet sage is unquestionably one of the finest of all bedding Salvias. If begins to blossom when the plants are quite small and continues right through the summer and autumn season. The plants attain a height of some 18 inches and are a glowing mass of brilliant scarlet. A splendid Salvia for beds or borders.

Price each, 15c; per doz., $\$ \mathbf{1 . 5 0}$.

FIREBALL. A bedding salvia of splendid dwarf habit, bearing quantities of brilliant scarlet flowers throughout the Summer and Autumn months.

Price each, $15 \mathrm{c}$; per doz., $\$ \mathbf{1 . 5 0}$.

PULCHELLA. A tall-growing variety bearing pretty red flowers during the Summer months. The flowers are quite small and abundantly produced. Plants attain a height of five feet. Price each, 25c; per doz., \$2.50.

LEUCANTHA. An exquisite species suitable for herbaceous borders. Flowers, a beautiful violet purple and white, borne in profusion from August to December. Ideal for cutting purposes. Strong plants from pots.

Price each, 25c; per doz., \$2.50.

RUTILANS. A variety of perennial duration, attaining a height of five feet, bearing an abundance of scarlet flowers late in the Fall. The foliage of this variety has a decided apple-like odor. Fine strong plants.

Price each, 35c; per doz., \$3.50.

\section{Shasta Daisy}

ALASKA. A dainty pure white Shasta Daisy with large beautifully formed single flowers. This variety is unquestionably one of the best of all Shasta Daisies for cut flower purposes. Fine, strong pot-grown stock.

Price each, $15 \mathrm{c}$; per doz., $\$ 1.50$. 


\section{New Shasta Daisy}

GLOIRE de VITRY. This magnificent new Shasta Daisy hails from France and is an outstanding variety in the giant-flowered section. The flowers are simply enormous, attaining a diameter of 6 inches or over. The petals are broad and strap-like, the yellow disc at the center of the flower comparatively small. The stems grow to a height of three to four feet, with the immense flowers beautifully poised at the tips. They last well in water and aside from the beauty of the clumps when in full bloom in the garden they are invaluable for cutting purposes. Nothing more beautiful can be conceived than a properly arranged basket of Spring flowers where this giant Daisy is used in conjunction with them. It is truly a sterling novelty and one which we can unhesitatingly recommend.

Price each, 35c; per doz., $\$ 3.50$.

\section{Fringed Semi-Double Shasta Daisies}

We introduced several seasons ago a series of double and semi-double forms of this well-known plant, but succeeded in raising two years ago an entirely new and superior form. The flowers are pure white, of very large size with the ends of the pecals deeply notched and cut, giving the whole bloom an informal and graceful fringed appearance. We feel quite certain it will prove a welcome addition to the herbaceous garden, either as a garden plant, or as a cut flower subject.

Price each, 25c; per doz., \$2.50.

\section{Solidago}

MISSOURIENSIS. A dainty dwarf form of Golden Rod, having more the appearance of a small flowered perennial Aster than a Golden Rod. The spikes of bloom attain a height of some 18 inches, the branching heads of bloom of spreading nature.

Price each, 25c; per doz., $\$ \mathbf{2 . 5 9}$.

PATULA. A variety of the common Eastern Golden Rod. The clumps are of perennial duration, increasing in size and vigor year after year.

Price each, 25c; per doz., $\$ \mathbf{2 . 5 0}$.

\section{Solidago Golden Wings}

A New Golden Rod Which Should Be in Every Garden

This lovely variety is a recent English introduction and one of sterling worth and beauty. The panicles of bloom, instead of being more or less pyramidal in shape, as most of our native species, are of spreading character more or less informal in their arrangement, the fully developed head of bloom being a foot and over in diameter, tassellike in its arrangement. A plant of this beautiful Golden Rod in full bloom might be likened to a fountain of gold, the yellow being of a rich and pronounced tone. It is a magnificent plant for the back row of the herbaceous border and we know of nothing more beautiful as a cut flower subject when used in epergnes or tall vases.

Price each, 35c; per doz., $\$ 3.50$.

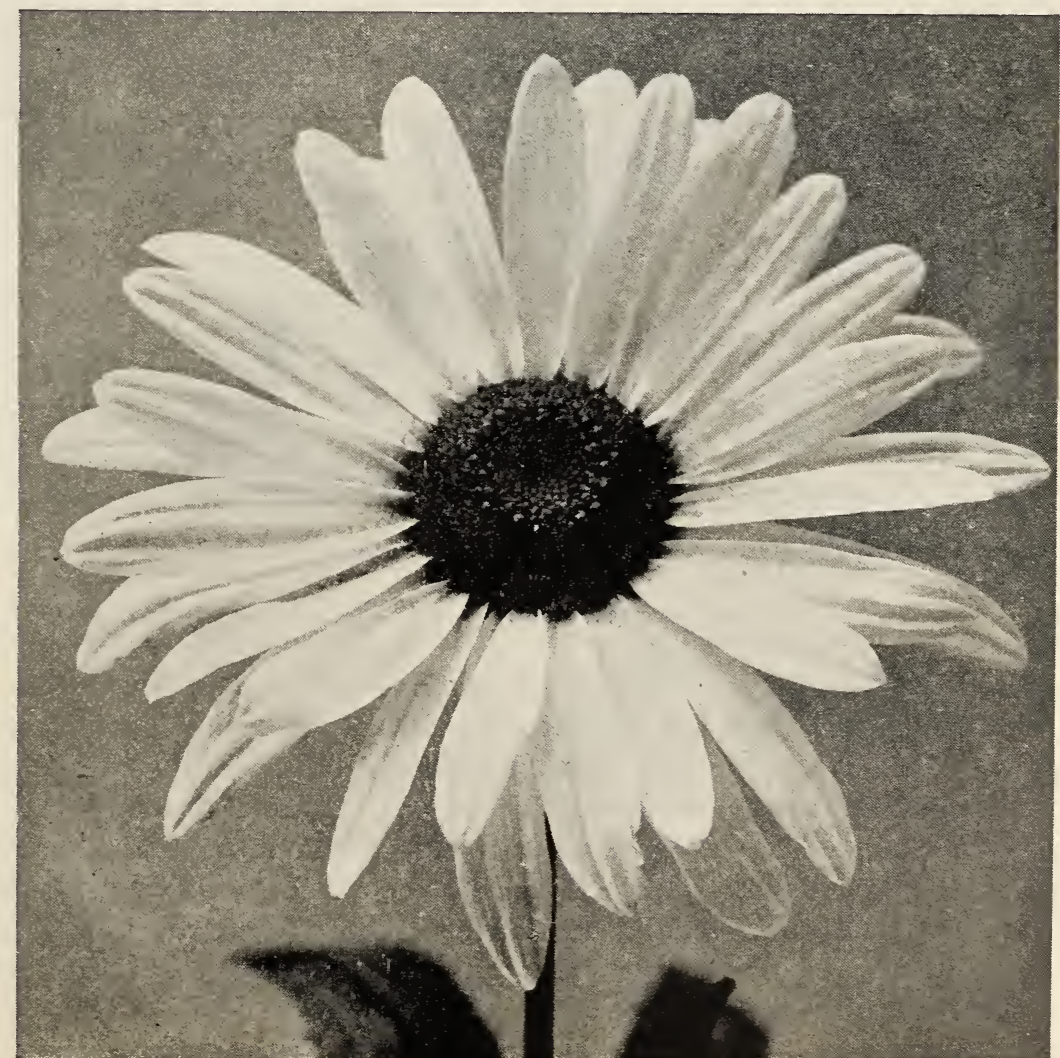

Chrysanthemum leucanthemum-Shasta Daisy 


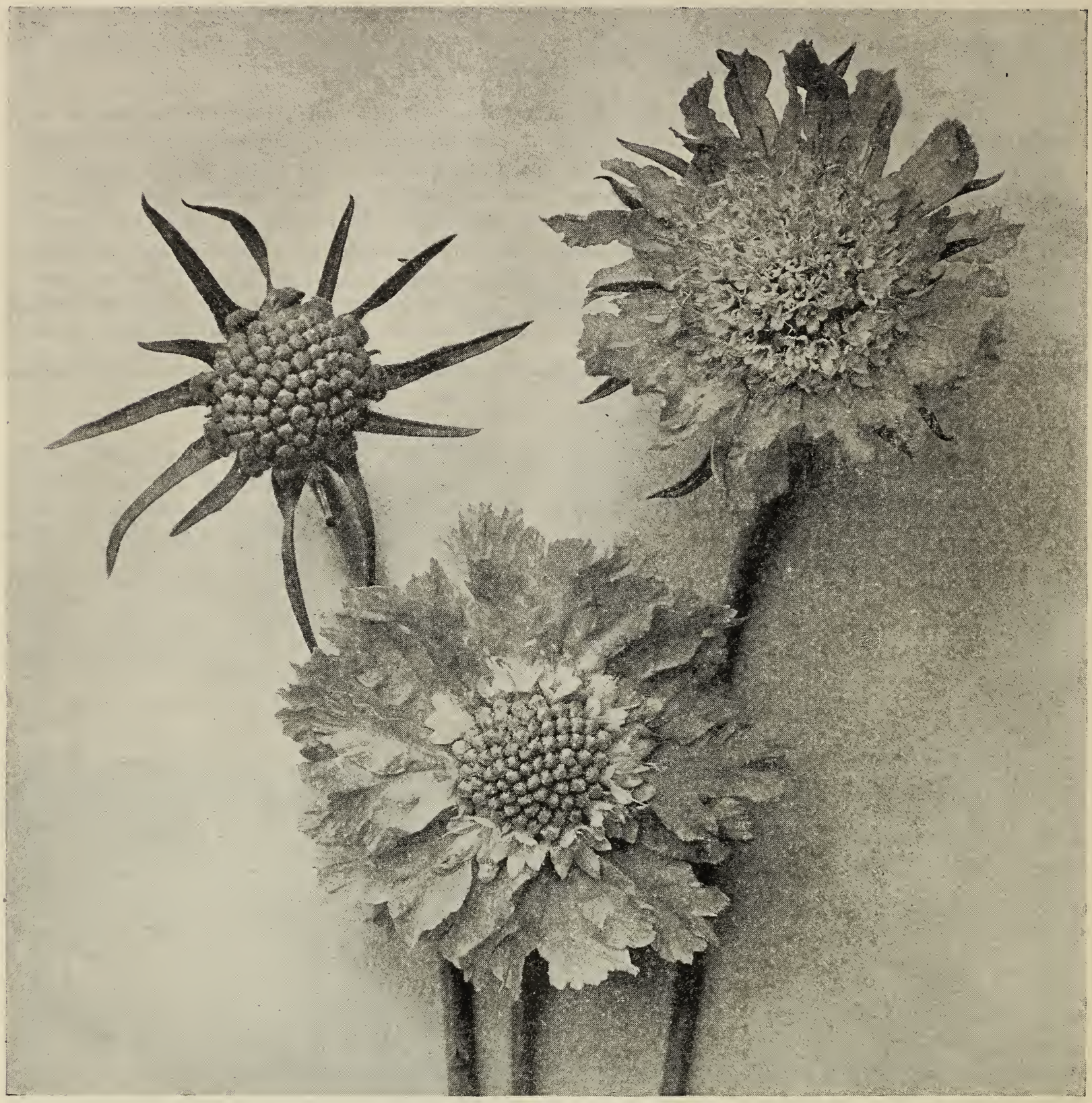

\section{Scabiosa Caucasica New Hybrids}

A superb new strain of hardy Scabiosa evolved from the well-known species of the same name. These new hybrids bear flowers on strong, slender stems, which reach a height of some two feet. The blossoms are beautifully frilled and lace-like in their appearance. They occur in single and semi-double forms. The colors range from pure white, sky blue, grayish blue, lavender, to dark blue. They are not only very large, but possess a grace and delicacy which, coupled with their splendid lasting qualities, make them indispensable as cut flower subjects. The strain we offer is absolutely unexcelled. In California they blossom right through mid-Winter and furnish an abundance of flowers at a season when flowers which can be cut from the open garden are scarce. Fine, strong pot-grown plants.

Extra heavy two-year-old balled clumps from the field.

Price each, 25c; per doz., $\$ 2.50$.

Price each, $50 \mathrm{c}$; per doz., $\$ 5.00$. 


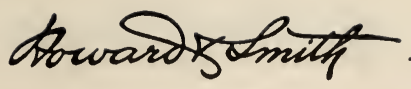

\section{Statice}

ARBOREA. A tree-like species of Statice which attains a height of some four feet. The flowers are a magnificent shade of violet blue, thick set in a truss that attains a diameter of 18 inches or over. Aside from its value as a cut flower, a specimen in bloom in the garden is one of the most striking of all plants. Strong young plants from $2 \mathrm{~T} / 2$-inch pots. Price each, $25 \mathrm{c}$; per doz., $\$ \mathbf{2 . 5 0}$.

LATIFOLIA. The great sea lavender. Leaves long and broad, forming a low growing tufted, rosette-shaped plant. From the center issues a branched growth completely covered with dainty pale blue flowers. A very valuable plant for bouquet work. Strong plants from 2-inch pots. $\quad$ Price each, 25c; per doz., \$2.50.

PEREZII. A handsome Statice of comparatively recent introduction. In general growth it resembles the variety Arborea, but the trusses of bloom are, if anything, larger and a brighter blue. The trusses of bloom of this Statice in common with many other species, can be used in the dry state for decorative purposes. This variety is particularly fine when used in combination effects with other cut flowers. Extra fine plants.

Price each, 35c; per doz., $\$ 3.50$.

\section{Tradescantia Wandering Jew}

VARIEGATA. A handsome foliage plant, the leaves of which are marked with creamy white. Can be grown in water for house decoration. Also valuable for wall pockets, hanging baskets, etc.

Price each, $15 \mathrm{c}$; per doz., $\$ 1.50$.

ZEBRINA. A handsome variety with distinct bronzy red foliage.

Price each, 15c; per doz., \$1.50.

\section{Tritomas}

For Summer and Fall blooming there are few plants more stately in appearance than well-grown clumps of Tritomas. Their large torch-like spikes of bloom, reaching up to a height of six feet, and fine grassy foliage, make them conspicuous objects in the garden. They associate well with the various grasses, cannas, etc., in jungle effects and do splendidly on the margins of artificial water courses and ponds. Once planted, they increase in beauty each season and require nothing more than plenty of water, any good garden soil, and plenty of manure.

CHRYSANTHA. Bright lemon yellow. Four to five feet high. Price each, 35c; per doz., $\$ 3.50$.

HENRY A. DREER. An extremely large flowered, tall-growing sort. Bright orange in color.

Price each, 50c; per doz., $\$ 5.00$.

PFITZERII. A constant blooming variety with spikes four feet in height. Orange scarlet.

Price each, 35c; per doz., $\$ 3.50$.

QUARTINIANA. A giant variety that attains a height of six feet or over. The color is orange red and yellow.

Price each, 50c; per doz., $\$ \mathbf{5 . 0 0}$.

R. WILSON KERR. Bright orange scarlet, with large spikes. $\quad$ Price each, 35c; per doz., \$3.50.

RUFUS. Medium in growth. Chrome yellow, passing to light yellow.

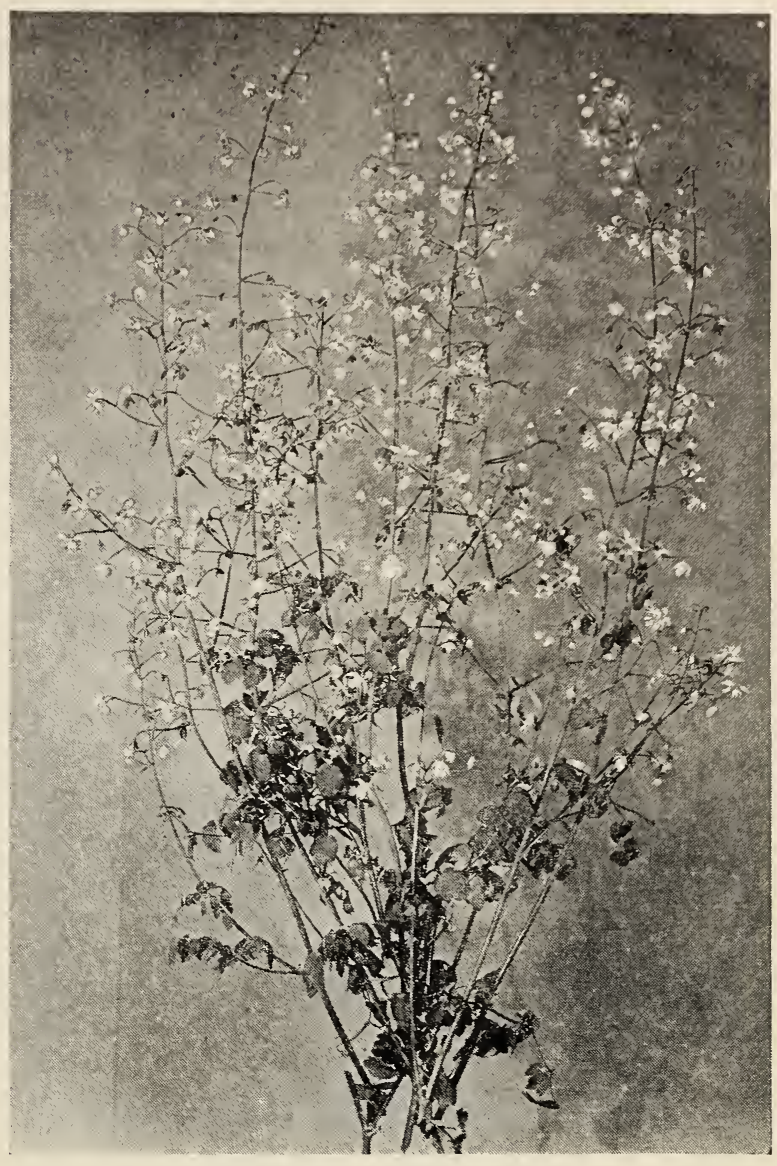

Thalictrum Dipterocarpum

\section{Thalictrum Dipterocarpum}

This plant was introduced several years ago, but is comparatively little known at the present time. Its intrinsic worth as an ornamental garden plant or as a subject for cut flowers is unexcelled, and it deserves a greater amount of recognition than it has heretofore received. The foliage is small, dainty in appearance and resembles in great measure that of the Maidenhair Fern. During its blooming period strong shoots ranging from four to six and seven feet high manifest themselves. These shoots are much branched and bear enormous quantities of minute bell-shaped flowers of a deep lavender color, the color being greatly enhanced by the yellow stamens in their centers. Strong flowering roots, each $35 c$;

\section{Violets}

per dozen, $\$ \mathbf{3 . 5 0}$

PRINCESS OF WALES. The largest single Violet in cultivation. Deliciously fragrant.

Price each, 10c; per doz., $\$ \mathbf{1 . 0 0}$.

MARIE LOUISE. Large, double blue flowers. Intensely fragrant and very free.

Price each, $15 \mathrm{c}$; per doz., $\$ 1.00$.

\section{Vitadena Triloba}

For covering unsightly banks or planting in parkways this species of Vitadena is of great value. It is a perennial plant of prostrate creeping habit and it is continually covered with small white Daisy-like flowers. Price each, 10c; per doz., \$1.00. 


\section{Novelties and Specialties in Choice Flower Seeds}

\section{Season of 1928}

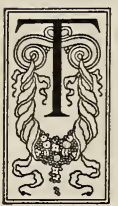

HERE is probably no feature in ornamental gardening which appeals more to the average layman, or even the more experienced gardener, than the use of the various annual, perennial and biennial plants as grown from seed for the embellishment of the garden. Vast improvements have been made in the various strains of choice flower seeds in modern times. So great has this improvement been, that strains and varieties which were in common use a decade or sn ago have practically passed from cultivation, giving way to the newer, better and more improved types.

In common with Roses and may other subjects, we have devoted a large amount of time and energy in the improvement of various strains of annual and perennial plants. The work which we have done on Asters and many other strains to be noted in the following pages covers a period of several years. Our one aim in the production of seeds has been quality and that our efforts in that direction have not been in vain is attested by the many voluntary reports we have had from customers from all parts of the world.

Our strains of Cinerarias, Giant Zinnias, Celosias, Verbenas and other subjects are recognized as being as near perfection as has been attained at the present time. The seeds which we send out are not only given careful germination tests, but a re subjected to trials to determine their trueness, etc. We feel certain that those who have not yet tried our various strains of seeds will be more than pleased with the results obtainable from them.

A selection from the varieties listed un the following pages will afford a variety of color and foliage that will brighten and beautify the garden, and fill the ever present need for cut flowers in the home.

\section{Acroclinium}

A pretty annual flower, everlasting in quality. Very effective in borders during its blooming season, with the additional advantage of being valuable in a dry state, for house decoration. Height, 15 inches. Double rose and double white.

Per packet, 10c.

\section{Ageratum}

These are easily grown from seed and will flower freely the same season as sown. Withstands the hottest Summers, but will not stand frost to any extent. Spring sown seed blooms 8 to 10 weeks after sowing. Splendid for carpet bedding, edging or pot work. We offer you two good, selections.

BLUE PERFECTION. A lovely shade of bright blue, uniform in color throughout the body of the flower. A very fine bedding variety.

Per packet, 10 c.

MAUVE BEAUTY. A dainty compact growing strain. Plants in full bloom are mounds of pretty mauve colored flowers which completely cover the plant.

Per packet, 10 c.

\section{Alyssum}

An exceedingly free blooming dwarf annual, unexcelled for use as a ground cover. Also available for carpet bedding or for edgings.

LILAC QUEEN. An especially fine selection of this beautiful dwarf Alyssum in a pretty shade of pale lilac. The plants are compact growers and create a grand mass of color within a short space of time after planting.

\section{Alyssum}

LITTLE GEM. A pure white form of dwarf prostrate habit, similar to Lilac Queen in every respect save color. Per packet, 15c.

\section{Amaranthus Salicifolius}

One of the handsomest of annual foliage plants. The foliage by way of color is a lovely combination of red and yellow, drooping in habit, and exceedingly effective when planted as an alternative with the ornamental varieties of Chilean Beet. Height, 2 feet. Per packet, 15c.

\section{Anchusa}

ITALICA (Dropmore Variety). A superb perennial plant which is easily raised from seed. The flowers are a beautiful shade of deep, rich blue. Borne in wonderful profusion on strong branching stems which attain a height of some 5 to 6 feet.

\section{Anchusa-Annual}

A distinct new variety of great merit, bearing innumerable quantities of beautiful forget-me-not-like flowers, on strong branching plants. The color is a pure shade of forget-me-not blue, easily grown from seed and producing during the Summer and Autumn months a veritable sheet of color.

Per packet, 15 c.

\section{Arctotis Grandis-African Daisy}

Pearly white, daisy-like flowers, shaded with delicate mauve at the tips of the petals. There are few flowers grown more valuable for cutting purposes. The flowers last a week or 10 days after being cut. Height, 30 inches. 


\section{Antirrhinum-Snapdragon}

\section{New Giant Maximum Type}

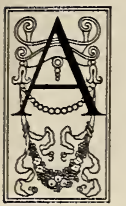

GRAND new strain of Antirrhinums or Snapdragons bearing blossoms of enormous size in a splendid range of colors. The flowers of this new strain are at least twice the size of those to be noted in the old majus class. The immense flowers are beautifully poised on strong stout spikes, the latter attaining when fully grown, a height of from five to six feet. As back row plants in herbaceous borders these Antirrhinums produce a most glorious color effect.

APPLEBLOSSOM. Glistening pink with white markings. A soft dainty shade.

Per packet, 25c. DEFIANCE. Rich glowing scarlet Per packet, 25c. DIAMOND. An exquisite shade of pure glistening rose. Extra fine.

FASCINATION. A deep flesh

Per packet, 25c.

Per packet, 25c.

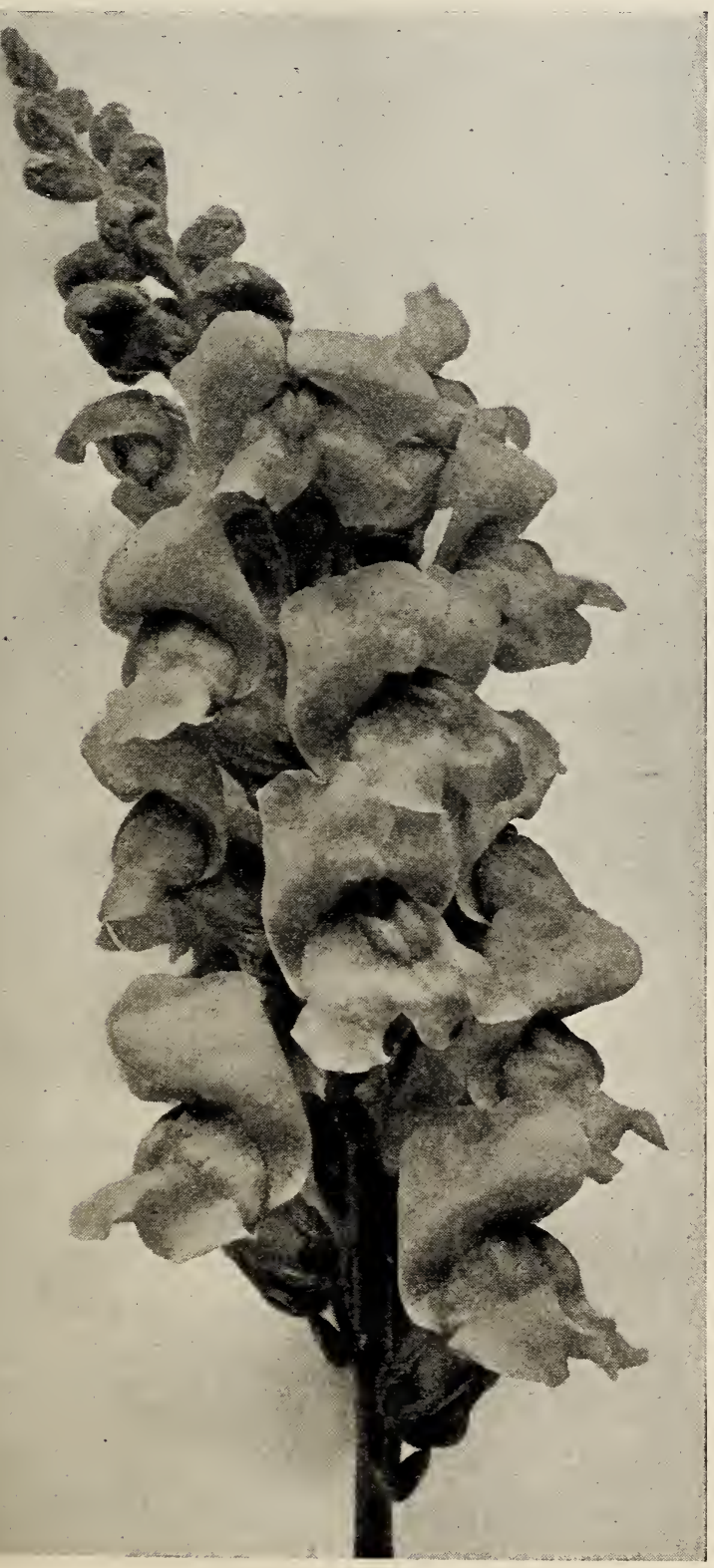

Antirrhinum Maximum
GOLDEN KING. Brilliant golden yellow of superb color effect.

Per packet, 25c.

GOTELINDE. Pale orange blotched lemon. on the lower lip of the flower.

Per packet, 25c.

MAHOGANY. Dark brownish red. Per packet, 25c.

SNOWFLAKE. Pure glistening white of even tone. Very large.

Per packet, 25c.

VENUS. Blossoms of giant size. Rosy white with the petals beautifully frilled at the edges. Per packet, 25c.

SPECIAL OFFER. One each of the above giant maximum type of Snapdragons for \$1.75. GIANT MIXED, all colors, including a well-balanced mixture of the above sorts.

Per packet, 25c.

\section{Three Very Fine Antirrhinums of Medium Height}

ROSE d'OR. An elegant shade of self salmon rose tinted with gold.

Per packet, 25c.

SALMON PINK. The color is a grand shade of pure salmon pink. The blossoms are of very large size densely placed on full rounded spikes.

Per packet, 25c.

WALLERS PINK. A lovely Snapdragon of a pure even shade of silvery pink. This is a fine companion to the foregoing variety.

Per packet, 25c.

\section{Dwarf Bedding Antirrhinums}

The following are suitable for low bedding purposes. The colors to be noted in all of the varieties are charmingly bright and fresh. They are very suitable for solid bedding effects in the garden.

AMBER QUEEN. A splendid shade of amber yellow.

Per packet, 15 c.

BONFIRE. Glowing orange scarlet. A wonderful shade.

Per packet, $15 \mathrm{c}$.

COTTAGE MAID. Pale pink with white throat.

Per packet, 15c.

CRIMSON KING. A splendid deep rich crimson.

Per packet, $15 c$.

FAWN. Terra cotta pink and pale yellow.

Per packet, 15 c.

NANUM MIXED. A choice mixture of all the best semi-dwarf Antirrhinums.

Per packet, $15 c$.

\section{Tall Antirrhinums}

The following three varieties are intermediate in height between those of the maximum and the dwarf or nanum class. The stems are of nice length for cutting purposes and are equally good for bedding.

FIREFLY. Bright scarlet with white throat.

Per packet, $15 c$.

PURPLE KING. Deep purple crimson.

Per packet, 15c.

QUEEN VICTORIA. Snowy white. Per packet, 15c.

MIXED. All varieties.

Per packet, 15c. 


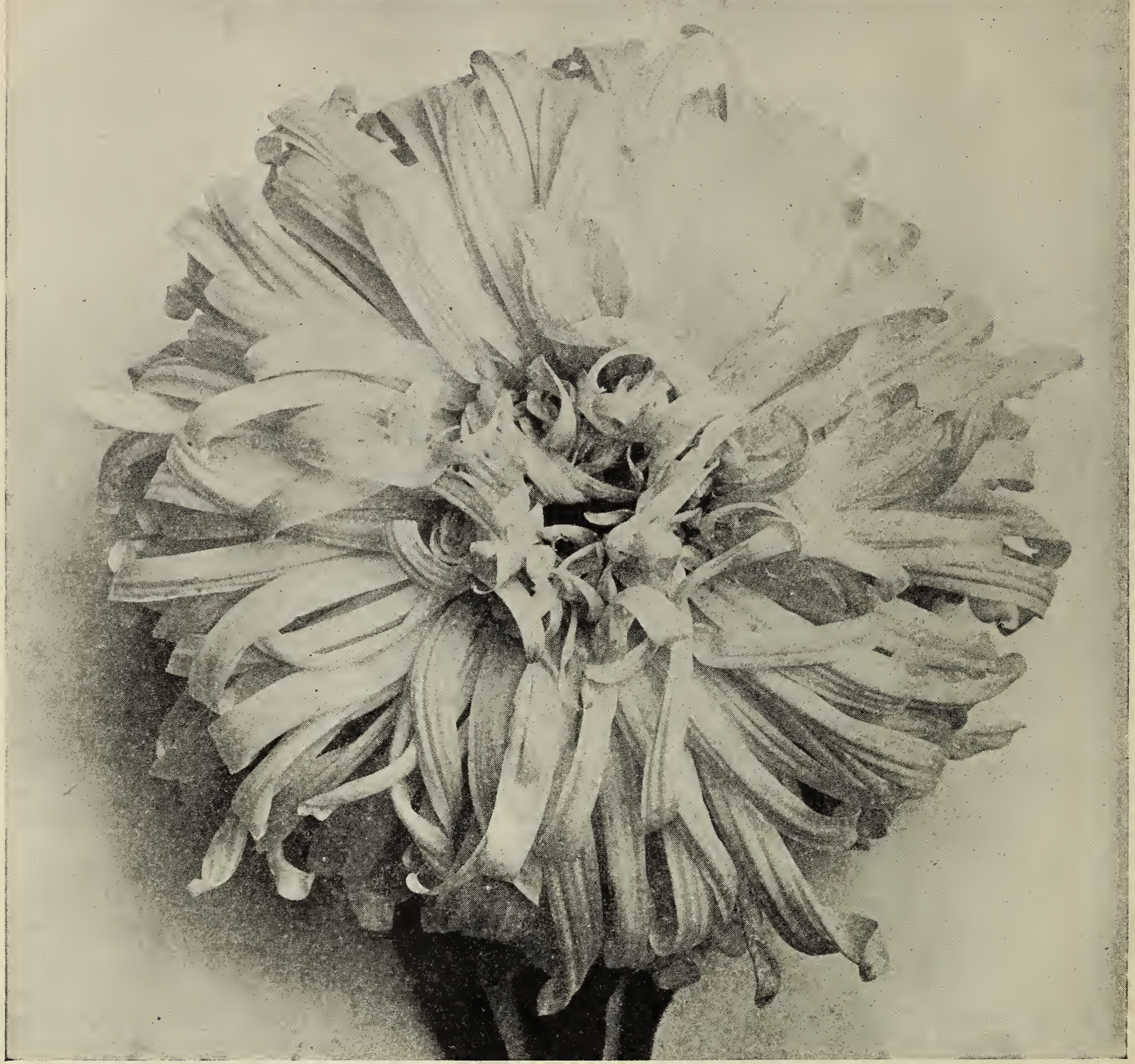

A Bloom of Our New California Giant Aster, Curled and Interlaced Type

\section{Howard \& Smith's New California Giant Non-lateral-branching Aster}

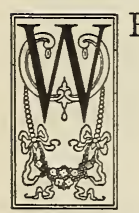

E PARTICULARLY direct your attention to this magnificent strain of Asters which we introduced a few seasons ago and which we have brought, by careful roguing and selection, to a higher state of perfection than ever. These Asters, in their present form, are second to none in the world today. They are a true non-lateral branching strain, each flower being borne at the terminal of a long stout stem 18 to 24 inches in length, with no lateral growths manifesting themselves in their entire length. The tedious method of disbudding in order to obtain size is entirely done away with; the non-lateral branching character of the stems diverts the entire sap flow to the single flower at the terminal which accounts for the remarkable size the flowers attain.

Another feature of this strain is their extended period of bloom, the plants remaining in flower much longer than any ather class of Asters which we know of at the present time. Hundreds of voluntary reports have been received in commendation of their quality. We are certain you cannot find better. 


\section{Aster}

\section{H \& S California Giant Curled and Interlaced Type}

CALIFORNIA GIANT CURLED \& INTERLACED PURE WHITE. This Aster is the result of several years work, to complete the color series of our giant strain. We had all colors excepting white and the addition of this superb variety completes the color series in a strain of Asters which is second to none in the world today. The huge fluffy blossoms resemble Chrysanthemums more than Asters, the plants have the same non-lateral branching stem characteristic of others of this race.

Per packet, 25c.

CALIFORNIA GIANT CURLED \& INTERLACED PEACH BLOSSOM. A magnificent Aster with immense blossoms, the petals being curled and twisted, after the most ultra refined Comet type. Flowers are borne on long stems strictly non-lateral branching in character. The color is a superb shade of peach blossom overlaying a white ground. A gem for cut flower purposes.

Per packet, 25c.

CALIFORNIA GIANT CURLED \& INTERLACED ROSE. The blossoms of this variety are of enormous size, frequently attaining a diameter of 6 inches or over. The color is a lovely uniform shade of dark rich rose. A simply magnificent variety. Per packet, 25c.

CALIFORNIA GIANT CURLED \& INTERLACED LIGHT BLUE. A clear lovely shade of pure azure blue. Flowers of great depth. Petals beautifully curled and interlaced. An exquisite color.

Per packet, 25c.

CALIFORNIA GIANT CURLED \& INTERLACED RICH PURPLE. A fine companion to the foregoing; has the same immense size and elegant flower formation as the preceding varieties. Well grown plants of this Aster when fully developed, reach a height of $31 / 2$ feet. The color is a rich shade of bluish purple. Very fine.

Per packet, 25c.

SPECIAL OFFER: One packet of each of the above superb Giant Asters for

$\$ 1.00$.

H. \& S. California Giant Curled \& Interlaced AstersMixed-all colors. An equally balanced mixture of the foregoing colors.

Per packet, 25c.

\section{Aster}

\section{H \& S California Giant Paeony Flowered}

This class is of the same non-lateral branching habit as those of the curled and interlaced type noted above, but the flowers are more formal in their petal arrangement. The blossoms are more or less irregularly incurved. The blossoms do not attain the size of our curled and interlaced type, but will average on well grown plants 4 to $4 \frac{1}{2}$ inches in diameter. We offer them in two beautiful colors.

CALIFORNIA G IAN T PAEONY FLOWERED PEACH BLOSSOM. A superb Aster with the same relative color value as that to be noted in the giant peach blossom of the curled and interlaced section. Stems 18 to 24 inches long. A very fine variety for cut flower purposes. A splendid keeper when cut. Per packet, 25c.

CALIFORNIA GIANT PAEONY FLOWERED LIGHT BLUE. A lovely shade of pure azure blue of even tone. A splendid companion to the foregoing, with blossoms of equivalent size and quality. Per packet, 25c.

\section{H \& S Improved Camellia Flowered Balsam}

A superb strain of this popular old-fashioned favorite. The plants bear dense masses of large Camellia-shaped flowers of perfect form and splendid stems. The colors range from pure white through the various shades of rose, crimson, salmon, etc. A splendid annual for Summer bedding, which requires plenty of water and a soil which has been heavily manured. All colors mixed.

Per packet, 15c.

\section{Foliage or Bedding Beet}

In England and on the Continent various ornamental varieties of beets are largely grown and are one of the most attractive of Summer bedding plants. There is nothing more showy than their brilliant and glossy varicolored foliage.

BEET CHILIAN. Deep crimson. Height, 24 inches. Per packet, 15 c.

\section{Begonia \\ CHRISTMAS CHEER}

A magnificent novelty in the everblooming or semperflorens section of hardy bedding Begonia. This splendid variety bears flowers of enormous size attaining a diameter of some 2 inches. The plants are literally smothered with bloom throughout the entire season. The color is charmingly fresh and bright, being a distinct shade of rich cherry crimson. Begonias of this class are particularly adapted for bedding purposes. They are quite hardy and will grow in either full sun or partial shade. This Begonia represents one of the greatest advances made in the dwarf ever-blooming bedding Begonia to date. Per packet, 25c.

\section{Calendula-Pot Marigold}

It has only been since the introduction of splendid improved types of these old-fashioned Marigolds that their value began to be appreciated. They thrive well in any good garden soil, and will stand several degrees of frost without injury. Our selection of these is exceedingly fine. The stems are long and flowers large and quite double. Fine for cutting.

BALL'S GOLDEN. A very fine type of Calendula, differing from our Orange King in that the flowers are lighter in color with somewhat longer stems. This Calendula is of special value for cutting purposes. Seeds may be sown during the Autumn for Winter and early Spring blooming or in the early Spring for Summer blooming. The blossoms are of very large size, very double, with elegantly arranged petals. Per packet, 15c. 


\section{Calendula-Continued}

H. \& S. ORANGE KING. One of the largest and deepest colored selections of Calendulas ever offered. The color is a vivid shade of dark rich golden orange. There is a richness and glow to the color of the flowers under full sunlight which might be likened to that of burnished gold. The flowers in our strain are fully double with the petals beautifully fimbriated at the edges. We can recommend this selection of Calendulas as being one of the finest extant. Nothing more valuable in California for Winter blooming than Calendulas and nothing of finer quality than this strain.

Per packet, $10 \mathrm{c}$.

\section{H. \& S. PRIZE LEMON} QUEEN. A fine companion to our Orange King. The blossoms are very large, quite double and of a uniform shade of rich lemon yellow. Extra choice.

Per packet, $10 \mathrm{c}$.

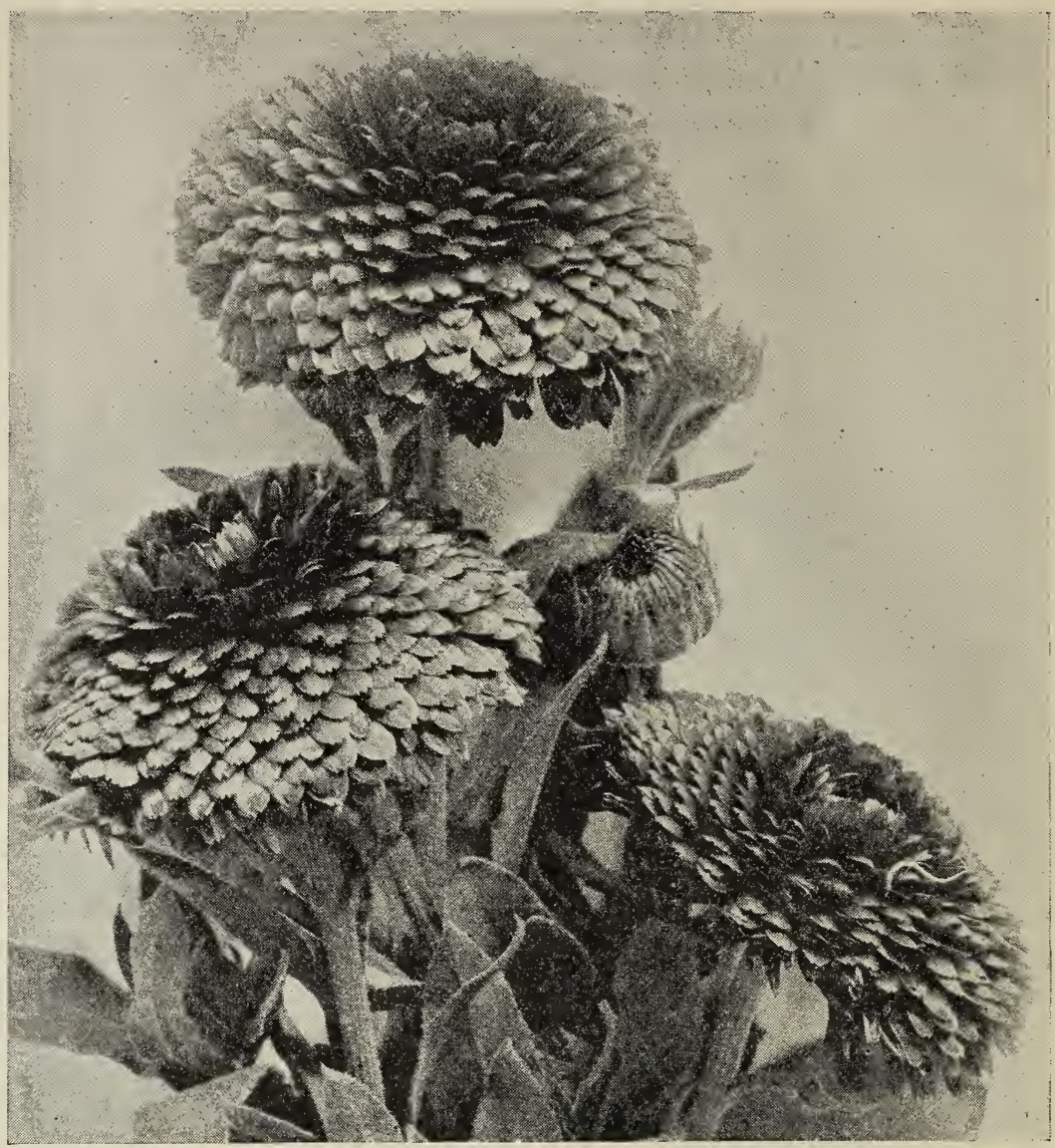

\section{Calliopsis}

Showy and beautiful free flowering annuals, of the easiest possible cultivation. They do well in any sunny position and are splendid for massing or for cut purposes.

DRUMMONDI, GOLDEN WAVE. Rich orange yellow with brown eye. Height, 18 inches. Per packet, 10c.

CRIMSON KING. Velvety crimson, 9 inches high.

Per packet, 10c.

ANNUAL MIXED. A superb mixture, including all shades of colors and combinations of colors, in brown, golden yellow, etc.

Per packet, 10c.

\section{Campanula}

CARPATICA WHITE. One of the dantiest of the family. An exquisite bell flower of low prostrate growth, bearing a wonderful profusion of pure white flowers in early Spring. Valuable for rockeries or as a basket plant.

Per packet, 15 c.

CARPATICA BLUE. Identical with the white form and quite as free flowering, bearing enormous quantities of beautiful bell-shaped, deep blue flowers.

\section{Candytuft}

Per packet, 15c.

GIANT HYACINTH FLOWERED WHITE. The largest and best white grown. Our selection of this is extra choice.

CARMINE. An attractive shade of carmine.

Per packet, 15c.

Per packet, 10c.

Calendula $-\mathrm{H}$ \& S Orange King

FLESH PINK. A pretty shade of pale pink.

Per packet, 10c.

LILAC. Clear mauve or lilac blooms. Per packet, 10c.

\section{Celosia Plumosa}

Giant Plumed Cockscomb

\section{Two New Handsome Dwarf Varieties}

H. \& S. PRIZE DWARF CRIMSON. A fine companion to the following, being an exact replica in every respect but color-the latter rich glowing scarlet crimson. The spikes are beautifully formed surmounting a neat compact plant. Excellent for Summer bedding.

Per packet, 25c.

H. \& S. PRIZE DWARF GOLDEN YELLOW. A splendid deep golden yellow variety of this useful Summer bedding plant. The plants attain a height of some 18 inches forming bushy specimens covered with plumy spikes of bloom of a bright golden yellow color. A grand Celosia for bedding purposes, coming almost entirely true from seed.

Per packet, 25c.

HOWARD \& SMITH PRIZE TALL MIXED. A grand selection of feathered Cockscomb with massive plumes and excellent compact habit. We have been several seasons improving this strain and believe today it is equal or superior to any other strain on the market. The colors range from yellow through the intervening shades of rose, carmine, crimson and bronze. Per packet, 25c. 


\section{Celosia Childsii}

A splendid subject in annual flowers. Belongs to the Cockscomb family and differs from the ordinary Cockscomb or pyramidal flowered Celosia in that the inflores cence occurs in a ball-shaped form. The color is dark crimson. Heads of bloom are 4 or 5 inches in diameter and freely produced on stout branching compact plants.

Per packet, 15 c.

\section{Centaurea Imperialis-Giant Sweet Sultan}

A highly improved strain of Centaureas, with flowers of magnificent size and a wide range of colors. Being good keepers in water, they are much prized as cut flowers. The distinctive character and informal shape of the blossoms add a grace and charm distinct from all other cultivated plants. Height, 30 inches.

AMARANTH RED. A distinct new shade. Very fine. Per packet, 15c.

BRILLIANT ROSE. Large beautifully formed flowers. Soft rose pink.

Per packet, 15 c.

LAVENDER. A lovely shade of pure lavender blue.

Per packet, 15 c.

PURPLE. Bright imperial purple. Per packet, 15c. WHITE. A chaste pure white flower. Per packet, 15c. SUAVEOLENS (Yellow Sweet Sultan). Like Centaurea Imperialis in general formation of bloom, but with flowers of a lovely, pure, rich yellow. Per packet, $15 \mathrm{c}$.

\section{Centaurea Cyanus-Cornflower}

An old well-known favorite, greatly prized for cutting purposes. We particularly direct your attention to the following three double forms which are very fine indeed. The seed we offer will produce about 70 per cent of perfectly double blossoms.

Candytuft

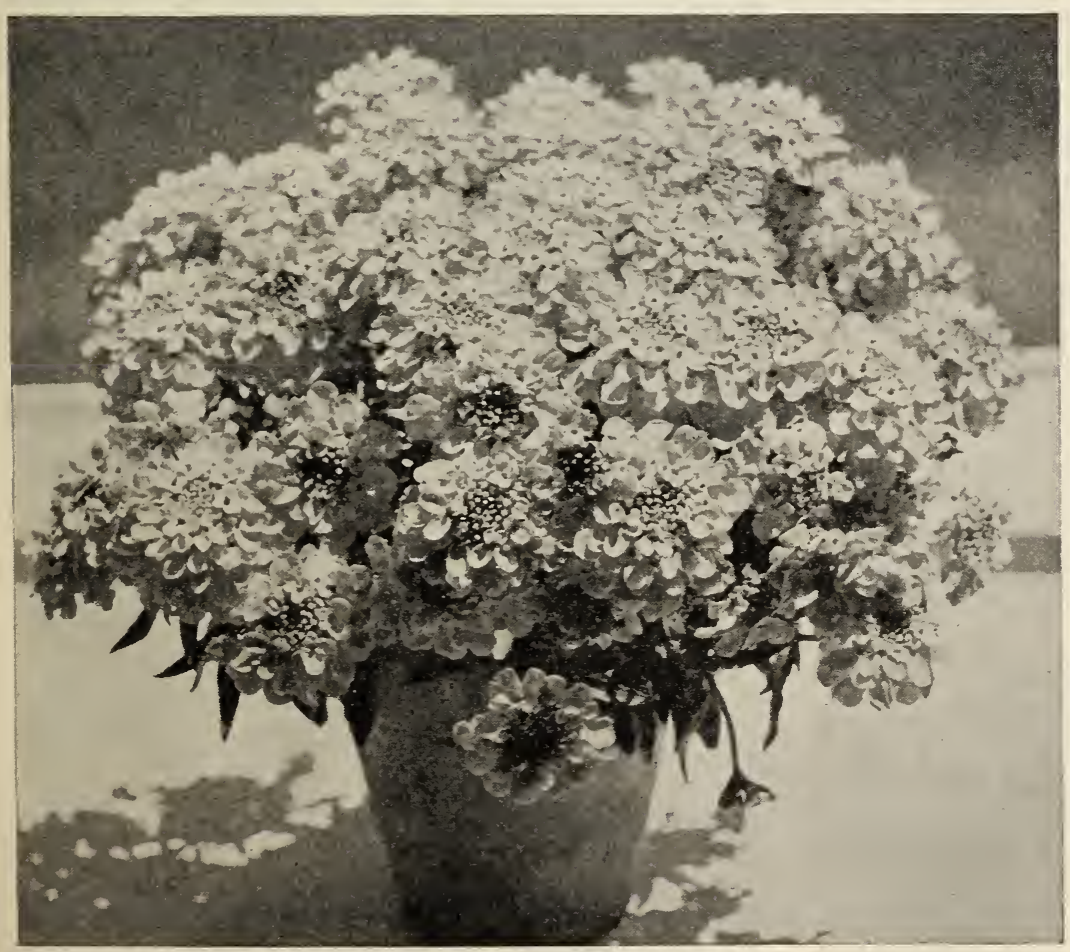

DOUBLE BLUE. Bright corn flower blue.

Per packet, 15 c.

DOUBLE ROSE. Rich silvery rose. Per packet, $\mathbf{1 5 c}$.

SILVER QUEEN. The finest double white introduced to date, with large splendidly formed pure white flowers.

\section{ALL COLORS MIXED.}

\section{Centaurea}

CANDIDISSIMA (Dusty Miller). One of the handsomest of all dwarf bedding plants. Our selection of this particular variety is one of unsurpassed quality. The foliage is a uniform beautiful silvery white, and the plants are as even in growth as though they were sheared. Height, 12 inches. Highly recommended for bedding or for edging purposes.

Per packet, 15 c.

\section{Chrysanthemums-Annual Varieties}

These are very valuable for Summer blooming and in warm sections of the country bloom profusely during early Spring and Winter. They produce large quantities of flowers which are eminently adapted for cut flower purposes; their keeping qualities being unexcelled. They are of easy culture and although a simple annual, are among the most beautiful.

\section{Single Varieties}

JOHN BRIGHT. Brilliant golden yollow. Very fine. Per packet, 15 c.

MORNING STAR. Flowers of immense size. In color a lovely shade of soft primrose yellow. A grand variety for cutting purposes.

Per packet, 15 c.

NORTHERN STAR. Very large flowered. Ivory white zoned sulphur at the middle of the bloom. Per packet, 15c.

THE SULTAN. Rich wall-flower red with a yellow zone surrounding the central brown disc. Per packet, 15 c.

\section{Double Varieties}

DUNNETT'S DOUBLE WHITE. A splendid double pure white form of annual Chrysanthemum with large wellformed blossoms. Ideal for cut flowers.

Per packet, 15 c.

DOUBLE RED. A fine companion to the above with flowers of similar shape and size, in a distinct shade of brownish red.

Per packet, 15c.

DOUBLE FRINGED HYBRIDS. This strain is very fine indeed and includes all colors from light to dark. The petals are beautifully fimbriated and notched, giving the flower a fringed appearance. Many beautiful art shades are included in this mixture.

Per packet, 15c.

INODORUM SNOWBALL. A handsome new annual Chrysanthemum, bearing quantities of double snow white flowers, 2 inches across. Foliage is fern-like in appearance, being deeply laciniated and offering a beautiful foil to the well-poised flowers. Highly recommended as a cut flower, especially where used for mixed bouquets.

Per packet, 15 c. 


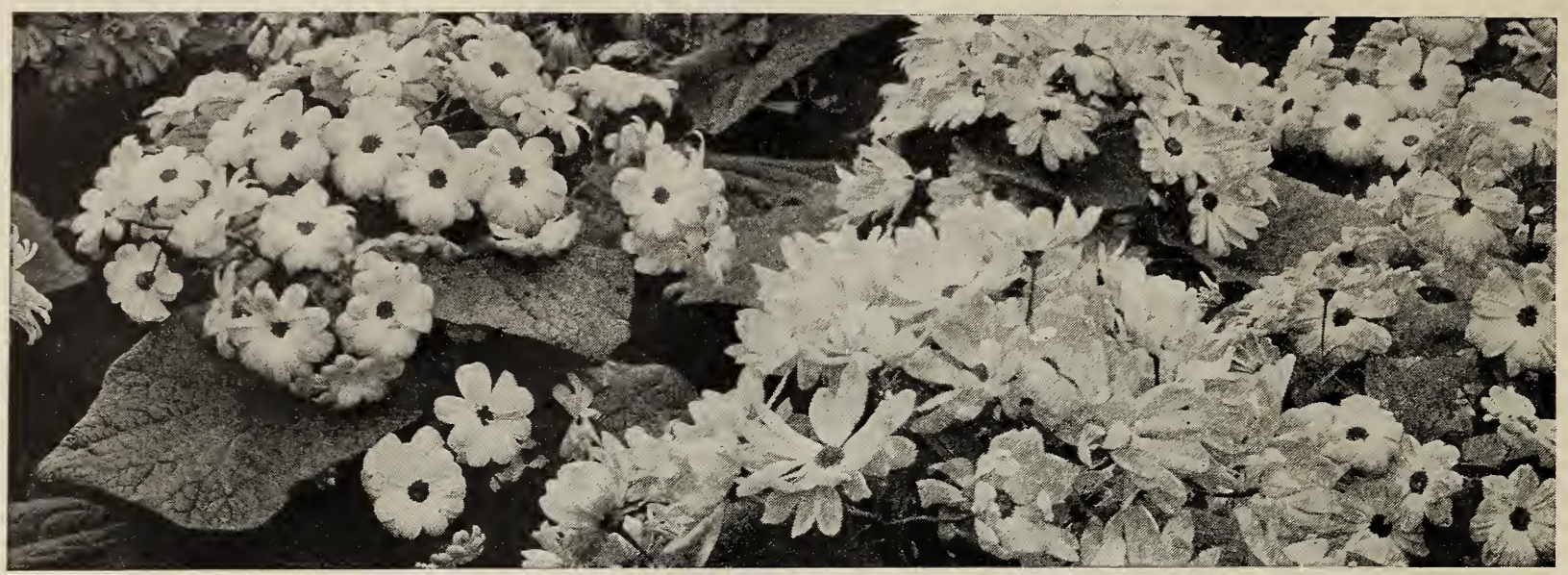

Cinerarias of Our Prize Glant Flowered Strain as Grown for Seed at Our Montebello Nurseries

Our strain of giant flowering Cinerarias is generally recognized as one of the finest in America. The plants are compact in their habit, the foliage is large and bold and is surmounted by trusses of glorious size and substance. Blossoms 4 to $4 \frac{1}{2}$ inches in diameter are quite common. The range of colors contained in the strain is un excelled, running from purest white to darkest crimson, through all the intervening shades of purple, blue, lavender, indigo, rose, etc., with many handsome bi-colored flowers.

The demand for this seed has become so great and its quality so universally recognized that our cultures of plants in pots for the current sea son will approximate some 15,000 plants. No more glorious sight can be imagined than these Cinerarias when in full bloom. They usually reach the height of perfection about April 15th, at which time a visit to our nurseries to see them is well worth while.

Per packet, 50c.

\section{Clarkia}

An old-fashioned annual which has been greatly improved during recent years. The long slender racemes of flowers are excellent for cutting purposes. They las: well in water and give a wonderful show of color in the garden. The following are among the best.

ALBA. Pure white. Very double flowers.

Per packet, 15c.

ORANGE KING. Bright orange scarlet flowers. Large and double.

Per packet, 15=

QUEEN MARY. A very double and free flowering Clarkia. Rose carmine in color. Very bright.

Per packet, 15c.

ROSEA. Bright rose. A clean telling color.

Per packet, $\mathbf{1 5 c}$.

VESUVIUS. Flower large and double. Bright scarlet in color.

Mixed, all colors.

\section{Cobaea Scandens}

A elegant vine of very rapid growth, which can be easily raised and flowered from seed the same season. The flowers are quite large, about 3 inches across, and in shape not unlike those of the Canterbury Bells. It has handsome bronzy foliage and is remarkable for its rapid growth, which makes it particularly adaptable for quick work in covering fences, pergolas, etc. Seed should be sown in early Spring for flowering the following Summer. Highly recommended as a shade producing vine. Per packet, 15c.

\section{Cockscomb}

An old-fashioned favorite, much prized for bedding. Is equally valuable for growing in pots for interior decoration. The seed we offer has been saved exclusively from large, well-formed combs.

DWARF EMPRESS. Large and perfect combs. Deep crimson color. Very choice. Height, 9 inches.

\section{Columbines-H. \& S. New Giant Flowering}

A grand strain of giant flowering long spurred Columbines in a color series of matchless beauty. Columbines are splendid as cut flowers or for the production of masses of color in the garden. We have made a series of selections to color, and although not entirely fixed, a very high percentage will come true.

BLUE. A splendid selection of all shades from light to dark blue. Flowers are long spurred and of large size.

Per packet, 25c.

PINK. Contains the various tones from light pink to darkest rose. Very choice.

Per packet, 25c.

SCARLET. We are able to offer seed for the first time of this splendid selection of scarlet colored Columbines. Blossoms range through all the colors of light scarlet, dark scarlet and crimson. A grand strain which comes nearly true from seed.

Per packet, 25c.

MIXED. Including all shades from pure white to pink, rose, red, yellow, crimson, blue and various bi-colored flowers of superb quality and form. Per packet, 25c. 


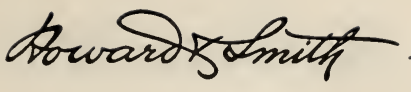

\section{Coreopsis Grandiflora}

A hardy perennial bearing masses of golden yellow flowers throughout the major portion of the year. Splendid for cutting. Height, 30 inches. Per packet, 15c.

\section{Cosmos}

Favorite Summer and Autumn flowering annuals, producing an endless succession of flowers over an extended period. The strains we offer are the finest procurable, with blooms of exceedingly large size, and a very fine selection of colors. We call your special attention to the new double types.

K L O N D Y K E. Handsome, large, orange-colored blooms. Should be planted early, as it invariably flowers late in Autumn.

Per packet, 15 c.

LADY LENOX. Bright rose. One of the new mammoth types.

Per packet, 15c.

LADY LENOX WHITE. Large, pure white.

Per packet, 15c.

MAMMOTH, EARLY FLOWERED. Crimson, rose, white and mixed.

Per packet, $\mathbf{1 5 c}$.

NEW DOUBLE MIXED. Beautifully formed blooms, having a cushion-like center of short florets, not unlike in many respects the Anemone flowered Chrysanthemums. The plants are very free blooming and will produce about 70 to 80 per cent of double flowers. All colors mixed, including white, crimson rose, pink etc.

Per packet, 25c.

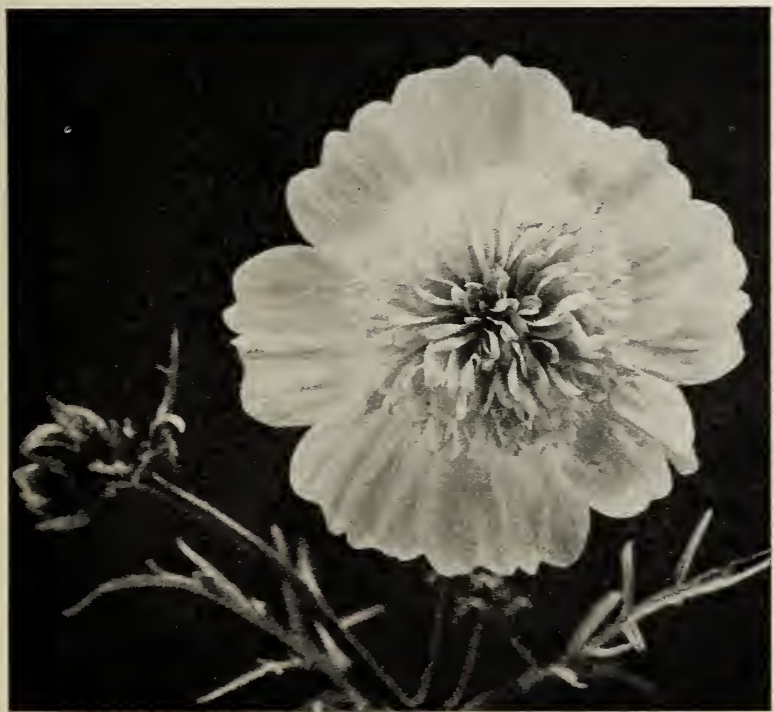

Double Cosmos

\section{Dahlias}

Although it is not commonly known, Dahlias can be easily raised from seed and flowered the same season during which the seed is sown. During the past year we harvested a small quantity of seed from some of our very finest shy seeding named varieties. Seed may be sown at any time during February, March or April, and a bountiful crop of bloom may be assured during September, October and November.

H. \& S. PRIZE MIXTURE. Some splendid varieties may be raised from a package of this seed. The seed has been saved from the very finest named varieties, including Cactus, Decorative and Paeony flowered types.

Per packet, 25c.

\section{New Giant Daisies}

BELLIS PERENNIS MONSTROSA. A highly improved strain of Daisies, remarkable for their immense foliage and extra large flowers. Blossoms attain a diameter on well-grown plants of 2 inches and over and come true from seed. The value of Daisies for Spring bedding is well-known and appreciated.

WHITE. A pure snowy white of very large size.

Per packet, 25c.

ROSE. A dainty shade of pure rose: Per packet, 25c.

RED. Gigantic flowered rich rosy red Daisy. Extra fine.

Per packet, 25c.

\section{Delphinium-Perennial Larkspur}

Shades of blue are exceedingly scarce in flowers, yet there is scarcely a shade which cannot be found in a good strain of choice perennial Larkspurs. Our seed of this particular strain is saved from a magnificent collection-one of absolutely unexcelled quality. A few of the shades to be noted in the mixture are sapphire, turquoise, gentian, sky blue, etc. As back row flowers in the herbaceous border they are well nigh indispensable. In English gardens they are invariably the most conspicuous and highly prized amongst herbaceous plants.

Per packet, 25c.

BELLADONNA. A splendid variety of perennial Delphinium. The flowers are an exquisite shade of sky blue, and are borne on long, wiry stems, which makes them particularly valuable for cutting purposes. This variety blooms without intermission from early Spring until late Autumn, and the clumps last from season to season, as it is a true perennial.

Per packet, 25c.

BLUE BUTTERFLY A handsome dwarf biennial variety which attains a height of some 18 inches. The flowers are a rich bright blue in color; grows easily from seed and blooms within a comparatively short space of time after sowing.

Per packet, 15c.

AZURE FAIRY. A dainty dwarf biennial Delphinium; a fine companion to Blue Butterfly. Flowers are a distinct shade of azure blue. The plants attain a height of about one foot and blossom from early Spring until late Autumn.

Per packet, 25c.

\section{Dianthus-Annual Pink}

Although usually treated as annuals, these Dianthus are really biennial in character and will flower again the second year if not killed during the Winter.

SUPERBISSIMA. A splendid strain of annual pinks, with deeply fringed and ruffled blossoms. Flowers exceedingly large, and with a wide assortment of colors. Undoubtedly the finest strain of single Dianthus in existence. 


\section{Diascea Barbarae}

A low-growing biennial plant from South Africa, bearing innumerable quantities of small salmon-colored blossoms. The plants attain a height of some 12 inches and are literally smothered with their dainty salmoncolored flowers. A fine subject for beds or borders.

Per packet, 25c.

\section{Digitalis-Foxgloves}

THE SHIRLEY. A remarkable improvement in this old-fashioned plant may be found in this strain. Thev are the result of many years of careful reselection and are so much in advance of the older types, that there is practically no comparison in quality. The stems attain a height of 5 to 7 feet, that portion covered with flowers often reaching the remarkable length of 4 feet. The blossoms are of enormous size, ranging in color from pure white to deepest rose, while others are beautifully blotched and spotted dark maroon, crimson and chocolate.

Per packet, 25c.

GLOXINIA FLOWERED WHITE. Per packet, 15c. GLOXINIA FLOWERED ROSE. A chocolate. All colors mixed.

GLOXINIA FLOWERED PURPLE. deep purple. Per packet, 15c.

GLOXINIA FLOWERED. Mixed colors. Giant flowers, spotted and shaped like Gloxinias. Per packet, 15c.

\section{Eschscholtzia-California Poppy}

GIANT ORANGE SCARLET. A remarkable selection and without question one of the handsomest of all types of California Poppies. Blooms exceedingly large. In color a luminous shade of rich orange scarlet.

Per packet, 25c.

GOLDEN WEST. Enormous flowers. Deep rich yellow with an intense orange-colored center. Per packet, 10c.

CARMINE KING. Flowers a distinct shade of bright carmine rose. Extra good.

Per packet, 10c.

WHITE. A good selection, creamy white flowers.

Per packet, 10c.

\section{Dimorphotheca}

A comparatively new annual from South Africa, producing an abunclance of Daisy-like flowers, some $21 / 2$ inches across. Blossoms within a few weeks after sowing. Height, 12 inches.

AURANTIACA. Rich glittering orange, with brownish disc at center of bloom.

Per packet, 10c.

AURANTIACA HYBRIDS. Extra choice. A new series of hybrids offering a unique assortment of shades extending from the purest white through tints of orange, yellow, red, salmon.

Per packet, $15 c$.

Per packet, 25c.

A rich shade of

\section{Gaillardia}

LORENZIANA. Annual. Large double flowers in a splendid assortment of colors.

Per packet, $\mathbf{1 0 c}$.

H. \& S. PRIZE MIXED. A magnificent new strain of perennial Gaillardias, bearing flowers of enormous size in a wide range of beautifully marked flowers. The blossoms are single or semi-double. The edges of the petals are beautifully fringed or ruffled after the manner of the flowers to be noted in our named variety "Portola." The strain contains pure yellow selfs, bright rich orange, others beautifully zoned with orange and yellow, bronze grounds tipped yellow, etc. They are of remarkable size, attaining in many instances a diameter of 5 inches or over. Per pk. 25c.

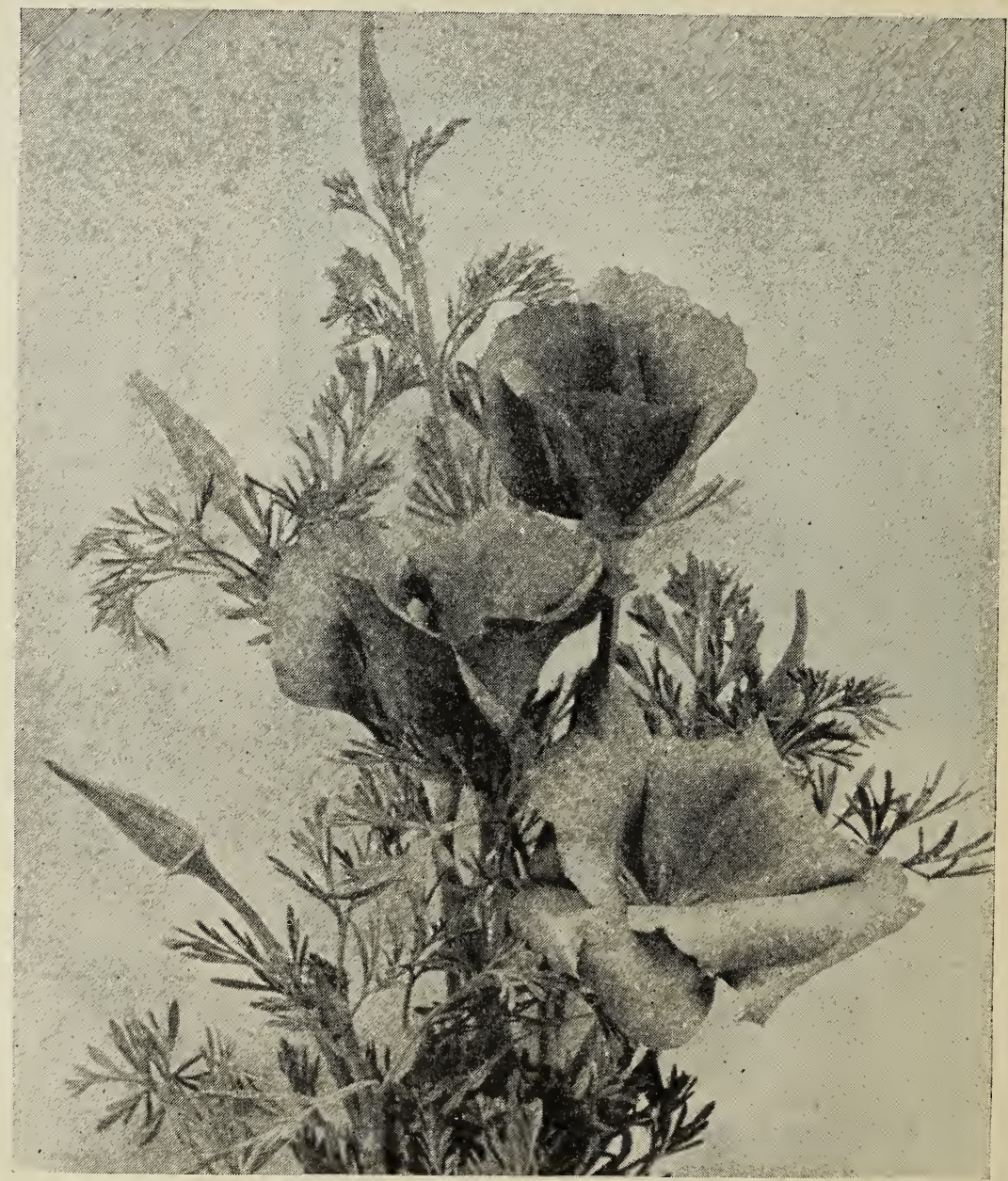

Eschscholtzia-Giant Orange Scarlet 


\section{Gerbera-Transvaal Daisies}

We were fortunate during the past season in being able to secure a fine lot of seed of these beautiful Transvaal Daisies. The strain includes all colors from pure white to darkest crimson, with all of the intervening shades of orange, yellow, pink, salmon, etc. These Gerberas are easily raised from seed and blossom the first season after sowing. As cut flowers they are unexcelled as they last over a week in water. An extra choice mixture, including all colors.

Per packet, $\mathbf{5 0 c}$.

\section{Geum}

"MRS BRADSHAW." A recent introduction and one of the most meritorious additions to perennial plants in a long time. The flowers are large, quite double and of the brightest scarlet. Invaluable for cut flower purposes. Height, 18 inches.

Per packet, 25c.

LADY STRATHEDEN. A splendid double Geum with rich golden yellow flowers, similar in form and size to the variety Mrs. Bradshaw. A splendid variety.

Per packet, 25c.

\section{Godetias}

A showy class of annuals with large variously colored flowers, producing a constant blaze of color in the garden over a long period of time. Nothing is more conspicuous than a clump of well-grown Godetias.

DOUBLE CRIMSON. A splendid double flower rich crimson in color. Per packet, 10c.

DUCHESS OF ALBANY. Elegant silvery white.

Per packet, $10 \mathrm{c}$.

GLORIOSA. Deep blood red. A compact growing bedding variety. Very fine. Per packet, 10c.

LADY SATIN ROSE. Rich rose color. A fine companion to Gloriosa.

Per packet, $10 \mathrm{c}$.

WHITNEYI COMPACTA. Splendid deep carmine rose of brilliant effect.

\section{Gypsophila}

Although the flowers of Gypsophila in themselves are somewhat insignificant in character, they tend to give a beautiful and feathery effect to flower arrangements of all kinds. The blossoms are produced in panicles. The individual flowers are quite small, but are produced in great abundance. As a decorative accompaniment to sweet peas, carnations, etc., they are unequalled.

ELEGANS GRANDIFLORA (Annual). Large flowered, pure white form. Can be flowered from seed within a few weeks after sowing.

Per packet, $10 c$.

PANICULATA. Hardy perennial variety. Smaller flowers than grandiflora, but equally valuable for cut flower purposes.

\section{Helichrysum-Straw Flower}

A well-known class of everlasting flowers which are prized not only for their value as plants in the garden, but for their use as cut flowers for Winter decorative purposes. The flowers after being cut retain their color and form without fading. We offer this season a very fine strain of the Monstrosum type. The flowers are of gigantic size, the colors rich and varied.

MONSTROSUM. Very large flowered, pure white.

Per packet, 15c.
MONSTROSUM YELLOW. A handsome shade of golden yellow. $\quad$ Per packet, 15c.

MONSTROSUM SALMON RED. A unique shade of rich salmon red.

MONSTROSUM ROSE. Deep bright rose.

Per packet, $\mathbf{1 5 c}$.

Per packet, 15c.

MONSTROSUM PURPLE. A distinct shade of dark purple. Per packet, 15 c.

MONSTROSUM MIXED. All colors. Per packet, 15c.

\section{Heliopsis Scabra Zinniaflora}

A few seasons ago there appeared in France some new hybrids of Heliopsis, which were sent out under the preceding name, the flowers being double or semidouble, similar to Zinnias in general shape and contour and a rich golden yellow color. These have since proven to be of splendid value for cut flower purposes. The plants attain a height of some two or three feet and blossom profusely throughout the Summer and Autumn months. They are easily raised from seed and will, we feel assured, prove a welcome addition to any garden. The plants are of perennial duration. We can thoroughly recommend them to our customers as one of the most meritorious plants of recent introduction. Per packet, $\mathbf{1 5 c}$.

\section{Heliotrope}

The seed we offer of this popular favorite has been carefully saved from the very finest named varieties. It is nothing unusual for the plants to bear heads fully 12 inches in diameter, produced on compact growing plants. Seed sown in early Spring will produce full grown plants for July blooming. They can be lifted in the Autumn and used as pot plants during Winter. Height 15 to 18 inches.

LEUR d'OPALE. Giant lavender blue. Per packet, 25c.

\section{Hollyhock Double Exquisite}

A new strain of Hollyhock which will prove a delight to all of those who enjoy this old-fashioned flower in an entirely new form. Blossoms are beautifully fringed and frilled or deecly dentate and the colors are charmingly fresh and bright. The flowers are large and beautifully placed on tall stately spikes. Much of the stiff effect to be noted in the older types is entirely lacking in this truly exquisite new strain. We cannot recommend them too highly to our customers.

Per packet, 25c.

\section{Hollyhock}

A superb strain of the finest types of $d$ ruble Hollyhocks extant, in clean, decided colors. A sowing made in early Spring will flower with good cultivation during the ensuing Summer and Autumn. There is nothing more attractive as back row plants than Hollyhocks. 


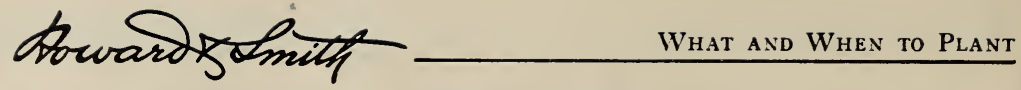

DOUBLE ROSE. An exquisite shade of pure rose pink. Per packet, 15 c.

FAUST. Rich dark maroon.

Per packet, $\mathbf{1 5 c}$.

NEWPORT PINK. Pure glistening rose pink.

Per packet, $\mathbf{1 5 c}$.

WHITE. Pure snowy white, very double.

Per packet, $\mathbf{1 5}$ c.

WHITE SHADING TO PINK.

Per packet, 15c.

YELLOW. Bright golden yellow.

Per packet, 15 c.

DOUBLE MIXED. All colors.

Per packet, 15c.

SINGLE MIXED. Alovely strain of single Hollyhocks in all colors ranging from pure white to pink, crimson, rose, yellow, etc.

Per packet, $\mathbf{1 5 c}$.

\section{Hunnemannia-Mexican Poppy}

FUMARIAEFOLIA. A native Mexican Poppy of exceeding grace and beauty. The flowers are a beautiful deep lemon yellow and are produced in wonderful profusion. One of the best of all for cut flowers purposes.

\section{Larkspur \\ STOCK FLOWERED}

Per packet, 10c.

The annual Delphiniums or Larkspurs, as they are commonly called, are quite hardy and produce over a long
period splendid spikes of bloom of ex-

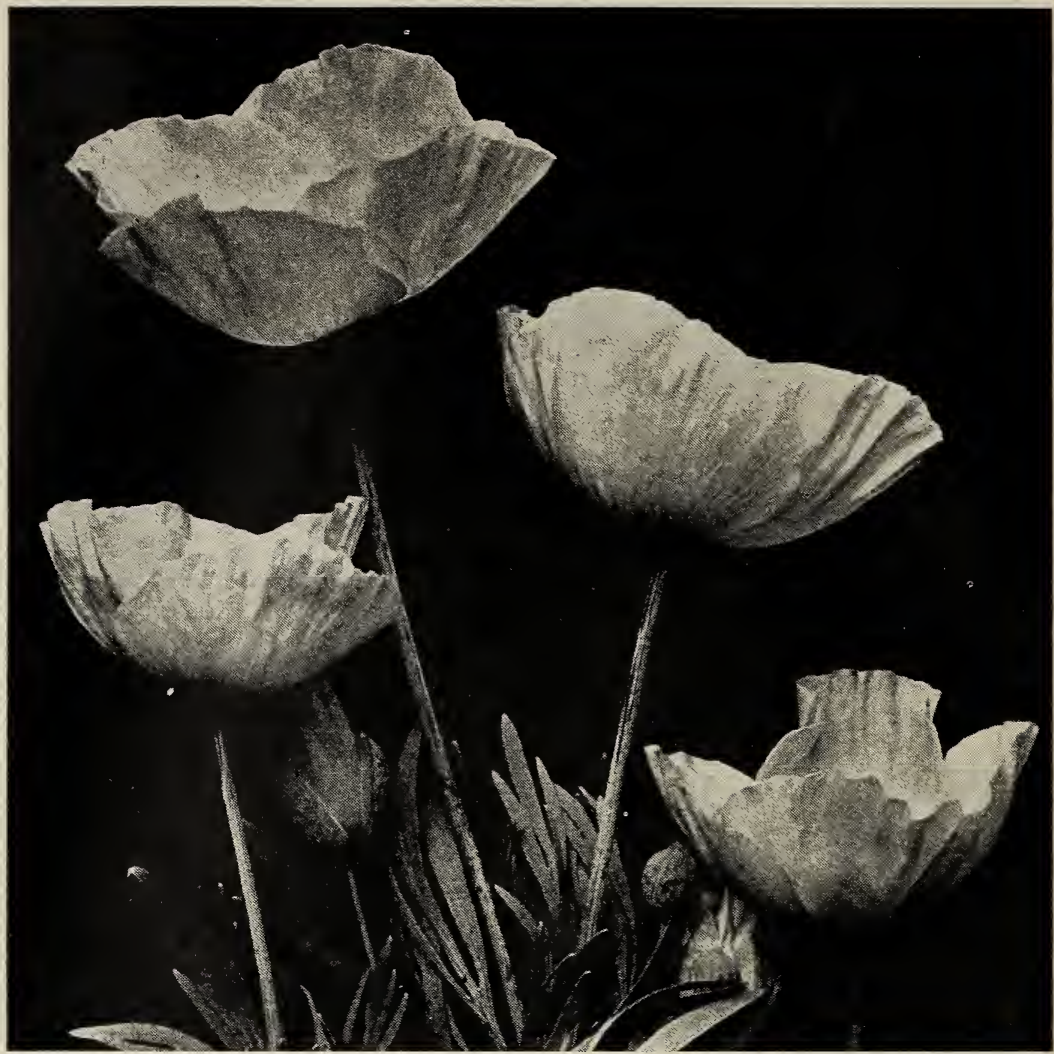
ceedingly graceful and attractive appearance. The taller varieties are suitable for mass effects in borders, while the dwarf strains are splendid as bedding plants. A bed of the various shades lends a charming effect to any garden.

\section{BRIGHT ROSE.}

DARK BLUE.

LILAC.

LUSTROUS CARMINE.

ROSY SCARLET.

SHELL PINK.

WHITE.

MIXED. All colors.
Per packet, 15c. Per packet, 15c. Per packet, 15c. Per packet, 15c. Per packet, 15c. Per packet, 15c. Per packet, 15c. Per packet, 15 c.

\section{Lathyrus Latifolius EVERLASTING PEAS}

A charming class of hardy perennial climbing Peas. Of great value for covering arbors and trellisses. They begin to blossom in early Spring and continue right through the Summer. Valuable for cutting purposes and extremely decorative in their general effect as a climbing flowering plant.

PINK BEAUTY. Bears innumerable quantities of pure blush pink-colored flowers.

RED. Bright carmine red.

Per packet, $\mathbf{1 5 c}$.

Per packet, $\mathbf{1 5 c}$.

WHITE PEARL. A distinct improvement over all other white flowered forms. Snowy white in color. Extra fine for cutting purposes.

Per packet, 15 c.

Hunnemannla

\section{Linaria Marocana}

EXCELSA HYBRIDS. A splendid strain of dwarf Linarias containing a wonderful range of colors. The flowers are quite small, borne in dense masses on slender stems, making, when in full bloom, veritable masses of color. They are of exquisite effect when used in beds or borders.

Per packet, 15c.

\section{Linum}

GRANDIFLORUM RUBRUM. An elegant free flowering, hardy annual, easily raised from seed. Its brilliant scarlet flowers attract the attention at once. Height, 12 inches.

Per packet, 10c.

\section{Lobelia}

Highly desirable for edgings, ribbon bordering as well as for pot culture. The plants are easily raised from seed, and during the flowering period are covered with a sheet of bloom.

CRYSTAL PALACE GEM. Dark blue.

Per packet, 15c.

TENUOIR COMPACTA. A magnificent new bedding Lobelia of dwarf compact habit with very large individual flowers which completely cover the plant. In color bright blue with a distinct white eye at the center of the flower. One of the handsomest of all varieties for bedding purposes.

Per packet, 25c. 


\section{Marigold}

The various types of Marigold, including African and French varieties, are old favorite, free flowering annuals of easy culture. The African sorts produce double flowers 3 to 4 inches in diameter. The French types are of more compact growth with double flowers variously blotched and marked in shades of maroon, brown, yellow, etc. We particularly recommend our strain of tall African Marigolds, and believe they cannot be excelled.

GIANT AFRICAN ORANGE. Flowers of absolutely perfect form and large size. Color is an intense shade of golden orange wonderfully rich and effective. A superb selection of this favorite Summer flowering annual.

Per packet, 10c.

GIANT AFRICAN LEMON. Identical with the preceding, with handsome deep lemon yellow flowers. Both this and the Giant African Orange are eminently adapted for cutting purposes.

Per packet, 10c.

FRENCH GIANT GRANDIFLORA MIXED. A splendid selection of the striped Grandiflora class. Flowers vary in color through shades of brown, yellow, etc.

Per packet, $\mathbf{1 5 c}$.

GOLD STAR (French dwarf). A dwarf compact Marigold bearing masses of bright golden yellow flowers.

Per packet, 10c.

LEGION OF HONOR. A splendid dwarf Marigold belonging to the French class. The plants attain a height of some 9 to 12 inches. Flowers are beautifully marked with gold and brown and are produced in such

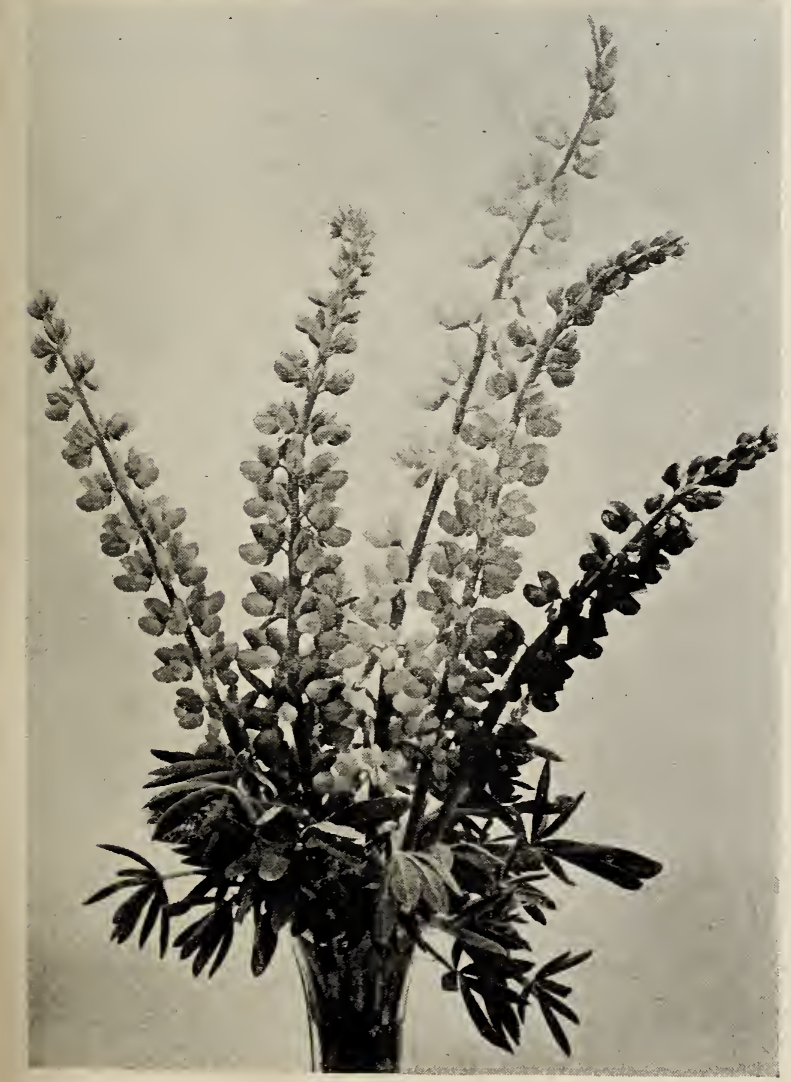

Lupin-Mixed Hybrids

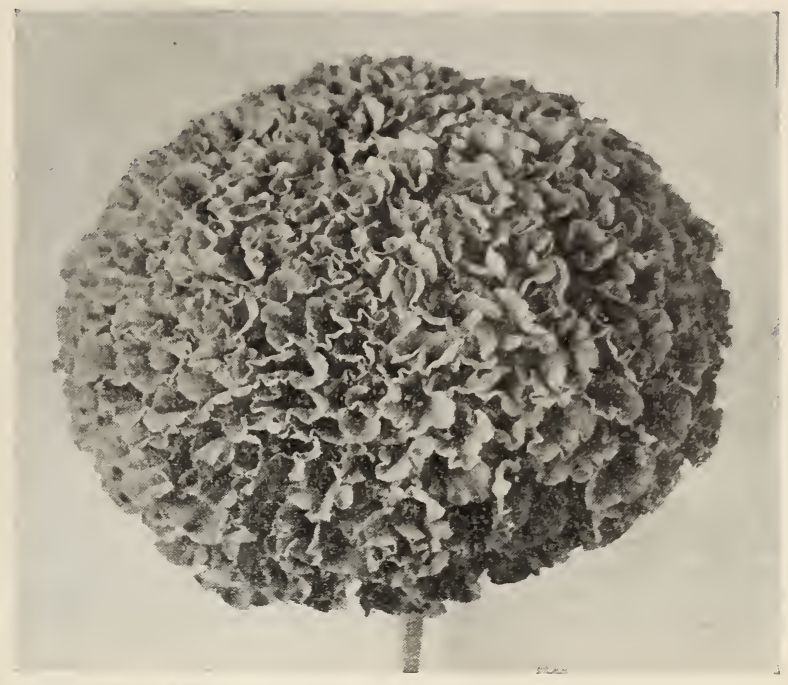

Marigold-Giant African Orange

quantities as to completely cover the plant. An ideal subject planted in solid mass effect or for borders, etc.

Per packet, 10c.

STAR OF INDIA (French dwarf). Handsomely striped dwarf Marigold suitable for bedding or edging purposes. Flowers deep crimson prettily striped with golden yellow.

Per packet, 10c.

\section{Mignonette}

A few plants of these scent the whole garden with their delicate fragrance. Sow in drills, as the seedlings do not transplant readily. Thin the seedlings when 1 or 2 inches high to 1 foot apart. Cover the seed one-eighth of an inch deep with finely sifted soil. Height, 12 inches.

GOLDEN QUEEN. A beautiful yellow.

Per packet, 15c.

GOLIATH. As the name implies, a very large flowered Mignonette. Strong compact habit with rich dark green foliage. The giant trusses have a reddish cast. The color is very brilliant, somewhat deeper than the ordinary Machet.

Per packet, 15c.

MACHET. Large flowers with a delicious odor.

Per packet, 10c.

\section{Myosotis-For-get-me-not}

Among the various flowers of early Spring there are few more appreciated than the various types of Forget-me-nots. All the colors are beautiful, from the pale blue of the Dissitiflora type to the deep blue Alpestris and the white and various rose-colored shades. Height, 10 inches.

DISSITIFLORA. A magnificent pale sky blue For.* get-me-not. Per packet, 15 c.

ALPESTRIS BLUE. A lovely shade of deepest blue. Per packet, 15 .

ALPESTRIS WHITE. A pure white. Per packet, 15c. ALPESTRIS ROSE. A handsome shade of light rose. Per packet, 15 c. 


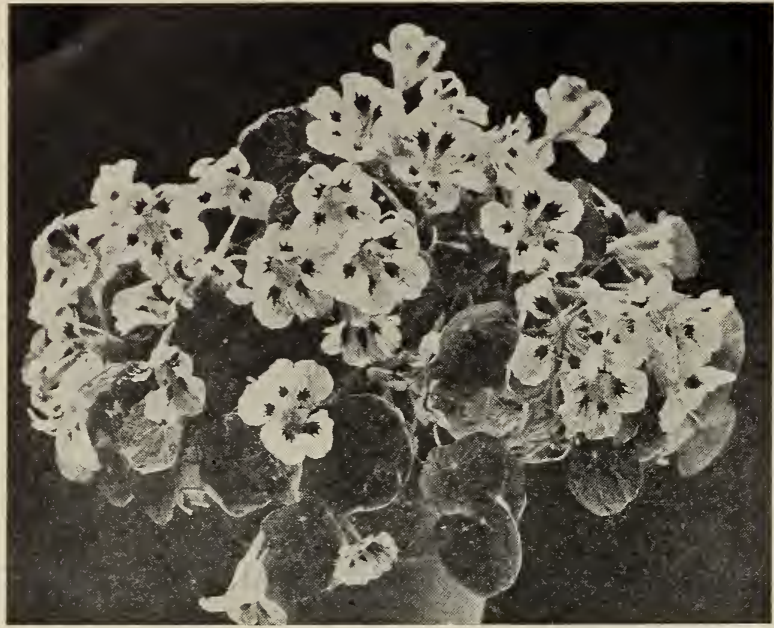

Nasturtium-Crystal Palace Gem

\section{Nasturtium}

\section{DWARF OR BEDDING VARIETIES}

CRYSTAL PALACE GEM. Orange yellow, garnet blotches.

CHAMELEON. A charming variety with variously colored flowers on the same plant.

CLOTH OF GOLD. Yellow foliage, scarlet flowers. EMPRESS OF INDIA. A rich, deep crimson.

GOLDEN KING. Superb golden yellow.

KING OF TOM THUMB. Scarlet with dark foliage.

KING THEODORE. Crimson maroon.

PEARL. Creamy white.

BRONZE. Burnished red.

ROSE. Delicate rose.

VESUVIUS. Rich apricot.

Price of above varieties, each per packet, 10c.

DWARF MIXED. Including all of the above varieties in a well-balanced mixture. Per packet, lic

\section{TALL OR CLIMEING VARIETIES}

CHAMELEON. A charming variety with variously colored flowers on one plant.

DUNNETT'S ORANGE. Pure, rich orange.

GOLD GARNET. Orange yellow withgarnet blotches.

KING THEODORE. Crimson maroon.

ROSE. A splendid selection of this desirable color.

SCARLET. An intense brilliant scarlet.

PEARL. Creamy white.

VESUVIUS. Rich apricot.

RUBY. Bright ruby red.

Price of above varieties, each per packet, 10c.

MIXED. All colors. Per packet, 10c.

\section{Nemesia Strumosa}

MIXED HYBRIDS. A lovely strain of mixed colors of this beautiful South African annual. The strain contains all colors from pale yellow to pink, white, orange, scarlet, etc. Elegant for Spring or Fall bedding. Easily raised from seed.

Per packet, 15c.

\section{PANSIES \\ H. \& S. Special Mixture}

There is no finer strain in existence. The blooms are of enormous size, superb substance and thick velvety texture. Flowers are variously blotched and stained and offer a fine assortment of colors and combination of colors. On well grown plants the flower attains a diameter of three inches and over. This class of Pansy is shy seeding and the seed consequently high in price.

Per packet, 50c.

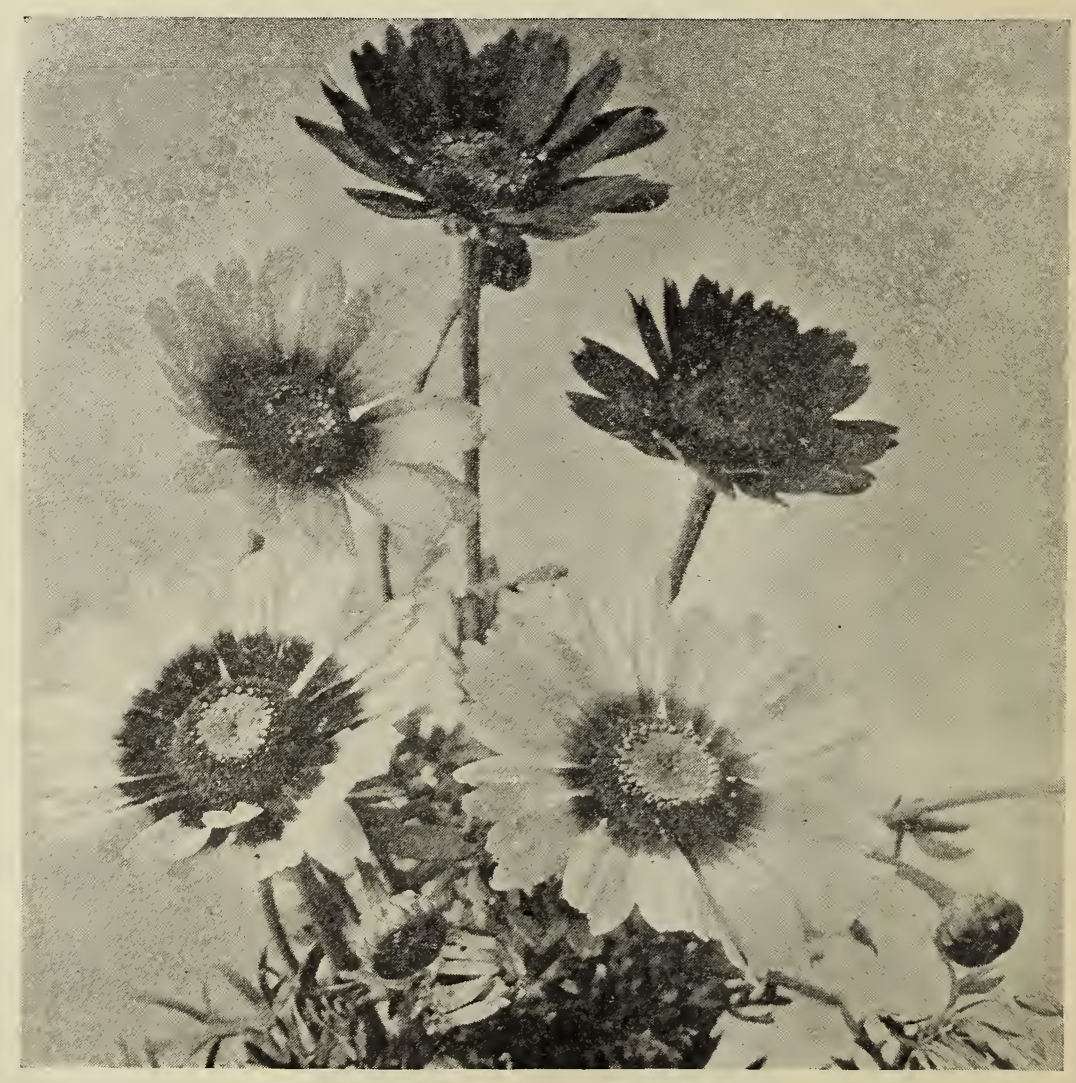

Single Annual Chrysanthemum.

These should be largely planted for cutting purposes. (See page 57.) 


\section{Pansies}

GIANT FRENCH. A lovely strain of giant flowering Pansies running to shades of yellow spotted black, blue on yellow grounds, lavender, purple, etc., all of the flowers being variously blotched. This strain is cuite distinct from our special mixture, but of very high quality. They are comparatively free seeders.

Per packet, 25c.

\section{Petunia}

Petunias are among the most important of all of our Summer flowering annual bedding plants. Splendid displays of color may be obtained with them. They blossom from early Spring until the following Winter and produce an uninterrupted display of color. They will stand extremes of heat and require but little care beyond a bountiful supply of water during very dry weather.

\section{H. \& S. GIANT FRINGED \& RUFFLED MIXED.} A grand strain of single ruffled and fringed Petunias. Blossoms are of mammoth size and splendid substance. Flowers attaining a diameter of five inches are quite common. Excellent for Summer bedding. Per packet, 25c.

\section{Pếunia \\ Five Extra Fine Dwarf Bedding Petunias}

BABY BLUE. A dwarf, compact variety, light blue in color. An excellent bedding variety. Per packet, 15c.

BRILLIANT ROSE. Rich rosy pirk. Belongs to the same class as th varieties Snowball and Rosy Morn. A valuable bedding variety $\mathrm{Per}$ packet $15 \mathrm{c}$.

LORD COURTENAY. A magnifcent shade of deep rich rose, quite distinct from others in this set. A lovely bedding variety.

Per packet, 25c.

ROSY MORN. Soft rosy pink Comes absolutely true from seed. Plant compact. When in bloom a veritable sheet of soft rose pink. Per packet, 15c.

SNOWBALL. Pure white small flowered Petunia in the same class as Rosy Morn. Equally valuable for bedding purposes.

Per packet, 15 c.

\section{New Balcony Petunias}

For parkway planting or solid beds in the garden those small flowered $\mathrm{Pe}$ tunias will give an unbroken display of color throughout the entire season. The flowers are small in size, but lavishly borne. This strain is also of great value for window box work, as the plants are not so compact in habit as those of the preceding class.

BALCONY QUEEN. A brilliant shade of rich carmine. Very fine.

Per packet, 25c.

BALCONY ROSE. A splendid shade of rich rose.

Per packet, 25c.

BALCONY WHITE. Pure snowy white. Per packet, 25c.

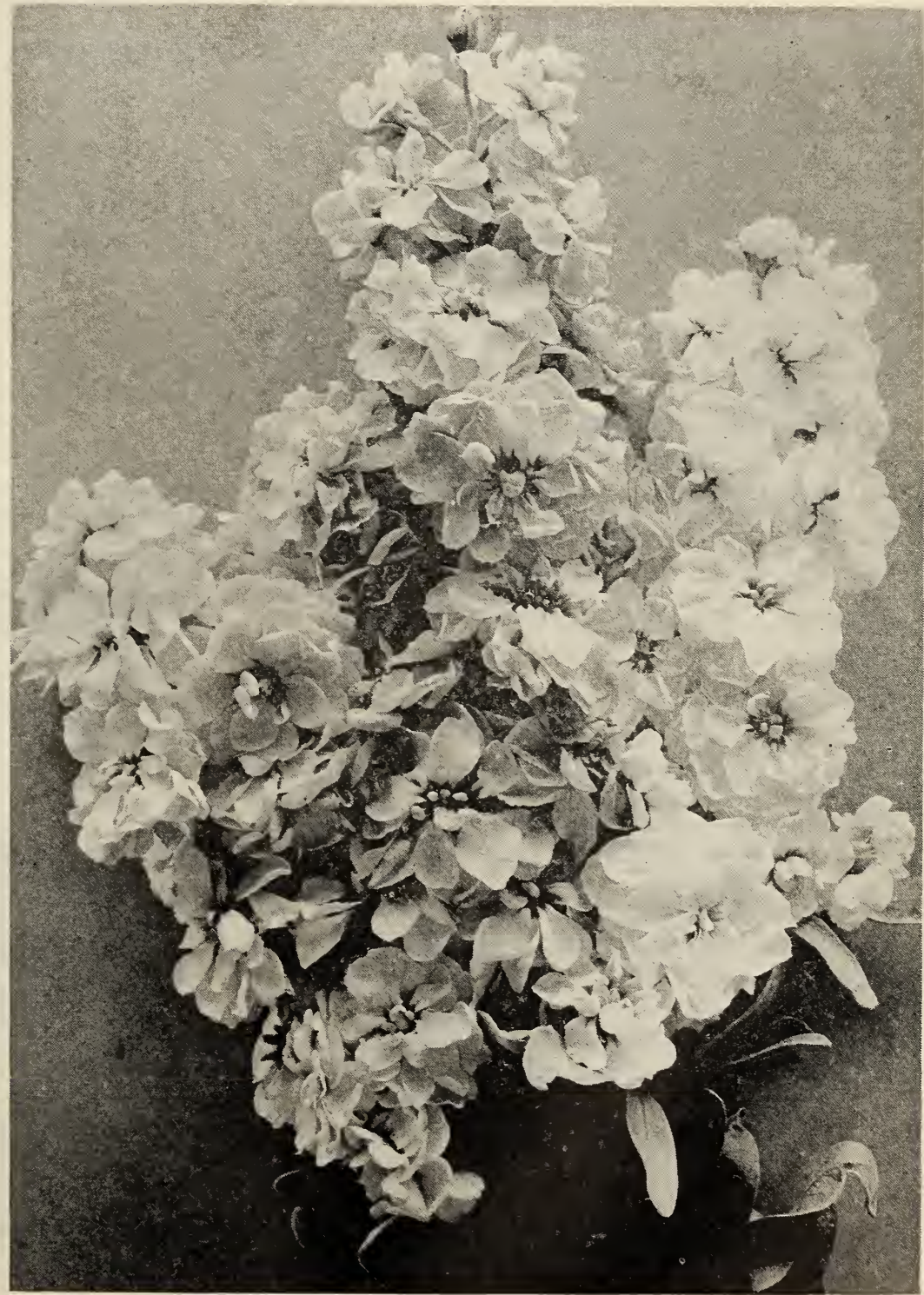

Giant Flowered Stocks Beauty of nice Type (See Page 65) 


\section{POPPY \\ Carnation Flowered}

A splendid strain of Poppies with perfectly double flowers beautifully fringed not unlike in general appearance a giant flowered Carnation. This strain contains all colors from pure white through the various shades of soft pink, rose and red.

Per packet, 15c.

\section{Paeony Flowered}

These are the largest flowered of all the annual species of Poppy. The flowers are of enormous size perfectly double, beautifully fringed with a wide range of colors represented in the strain.

MIXED. All colors.

Per packet, 10c.

\section{POPPY}

\section{Eldorado}

One of the loveliest strains of Poppies ever introduced. They might be regarded as an improvement over those of the Shirley type. The colors to be noted in this strain are charmingly fresh and bright and nothing more beautiful can be conceived than a bed of these Poppies when in full bloom. The color series is one of remarkable beauty. Lovely shades or orange salmon, soft shell pink, orange scarlet, pure white and terra cotta are prominent in this beautiful strain. The flowers occur in both double and semidouble forms. They possess a grace and beauty which will appeal to everyone. For the benefit of our customers who desire definite colors effects, we have made selections which are very fine, of some of the most distinct shades.

PINK SHADES. A superb selection of all of the various shades of pink and rose. Very fine. Per packet, 15c.

SALMON SHADES. Lovely shades of salmon, terra cotta and orange.

Per packet, 15c.

MIXED. All colors including a very high percentage of doubles.

Per packet, 15c.

\section{POPPY}

\section{Iceland Poppy}

\section{NEW SUNBEAM STRAIN}

A lovely new strain of this hardy perennial species. The plants are of dwarf habit and form dense clumps from which issue long stemmed flowers in various shades of pure orange, orange scarlet, lemon, maize and pure white. These Poppies are of great value for cutting purposes and their keeping qualities especially good. Seed sown in Spring will flower during the same year, or they may be sown in Autumn for late Winter and early Spring flowering. This is a strain of exceptional quality.

Per packet, 25c.

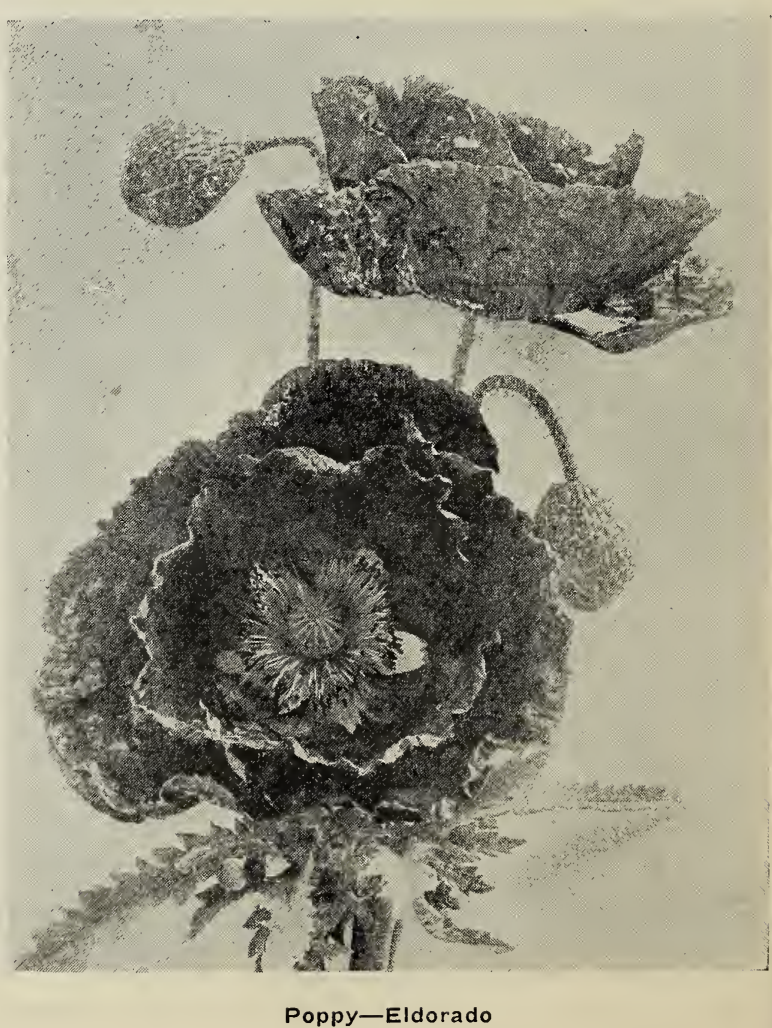




\section{Phlox-Annual}

The flowers of annual Phlox may now be had as large as those of the perennial border species, with even a better and more varied range of colors. Phloxes, as a general thing, withstand much rough treatment. They will grow and bloom freely under the harshest conditions. In gardens where masses of bloom are desired, nothing can equal the display afforded by them.

GRANDIFLORA MIXED. Contains a wide range of colors. An exceedingly choice strain. Height, 12 inches. Per packet, $15 \mathrm{c}$.

NANA COMPACTA FIREBALL. The handsomest dwarf bedding Phlox in existence. Deep red, Height, 8 inches.

Per packet, $15 \mathrm{c}$.

NANA COMPACTA SNOWBALL. Pure white dwarf Phlox. A fine companion to the above. Per packet, 15c.

\section{Portulaca}

A splendid hardy annual which delights in an exposed sunny position, preferably in soils that are somewhat light and welldrained. For parkings, beds, edgings or rock work as a Summer blooming annual Portulacas are admirably adapted. The plants attain a height of some 6 to 8 inches and are prostrate in their habit, similar to a Verbena. They bloom continuously from early Spring until late Autumn and produce vivid sheets of color. Although a simple annual nothing more beautiful can be conceived than a bed of Portulaca at the height of perfection in their blooming season. The seed should be sown where the plants are to bloom. It being quite fine, it is advisable to $\mathrm{mix}$ it with sand and to insure equal distribution in broadcasting it. We offer them in a splendid assortment of colors.

DOUBLE FLESH. Per packet, 15c. DOUBLE SALMON. Per packet, 15c. DOUBLE ROSE. Per packet, 15c. DOUBLE YELLOW. Per packet, 15c. DOUBLE WHITE. Per packet, $15 \mathrm{c}$. DOUBLE SCARLET. Per packet, 15c DOUBLE MIXED. All colors.

Per packet, 15c.

SINGLE BRONZE. Per packet, 15c. SINGLE GOLDEN YELLOW.

Per packet, 15c.

SINGLE ROSE. Per packet, 15c. SINGLE SCARLET. Per packet, 15c. SINGLE WHITE. Per packet, 15c. SINGLE MIXED. Per packet, 15c.

\section{Polyanthus}

There are often referred to as Primroses. They produce immense quantities of brilliantly-colored heads of bloom in early Spring. They are particularly suited for shady borders or may be grown as pot plants for interior or window decoration. Height, 9 to 10 inches.

CHOICE MIXED. Containing a well-balanced mixture of white, yellow, bronze, red, etc. Per packet, 25 c.

Pyrethrum Aureum (Golden Feather)

A well-known plant exceedingly used for edging and carpet bedding. The foliage is bright yellow and fernlike in character. Very easily raised from seed. Height, 6 to 8 inches.

Per packet, 10c.

\section{Ricinus-Castor Oil Bean}

ZANZIBARENSIS. Leaves exceedingly large, stems generally red. The best class for ornamental bedding.

Per packet, 10c.

\section{Scabious \\ Two Splendid Novelties}

PEACH BLOSSOM. A beautiful new variety of ultra refined form and finish. It bears flowers of enormous size perfectly double and will unquestionably prove one of the best varieties of its color for cutting purposes. The color is one of those rich warm shades of rose that lights up especially well under artificial light.

Per packet, 25c.

SHASTA. A splendid companion to the above. One of the finest pure white varieties ever introduced. The color is as pure in tone as driven snow.

Per packet, 25c.

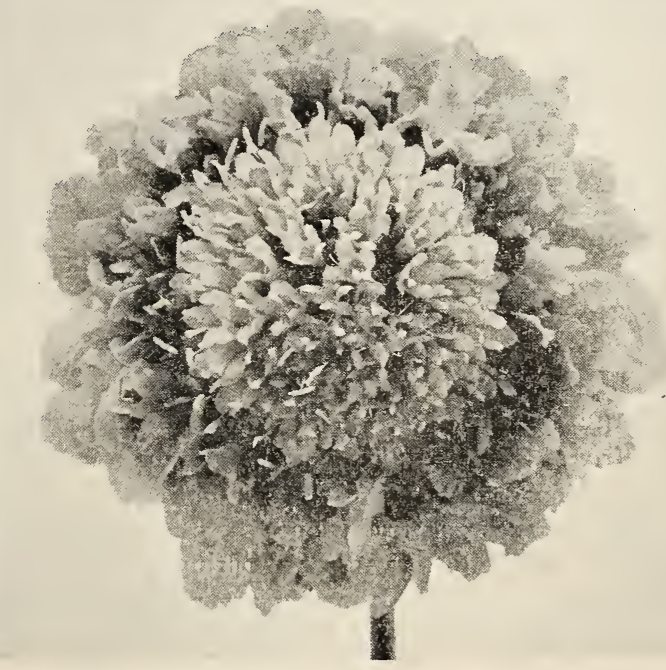




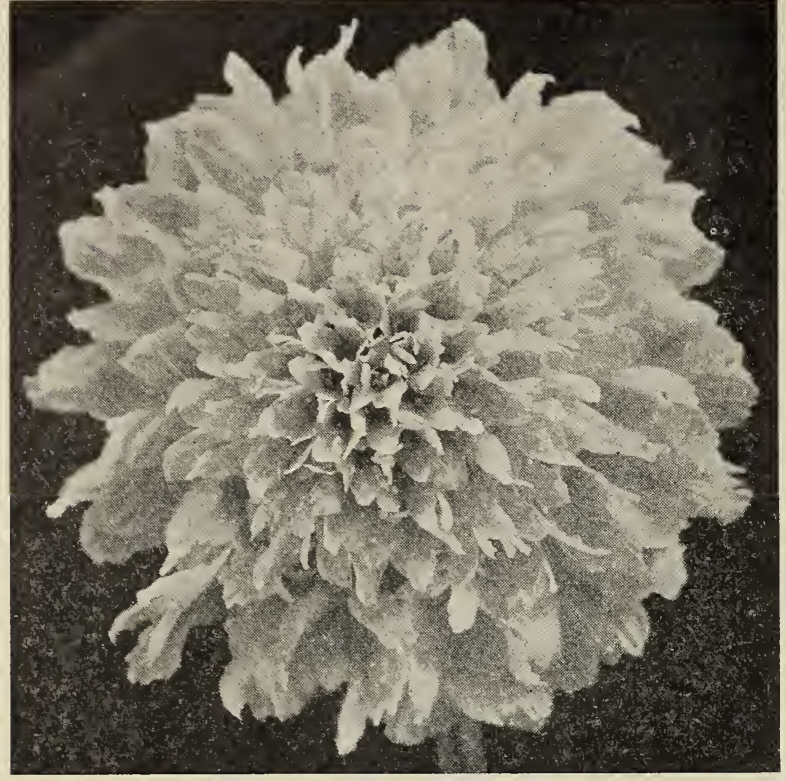

Scabious-Shasta

\section{Scabious \\ New Perennial Hybrids}

A lovely new strain of hybrids of the well-know Caucasica type. The flowers occur in both single and semi-double forms. They are beautifully frilled and offer a color series of matchless beauty. Exquisite shades of sky blue, white, grayish blue, lavender, and dark blue are among the colors to be noted. The flowers are not only large, but there is a grace and delicacy about them which is at once distinct and beautiful. In this section they flower in mid-Winter and right on through Spring. The blossoms are lace-like in their appearance and are of great value for cut flower purposes. Well established clumps of these flower season after season. This strain is one of the most meritorious introductions in perennial plants offered in many a day.

\section{Scabious}

\section{Older Double Varieties in Separate Colors}

The large size and the varied colors of the blooms, ranging from white to pink, cherry red and blue, etc., render Scabious very desirable for bouquets. Seed sown early in boxes and transplanted to the open ground will make a bright display during Spring and Summer. Height, 3 to 4 feet. The following are all beautiful and distinct and should be largely planted.

AZURE FAIRY. A lovely shade of light blue.

Per packet, 15c.

BLACK PRINCE. Deep maroon red, almost black.

DOUBLE CRIMSON. Rich bright crimson.

Per packet, 15c.

DOUBLE WHITE. Splendid double white.

Per packet, 15c.

Per packet, 15 c.

DOUBLE FLESH PINK. A dainty shade of flesh.

Per packet, 15c.

DOUBLE ROSE. Deep rich rose.

Per packet, 15c.

DOUBLE MIXED. An assortment of all colors.

Per packet, 15c.

\section{Salpiglossis}

Among the various free flowering annuals there are but few more easily grown than Salpiglossis. During the past few years a number of fine strains have made their appearance, showing a great improvement both by way of color and size. A bed of these beautiful plants is one of the most striking features in any Summer or Autumn garden. The strain we offer you below represents the acme of perfection to which Salpiglossis have been brought at the present time. The blossoms are gloxinia-shaped in form, with wide open throats. Wi offer them in the following separate colors which are very fine.

BROWN AND GOLD.
LIGHT BLUE AND GOLD.
DARK CRIMSON.
PURPLE AND GOLD.
ROSE AND GOLD.
SCARLET AND GOLD.
VIOLET AND GOLD.
WHITE AND GOLD.
MIXED. All colors.

Per packet, 15c. Per packet, 15 c. Per packet, 15 c. Per packet, 15 c. Per packet, 15 c. Per packet, $15 \mathrm{c}$. Per packet, 15 c. Per packet, 15 c. Per packet, 15c.

\section{Statice}

Aside from the value of Statices as plants for the border, they furnish an abundance of cut flowers which are of great value for mixing with bouquets. The blooms may also be dried and used in Winter bouquets. They retain their color perfectly in a dry state. They do best in a rather sunny location.

CASPIA. One of the best of all various varieties for use in bouquets. Properly cured this variety lasts for an indefinite period, retaining its blue color.

Per packet, 15 c.

PEREZII. This variety is one of the most impressive of all of the various Statice grown. It is a perennial species with handsome broad dark green foliage surmounted by immense branching heads of bright blue flowers. The plant is of striking effect in the garden and immensely valuable as a cut flower for indoor decoration. A wonderfuly effective plant. Per packet, 25c.

SINUATA BLUE.

SINUATA WHITE.

SINUATA MIXED.

The last mentioned Statice sinuata varieties are a distinct class of the annual sea lavender and immensely valuable for mixing in bouquets.

\section{Schizanthus}

One of the prettiest of half-hardy annuals and amenable to a variety of uses. In a climate similar to that of Southern California it makes an ideal bedding plant, 


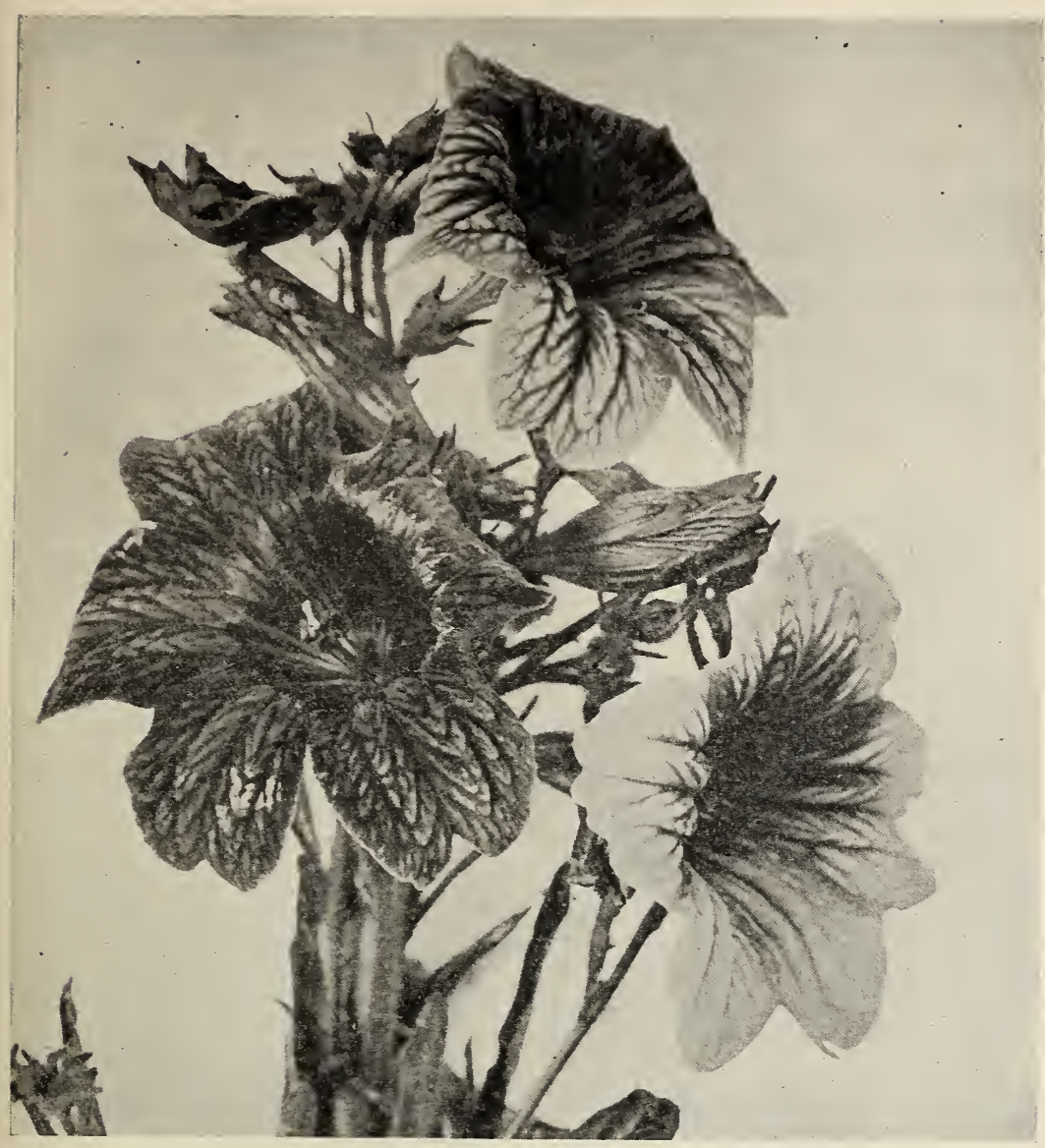

Salpiglossis-Giant Emperor

planted right out in the open. It can be grown in pots in greenhouses and brought into bloom during Winter and Spring when flowers are exceedingly scarce. A single package of seed will produce a large number of plants and furnish an abundant variety of flowers.

WISETONENSIS. Undoubtedly one of the finest strains in existence. Highly improved over ordinary stocks.

\section{Sweet William}

One of the most highly esteemed of all hardy garden plants. They are not only of easy culture, thriving in any garden soil, but produce a wonderful show of color during early Spring. Although the plants last over two seasons, it is generally advisable to make a fresh sowing each Spring for blossoming the following year. Height, 12 inches.

GIANT AURICULA EYED. A elegant strain of these old-fashioned biennials. It is remarkable for the immense size of the individual trusses and blooms. The center of the flowers are pure white zoned with various shades of crimson, pink, rose, etc., at the exterior. This particular selection of Sweet William is of French origin and is unquestionably one of the best which has yet come under our notice. Per packet, 25c.

PINK BEAUTY. Single. Beautiful pure pink.

Per packet, $\mathbf{1 5 c}$.

SCARLET BEAUTY. Bright salmon scarlet. Very fine.

\section{Stocks}

No Spring garden can be considered complete without some of these showy annuals. The seeds we offer are saved from our own giant strains and will produce a high percentage of choice double blooms. It should be borne in mind that stock seed is only saved from the single flowers, as the double flowers are absolutely sterile, the result being that there is always a percentage of singles in even strains of the highest quality. The percentage of doubles varies considerably in the different colors, but fully 60 to 70 per cent of fine double blooms may be depended upon from our seed.

\section{Two Fine Bedding Stocks}

EMPRESS ELIZABETH. A handsome dwarf bedding stock attaining a height of about 15 inches. The compact plants are surmounted by large numbers of fine spikes of blooms, the color a lovely shade of soft silvery rose pink.

Per packet, $\mathbf{1 5 c}$.

WHITE LADY. A splendid companion to the foregoing. Pure snowy white.

Per packet, 15 c.

\section{BEAUTY OF NICE TYPE}

\section{Tall Growing Varieties}

WHITE.

LAVENDER.

DARK BLUE. YELLOW.
BLOOD RED.

MIXED. All colors.
Per packet, 15c.

Per packet, 15c. Per packet, $\mathbf{1 5 c}$. Per packet, 15 c. Per packet, 15c. Per packet, 15 c.

\section{Thalictrum Dipterocarpum}

This handsome herbaceous perennial plant is easily raised from seed. The blossoms are minute in character varying from mauve to deep blue in color, the center of the flower being light yellow. The plants reach a height of six feet and over, and are delicately graceful subjects as seen growing in the garden. Aside from its value as a garden plant the cut sprays lend themselves well in mixed bouquets, giving a light airy effect to the whole.

Per packet, 25c。

\section{Trachelium}

A handsome hardy biennial easily raised from seed. It bears large heads of small bright blue flowers indispensable for cut flower work. The plant does best in a fully exposed sunny position and is covered with its attractive flowers during the late Spring and Summer months. 


\section{H. \& S. Select ed Sweet Peas}

There are but few annual flowers which rival the Sweet Peas in popular favor. With the advent of the orchid-flowered or Spencer type their popularity has increased by leaps and bounds. New shades of color, flowers of elegant form with beautifully waved and crinkled outline are now obtainable. The early type of Sweet Pea known as the grandiflora class with their somewhat stiff appearance have almost entirely disappeared from cultivation giving way to these handsomer and larger improved types. Innumerable varieties have been placed upon the market, so many in fact that it is often be wildering to a purchaser to make the proper selection.

Out of the hundreds of varieties which are available today we have made a selection of those which are representative of the very best with respect to size and color. The varieties offered below in both the early and late flowering section may be regarded as the finest and best Sweet Peas obtainable today. Our seed is put in liberal packages and is absolutely true to name and description.

\section{Early Flowering Varieties}

These Sweet Peas are the latest improvement in this class of annuals. They are an early flowered type and blossom some five to six weeks in advance of late Spencers. For Winter flowering these varieties are without peer.

AMETHYST. Royal purple, a brilliant and telling shade. Per packet, 25c.

ALL WHITE. The best pure white on the market. Exceedingly prolific. Per packet, 25c.

AVIATOR. One of the best of the entire collection-splendid glowing crimson.

Per packet, 25c.

FAIR MAID. An exquisite shade of blush pink.

Per packet, 25c.

GLITTERS. Bright fiery orange. A unique and beautiful shade. Per packet, 25c.

GRENADIER. Dazzling scarlet, one of those fiery reds that radiate warmth and color. Per packet, 25c.

HARMONY. A splendid large flowered true lavender. $\quad$ Per packet, 25c.

MRS. KERR. A lovely tone of salmon coral, distinct from all other varieties. This beautiful Sweet $\mathrm{Pea}$ has created a sensation wherever grown.

Per packet, 25c.

NEW BLUE. A deep lavender blue, very desirable for mixing with lighter shades.

Per packet, 25c.

ROSE CHARM. Bright rose. One of the finest of all rose shades. Per packet, 25c.

ROSE d'OR. A novel shade of rose suffusing under artificial light. Per packet, 25c.

ZVOLNECK'S ROSE. A giant among Sweet Peas. Per packet, 25c.

MIXED. A well-balanced mixture with all of the above. Per packet, 25c.

SPECIAL OFFER. One package of each of the above for

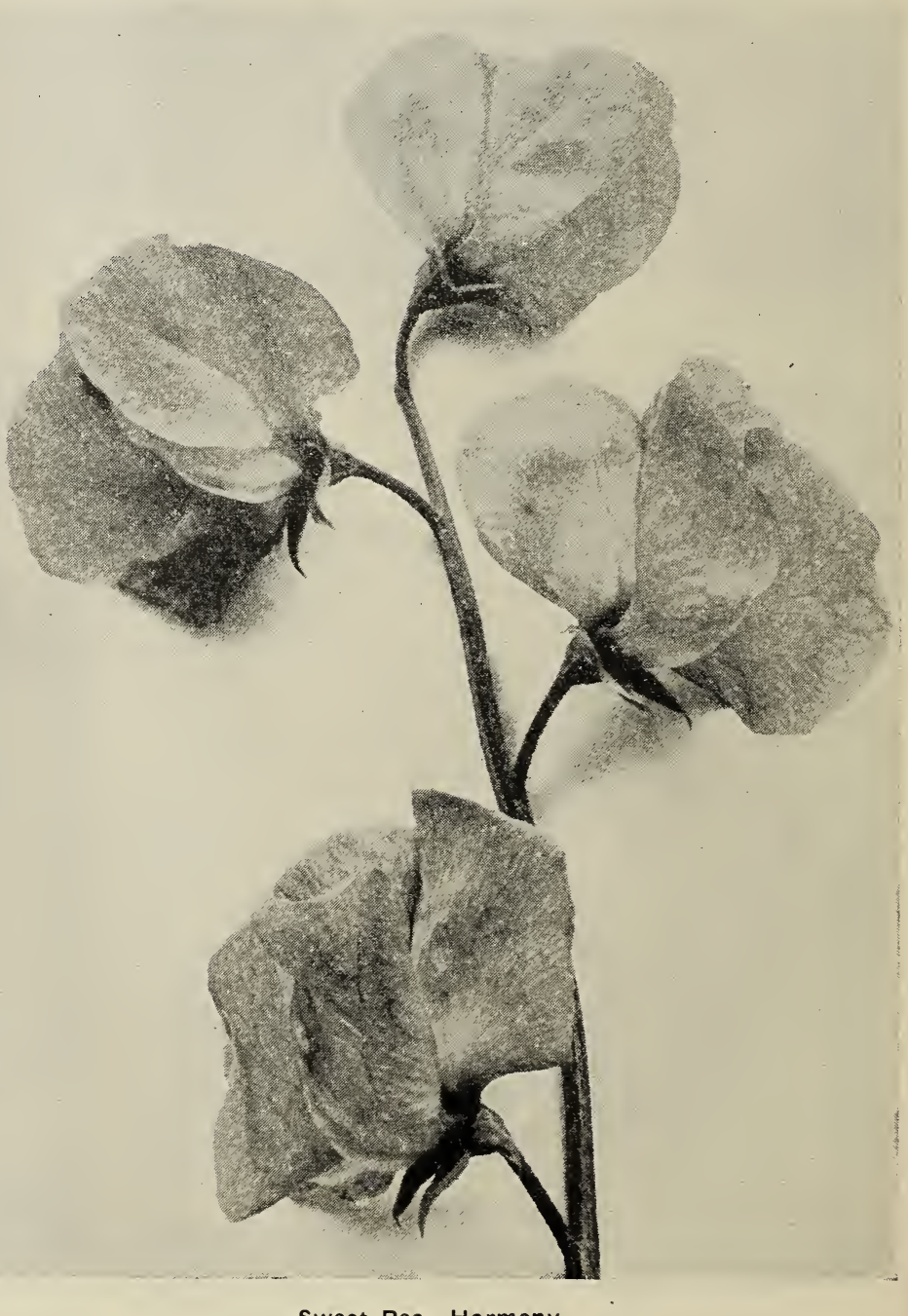

Sweet Pea-Harmony 
ZVOLNECK'S ROSE. A giant among Sweet Peas. This splendid Sweet Pea will be an outstanding variety for many years to come.
Per packet, 25c.
MIXED. A well-balanced mixture containing all of the above.

Per packet, 25c.

SPECIAL OFFER. One package of each of the above 12 named varieties for

$\$ 2.25$.

\section{$\mathrm{H} \& \mathrm{~S}$ Selected Late-blooming Orchid-flowered Sweet Peas}

The varieties offered in the following list are of the true late flowering Spencer or orchidtype of Sweet Peas and represent the latest improvements in Sweet Peas to date. The varieties of this class succeed the early flowering Spencer type in time of blooming and reach maturity about four to five weeks after the former. The flowers are of beautifully crinkled and wavy outline, enormous as to size having a spread of 2 inches or more across the face of the flower. The flowers are usually borne in fours.

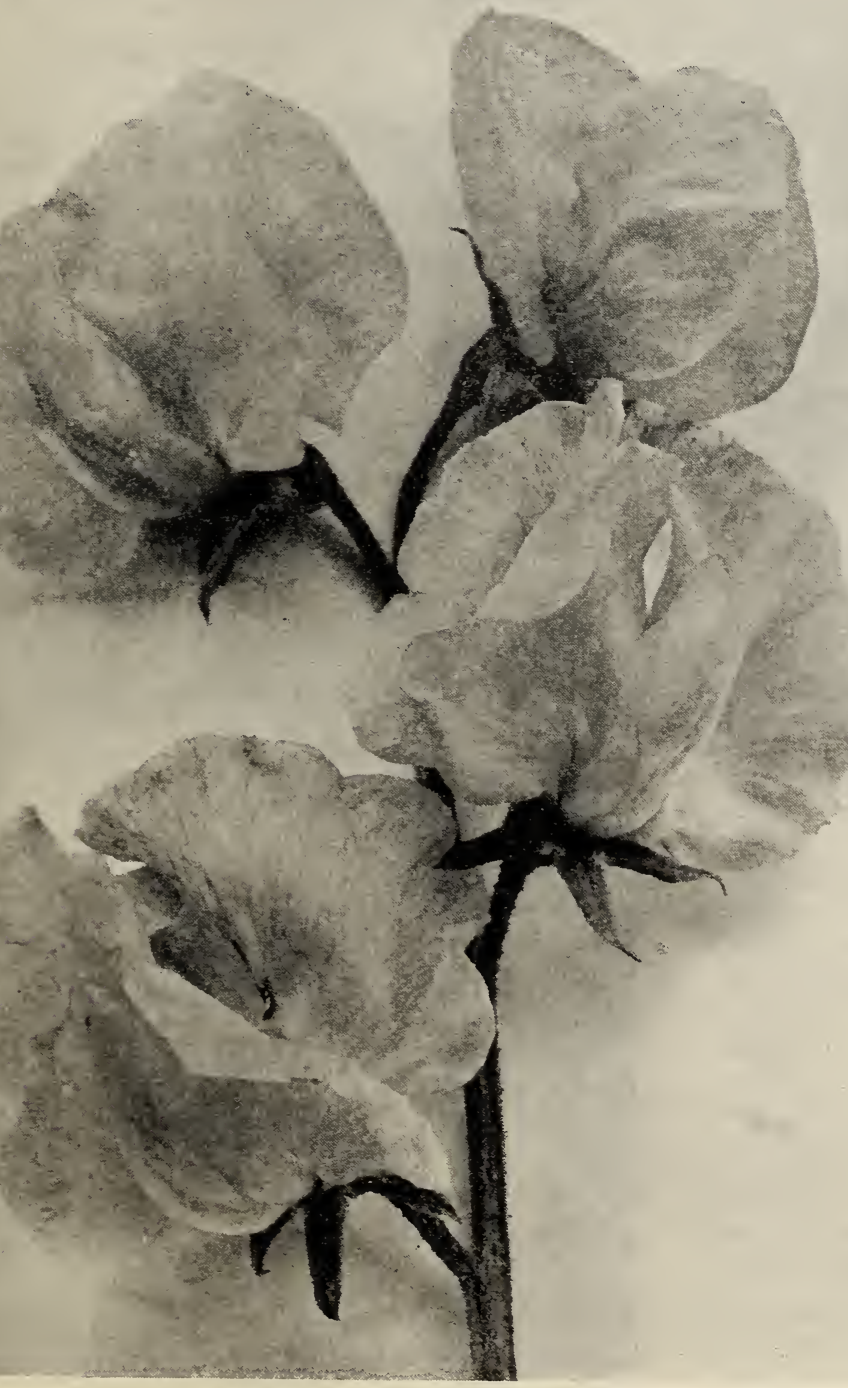

Sweet Pea-Heavenly Blue
CHARITY. Deep rich crimson. Of immense size. Flowers beautifully waved.

Per packet, 25c.

DEFIANCE. A glorious shade of bright orange scarlet. Extra fine.

EDNA MAY IMPROVED. Pure snowy white. An immense flower of refined form and finish. Per packet, 25c.

HAWLMARK PINK. A lovely shade of pure soft pink. Per packet, 25c.

HAWLMARK SCARLET. Rich brilliant scarlet. Flowers of grand size beautifully crinkled. Per packet, 25c.

HEAVENLY BLUE. Superb novelty. An exquisite shade of pure delphinium blue.

Per packet, 25c.

HEBE. An extra large pure bright pink. Superb in size and form.

Per packet, 25c.

MAJESTIC CREAM. A lovely cream colored Spencer sweet pea.

Per packet, zse.

POWERSCOURT. ..An e $x q u$ u i ite shade of pure lavender. Flowers are of remarkable size and of splendid substance.

Per packet, 25c.

TANGERINE IMPROVED. Pure glowing orange. A remarkably fine color.

Per packet, 25c.

WARRIOR. Deep maroon, of pure and even shade. Per packet, 25c

YOUTH. A lovely shade of glowing orange scarlet. Per packet, 25c.

H. \& S. SPECIAL MIXTURE OF LATE FLOWERING SWEET PEAS. A well balanced mixture containing all of the above.

Per packet, 25e.

SPECIAL OFFER. One package each of the above superb late flowering Sweet Peas for \$225. 


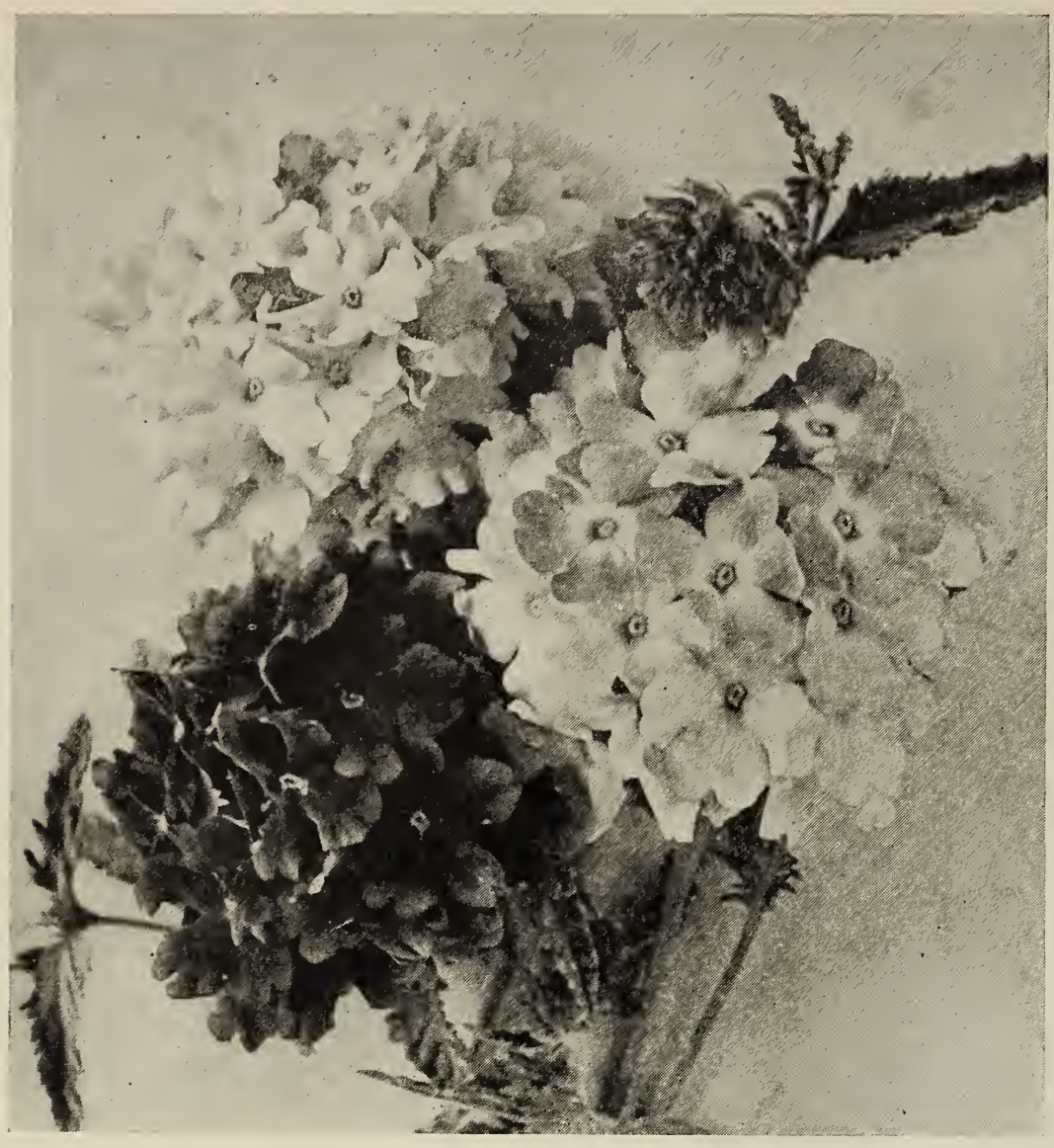

Verbena-H \& S Prize Mixed Giants

\section{Valerian}

Large showy perennial plants, producing large corymbs of red or white flowers. Particularly valuable for the herbaceous borders. They also make good cut flowers. Height, 2 feet.

ALBA. White. Per packet, 10c. RED.

\section{Viola Papilio}

A handsome light blue bedding Viola, a variety which comes nearly true from seed and bears during the Autumn, Winter and Spring months, masses of medium size flowers. Although this Viola is not as large as many Pansies, it more than makes up for its deficiency in this respect by its remarkable production of blooms. From seed sown in July or August, the plants will produce a carpet of flowers from Novem. ber to May.

Per packet, 25c.

\section{Wallflowers}

New early flowering varieties which can be treated as annuals. If sown early in seed beds, will bloom freely during the coming Summer and Autumn.

EARLY PARIS MARKET. Light brown.

Per packet, 15 c.

GOLDEN GEM. Bright golden yellow.

BLOOD RED.
Per packet, 15c.

Per packet, $15 c$.

\section{Verbena}

We call your attention to the unusually high quality to be noted in our prize strain of these old-fashioned popular plants and do not hesitate to say it is one of the best procurable. It contains not only a wide range of colors, but it is remarkable for the mammoth character of both the individual blossoms and trusses. Verbenas are easily grown from seed, flowering within a comparatively short time and giving an unbroken succession of flowers right through Summer and Autumn.

HOWARD \& SMITH PRIZE MIXED. The strain which we offer you is our own and from which we have raised such varieties as Crimson King, Scarlet Queen, etc. The trusses and individual florets are of immense size and contain a wide range of colors, including all shades from purest white to darkest crimson, with the intervening shades of pink, purple, rose, lilac, lavender, etc. For mixed bedding these Verbenas are of exceptional merit. Extra choice.

Per packet, 25c.

LUCIFER. Uniform bright scarlet of a rich and glowing nature. An elegant bedding effect may be obtained with this Verbena. As brilliant in color as some of the deeper colored geraniums.

Per packet, 25c.

COCCINEA. A lovely bedding Verbena of the small flowered type which comes uniformly true from seed. The trusses are freely produced, the plants neat and compact in habit.

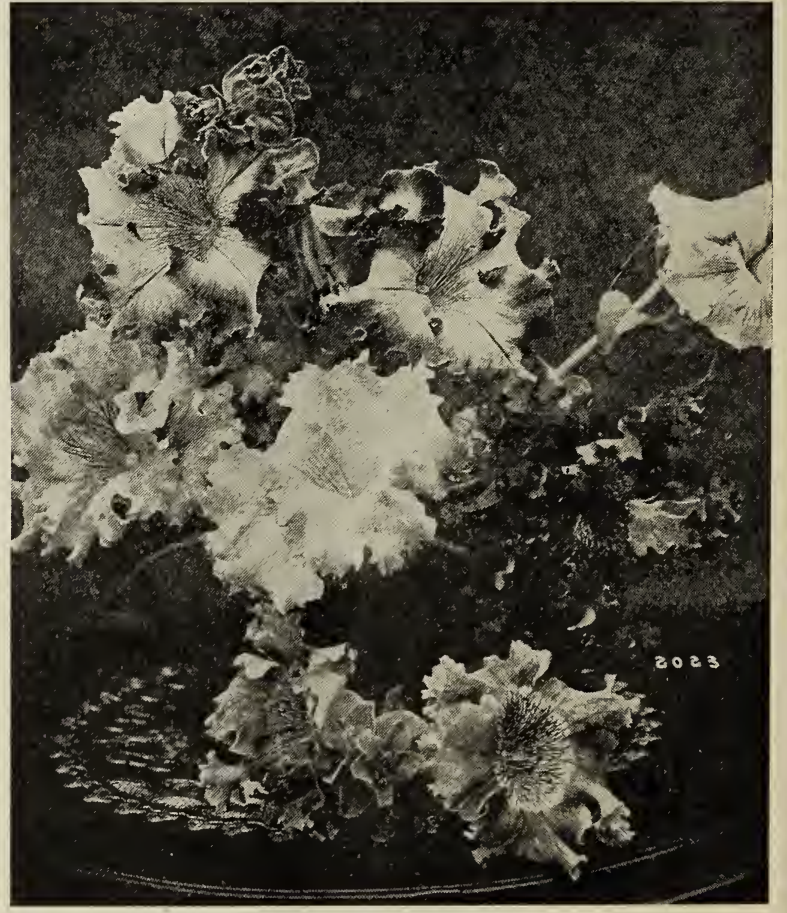

Petunia-Giant ruffled and fringed Hybrids 
A grand new strain of giant flowered Zinnias bearing flowers which are simply enormous as to size. Fully developed blossoms reach a diameter of 6 inches and over. The plants are well branched, of sturdy growth, and blossom without intermission from early Summer to late Autumn. They are invaluable for cutting purposes or for bright stretches of color in the garden. We direct our customers' attention to the fact that all the seed offered in the separate colors has been grown in blocks and carefully rogued as to type and color, but certain variations are bound to appear even though the greatest care is used. Any color variations, however, which might show in this seed, will be in flowers of the same type, differing only in color, but equally as valuable for cutting.

\section{Five Magnificent Dahlia Flower-} ed Zinnias

CANARY BIRD. Bright canary yellow; otherwise similar in all respects to Golden State.

\section{CRIMSON MON-} ARCH. A particularly bright and pleasing shade of chestnut crimson. A selection which bears flowers of mammoth proportions. Extra fine. Per packet, 25c.

EXQUISITE. A superb variety any way you take it, and all that its name implies. Color in the opening flowers a wonderful shade of bright Tyrian rose.

Per packet, 25c.

GOLDEN STATE. Dark orange with a deeper colored center. Somewhat similar to Oriole in color, but the general effect of a bed is lighter in tone.

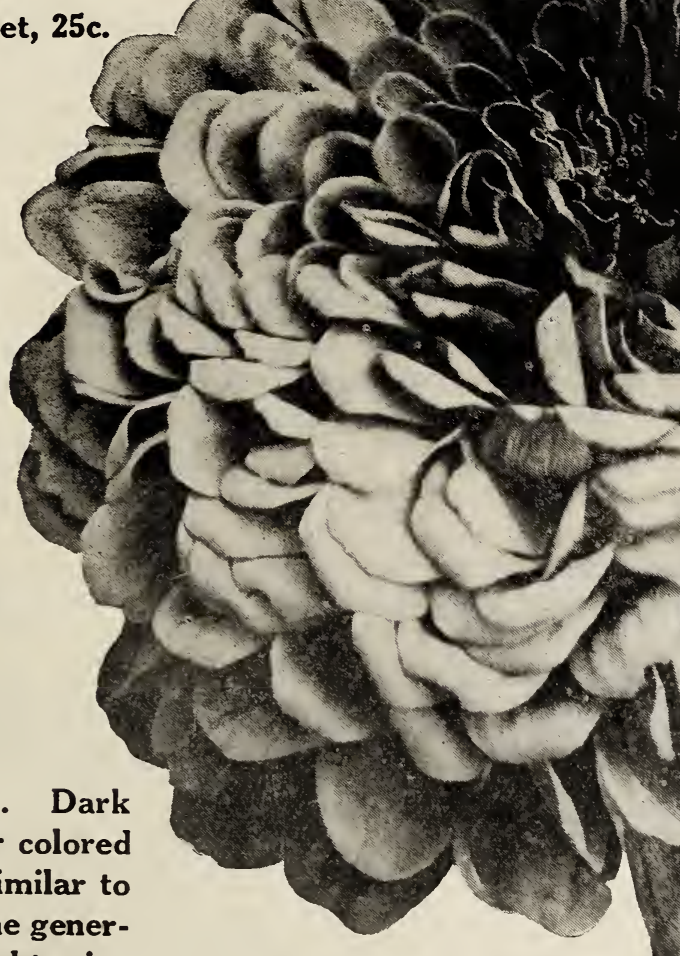

Per packet, 25c.

ORIOLE. A magnificent shade of tawny orange with the center of the flower a deeper shade. A replica of Exquisite as to size. This variety is well fixed.....A superb variety.

Per packet, 25c.

MIXED. The colors contained in this mixture comprise all of the above varieties as well as others which are not yet sufficiently fixed to offer them under separate shades. They will prove highly satisfactory where a variety of color is desired and make a handsome showing.

SPECIAL OFFER. One package each of the above five named Giant Dahlia Flowe.ed Zinnias, a grand assortment for

$\$ 1.00$.

H \& S New Pastel Shades

An especially fine selection in the giant flowered type of Zinnias which we are able to offer our customers this season in a highly perfected form. The strain is replete with exquisite shades of salmon rose, bright pink, burnt orange, cerise, etc, with a marked absence of objectionable shades of purple, magenta, etc. The blossoms are models as to form, the delicate colors obtainable gives them special value for cut flower purposes. Per packet, 25c. 


\section{Zinnias \\ H. \& S. Prize Giant Zinnia (Plenissima Type)}

The flowers in the following varieties are of enormous size, but instead of being incurved, as is the case with the Dahlia flowered class, the petals are beautifully reffexed and overlapping. They are models as to form. The colors are particularly rich and distinct.

HOWARD \& SMITH PRIZE SCARLET. Rich glowing scarlet.

HOWARD \& SMITH PRIZE CRIMSON. Bright rich crimson.

HOWARD \& SMITH PRIZE SULPHUR YELLOW. A dainty shade of light yellow.

HOWARD \& SMITH PINK SHADES. Containing shades of rose, salmon and vink.

HOWARD \& SMITH PRIZE GOLDEN YELLOW. A vivid shade of deep rich yellow.

HOWARD \& SMITH PRIZE WHITE. Pure white.

SPECIAI OFFER. One each of the above varieties, which will produce a veritable wealth of beauty and color, for $75 c$.

\section{Unsolicited Testimonials}

No better recommendation of the high quality of our various strains of Asters, Zinnias and other subjects can be given than by the voluntary expressed approval of those who have grown them. Each season we are the recipients of hundreds of these commendations bespeaking high quality of our seeds. We are always glad to have you write us giving us a frank expression of your opinion.

\section{Gentlemen :}

Please accept my thanks in your remembering to send me the dahlia and zinnia seeds. I have grown your zinnias and know the fine quality of the seed. They make wonderful cut flowers-big and nice long stems. Had the pastel shades last year and every one raved over them. But your asters take the prize. Finest thing I can grow.

Very truly yours,

O. W. BERGER, Petaluma, Calif.

\section{Gentlemen :}

You may be interested to know that your Aster Peach blossom won the silver cup at the Brockton Fair last October. The Fair runs for five days average attendance 50,000 daily. The exhibit was a large fancy basket containing 60 to 75 blooms, size 4 to 5 in. stems 18 to 27 in. long.

Yours respectfully,

DAVID TYNDALL, Brockton, Mass.

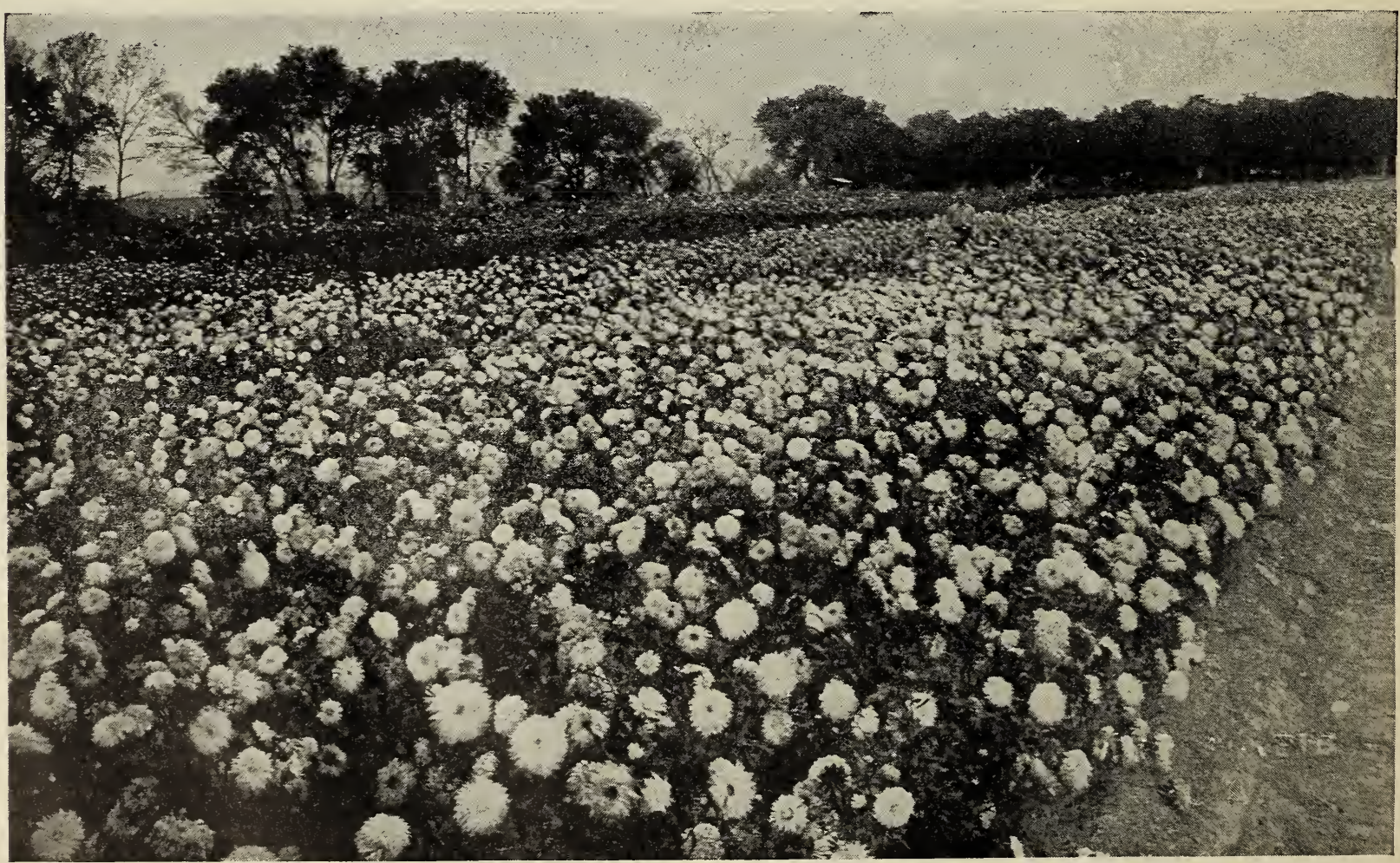


INDEX

\section{PLANTS AND BULBS}

\begin{tabular}{|c|c|}
\hline $\begin{array}{r}\text { Page } \\
\ldots . .37\end{array}$ & Dahlias Pompon ........ \\
\hline 31 & Dahlias Show ................ \\
\hline 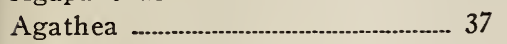 & Delphinium .... \\
\hline Ageratum ..._. 37 & Erigeron $\ldots$ \\
\hline Amarcrinum Howardii ................. 32 & Fuchsias ........ \\
\hline 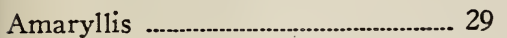 & Gaillardia ....... \\
\hline nchusa & Gazania ....... \\
\hline 1emone & Geraniums ... \\
\hline Aquilegia & Gerbera ....... \\
\hline Armeria …_. & Gladiolus ..... \\
\hline sters & Gloxinias \\
\hline Begonias & Golden Rod \\
\hline Calla Lily ................. & Gypsophila . \\
\hline Cannas-new ............... & Helenium ...... \\
\hline Cannas general coll................ 19 & Helianthus ... \\
\hline Canterbury Bells & Heliotrope ... \\
\hline Carnations & Hemerocallis \\
\hline Chaenostoma & Hollyhocks ... \\
\hline Chrysanthemums Anemone fl....... 14 & Hydrangeas \\
\hline Chrysanthemums Jap & Hypericum \\
\hline Chrysanthemums Nov & Iris ................... \\
\hline Chrysanthemums Pompon.........15-16 & Ismene \\
\hline Coreopsis & Jacobinia \\
\hline Cuphea & Lantana. \\
\hline Cyclamen & Leonotus \\
\hline Dahlias large flowere & 44 \\
\hline Dahlias novelties ..... & 46 \\
\hline Dahlias .......................... & Lopezia \\
\hline 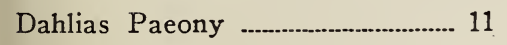 & Lycoris \\
\hline
\end{tabular}

Marguerites Page

Montbretias ........................................ 36

Oriental Poppies ................-..-.... 46

Papaver Orientale ............-................... 46

Pelargoniums ....................................... 28

Penstemons ..................................... 45

Petunias ....................................46-47

Pinks ... ........................................... 47

Plumbago ..................................-.............. 48

Primula ……................................... 48

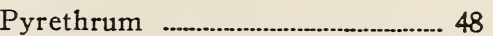

Rudbeckia ..._............................. 48

Russelia .................................... 48

Salvia ................................... 48

Scabiosa …_......................................... 50

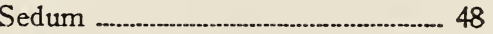

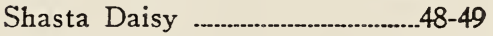

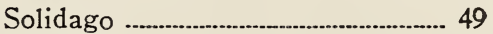

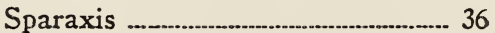

Statice ................................................... 51

Sternbergia …_- 36

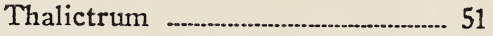

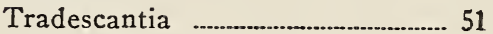

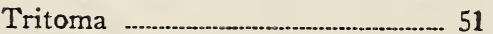

Tuberoses …....................................... 36

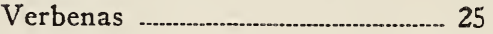

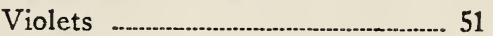

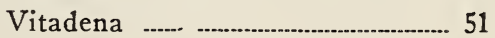

\section{CHOICE FLOWER SEEDS}

Acroclinium ............................. 52

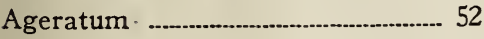

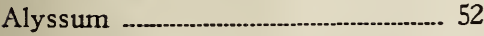

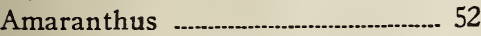

Anchusa ....................-.............. 52

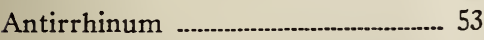

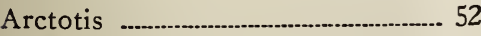

Aster ……-1..-1..-

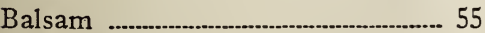

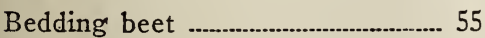

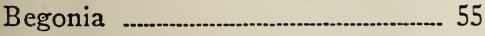

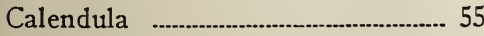

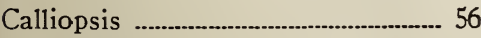

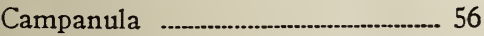

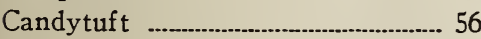

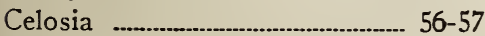

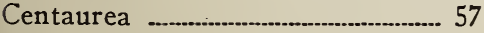

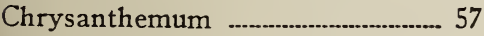

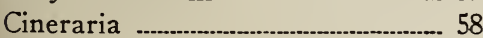

Clarkia ........._-_.

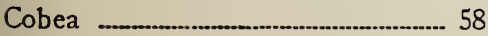

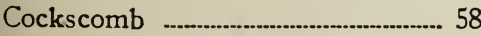

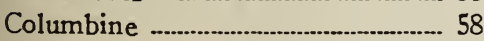

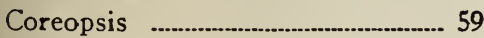

Cosmos ............................................. 59

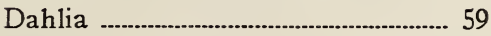

Daisies ..........-. 59

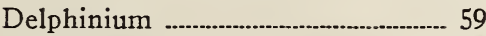

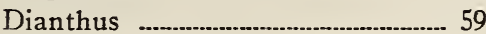

Diascea ........................................... 60

Digitalis ................................................ 60

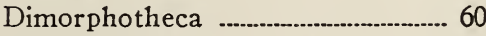

Eschscholtzia …............................ 60

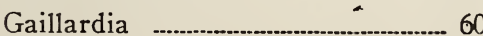

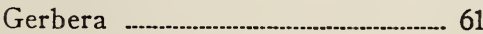

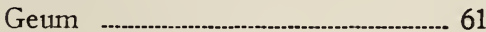

Godetias ......................................... 61

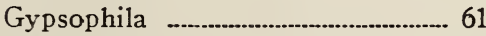

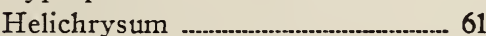

Heliopsis ......................................... 61

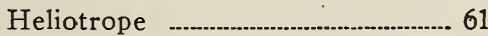

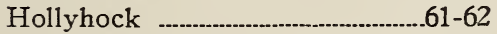

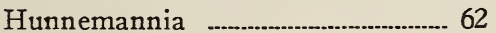

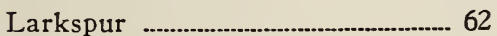

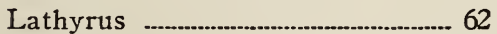

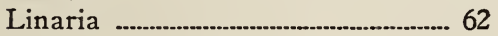

Linum .................................... 62

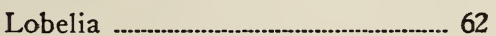

Marigold ........................................ 63

Mexican Poppy .............................. 62

Mignonette ........................................ 63

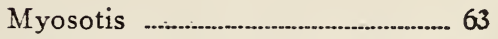

Nasturtiums ...........................63-64

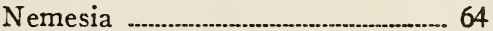

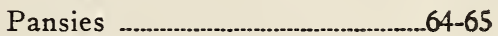

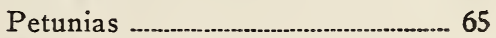

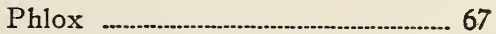

Polyanthus ......................................... 67

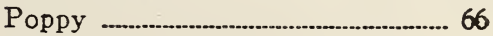

Portulaca …………………-..... 67

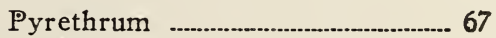

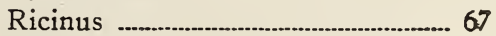

Salpiglossis _..._._._._.

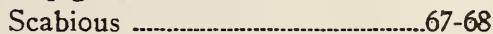

Schizanthus ……-

Statice ........................................ 68

Stocks ............................................ 69

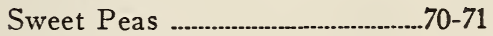

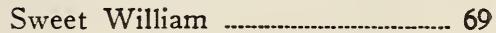

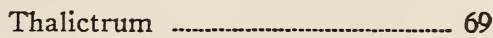

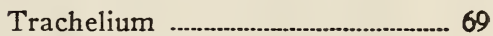

Valerian ................................................... 72

Verbena ...................................... 72

Viola ................................... 72

Wallflowers …………….................. 72

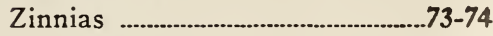


